UNIVERSIDADE DE SÃO PAULO

FACULDADE DE FILOSOFIA, LETRAS E CIÊNCIAS HUMANAS

DEPARTAMENTO DE LETRAS CLÁSSICAS E VERNÁCULAS

PROGRAMA DE PÓS-GRADUAÇÃO EM FILOLOGIA E LÍNGUA PORTUGUESA

\title{
DISCURSO E COTIDIANO: HISTÓRIAS DE VIDA EM DEPOIMENTOS DE PANTANEIROS
}

\author{
Maria Leda Pinto
}

Tese apresentada ao Programa de Pós-Graduação em Filologia e Língua Portuguesa, do Departamento de Letras Clássicas e Vernáculas da Faculdade de Filosofia, Letras e Ciências Humanas da Universidade de São Paulo, para obtenção do título de Doutor em Letras.

Orientadora: Prof ${ }^{a}$ Dr ${ }^{a}$ Helena Hatsue Nagamine Brandão 
A minha querida mãe, Angelina, incentivadora incondicional e exemplo de força e determinação.

Ao meu pai (in memoriam) por tudo que significou em minha vida. 


\section{PRE - TEXTO}

Que as minhas palavras não caiam de Louvamentos à exuberância do Pantanal.

Que eu não descambe para o adjetival.

Que o meu texto seja amparado de

substantivos. Substantivos verbais.

Quisera apenas dar sentido literário

aos pássaros, ao sol, às águas e aos seres

quisera humanizar de mim as paisagens.

Mas por quê aceitei o desafio de glosar

esta obra exuberante de Deus?

Aceitei para botar em prova minha linguagem

Que eu possa cumprir esta tarefa sem

que o meu texto seja engolido pelo cenário

(Manoel de Barros, Para enconrtar o azul eu uso pássaros, 1999) 


\section{AGRADECIMENTOS}

\section{$\mathrm{Na}$ interlocução que resultou neste trabalho muitas foram as vozes, os espaços, os ombros amigos e a palavra é OBRIGADA...}

a Deus, pois sem Ele, nada disso seria possível;

aos meus familiares - minha mãe, minha irmã e meu irmão, minha cunhada e meu cunhado-que souberam compreender os meus momentos de recolhimento devido às exigências deste trabalho e estiveram sempre presentes dando-me incentivo e apoio;

à Prof ${ }^{a}$. Dr ${ }^{a}$. Helena Hatsue Nagamine Brandão pela competência e profissionalismo, pelos conhecimentos partilhados e pelo companheirismo e estímulo na orientação desta pesquisa.Com ela muito aprendi. Valeu!

à Porf ${ }^{a}$ Dr $^{a}$ Dieli Vesaro Palma pelas contribuições valiosas partilhadas no Exame de Qualificação;

ao Prof. Dr. João Wanderley Geraldi pela importante contribuição no Exame de Qualificação, pela amizade e a disposição, sempre pronta, em partilhar seus conhecimentos.Com ele aprendemos sempre;

aos meus sobrinhos que, de maneira muito próxima, viveram comigo a construção desta pesquisa: a Vanusa e a Fabiane que me acolheram em São Paulo, cedendo-me o espaço e dando-me todo o apoio; a Cleise que me apoiou, cedendo seu apartamento para que eu pudesse estudar e escrever com tranqüilidade; ao Tércio, que esteve junto comigo nos momentos cruciais de formatação e finalização do trabalho, incentivando sempre; A Suene e ao Eli, ao Marcos e ao Edgar e Eliana pelas orações e torcida.

aos meus colegas do curso, na USP, pela interlocução em cada encontro, em especial, às amigas, que conquistei no doutorado, Ana $M^{a}$. B. Yasuda e Livia Brandão, interlocutoras pacientes que, com suas sugestões, muito contribuíram para a construção desta Tese;

aos peões pantaneiros que aceitaram contar-me suas histórias de vida, pela disponibilidade e o desprendimento com que tornaram possível a realização desta pesquisa;

aos amigos e amigas que me incentivaram no percurso, especialmente às amigas $e$ companheiras de trabalho Leia Lacerda, Albana Nogueira, Gláucia Lara, Maria Emília Daniel e ao meu amigo José Genésio Fernandes, pela valiosa contribuição na construção da pesquisa e pelo incentivo e apoio;

às minhas coordenadoras-amigas, professoras Rosa Maria C. N. Albuquerque, Celi Correa Neres e Márcia Cristina R. Figliolini pelo apoio demonstrado;

à FMB - Fundação Manoel de Barros - pela bolsa concedida, a qual foi crucial para a realização do trabalho;

à UNIDERP e UEMS, pela contribuição financeira e de tempo para minha capacitação. 


\section{SUMÁRIO}

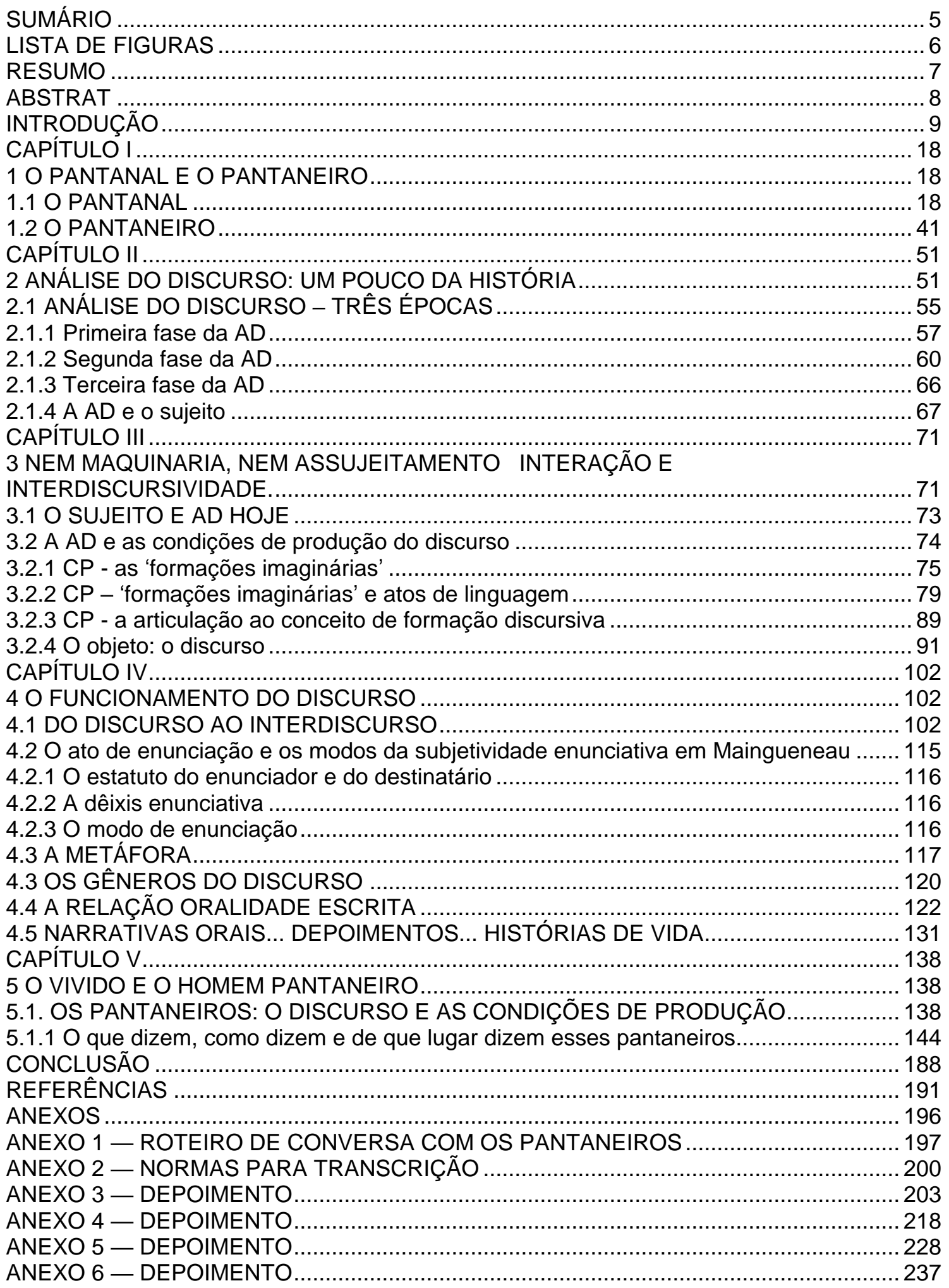




\section{LISTA DE FIGURAS}

Figura 01 - O Pantanal na América do Sul-Brasil, Bolívia e Paraguai ................... 19

Figura 02 - O Pantanal no Brasil-Mato Grosso do Sul e Mato grosso ................... 20

Figura 03 - Bacia doAlto Pantanal ................................................................ 20

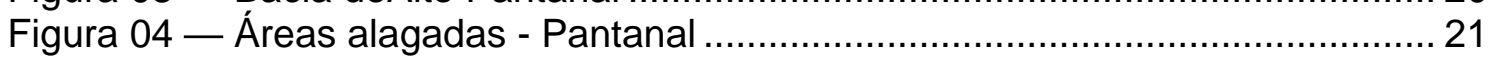

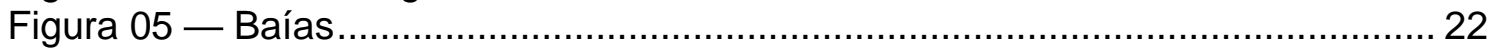

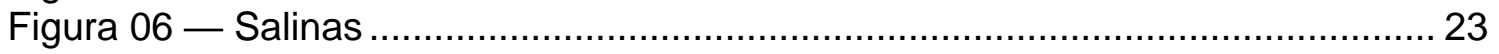

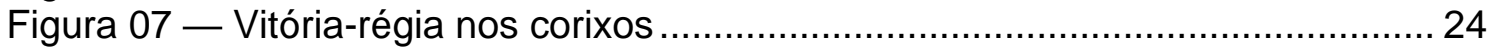

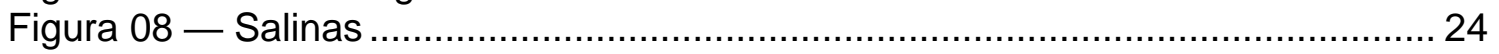

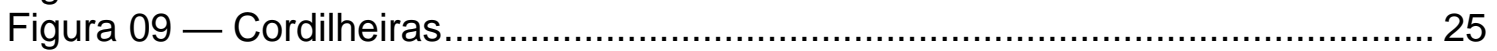

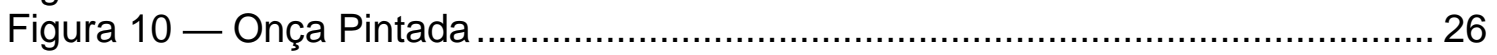

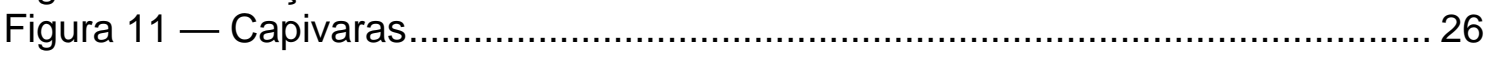

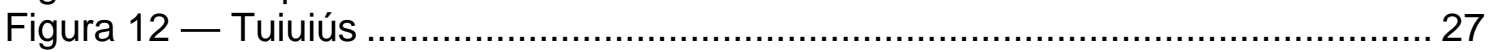

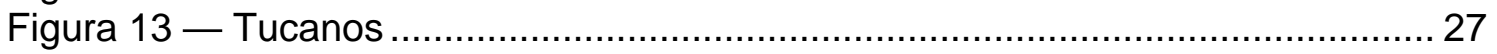

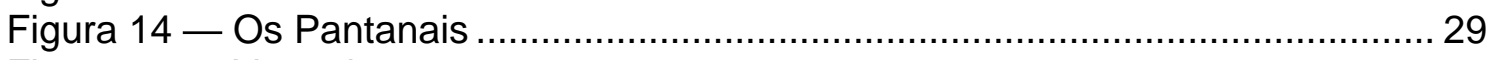

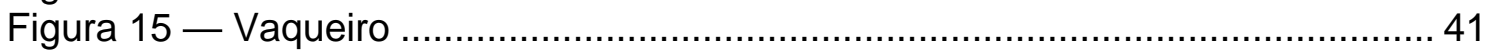

Figura 16 - Sede da Fazenda Santana - Município de Aquidauana - MS ............ 43

Figura 17 - Sede da Fazenda Dois Irmãos - Município de Corumbá -MS ............. 44

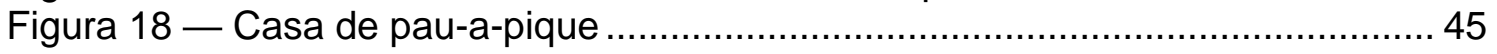

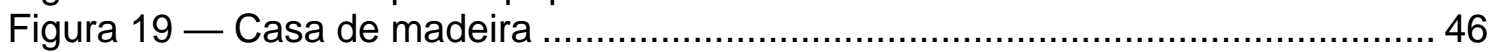

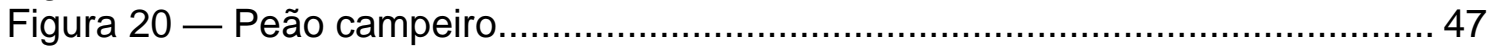

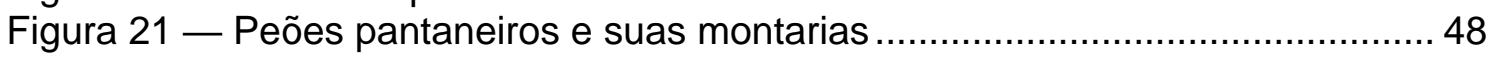




\section{RESUMO}

Esta pesquisa tem por objetivo buscar nas histórias de vida dos pantaneiros a imagem discursivamente construída do homem pantaneiro. É através do uso da língua, aliado a outros aspectos do contexto social em que vive e atua, que 0 homem constitui-se como sujeito que estabelece vínculos sociais com outros sujeitos e com outras culturas, construindo dessa forma, a sua história. O pantaneiro, vivendo do trabalho no Pantanal sul-mato-grossense, região com características geográficas e sócio-históricas singulares, constitui-se, histórica e socialmente, por meio da riqueza lingüística que se concretiza na convivência com outros falantes do português e com os do espanhol e do guarani, línguas presentes na interação discursiva do dia-a-dia, resultantes do convívio, em regime de fronteira aberta, com o Paraguai e a Bolívia. Dessa perspectiva, a questão que se coloca é: em que medida se constrói a imagem do pantaneiro através de seu próprio discurso? Ou, mais especificamente, em que medida é possível evidenciar as imagens do pantaneiro construídas pelo discurso oral do próprio pantaneiro? Diante dessas indagações, o desafio é estudar o discurso do homem pantaneiro, tendo como fundamento teórico a Análise do Discurso, dita de linha francesa, em particular a interdiscursividade que remete a noções como heterogeneidade discursiva, sujeito e as condições de produção do discurso. Esses aspectos teóricos são pensados a partir de três eixos que dizem respeito ao sujeito e suas ações: eixo das ações que se realizam com a linguagem, eixo das ações que se realizam sobre a linguagem e eixo das ações da linguagem. $O$ capítulo 1 deste trabalho apresenta uma contextualização do Pantanal em seus aspectos geográfico, histórico e social. O capítulo 2 traz um breve histórico da $A D$ e do sujeito nesse percurso. O capítulo 3 trata da $A D$ em sua fase contemporânea, pontuando a questão do discurso, do interdiscurso, do sujeito e as condições de produção do discurso. O capítulo 4 apresenta uma breve retomada do percurso da oralidade, dos gêneros do discurso e dos gêneros histórias de vida e depoimento que compõem o título desta tese. $O$ capítulo 5 apresenta a análise das quatro histórias de vida dos pantaneiros selecionadas para este trabalho.

PALAVRAS-CHAVE: análise do discurso, interdiscurso, sujeito, condições de produção, histórias de vida. 


\section{ABSTRAT}

This research's aim is to look for in the pantaneiros (People who live in the Pantanal region) life history, the image that was discursively built of the panateiro man. It is through the use of language plus other aspects from the social context where they live and work that the man forms a subject that keeps social contacts with other subjects and other cultures, building this way, the history. The pantaneiro, living from the work in the south-mato-grossense Pantanal, which region has its own geographic and social historic features, composes, historic and socially, through the linguistic wealth that becomes true while living with other Portuguese speakers and with the Spanish and Guarani ones, languages presented in the discursive interaction day by day, which are resulted from the feast in open boundaries with Paraguay and Bolivia. From this perspective, the question that is presented is: in which level the pantaneiro image is built through its own speech? Or more specific, in which level it is possible to evidence the pantaneiro images built by its own oral speech? Considering these issues the challenge is to study the pantaneiro man speech, by the speech analyses, interdiscursive which remits to notions as discourse heterogeneity, subject and the production conditions discourse, these theoretic aspects are considered from three axles that are related to the subject and its actions: actions axles that are realized with the language, actions axles that are realized about and actions axles of language. Chapter 1 of this research shows a Pantanal contextualization in its geographic, historical and social aspects. Chapter 2 brings a brief historic of DA and the subject in its course. Chapter 3 talks about the DA in its comtemporary phase, showing the discourse issue of the interdiscourse, the subject and is production conditions discourse. Chapter 4 shows a brief retaking of the oral part, of the discourse genres and life histories genres and deposition that composes this research's tittle. Chapter 5 shows the analyses of four life histories from the pantaneiros selected for this work.

KEYWORDS: discourse analyses, interdiscourse, subject, production conditions, life histories. 


\section{INTRODUÇÃO}

O nosso interesse em estudar o discurso e o cotidiano do homem pantaneiro se deve, primeiramente, ao fato de que a identidade desse sujeito vista numa perspectiva discursiva é, do nosso ponto de vista, extremamente rica. Existe um vasto material que enfoca o Pantanal em sua diversidade, como espaço singular considerado a maior reserva ecológica do mundo, entretanto, até onde me foi possível constatar, não foi realizado, até o momento, nenhum trabalho científico tomando por objeto de estudo a imagem do sujeito pantaneiro nos discursos, numa perspectiva da Análise do Discurso.

Diante desses aspectos, lançamo-nos no desafio de estudar o discurso do homem pantaneiro, tendo como fundamento teórico a Análise do Discurso, dita de linha francesa. Julgamos que esse estudo se constitui em um fator relevante, já que, em relação à linguagem, o que existe são trabalhos que analisam a linguagem do pantaneiro na perspectiva da Sociolingüística, da Lingüística Textual e da Dialetologia, dentre os quais citamos a tese de doutorado de Nogueira (1989), "A Linguagem do Homem Pantaneiro".

O uso da língua, aliado a outros aspectos do contexto social possibilita ao homem se constituir como sujeito, que estabelece vínculos sociais, com outros sujeitos e com outras culturas, construindo, dessa forma, a sua história. Desse modo, conhecer o povo de uma determinada região pressupõe conhecer suas práticas sociais e, especialmente, sua língua - atividade histórica e social - que torna possível o conhecimento de uma cultura, da qual ela é, também, produto e processo.

No Pantanal sul-mato-grossense, a riqueza lingüística se concretiza pela convivência histórica entre os falantes do português, do espanhol e do guarani, línguas presentes na interação discursiva do dia-a-dia, resultantes do convívio, em regime de fronteira aberta, ou melhor, de fronteira viva, com os países vizinhos Paraguai e Bolívia. Além dos países vizinhos, tem-se, dentro do próprio espaço, a influência de variedades lingüísticas de outras regiões do país, dada a presença de mineiros, gaúchos, nordestinos, paulistas, dentre outros habitantes locais. Hoje, a presença constante de turistas brasileiros e estrangeiros vem contribuindo para a fixação de um novo perfil do Pantanal. 
Embora os indígenas sejam os autênticos habitantes da região, sua influência não foi tão marcante como poderia ter sido, tendo em vista que esses povos indígenas foram aos poucos sendo expulsos das grandes áreas e confinados nas aldeias dos postos indígenas. Mesmo assim, o legado cultural da população indígena local ainda se faz presente em alguns hábitos regionais.

Analisar a linguagem do pantaneiro dentro desse contexto é ter a possibilidade de conhecer esse falante, sua identidade discursiva, as representações que tem de si mesmo e do espaço em que vive e atua. Como afirma Brandão (1998, p. 37):

É porque constitui o sujeito que a linguagem pode representar o mundo: porque falo aproprio-me da linguagem, instauro a minha subjetividade e é enquanto sujeito constituído pela linguagem que posso falar, representar o mundo.

Ampliar pesquisas dessa natureza constitui-se, do nosso ponto de vista, em um avanço que não se refere só aos aspectos lingüísticos reconhecidamente singulares nesse contexto, mas, indo além, refere-se àqueles que, por meio da língua, podem ser evidenciados, já que esta, como observa Geraldi (1996, p. 28.): "[...] enquanto condição de produção da história presente vem marcada pelos seus usos e pelos espaços sociais destes usos".

No que se refere aos aspectos culturais, sabemos que as regiões brasileiras apresentam características bastante diversas e que, em se tratando de Pantanal e pantaneiro, essas características são de uma riqueza singular, haja vista os diversos pantanais, dentro da extensão denominada Pantanal: Paiaguás, Nhecolândia, Abobral, Nabileque, Rio Negro e muitos outros, que resultam em um conjunto formado por diversos ecossistemas, que configura situações de vida diferentes para o homem pantaneiro.

Segundo Nogueira (1990, p. 21), o Pantanal apresenta dois aspectos importantes para a sua caracterização: o isolamento em relação às grandes metrópoles do país e a proximidade com dois países latinos, com os quais, tem convivido intensamente. $O$ resultado desse relacionamento foi a assimilação de 
muitos hábitos e costumes paraguaio-guaranis, hoje integrados ao cotidiano do homem pantaneiro.

Evidentemente, hoje, com a chegada da televisão e da energia elétrica à maioria das fazendas, bem como a existência de pista de pouso em algumas dessas fazendas, o isolamento, que existia nas décadas passadas, já diminuiu bastante, mesmo assim, as chuvas intensas e as enchentes estabelecem esse isolamento, mesmo que temporário.

Outro fator instaurador desse isolamento são as poucas possibilidades de passeios do peão pantaneiro às cidades maiores, em razão, principalmente, das condições de trabalho decorrentes da atividade da pecuária.

No que diz respeito à concepção de linguagem é importante esclarecer que não estamos tratando da linguagem como um sistema fechado de normas, como um código ideal a ser transmitido ao falante, mas de uma outra concepção de linguagem, onde o lugar eleito é o da interlocução, onde a linguagem é vista como uma forma de interação humana: à medida que é produzida pelo uso que dela fazem os sujeitos nas relações sociais, constitui, também esses sujeitos como tais. É por meio dela que os sujeitos passam a compreender o mundo, a importância de sua ação no contexto em que estão inseridos e vão se completando e se construindo pela interlocução.

Concebendo a linguagem dessa perspectiva e reconhecendo a importância que o estudo dessa linguagem tem em relação ao falante, dentro do contexto das interações discursivas, para que se possa evidenciar as imagens que tem de si e do contexto social em que vive, procuramos desenvolver a pesquisa sobre o tema: "Discurso e cotidiano: histórias de vida em depoimentos de pantaneiro".

Dessa perspectiva, a questão que se colocou foi: em que medida é possível evidenciar as imagens do pantaneiro construídas pelo discurso oral do próprio pantaneiro?

Tendo em vista que, como já foi explicitado, pensamos a linguagem como constitutiva do sujeito, defendemos que o discurso do pantaneiro se presentifica nas histórias de vida do próprio pantaneiro, evidenciando, conseqüentemente, a imagem que esse pantaneiro faz dele mesmo, de seu cotidiano, onde constrói e exerce sua visão do mundo. 
Dois objetivos nortearam o desenvolvimento da pesquisa: buscar nas histórias dos pantaneiros a imagem discursivamente construída do homem pantaneiro; conhecer a construção das representações instituídas como sendo a imagem do pantaneiro nas histórias de vida do próprio pantaneiro.

Para tanto, realizamos a pesquisa de campo que compreende os depoimentos de peões pantaneiros que, na sua maioria, já desempenharam quase todos/senão todos os tipos de trabalhos desenvolvidos nas fazendas pantaneiras e são pessoas que nasceram no Pantanal ou para lá foram, há mais de 20 (vinte) anos, movidos pelas necessidades individuais de sobrevivência. Importante ressaltar a razão da opção pelos depoimentos dos peões pantaneiros, já que grande parte dos fazendeiros também é pantaneiro. Alguns aspectos justificam essa opção. $O$ primeiro deles se deve ao fato de que o peão está sempre na fazenda, sendo mais fácil dialogar com ele do que com o patrão que, em tempos de modernidade e novas tecnologias, passa a maior parte do seu tempo nas grandes cidades. A segunda razão é decorrente da primeira, posto que, se o peão é quem realmente vive e convive na região, é ele que tem o que falar sobre a região e sua atuação enquanto sujeito que atua nesse contexto.

Para entrevistar esses pantaneiros, realizamos 05 (cinco) viagens ao Pantanal, em diferentes momentos. O primeiro contato foi no período de 23 a 26/05/2003, em que viajamos para a Pousada Araraúna, que fica na Fazenda Santa Emília, situada no Pantanal do Rio Negro, Mato Grosso do Sul, onde se desenvolve o ecoturismo e se localiza a base de Pesquisa do Pantanal, IPPAN/UNIDERP Ficamos três dias na Pousada e pudemos visitar também as fazendas vizinhas para conversar com os peões pantaneiros ${ }^{1}$. Visitamos a Fazenda Santa Maria, a São Geraldo e a Chão Parado, todas no Pantanal do Rio Negro.

Três meses depois voltamos ao Pantanal ${ }^{2}$, mas não foi possível ir muito longe em razão das chuvas e estivemos em duas fazendas: a Santana e a Taboco,

\footnotetext{
${ }^{1}$ Nessa viagem não conseguimos fazer entrevistas de acordo com o estabelecido, porque visitamos as fazendas sempre em conjunto com um grupo de alunos de Mestrado em Meio Ambiente que faziam uma visita-estudo, com seus orientadores, para entrevistar os pantaneiros, realizar trilhas e realizar experiências nos laboratórios da base. Dessa forma, as pessoas que foram contatadas se viram diante de uma avalanche de perguntas e gravadores e passaram a somente responder ao que Ihes perguntavam. Não foi possível, portanto, conversar separadamente e com um tempo maior com nenhum deles.

${ }^{2}$ Foi uma viagem de oportunidade, junto com uma pesquisadora das escolas pantaneiras e, em razão do trabalho no campo, os peões não se encontravam na sede da fazenda.
} 
próximas ao município de Aquidauana, no chamado Alto Pantanal (onde não há muito problema de enchentes e as estradas são razoáveis), mas como não havíamos agendado o contato com antecedência, não conseguimos conversar com nenhum peão. Passados dois meses, fomos a Aquidauana gravar o depoimento de um pantaneiro aposentado.

Um ano depois, em junho de 2004, estivemos na Fazenda Campo Lourdes, onde conseguimos gravar dois depoimentos. $\mathrm{Na}$ mesma oportunidade, foram entrevistados três peões da Fazenda Santa Emília. Dois meses depois, no final de agosto, fomos ao Taboco gravar uma narrativa com outro peão aposentado e duas com peões que trabalham na Fazenda Paloma, próxima ao Distrito de Taboco Nas três últimas viagens fomos bem sucedidos e conseguimos conversar com tempo e conseqüente tranqüilidade com os peões com quem já havíamos agendado.

A coleta dos dados se realizou por meio de um roteiro que elaboramos com base nos objetivos estabelecidos para o trabalho e com o intuito de estabelecermos um primeiro contato com os pantaneiros. Esse roteiro que chamamos de Roteiro de conversa com os pantaneiros é composto de dois itens, sendo o primeiro deles relacionado à fazenda visitada e o segundo ao pantaneiro. No que diz respeito às fazendas, colocamos aspectos relativos à identificação ${ }^{3}$ (nome, época de fundação, proprietário, rápido histórico da fazenda). Concentramo-nos no item dois relativo ao pantaneiro. Este item ficou subdividido em três blocos que compreendem dados pessoais, trabalho, como se situa e/ou atua nesse espaço, cada um deles com seus questionamentos, conforme roteiro em anexo.

Como bem disse Saussure (2000, p. 16) "é o ponto de vista que cria o objeto". Assim, para fundamentar a análise do tema "Discurso e cotidiano: histórias de vida em depoimentos de pantaneiros" consideramos necessário fazer alguns esclarecimentos teóricos e precisar alguns conceitos de suma importância.

Primeiramente, é necessário dizer que partimos de uma abordagem da linguagem na perspectiva, que se contrapõe à concepção de linguagem defendida por Saussure, que vê a língua como um código abstrato, ideal e homogêneo. Segundo Brandão (1994, p. 9), embora Saussure tenha provocado, com suas idéias, uma revolução científica na lingüística de valor relevante, logo se tornaram evidentes

\footnotetext{
${ }^{3}$ Não foi possível conseguir essas informações, pois os peões desconheciam esses dados e os capatazes que se encontravam nas sedes que visitamos também desconheciam tais dados.
} 
os limites da dicotomia língua/fala, pelas conseqüências da exclusão da fala do campo dos estudos lingüísticos.

Para a autora, dentre os estudiosos que sentiram o engessamento da visão de língua proposta pelo mestre genebrino, está Bakhtin (1986, p.124) que vê a língua como algo concreto, vivo, fruto da manifestação individual de cada falante, valorizando dessa maneira a fala. Defendendo uma concepção de linguagem como forma de interação verbal, o teórico russo atribui lugar privilegiado à enunciação enquanto realidade da linguagem: a matéria lingüística corresponde a uma parte do enunciado; existe outra parte, não-verbal, que corresponde ao contexto da enunciação.

Nessa perspectiva a linguagem é sempre dialógica. É um modo de ação social fundamental no desenvolvimento de todo e qualquer homem e a condição indispensável de apreensão de conceitos que permitem aos sujeitos compreenderem o mundo e nele agir. É ainda lugar de conflito, de encontros, desencontros e confrontos de posições, porque é a linguagem que torna públicas estas posições. (GERALDI, 1991, p. 04).

O sujeito se constitui, portanto, na e pela linguagem; sujeito heterogêneo que deixa de ser visto como único na instância discursiva, para deixar evidente seu caráter contraditório: marcado pela incompletude, deseja "ser inteiro", aproximandose do outro, também incompletude por definição, na busca da totalidade nunca alcançada, constituindo-se nas relações sociais, "entendidas estas como espaço de imposições, confrontos, desejos, paixões, retornos, imaginação e construções" (GERALDI, 1996, p. 20).

Segundo o autor (1996, p. 21), para esse sujeito constitutivamente heterogêneo, parece ser possível atribuir a condição de agente:

[...] no agenciamento dos recursos expressivos que o mobilizam e ele mobiliza, há ações que se realizam com a linguagem (avaliar, persuadir, informar, divertir, convencer, doutrinar, seduzir, etc.), há ações que se realizam sobre a linguagem, criando novos recursos expressivos a partir daqueles já existentes (especialmente através dos processos metafóricos e metonímicos, mas também através de paráfrases, paródias e mesmo utilizando-se da produtividade dos processos de formação de palavras e dos processos de estruturação sintática), e há ações da linguagem que delimitam sistemas antropoculturais de referência através da estrutura categorial, estilo 
de pensamento socialmente condicionado, incluindo ideologias e utopias, que internalizamos nos processos interativos de que participamos e que Löwy (1989) chamará de visões sociais de mundo.

Tomando por base essa concepção de linguagem e de sujeito, o corpus será analisado à luz da Análise do Discurso (AD), estudando os mecanismos interdiscursivos, que remetem à relação texto-contexto. Nesse caso, examinaremos os discursos em questão, levando em conta a interdiscursividade que remete a noções como heterogeneidade discursiva, sujeito, condições de produção entre outros que se inserem no quadro da $A D$ e que fazem parte do processo interlocutivo.

Considerando as nossas pretensões com esta pesquisa, apresentamos, no primeiro capítulo, uma contextualização do Pantanal em seus aspectos geográfico, histórico e social. Procuramos, por meio de mapas e fotos da região, caracterizar esse espaço onde vive e atua o homem pantaneiro. Nesse mesmo capítulo, vamos falar um pouco desse pantaneiro inserido, principalmente, na atividade pastoril, sempre na condição de gerente, capataz ou peão.

Em seguida, traçamos um breve histórico da $A D$ e do sujeito nesse percurso. Partindo do texto de Pêcheux $A$ análise de discurso: três épocas, buscando e acrescentando informações de outros estudiosos que abordaram esse aspecto da AD.

No capítulo três, apresentamos aspectos da $A D$ em sua fase contemporânea, pontuando a questão do discurso, do interdiscurso, do sujeito e as condições de produção nos estudos de analistas do discurso franceses e brasileiros.

Consideramos fundamental esclarecer que, nesses dois capítulos, optamos por um estudo mais detalhado do percurso da $A D$, porque queríamos entender toda a lógica do pensamento dessa tendência.

Tendo em vista que esta pesquisa trabalha com o texto oral, no quarto capítulo retomamos de forma breve o percurso da oralidade, tratamos dos gêneros do discurso e explicitamos o porquê dos gêneros histórias de vida e depoimentos que compõem o título desta tese.

A análise dos depoimentos dos pantaneiros compõe o quinto capítulo deste trabalho. Nesse capítulo, expusemos a nossa forma de olhar os depoimentos 
selecionados para esta pesquisa, levando em conta os aspectos teóricos da Análise do Discurso francesa já explicitados, a partir da ações que o pantaneiro faz com a linguagem, sobre a linguagem e da linguagem em seus discursos.

$\mathrm{Na}$ conclusão, elaboramos as considerações com base na análise feita, levando em conta os questionamentos que nos levaram à pesquisa e os objetivos propostos para chegar à tese que levantamos.

As referências bibliográficas e os anexos compõem a parte final da tese. 


\section{Anúncio}

Este não é um livro sobre o Pantanal. Seria antes um anunciação. Enunciados como que constativos. Manchas.

Nódoas de imagens. Festejos de linguagem. Aqui o organismo do poeta adoece a Natureza. De repente um homem derruba folhas. Sapo nu tem voz de arauto. Algumas ruínas enfrutam. Passam louros crepúsculos por dentro dos caramujos. E há pregos primaveris...

(Atribuir-se natureza vegetal aos pregos para que eles brotem nas primaveras... Isso é fazer natureza.

Transfazer.)

Essas pré-coisas de poesia.

(Manoel de Barros, O Livro de Pré-coisas, 1985, p.15)

Bernardo é quase árvore

Silêncio dele é tão alto que os passarinhos ouvem de longe.

E vêm pousar em seu ombro.

Seu olho renova as tardes.

Guarda num velho baú seus intrumentos de trabalho:

I abridor de amanhecer

I prego que farfalha

I encolhedor de rios - e

I esticador de horizontes.

(Bernardo consegue esticar o horizonte usando três fios

de teias de aranha. A coisa fica bem esticada).

Bernardo desregula a natureza:

Seu olho aumenta o poente.

(Pode um homem enriquecer a natureza com a sua incompletude?)

(Manoel de Barros, O Livro das Ignorãças, 2001, p.97) 


\section{CAPÍTULO I}

\section{O PANTANAL E O PANTANEIRO}

\subsection{O PANTANAL}

Estudar o cotidiano e as representações do homem pantaneiro pressupõe perceber esse homem nas suas relações com o espaço em que vive e atua. Isso implica, no nosso entender, conhecer um pouco da história do próprio espaço investigado: o Pantanal. Segundo dados publicados pela Embrapa Pantanal ${ }^{4}$, o Pantanal é considerado a maior planície neotropical inundável do mundo, com, aproximadamente, $210.000 \mathrm{~km}^{5}$. Ao Brasil pertence uma área de $138.183 \mathrm{~km}^{2}$, que se localiza nos Estados de Mato Grosso (35,5\%) e Mato Grosso do Sul (65,5\%); o restante se estende entre o Paraguai e a Bolívia, onde passa a se chamar Chaco. No Mato Grosso do Sul, a planície do Pantanal se estende entre os paralelos $17^{\circ} \mathrm{e}$

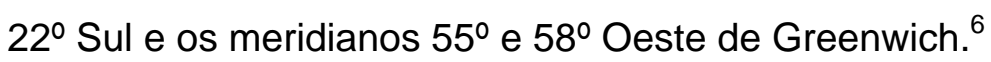

\footnotetext{
${ }^{4}$ A Embrapa Pantanal foi implantada na cidade de Corumbá-Mato Grosso do Sul, em 1975, com o objetivo de desenvolver e adaptar tecnologias para a pecuária de corte do Pantanal, principal atividade econômica da região. Atualmente, seu objetivo é viabilizar soluções tecnológicas para o desenvolvimento sustentável do agronegócio do Pantanal, por meio da geração, adaptação e transferência de conhecimentos e tecnologias. Para isso conta com uma equipe multidisciplinar de pesquisadores e infra-estrutura de pesquisa adequada. MORAES, A. S.et alli Embrapa Pantanal: 25

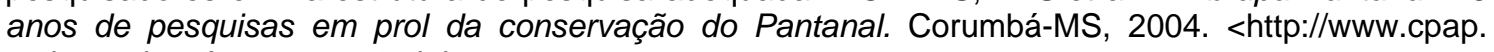
embrapa.br> Acesso em 10 jul. 2004.

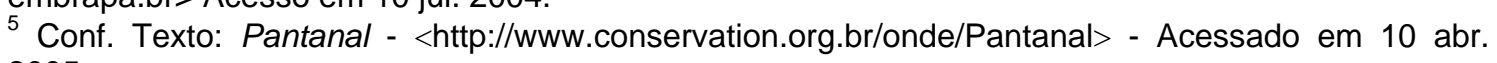
2005.

${ }^{6}$ As estimativas sobre a área e localização do Pantanal diferem de autor para autor. Lécio Gomes de Souza, em História de uma região: Pantanal e Corumbá, apresenta uma superfície total de 200.000 $\mathrm{Km} 2$, que se estende entre os paralelos $16^{\circ}$ e $22^{\circ} \mathrm{S}$ e os meridianos $56^{\circ}$ e $58^{\circ} 30^{\prime} \mathrm{W}$ G. Walnir Pereira, em seu texto sobre o Pantanal, divulgado no site:

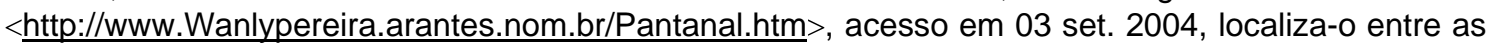
latitudes $\overline{1} 5^{\circ} \bar{S}$ e $23^{\circ} \bar{S}$ e as longitudes $\overline{55^{\circ}}$ e $\overline{6} \overline{0} \bar{W}$, com uma superfície também de $200.000 \mathrm{Km} 2$. Paulo Teixeira, professor da Universidade Federal do Mato Grosso e diretor do Programa Regional de Meio Ambiente do pantanal da Universidade da ONU, afirma em seu artigo ONU: riqueza ecológica do Pantanal está ameaçada (divulgado no site: «́http://nótícias.terra.com.bri - acesso em 10 abr. 2005) que o Pantanal apresenta uma área total de $165.000 \mathrm{Km} 2$, sendo que, dessa área, $85 \%$ fica no Brasil, $10 \%$ na Bolívia e 5\% no Paraguai.
} 


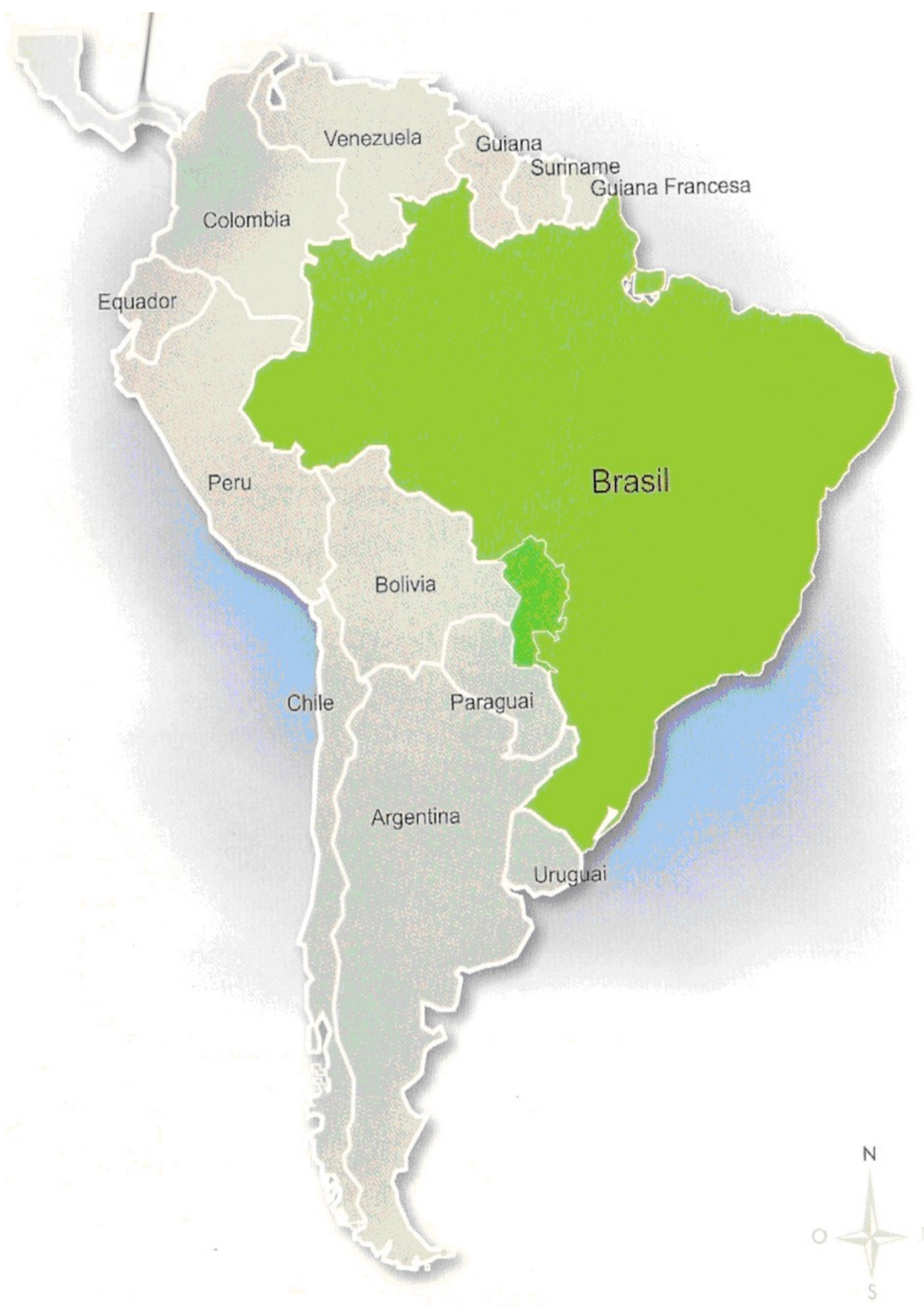

Figura 01 - 0 Pantanal na América do Sul - Brasil, Bolívia e Paraguai 


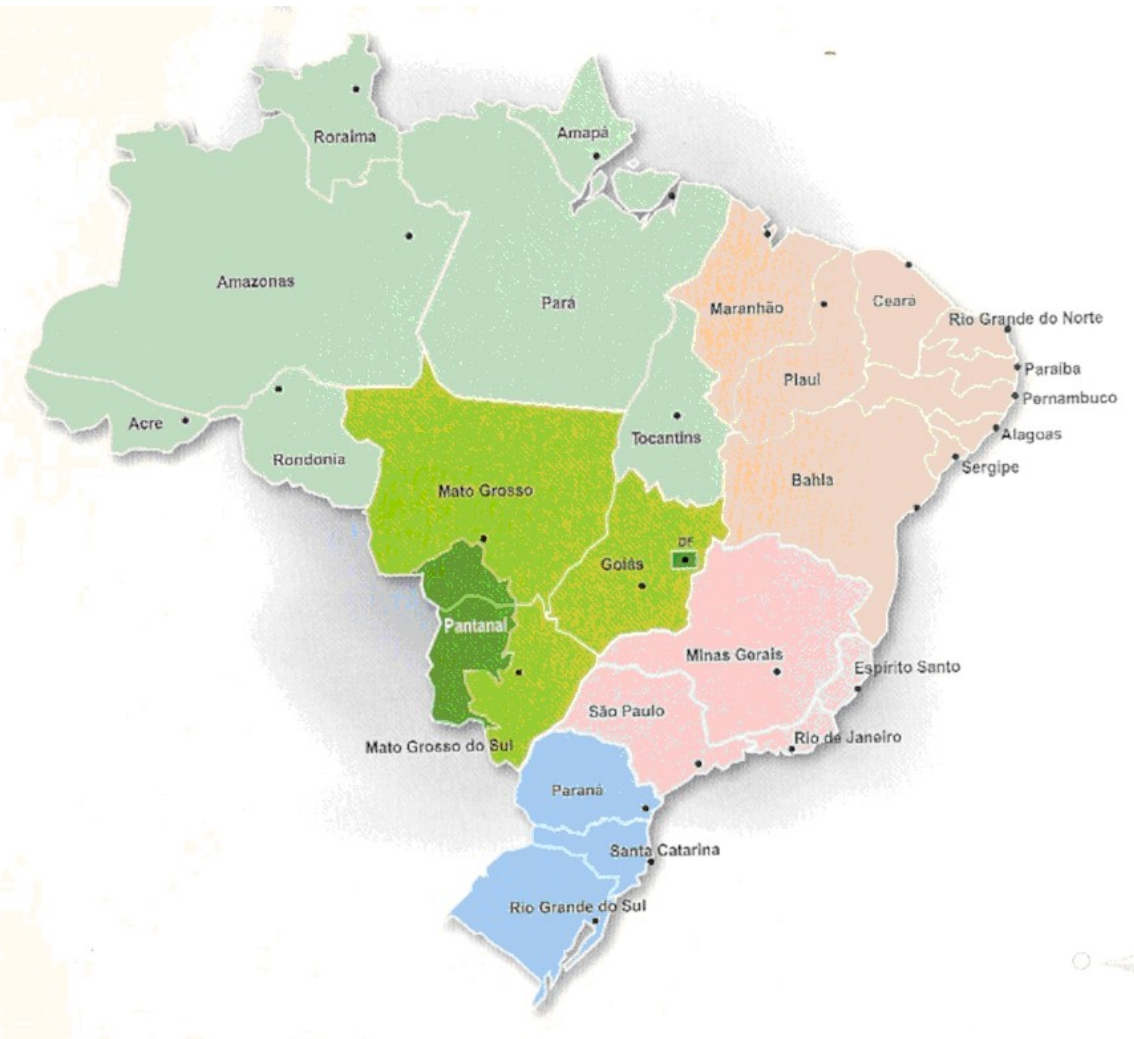

Figura 02 - O Pantanal no Brasil - Mato Grosso do Sul e Mato grosso

Essa planície se constitui em um conjunto de vários ecossistemas, pois é o resultado da influência das regiões fitogeográficas da Amazônia, ao Norte; dos Cerrados, a Leste; do Chaco, a Oeste e, da Mata Atlântica, a Sudeste (MORAES, 2004, p. 06). Segundo os pesquisadores da Embrapa (Empresa Brasileira de Pesquisa Agropecuária), o Pantanal ainda se encontra em processo de formação, isto é, de sedimentação (quaternária), oriunda dos rios da Bacia do Alto Paraguai.

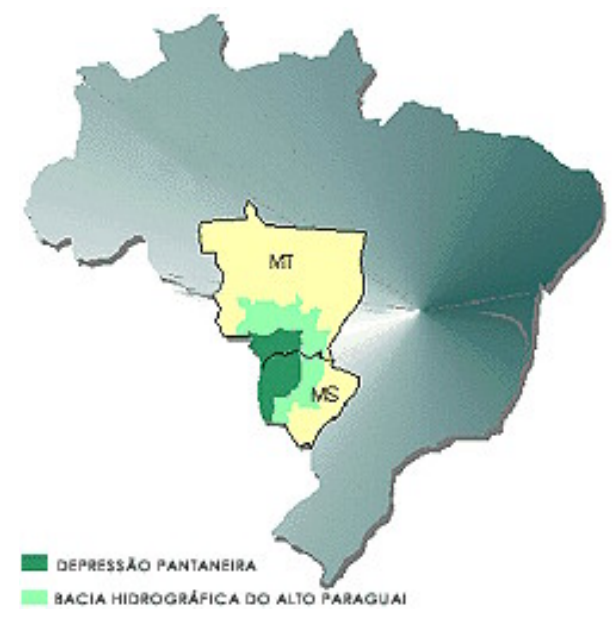

Figura 03 - Bacia doAlto Pantanal 
Todo o Pantanal está inserido nessa Bacia e tem o Paraguai como o mais importante dos rios. Este, amplamente navegável, tem — do lado brasileiro - como afluentes os rios Cuiabá (afluentes: São Lourenço e Piquiri), ao Norte; Taquari (afluente Coxim) e Miranda (afluente Aquidauana) - ao Sul. Esses rios e outros menores como o Nabileque, o Apa e o rio Negro, compõem a trama hidrográfica do complexo pantaneiro (ambientebrasil - on-line, 2005, p. 2), desempenhando um papel de fundamental importância para a região. Segundo Proença (1997, p. 56)

Os rios descem do planalto para influenciar a vida na planície, seja ela animal ou vegetal. São responsáveis por tudo o que acontece de ruim e de bom e, além do mais, estabelecem normas e se fazem respeitar por suas manias e zangas. Quando cheios não são nada comportados: mudam constantemente de curso, abrem bocas, derrubam pontes, devastam plantações ribeirinhas, entopem vazantes e baías, carregam entulhos, inundam sedes de fazendas, cobrem campos de aviação e matam animais.

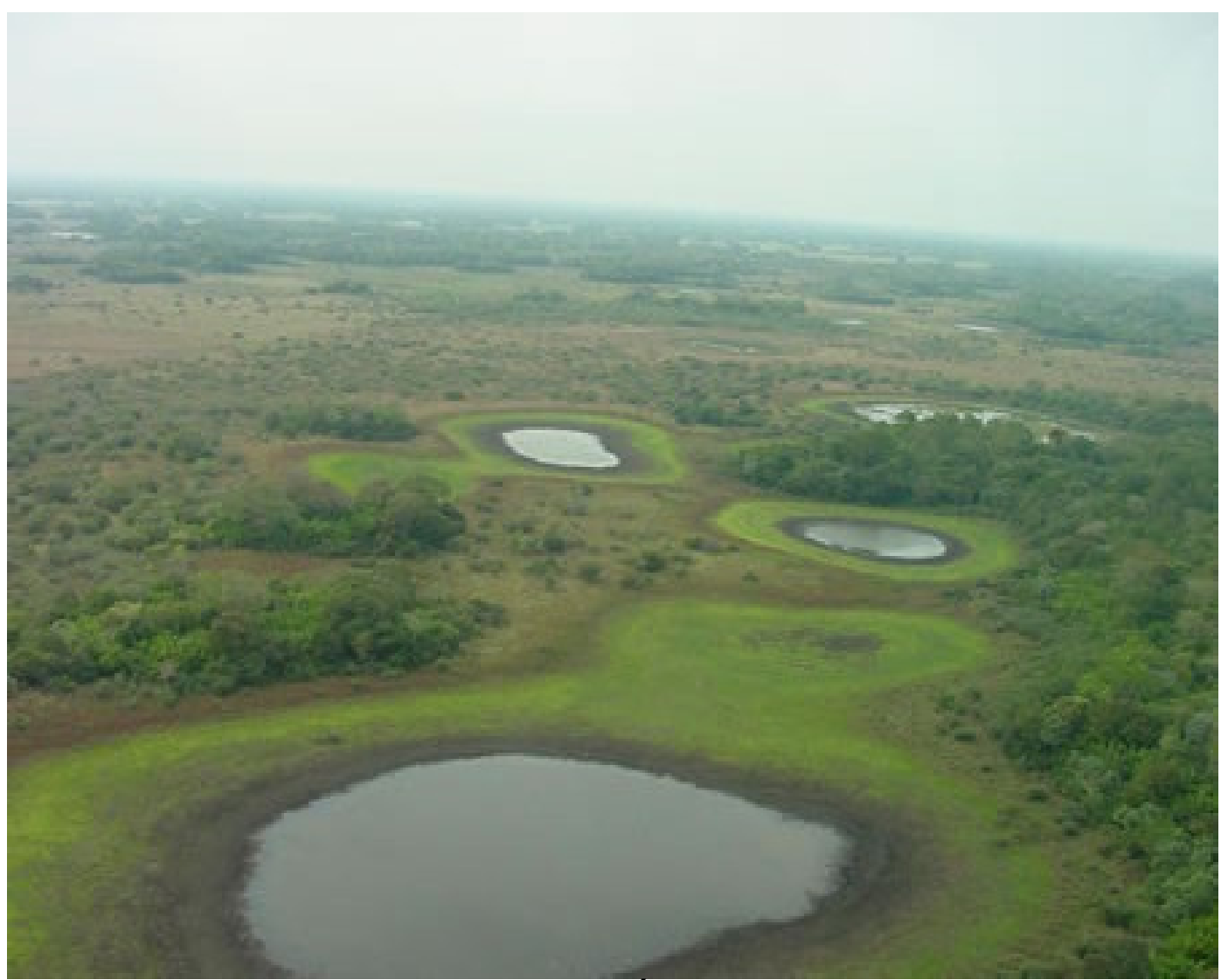

Figura 04 - Áreas alagadas do Pantanal 
Além desses rios, a planície pantaneira apresenta áreas alagáveis como as baías, as vazantes, os corixos e as salinas. As baías são lagoas de água doce, de formas circulares e/ou irregulares — rasas ou profundas — com vegetação intensa e variedade de peixes. Segundo Souza (1973, p. 29), as mais importantes são alimentadas pelo rio Paraguai:

A oeste estende-se o cordão das grandes lagoas, regionalmente conhecidas por "baías" e que se comunicam com o rio através de sangradouros, sendo por ele alimentadas. Destacam-se as de Uberaba, Gaíva, Mandioré e Cáceres, escalonadas de norte a sul, umas vastas e profundas [...]

Há, ainda no Pantanal, uma grande quantidade de pequenas e médias baías, drenando-se para os rios. As vazantes são baías de água corrente, normalmente o leito de escoamento das enchentes e fontes de gramíneas na seca (wanlypereira.arantes - on-line, 2004, p. 2). Os corixos são pequenos cursos d'água com leito definido, que no período das secas diminuem, mas não secam. Normalmente estão ligados a algum rio. As salinas são lagoas de água extremamente alcalina, com sabor, cheiro e cor acentuados, apresentando estas características em razão do intenso desenvolvimento de algas microscopias (MORAES, 2004, p. 2). Por ser uma água rica em carboidratos de sódio e de potássio é muito procurada pelo gado e pelos outros animais da região.

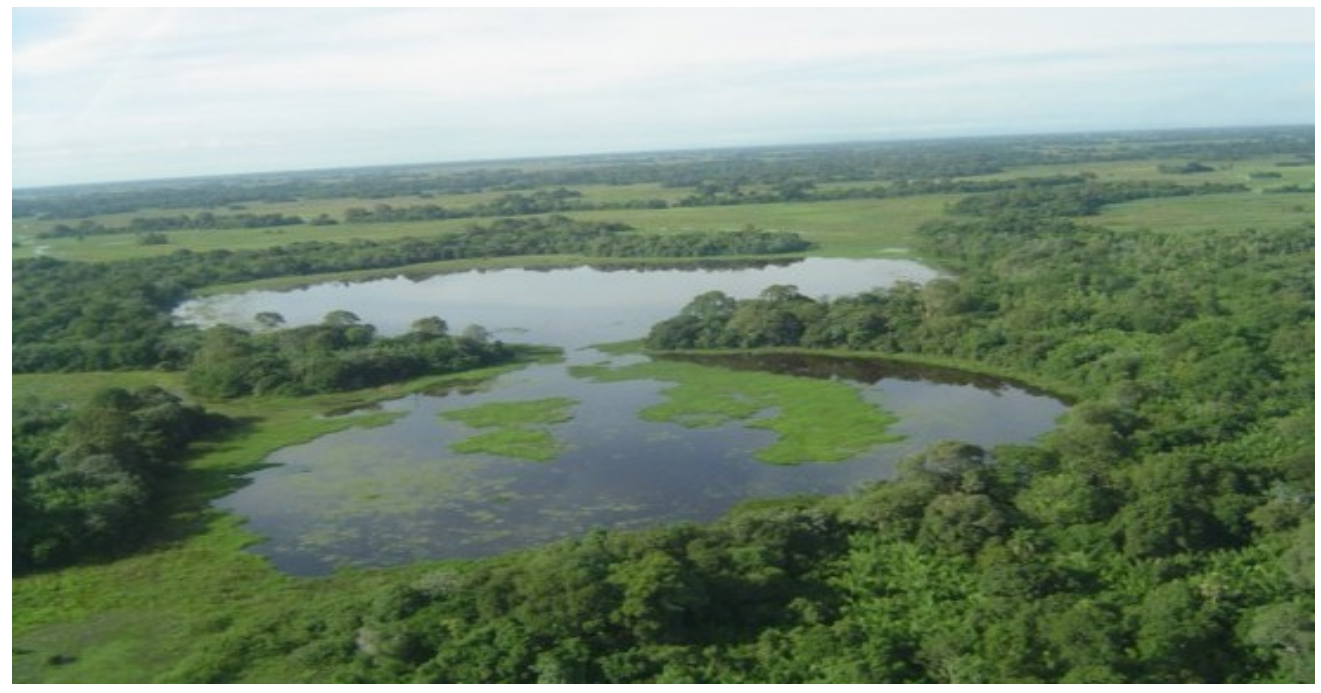

Figura 05 - Baías 
Com um clima predominantemente tropical e úmido, a região pantaneira apresenta uma temperatura média anual que varia entre mínima de $15^{\circ} \mathrm{C}$ e máxima de $34^{\circ} \mathrm{C}$. No verão, a temperatura é alta, atingindo as máximas absolutas de $40^{\circ}$ a $42^{\circ} \mathrm{C}$, ou mais. Duas únicas estações do ano - a das águas e a da seca - se fazem presentes na região. Segundo Nogueira (1989, p. 25), essas estações, em uma alternância mais ou menos regular, de estio no inverno e de chuvas no verão, regulam, em situação normal, a época da seca, no período de abril a setembro, e a das cheias, que vai de outubro a março. Em alguns anos, pode acontecer que 0 período das águas só comece em janeiro.

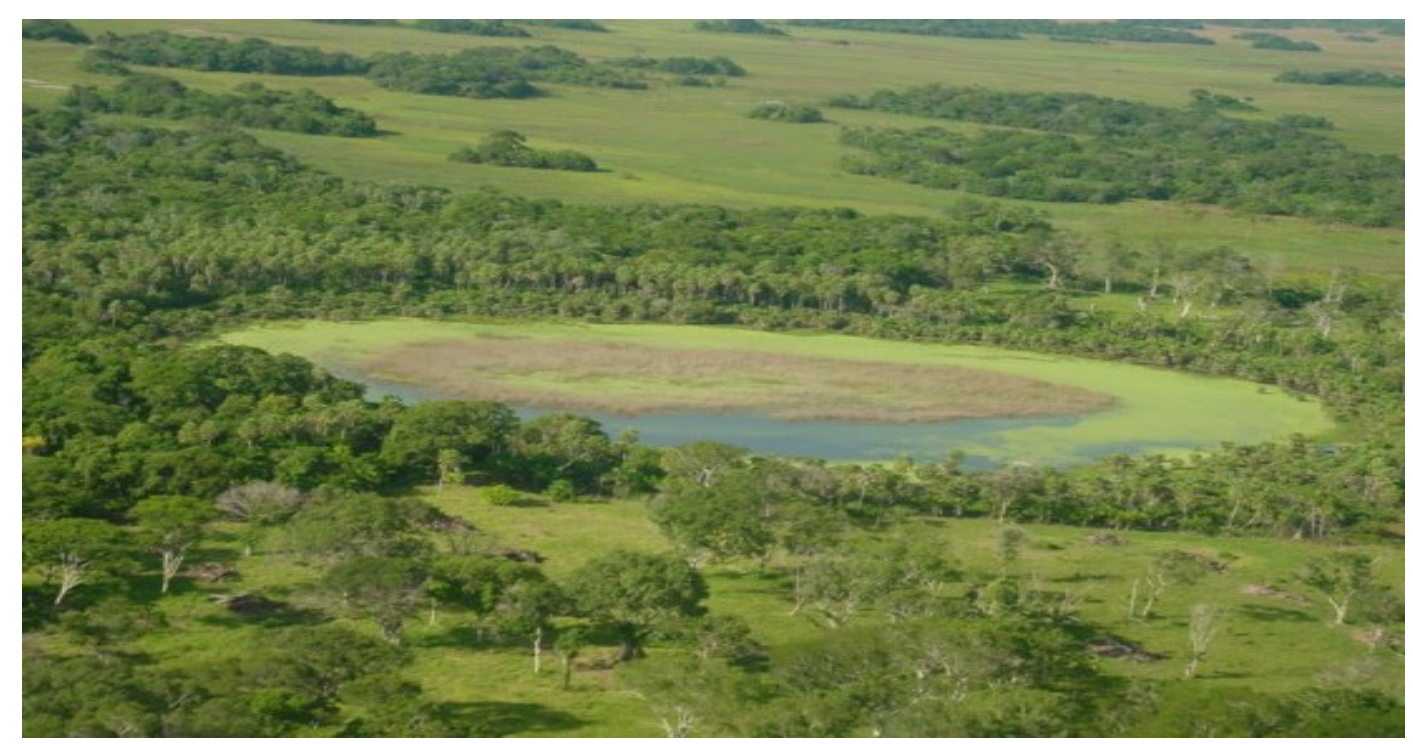

Figura 06 - Salinas

No tempo da seca, as águas diminuem, limitando-se ao leito dos rios, às lagoas próximas a esses rios e aos banhados existentes nas áreas mais baixas da planície. Os campos, nessa época, ficam cobertos predominantemente por gramíneas e vegetação do cerrado. No período das cheias, as depressões são inundadas, formando extensas baías que, quando alcalinas, apresentam-se em cores variadas, de acordo com as algas que ali se desenvolvem, criando matizes de verde, amarelo, azul, vermelho ou preto. 


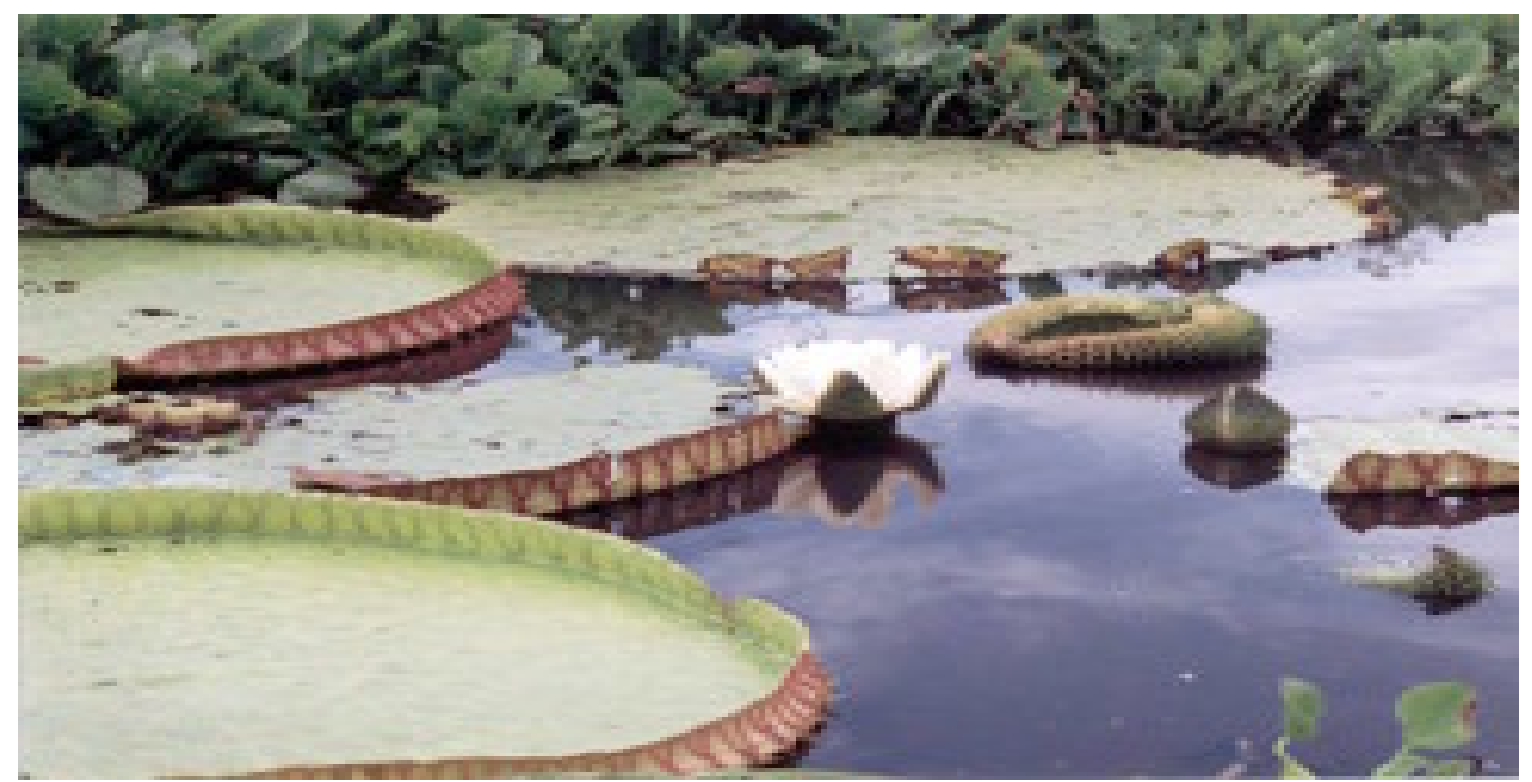

Figura 07 - Vitória-régia nos corixos

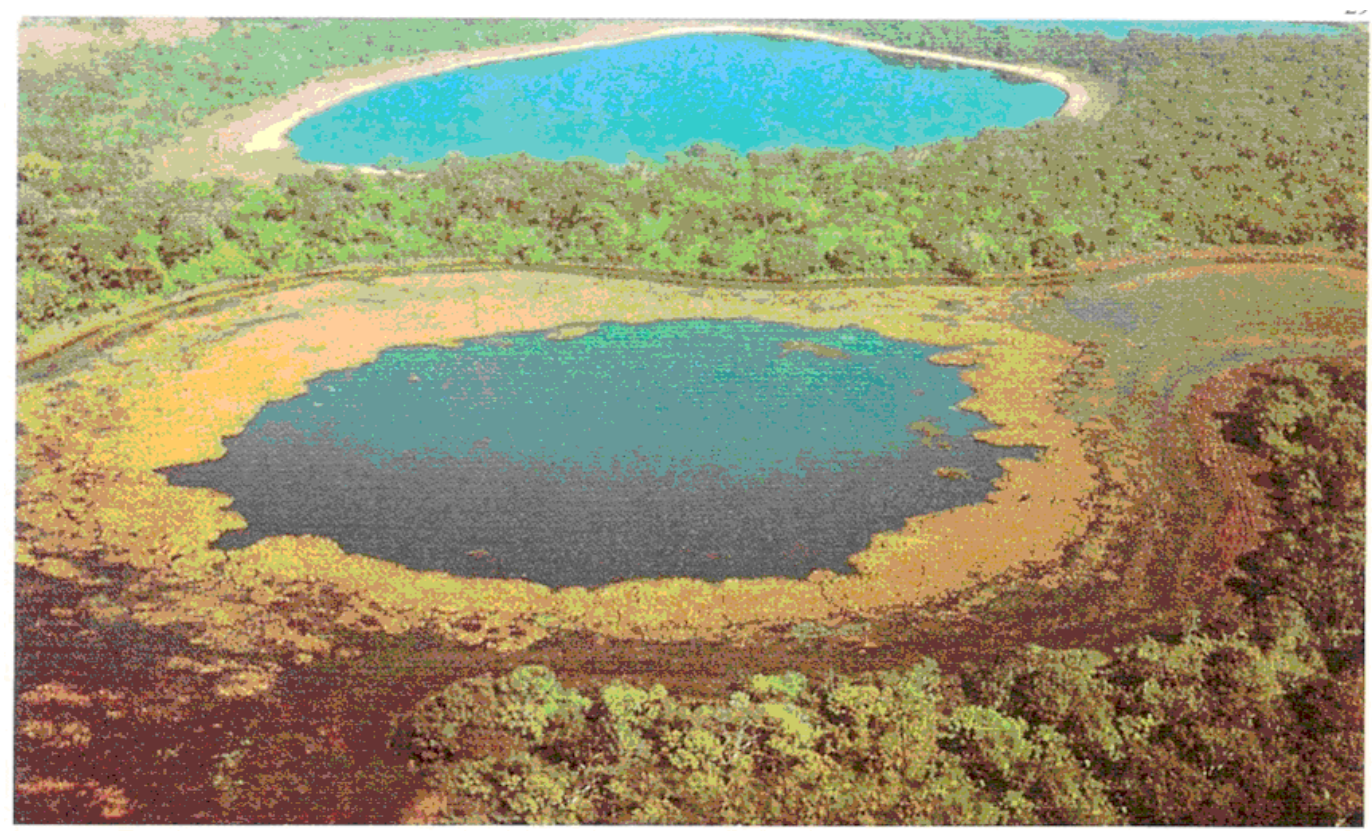

Lagoas salgadas em Mato Grosso do Sul

Figura 08 - Salinas

O Pantanal que, como já referido, se constitui de características fitogeográficas do Chaco, da Floresta Amazônica e dos Cerrados, apresenta uma enorme diversidade em espécies animais e vegetais. Até o ano de 2003, foram estimadas aproximadamente "3.500 espécies de plantas, 432 de aves, 124 de mamíferos, 177 de répteis e 41 de anfíbios" (conservation - on-line, 2005, p. 1).Essa rica biodiversidade e a singularidade de seu ecossistema colocam o Pantanal como 
"uma das 37 últimas Grandes Regiões Naturais da Terra" (conservation - on-line, 2005 , p. 02).Sua vegetação se constitui em uma das mais variadas com trechos de cerrados, matas, campos limpos, vegetações minúsculas aquáticas até palmeiras e árvores de grande porte, formando as cordilheiras ${ }^{7}$ e os capões.

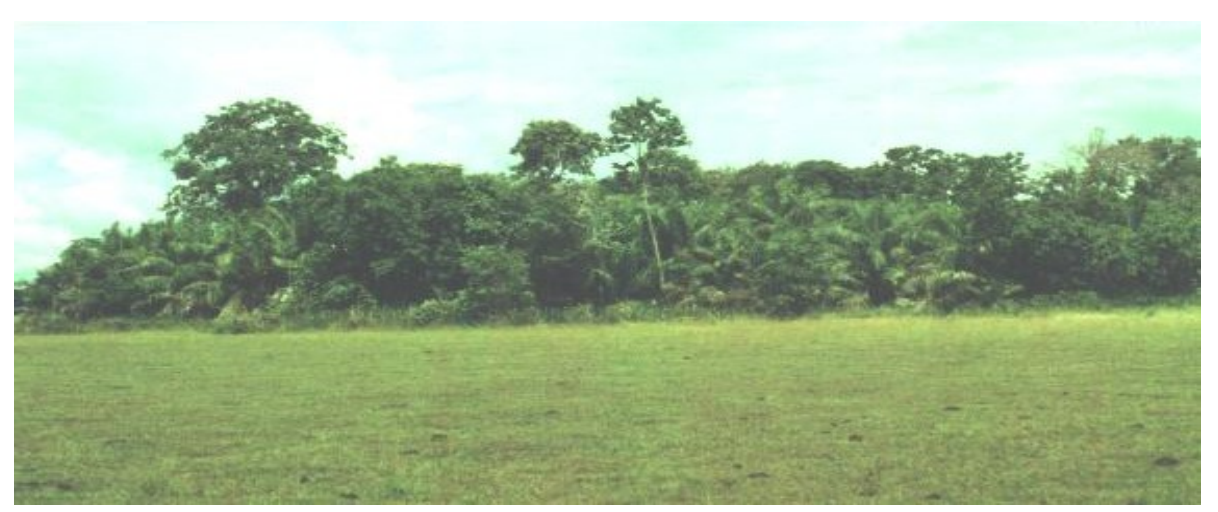

Figura $09-$ Cordilheiras

A vegetação pantaneira é mais densa nas áreas não inundáveis, geralmente diminuindo essa densidade nas áreas que inundam temporariamente. Isso se deve ao fato de que, durante a inundação, grande parte dos arbustos morre, reaparecendo novos indivíduos durante o escoamento das águas. Já as várias espécies flutuantes são próprias das áreas que permanecem inundadas. Há também as áreas onde predomina uma espécie única de vegetais como os buritizais ${ }^{8}$, paratudais ${ }^{9}$, carandazais ${ }^{10}$, etc.

Em meio a essa diversidade da vegetação, encontra-se uma fauna bastante rica, da qual faz parte o maior felino brasileiro: a onça-pintada ${ }^{11}$.

\footnotetext{
${ }^{7} \mathrm{O}$ ambiente das cordilheiras lembra ora o cerrado denso, com madeiras nobres, como a Arueira e o Ipê ou Piúva, ora a caatinga com tunas, espinhos e muita areia. Já nas vazantes, temos o campo limpo, paraíso para os cavaleiros e suas vaquejadas os quais compõem a paisagem econômica e cultural do Pantanal (ARANTES, 2004, p. 03).

${ }^{8} \mathrm{O}$ buritizeiro (Mauritia flexuosa) é uma palmeira comum. Ele ocorre tipicamente em pequenos bosques mono-específicos chamados buritizais, localizados em áreas pantanosas de lençol freático alto e de freqüente alagamento raso.

${ }^{9}$ Formados por um tipo de ipê chamado de paratudo. Site; ihttp://www.bōeco.org/site/biomas.asp?idBioma=10̄ - acessado em abril de 2007.

To Formado pela palmeira carandá.

11 Atingindo até 130 quilos, vive nas matas e compartilha o território com outras espécies de mamíferos, entre os quais se destacam antas, jaguatiricas, gatos-do-mato, canídios - como o cachorro-vinagre e o tímido notívago lobo-guará (ecossistemas, on-line, 2005, p. 02).
} 


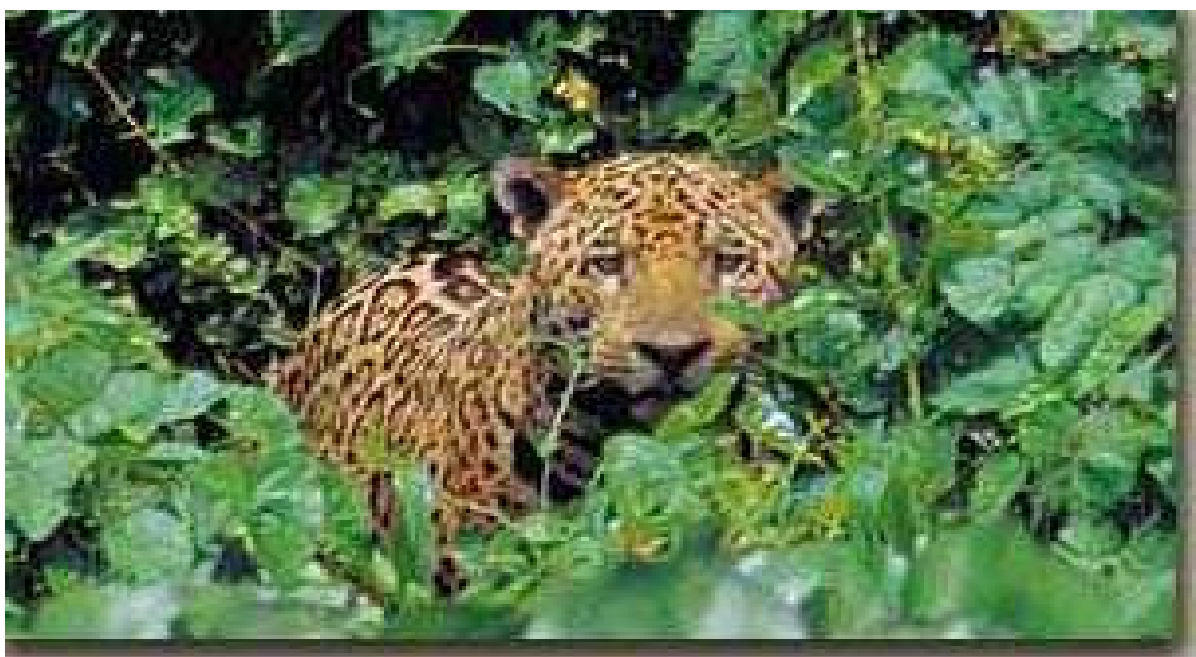

Figura 10 - Onça Pintada

Outros animais de rara beleza constituem a fauna pantaneira. Grande variedade de peixes de escamas e de couro - de pequeno a grande porte - como também moluscos e crustáceos, vivem em seus rios e baías. Junto às águas e seu entorno, vive o jacaré pantaneiro e outros bichos como cágados, lagartos e algumas espécies de cobra - entre elas as enormes sucuris. É da região também, o maior roedor do mundo: a capivara que, em seu habitat, vive em bandos.

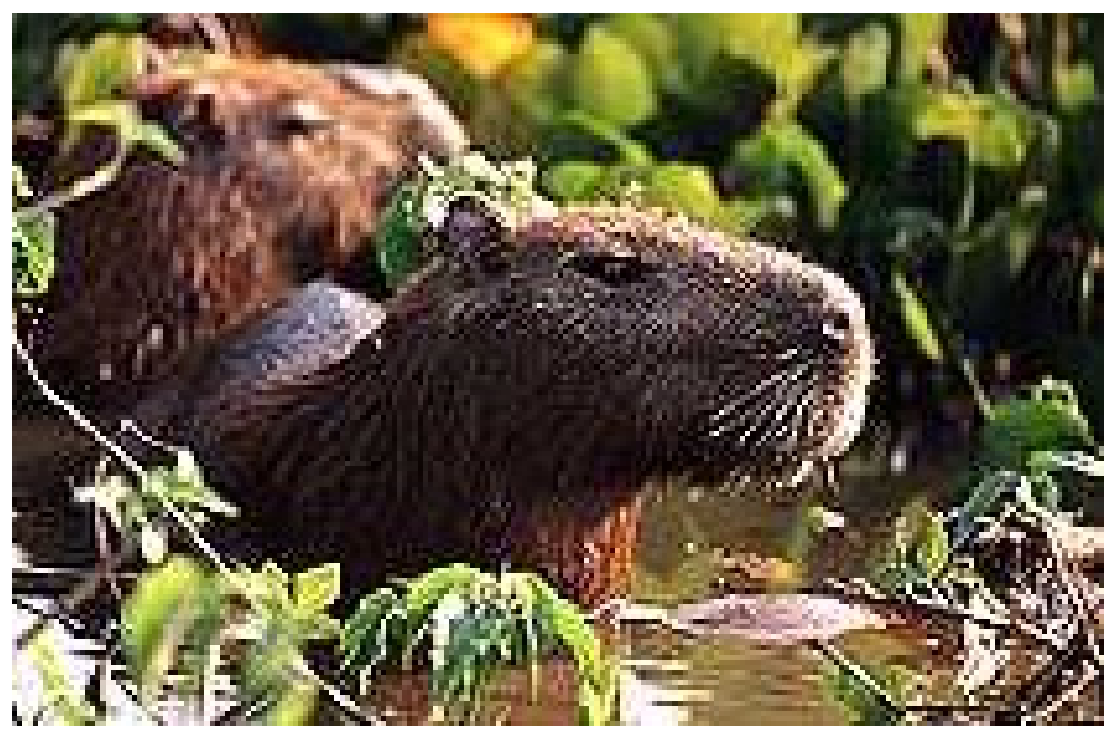

Figura 11 - Capivaras 


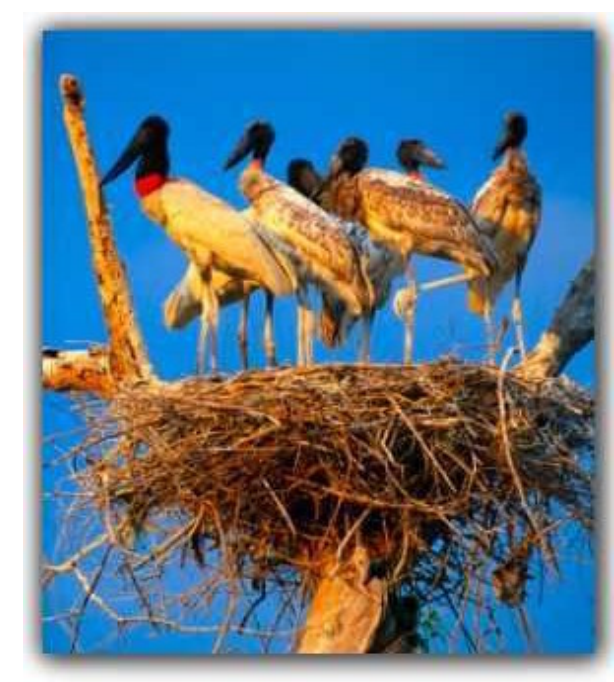

Figura 12 - Tuiuiús

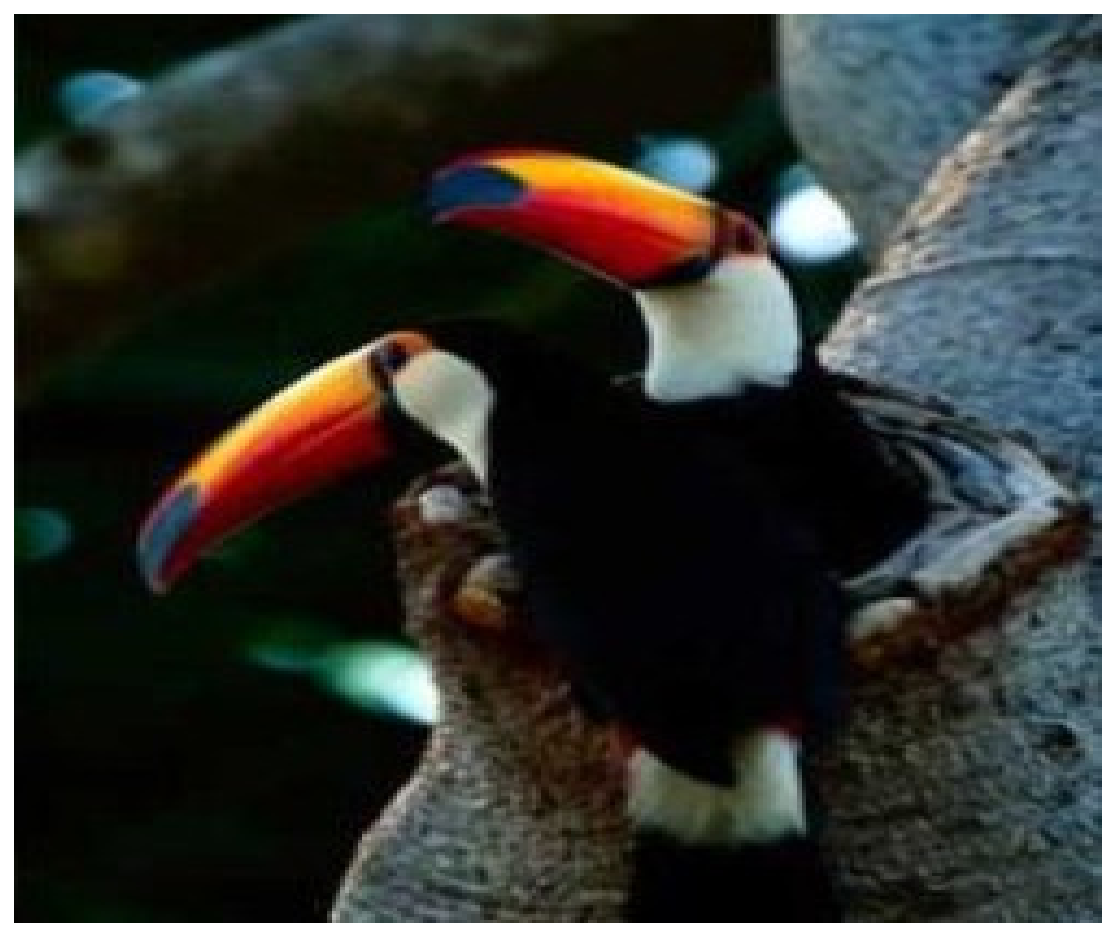

Figura 13 - Tucanos

As aves que fazem parte do ecossistema pantaneiro, apresentam uma grande variedade de espécies, indo desde as pernaltas como as garças, o tuiuiú (ou 
Jaburu), o colheireiro e as cabeças-secas que - em grandes bandos, andam calmamente sobre as águas, procurando alimento - até os diversos tipos de pássaros, entre eles o anu-branco (considerado um grande controlador biológico, pois alimenta-se de vários tipos de insetos), bem-te-vis, pica-paus e o arapaçu-debico-torto, entre outros.

Dessa maneira, o período das águas e o período da seca, integrados às singularidades do ecossistema pantaneiro, tornam o Pantanal significativamente diferente de outras regiões e isso se reflete no cotidiano do homem pantaneiro, bem como nos hábitos dos animais e no desenvolvimento dos vegetais. Conforme observa Proença (1997, p. 14)

As atividades humanas se diferenciam das congêneres em outras paragens. A adaptação dos processos de trabalho, de meios de sobrevivência, de hábitos de vida às condições climáticas regionais, distinguem perfeitamente as fazendas pantaneiras de criação de quaisquer outras do planalto.

Schneider (2002, p. 44) acrescenta:

A biodiversidade do Pantanal favorece ora as espécies animais e vegetais relacionadas à seca e ora as relacionadas ao período de chuvas. Além disso, uma favorece a outra, pois as espécies animais mortas pela inundação, por meio do processo de decomposição, fornecem os nutrientes e sais que contribuirão para 0 desenvolvimento de espécies animais aquáticas.

E Proença (1997, p. 14) completa:

E dessas renovações vêm um novo ciclo de vida que se expande nas campinas verdes, revoadas de cabeças-secas, garças, tuiuiús, colheireiros, baguaris, $\left({ }^{*}\right)$, se reencontrando nas vazantes umedecidas à procura dos peixes lerdos que não conseguiram voltar para os rio se, caso não deglutidos pelas aves, irão se misturar aos microorganismos vegetais, transformando-se em matéria orgânica da melhor qualidade.

Essa biodiversidade oportuniza a caracterização de duas áreas diferentes: o Pantanal alto que compreende as regiões mais altas, onde as enchentes são menos freqüentes e o Pantanal baixo formado pelas partes baixas e depressões, sujeito a inundações periódicas. Essas regiões se caracterizam, principalmente, pela 
vegetação, pelo tipo de solo e pelas duas estações que predominam no Pantanal: a da seca e a das águas.

No período da seca os campos geralmente são cobertos por gramíneas e vegetação de cerrado. No período das águas, a vegetação varia de acordo com o tipo de solo e de inundação, predominando espécies de cerrados nas terras arenosas do Pantanal Alto e de gramíneas nas terras argilosas do Pantanal Baixo.

Essas duas áreas compreendem, na realidade, vários pantanais que, de acordo com Nogueira (1989, p. 26), são resultantes da intrincada rede hidrográfica, formada pelo rio Paraguai e seus tributários, que condicionam a vegetação, a fauna, as condições do solo e a vida do homem que a habita.

Essas sub-regiões — de paisagens diferenciadas, tanto no que se refere aos aspectos naturais, quanto à forma de ocupação humana - apresentam diferentes classificações defendidas por historiadores e estudiosos do Pantanal, bem como por projetos governamentais. Para isso, esses pesquisadores utilizam como critério os hábitos e costumes, bem com os tipos de vegetação de cada local e/ou os rios que o atravessam. No seu conjunto, essas singularidades compõem os aspectos socioculturais e econômicos do Pantanal, como um todo.

Das várias classificações apresentadas, temos a classificação do IBGE, dos pesquisadores locais ${ }^{12}$, do projeto RADAMBRASIL ${ }^{13}$ e a classificação segundo o Macrozoneamento Geoambiental do Mato Grosso do Sul.

Existem diferentes formas de dividir o Pantanal. Alguns autores o dividem em 6, 8, 10, 11 ou mais. De acordo com o Macrozoneamento Geoambiental do Mato Grosso do Sul, podemos identificar os seguintes pantanais no Estado: Pantanal de Uberaba-Mandioré, Pantanal da Nhecolândia, Pantanal de Paiaguás, Pantanal do Negro-Aquidauana, Pantanal do Negro-Miranda, Pantanal do Baixo TaquariParaguai, Pantanal do Aquidauana-Miranda, Pantanal do Castelo-Mangabal, Pantanal do Corixão-Piúva-Viveirinho, Pantanal da Baía Vermelha-Tuiuiú, Pantanal

12 Pesquisadores das Universidades públicas e particulares do Estado e a Embrapa Pantanal desenvolvem projetos no/sobre o Pantanal sul-mato-grossense.

${ }^{13}$ O Projeto Radambrasil, que operou entre 1970 e 1985 , foi dedicado à cobertura de diversas regiões do território brasileiro (em especial a Amazônia) por imagens aéreas de radar, captadas por avião. $\mathrm{O}$ uso do radar permitiu colher imagens da superfície, sob a densa cobertura de nuvens e florestas. Com base na interpretação dessas imagens, foi realizado um amplo estudo integrado do meio físico e biótico das regiões abrangidas pelo projeto, que inclui textos analíticos e mapas temáticos sobre geologia, geomorfologia, pedologia, vegetação, uso potencial da terra e capacidade de uso dos recursos naturais renováveis, que até hoje é utilizado como referência nas propostas de zoneamento ecológico da Amazônia brasileira. 
do Apa-Amonguijá-Aquidabã, Pantanal do Rio Verde e Pantanal do JacadigoNabileque.

Os pantaneiros, por sua vez, estabelecem a sua classificação. Para eles existem os pantanais do Rio Negro, do Aquidauana, do Miranda, do Abobral, do Apa, do Tereré e do Jacadigo, levando-se em conta, em quase todos, o papel exercido pelos rios. Ou, ainda, os pantanais do Minhocal, da Areia, do Barro, para os quais são considerados os tipos de solo (NOGUEIRA, 1989, p. 26). Entretanto, a divisão mais conhecida e/ou citada é a seguinte: Pantanal do Aquidauana, do Paraguai, de Nhecolândia, do Abobral, do Miranda, do Nabileque e do Paiaguás.

Conforme observa Nogueira (1989, p. 27) [...] os pantaneiros, embora conscientes da coexistência de vários pantanais, dentro do Pantanal maior, referemse à região denominando-a simplesmente de Pantanal ${ }^{14}$.

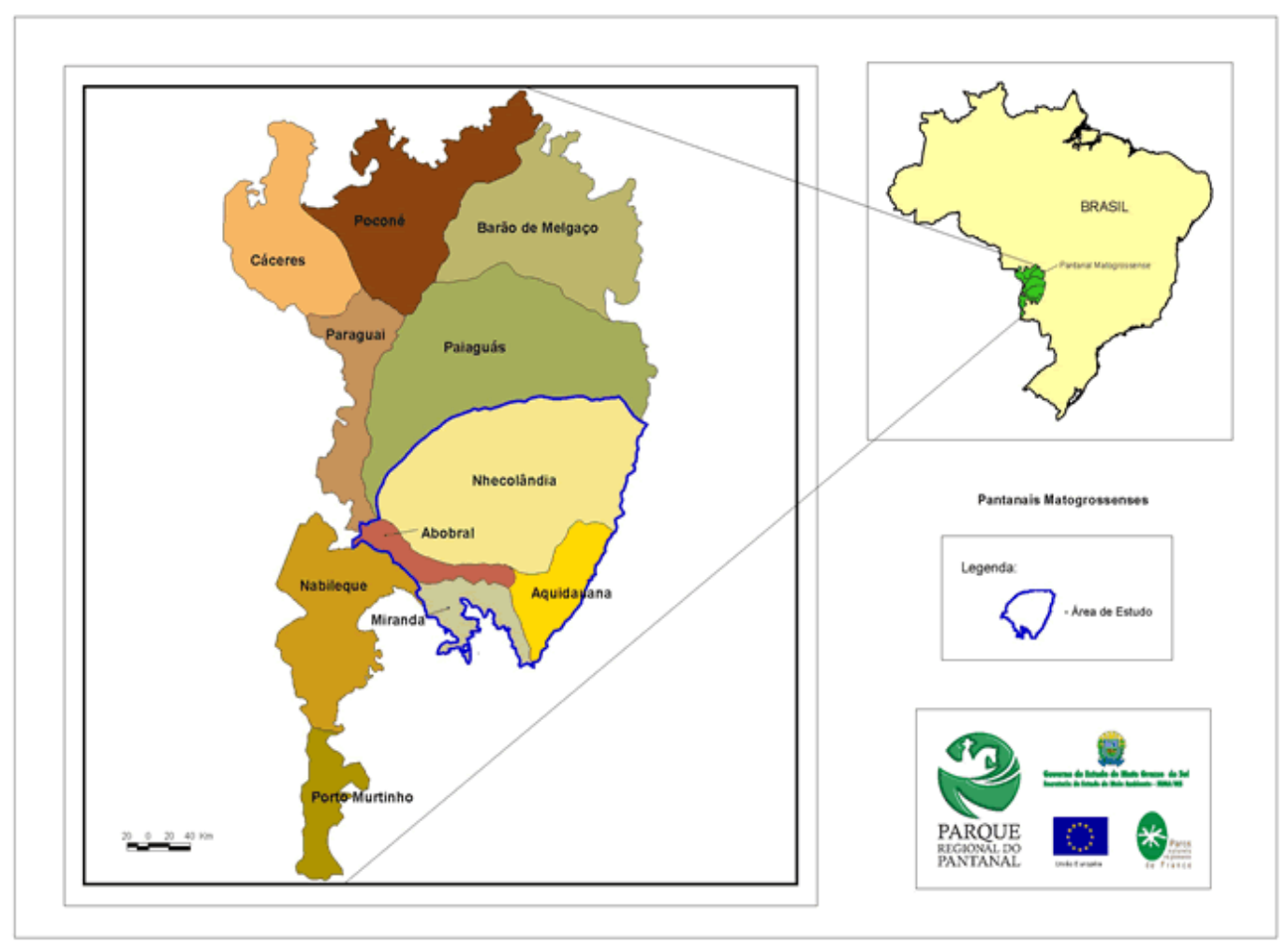

Figura 14 - Os Pantanais

\footnotetext{
${ }^{14}$ Neste trabalho, optamos pelo uso da palavra Pantanal de conformidade com os pantaneiros.
} 
No aspecto econômico, tem relevância a formação dos grandes latifúndios e, dentro deles, a criação de gado; o desbravador-pioneiro; o peão pantaneiro, bem como o cavalo pantaneiro, o qual se constituiu no principal meio de locomoção, diante de tantas águas. Proença (1992, p. 55) afirma que:

[...] terminada a fase de consolidação de fronteiras, construídos os povoados, fundados os fortes, feitas as manobras para apagar a chama guerreira dos índios paiaguás, e ainda devido à decadência das lavras auríferas que facilmente se exauriam, era necessário incrementar uma outra atividade econômica na imensa planície pantaneira. Para isso, quatro elementos foram fundamentais: 0 desbravador-pioneiro, o vaqueiro, o cavalo e o boi.

Segundo o autor (1992, p. 55), o desbravador ${ }^{15}$ era o descendente de índio e bandeirante mameluco paulista que, com o declínio das minas de ouro, buscou outra atividade em que pudesse prosperar. A miscigenação fez desse homem um forte. Dos nativos herdou a humildade, a desconfiança e a paciência e do mameluco o ardor, a coragem e a ambição. Essas características foram fundamentais para que pudesse enfrentar os obstáculos que a região apresentava.

$O$ vaqueiro se constituiu da miscigenação dos índios - principalmente das etnias guató, guaná, xamacoco e guaicuru - com os donos da terra. $O$ negro escravo que veio para trabalhar nas minas de ouro e posteriormente com a cana de açúcar também contribuiu na formação étnica do vaqueiro do Pantanal, bem como o paraguaio de quem o vaqueiro assimilou muitos costumes, dentre eles, o do tereré.

Esses homens tiveram sempre a seu lado a companhia das mulheres na luta pelo desbravamento e colonização do Pantanal. Como afirma Proença (1992, p. 57)

[...] devemos também reservar o lugar da mulher: da mulher companheira do desbravador e do vaqueiro; da mulher negra, escrava, enchendo as nossas cozinhas de estórias e quitutes, e fabricando mulatos nas horas vagas; da mulher índia (a cunhã), carregando o filho nas costas enquanto trabalhava na lavoura ou servia de besta de carga ao marido errante pela picadas sem fim do Pantanal, ou ainda participava das danças festivas em entretinha os visitantes nas noites de saraus; da mulher portuguesa, que se integrou aos nossos costumes, ensinando-nos os dela, em sua maioria administrando o patrimônio com fibra de macho.

\footnotetext{
${ }^{15}$ Esses desbravadores-pioneiros se tornaram donos das sesmarias (doações de extensões de terras chamadas devolutas, em troca do cultivo no prazo de três anos), mas raramente permaneceram só com o núcleo doado e, diante de tanta terra, requeriam mais principalmente lugares altos para criar o gado longe das enchentes. Dessa maneira, deu-se a origem do latifúndio na região.
} 
O cavalo e o boi vieram com os espanhóis. O primeiro fez parte das expedições aventureiras que passaram pela região e foi extraviando-se pela planície e, adaptando-se às condições locais, tornou-se um animal quase anfíbio, resistente que auxiliou no povoamento do Pantanal. Já o boi chegou à região por meio de Dona Ana Pimentel que trouxe o primeiro plantel de gado. Esse pequeno rebanho aumentou, multiplicou-se, expalhando-se Pantanal afora (PROENÇA, 1992, p.55$56)$.

Dentre os animais, o autor destaca ainda o cão como o amigo de todas as horas, das caçadas ou auxiliando o homem a conduzir as vaquejadas. Essas pessoas e esses animais desempenharam um papel importante na formação material, cultural e econômica da região.

Esse bovino pantaneiro, introduzido no Brasil no início da colonização, desempenhou/desempenha um papel de destaque na economia das áreas inundáveis do Pantanal Sul-mato-grossense, pois, conforme observa Mazza et. all (1989, p. 2):

O longo processo de seleção natural por que passaram esses
bovinos lhes permitiu adaptar-se ao ambiente peculiar do Pantanal,
suportando condições climáticas e hidrológicas extremas,
caracterizadas por elevadas temperaturas no verão (com máximas
absolutas ultrapassando $40^{\circ} \mathrm{C}$ ) e alternância entre períodos secos e
enchentes consideráveis. Algumas das características da adaptação
adquiridas pelo gado Pantaneiro relacionam-se à grande rusticidade,
destacando-se a resistência à escassez de alimentos e a certas
doenças.

A pecuária extensiva foi, portanto, a principal responsável pela ocupação da região, tornando-se a atividade primeira das imensas fazendas. Nos primeiros tempos, o destaque era para o comércio de charque e couro, que deu origem aos grandes saladeiros ${ }^{16}$. Depois, esse comércio foi substituído pelo de bovinos vivos, surgindo as grandes comitivas que conduziam o gado para as pastagens, principalmente, da região Nordeste Paulista, do Triângulo Mineiro e mais tarde para o Oeste Paranaense.

\footnotetext{
${ }^{16}$ Os saladeiros eram os locais preparados para produzir o charque (carne de sol) também chamados de charqueadas.
} 
Atualmente, o Pantanal Sul-mato-grossense tem como principal atividade econômica a pecuária de corte, principalmente nas fases de cria e recria; muito embora ainda exista o comércio do gado em pé.

Segundo pesquisadores da Embrapa-Pantanal ${ }^{17}$, as pastagens nativas representam um bem de valor econômico, na medida em que sustentam a pecuária de corte como atividade primeira da região. O segundo bem de valor econômico é o peixe, que sustenta uma pesca profissional e esportiva altamente desenvolvidas. Outra atividade que está surgindo na região é a apicultura, baseada nas plantas apícolas nativas, com possibilidade de produção de mel de alta qualidade e passível de exportação na forma de mel orgânico.

Os animais da fauna nativa, como jacarés e capivaras - dada a potencialidade do seu uso como produtores de carne, couro e outros derivados são considerados pelos pesquisadores como bens de valor econômico direto. Pelo seu uso no ecoturismo - empreendimento considerado promissor para a economia da região - esses animais, juntamente com a fauna e a flora altamente diversificadas, podem também ser considerados bens de valor econômico indireto.

A agricultura desenvolvida no Pantanal é praticada mais para a subsistência, não assumindo, portanto, maior significado econômico. No que diz respeito ao extrativismo vegetal [...] a madeira substituiu a erva-mate e o quebracho ${ }^{18}$, dois produtos importantes, no passado, que acabaram perdendo a concorrência, tanto no mercado estadual, como fora dele (NOGUEIRA, 1989, p. 25).

Essa região que hoje conhecemos como Pantanal não teve sempre essa denominação. Bem antes de ser assim nomeada recebeu o nome de Xarayes, adotado pelos espanhóis, numa relação com uma nação indígena da região que tinha esse nome. Costa (1999, p. 22), em seus relatos sobre os séculos XVI e XVII, coloca que a planície passou a ser "descrita em textos e representada em mapas como a fabulosa "Laguna de los Xarayes" [...]. Para a autora, essa denominação sobreviveria até meados do século XVIII, enquanto que, no início desse mesmo

\footnotetext{
17 Este estudo foi publicado no artigo Capital Natural: Fonte de Bens e Serviços - O Caso do Pantanal, pelos pesquisadores Emiko Kawakami de Resende e Walfrido Moraes Tomás. ADM Artigo de Divulgação na Mídia, Embrapa Pantanal, Corumbá-MS, n. 94, p.1-3 dez. 2005.

${ }^{18}$ designação comum a várias plantas de diferentes gêneros e famílias nativas da América do Sul, ger. árvores com madeira dura e casca ricas em tanino, esp. as do gên. Schinopsis, da fam. das anacardiáceas, tb conhecidas como quebracho-vermelho- Dicionário Eletrônico Houaiss, 2001.
} 
século, os portugueses chamariam a região de "pantanal ou pantanaes", nome que prevaleceu.

Essas denominações estão relacionadas ao grau de conhecimento que espanhóis e portugueses tinham da região, como também evidencia a disputa que se travou pela ocupação da terra, pelas incansáveis buscas por pedras preciosas, minas de ouro, minas de prata e pela expansão das fronteiras. Pelo Tratado de Tordesilhas, firmado entre Espanha e Portugal no fim do século XV, a região do Pantanal não pertencia à Coroa Portuguesa e sim à Coroa Espanhola, sendo os espanhóis os seus primeiros colonizadores. Fazendo o caminho do sul para o norte, as tentativas de fixação dos espanhóis se deram de Assunção em direção às minas de ouro do Peru. Nesse percurso, fundaram alguns vilarejos que sucumbiram ao ataque de índios, sendo o de Santiago de Xerez, fundado em 1580, próximo ao rio Miranda, o mais atingido pelos indígenas (FERNANDES,1998, p. 78).

Os bandeirantes portugueses - nas primeiras décadas do setecentos fascinados pelo brilho do ouro, mesmo não tendo a facilidade que tinham os espanhóis para navegarem pelos rios Paraná e Paraguai, enfrentaram cerca de três mil quilômetros de rio, em canoas de tronco inteiriço, as ubás, vencendo significativos desafios (dentre eles cento e treze cachoeiras), com o objetivo de explorarem as minas de Mato Grosso. Estava selada a presença da cultura portuguesa naquela região, e com esta vinham também escravos negros e os primeiros freis (1998, p. 78).

Posteriormente, o povoamento da região do Pantanal recebe a influência dos paulistas, da expansão pastoril e da reconstrução fundiária. Vindo, em seguida, as invasões praticadas pelas pessoas interessadas em viver na região. Outro fator que contribuiu para a ocupação da região foi a decadência das minas de ouro em Cuiabá, que motivou a migração de cuiabanos, paulistas e portugueses para os campos nativos do Pantanal, propícios à criação de gado.

Nogueira (1989, p. 29) afirma que foi o ciclo da bivinocultura, o responsável pela instalação dos primeiros latifúndios, antes da Guerra do Paraguai. Observa ainda que [...] foi a fase da pecuária, associada à política de ocupação do solo, que oportunizou o efetivo povoamento da região e a implantação dos primeiros núcleos populacionais. 
Segundo a autora, foi muito importante, também, para o povoamento do Pantanal a migração de mineiros, paulistas, nordestinos e gaúchos. No final do século XIX e começo do século XX, historiadores rio-grandenses calculam em dez mil o número de gaúchos que vieram para a região.

O Pantanal também foi palco da Guerra do Paraguai, um acontecimento triste e vergonhoso para a América Latina que ocasionou um grande problema, do lado brasileiro, principalmente para os Estados vizinhos, vindo a região pantaneira a sofrer grande transformação a partir de então. Na época, o Paraguai era um país independente do domínio europeu. Desenvolvia-se politicamente sem ter o comércio exterior como eixo da vida nacional. Era o único país latino que não tinha mendigos, nem analfabetos e sua economia estava em pleno crescimento. Diante de tal situação, os europeus não escondiam sua preocupação, já que se configurava como um foco de resistência, como também pelo exemplo que essa experiência irradiava na região. Galeano (1976, p. 208) afirma que:

O comércio inglês não dissimulava sua inquietação, não só porque aquele último foco de resistência nacional no coração do continente era invusnerável, mas também, e sobretudo, pela força do exemplo que a experiência paraguaia irradiava perigosamente para os vizinhos. O país mais progressista da América Latina construía seu futuro sem inversões estrangeiras, sem empréstimos do banco inglês e sem as bênçãos do livre comércio.

Esse foi um dos principais motivos para que Brasil e Argentina fossem colocados contra o Paraguai e numa trama de provocações e enganos se fez 0 acordo argentino-brasileiro contra o Paraguai.

Segundo Galeano (1976, p. 209):

Foi uma carnificina, executada toda ao longo dos fortins que defendiam, de lado a lado, o rio Paraguai. O "orpbioso tirano" Francisco Solano López encarnou heroicamente a vontade nacional de sobreviver; o povo paraguaio, que não sofria guerra desde meio século antes, se imolou a seu lado.

[...] Quando finalmente o presidente paraguaio foi assassinado a bala e a lança na espessura do morro Corá, chegou a dizer: "Morro com minha pátria!", e era verdade. O Paraguai morria com ele. 
Do lado brasileiro, o estrago também foi grande para o Pantanal. As tropas inimigas não pouparam os povoados, nem as fazendas, que foram todas saqueadas, os rebanhos dizimados e os fazendeiros obrigados a fugirem para Cuiabá, levando apenas o essencial. Porém, terminada a Guerra (1870), o Pantanal, após grave crise - com propriedades e povoados abandonados ou destruídos - voltou ao domínio dos brasileiros. Algumas famílias, empenhadas na recuperação de seus bens, voltaram à região e recomeçaram tudo.

Tempos depois, surgiram inúmeras fazendas provenientes da redistribuição das terras entre os herdeiros dos antigos proprietários. Essas fazendas posteriormente foram redivididas. Hoje, esses herdeiros, que se criaram longe de suas propriedades, estão vendendo suas terras para grandes empresários de outros Estados, os quais não têm a mesma relação com a região de quem vive aqui. Estão desmatando e queimando o solo pantaneiro e criando com isso um problema ambiental.

A qualidade comprovada das pastagens naturais pantaneiras atraiu também os investidores estrangeiros: [...] capitalistas latinos e europeus passaram a investir na pecuária pantaneira, intensificando-se a imigração de argentinos, italianos e ingleses (NOGUEIRA, 1989, p. 30).

A construção da Estrada de Ferro Noroeste do Brasil se deu, dentre outros aspectos, em razão da preocupação das autoridades brasileiras com a entrada e expansão desse capital estrangeiro no Pantanal. Nos primeiros anos do Século XX (1914), tem início o projeto que iria contribuir para o surgimento de cidades ao longo dos trilhos, bem como para arrefecer 0 interesse dos investidores estrangeiros. Arruda (2001, p. 01) afirma:

Os trilhos da Estrada de Ferro Noroeste do Brasil tem em Mato Grosso do Sul um significado muito especial. A construção de uma linha ferroviária em princípios do século $X X$ foi um dos fatores determinantes da formação histórica de nosso estado, aplainando 0 terreno para uma ocupação mais intensiva e expressiva desta parte da fronteira Oeste brasileira.

E completa:

Além da gente que veio atrás dos trilhos, primeiro para assentá-los e depois para percorrê-los e fixar-se, e aqui deixar suas raízes, chegaram também novos impulsos de desenvolvimento econômico, 
usos, costumes e culturas diversas acabando por formar a sociedade plural que hoje caracteriza o sul-mato-grossense.

A ferrovia cumpriu, dessa forma, seus objetivos estratégicos e econômicos e ligou o Estado ao Porto de Santos, possibilitando o surgimento de novos núcleos populacionais e o avanço do desenvolvimento no interior do país. Segundo Weingartner (1995, p. 33) a estrada de ferro no sul de Mato Grosso [...] atrairia para - Brasil o comércio da Bolívia e do Paraguai, impedindo assim a expansão econômica Argentina junto aqueles países.

Por outro lado, a estrada de ferro trouxe doenças e desespero a muitos povos da região. Além das alterações nos costumes, a ferrovia provocou os conflitos de terra, exercendo, segundo Weingartner (1995, p. 36), uma força contraditória: ao mesmo tempo que provocou a fragmentação de alguns latifúndios, possibilitou a formação de outros, principalmente nas proximidades das cidades exportadoras de gado ou à margem de seus trilhos. A ferrovia contribuiu para o acirramento dos conflitos fundiários nos ervais e Campos de Vacaria, situação que iria contribuir para a futura criação do Estado de Mato Grosso do Sul.

Os índios são fundamentais na história da colonização e povoamento do Pantanal. Como afirma Proença (1992, p. 24) são eles que abrem a história

[...] sejam quais forem os caminhos percorridos pelos homens préhistóricos para chegarem ao Pantanal, o certo é que os índios legaram a terra muitas contribuições, até hoje manifestadas na dança, música, culinária e nas demais expressões culturais do folclore pantaneiro.

E não só esses aspectos compreendem a participação dos aborígines. Foram eles que iniciaram a história da ocupação humana em terras pantaneiras, em harmonia com o meio ambiente e desfrutando de uma vida livre como senhores da terra. Adaptados ao longo dos rios e nas terras circundantes formaram grupos tribais e lingüísticos, cada qual com seus costumes, envaidecidos das boas qualidades de caçadores em uma região de muitos pássaros e outros bichos (PROENÇA, 1992, p. 24).

As nações que habitavam o Pantanal sofreram muito com a chegada do branco. Esse convívio trouxe alterações em seus costumes, descaracterizando muito a sua cultura. Muito embora tenham resistido bravamente no início da ocupação, 
principalmente os Paiaguás com suas canoas e os Guaicurus com seus cavalos, tiveram suas tribos enfraquecidas nos enfrentamentos com os colonizadores. Isso resultou em uma população reduzida, onde poucos sobrevivem, na sua maioria, em contato com a sociedade envolvente. Nogueira (1989, p. 28) afirma que eles estão:

integrados à sociedade branca, por meio de bons empregos ou do casamento com "civilizados". No entanto, a prática comum continua sendo a marginalização e os terena, por exemplo, sobrevivem como agricultores ou peões nas fazendas da região, sem outra saída, senão a paulatina aculturação.

Os povos indígenas que vivem atualmente em Mato Grosso do Sul compreendem, segundo José da Silva (2004), 09 (nove) etnias: Atikum, GuaraniKaiowá, Guarani-Ñandeva, Guató, Kadiwéu, Kamba, Kinikinau, Ofaié e Terena. Destas, vivem na região do Pantanal as dos Guató, Kadiwéu, Kamba, Kinikinau, Terena e Atikum. Cada um destes povos se apresenta de forma diferenciada nos aspectos culturais e históricos: os Guató são senhores das águas, conhecidos como índios canoeiros. Pertencem ao tronco Macro-jê e foram considerados extintos até a descoberta de um expressivo grupo, vivendo na cidade de Corumbá-MS, sem que tivesse sua identidade indígena reconhecida. Segundo Cabral (2002, p. 36), [...] foi, com certeza, uma estratégia de sobrevivência utilizada quando ser índio era mais difícil do que ser outro grupo não-branco.

Afirma o autor que a maioria das crianças e jovens guató desconhece a língua materna, ainda preservada pelos anciãos. É o grupo mais isolado dentro do Estado, pois a ilha Ínsua, onde vivem é de difícil acesso - a viagem pode levar até dois dias de barco rio acima - dificultando o contato.

Os Kadwéu são chamados de Mbayá e classificados lingüisticamente como Gaicuru. Arredios ao convívio com o branco, habitam as terras da Reserva Indígena Kadwéu, no município de Porto Murtinho conhecida popularmente como campo dos índios, onde, de acordo com Nogueira (1989, p. 28) não cessam os litígios com os posseiros e os criadores de gado.

Cabral (2002, p. 39) afirma que

[...] senhores de uma sociedade complexa, os Kadwéu escravizaram membros de outros povos indígenas, vencidos na guerra, mas, também, tiveram a adesão voluntária de muitos, [...] esta condição privilegiada fez do povo Kadwéu um insterlocutor qualificado para as questões de segurança da colônia. 
São os que detêm as melhores condições financeiras, conseqüência da estabilidade conquistada pela posse da terra, desde o século XIX.

Os terena habitam um amplo território que vai do município de Miranda ao de Sidrolândia, passando por muitos outros: Aquidauana, Anastácio, Dois Irmãos do Buriti, Nioaque, Bonito e Rochedo. Estão distribuídos nas aldeias: Lalima, Cacheirinha, Babaçu, Pilad Rebuá, Argola, Passarinho, Moreira, Brejão, Taboquinha, Água branca (município de Aquidauana), Água Branca (município de Nioaque), Córrego do Meio, Buriti, Água Azul, Limão Verde, Córrego Seco, Lagoinha, Imbirussú, Bananal, Colônia Nova, Ipegue, Jaraguá, Bálsamo e Aldeinha (urbana) além daqueles que hoje vivem desaldeados (CABRAL, 2002, p. 45).

Atualmente, constituem-se na segunda maior população indígena do Estado de Mato Grosso do Sul e encontram-se perfeitamente aculturados. Segundo Cabral (2002, p. 47), em uma situação de intenso contato, dominaram a vivência nos centros urbanos: primeiramente em Aquidauana e Anastácio, depois em Miranda e Campo Grande.

Nesse convívio, atuaram inicialmente no comércio e, em seguida, partiram para a política, atuando há, pelo menos sete legislaturas, como vereadores em Aquidauana, tanto filiados a partidos situacionistas, quanto a partidos de oposição. Estão presentes ainda na Administração Regional da FUNAl de Campo Grande, bem como na sede, em Brasília.

Essa etnia tem um grupo de professores habilitados para o magistério no ensino fundamental, atuando nas aldeias e um grande número de acadêmicos cursando as licenciaturas, nas diversas Universidades públicas e particulares do Estado.

Pertencentes à família lingüística Aruak, os Kinikinawa vivem atualmente espalhados em algumas aldeias do lado ocidental de Mato Grosso do Sul, apresentando sua maior concentração na Aldeia São João, ao sudeste do território indígena Kadiwéu.

Culturalmente, tanto os terena, quanto os Kadwéu e os Kinikinawa notabilizaram-se com o trabalho de artesanato em barro. A cerâmica kadwéu se constitui em uma das melhores cerâmicas indígenas brasileiras, tanto pela forma policromada e queimada, quanto pela decoração - o geometrismo em dois estilos diferentes. Há os padrões geométricos, abstratos, usados principalmente na pintura decorativa, e o estilo figurativo, no qual geralmente há a intenção de relatar algum 
acontecimento importante para a tribo. Essa arte rendeu a um grupo de mulheres da tribo um premio internacional, na Alemanha, onde ganharam um concurso para a escolha da decoração de um edifício e de seu entorno (CABRAL, 2002, p. 43).

A cerâmica terena ${ }^{19}$ é muito bonita. Suas peças são modeladas manualmente com a técnica de roletes (cobrinhas). Atualmente alguns se valem do torno de oleiro (sem motor elétrico). Utilizam em seus trabalhos argilas de diversas cores dependendo da região: preta, branca e vermelha e amarela. Os grafismos usados pelos Terena são basicamente o estilo floral, pontilhados, tracejados, espiralados e ondulados. O acabamento das peças é feito com ferramentas rudimentares: seixos rolados, espátulas, ossos, entre outros.

Os Kinikinawa desenvolvem também sua arte com a cerâmica, em uma maior utilização da argila, tornando os objetos mais espessos e pesados. Elaborada pelas mulheres, essa arte dá continuidade a uma antiga tradição Guaná. Escolhida, além de outros, como símbolo de diferenciação do grupo em relação aos Kadiwéu a despeito de ser inspirada nos desenhos da cerâmica Kadiwéu - e outros indígenas, a cerâmica Kinikinau desempenha um importante papel como sinal diacrítico. O material tem sido comercializado, sobretudo, na cidade de Bonito (JOSÉ DA SILVA e SOUZA, 2005, p.01).

Os índios Kamba são de origem boliviana e vivem no município de Corumbá, onde conseguem viver bem adaptados, mantendo suas características culturais. Os Atikuns constituem um grupo pequeno que, em razão de divergências com seu grupo de referência, situados em Pernambuco, fixaram-se em Nioaque, próximo à aldeia Brejão, dos terena (CABRAL, 2002, p. 63).

Dessa forma, na maior planície alagada do planeta e terceira maior reserva ambiental do mundo, constrói-se uma mistura étnica de ritmos, de visões de mundo, de linguagens entre índios, negros e brancos que se constitui na identidade dessa região. [...] o Pantanal é um mundo de lendas e mitos que percorrem os milhares de quilômetros quadrados, num mistério presente nas músicas regionais, rituais indígenas e histórias de peões pantaneiros (xaraes - on-line, 2006, p.2).

19 As informações sobre a cerâmica Terena e Kinikinawa foram obtidas no site: 'http://www.noticias.ms.gov. br/index.phph? acesso em 19/042007. 


\subsection{O PANTANEIRO}

O homem pantaneiro ${ }^{20}$ que há muitos anos habita o Pantanal aprendeu a conviver com um mundo inundado, úmido ou seco. É um homem simples, calmo, acostumado à solidão e ao isolamento, mas não deixa de lado a solidariedade: está sempre pronto a receber, a informar a servir de guia, a explicar sobre animais e águas e a contar seus causos ${ }^{21}$. É antes de tudo um forte que, atuando em uma área cheia de adversidades, está integrado a esse contexto. Com seu chapéu de palha de abas largas na cabeça (o de feltro não é apropriado para as altas temperaturas do verão pantaneiro), calças jeans surradas e camisa ou camiseta de mangas curtas e facão no cinturão, trabalha com o gado, sempre montado em seu cavalo.

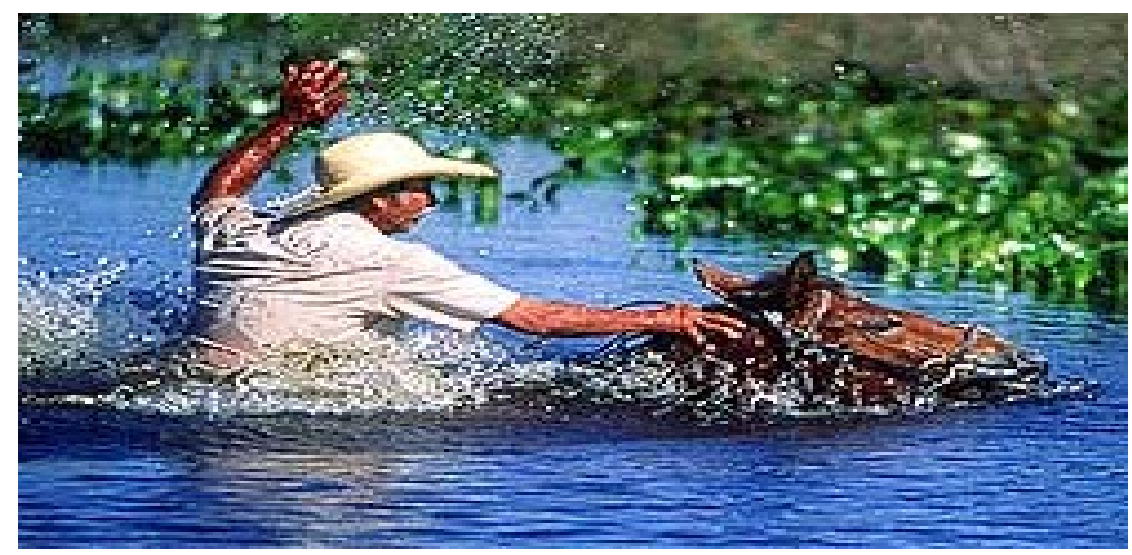

Figura $15-$ Vaqueiro

Conhecedor da região, o pantaneiro sabe os perigos que enfrenta, mas sabe respeitar esse espaço e preservá-lo. Segundo Ravazzani (geocities.com - 2007, p. 3), esse homem [...] recebeu dos indígenas Guaranis, Payaguás e Guatós, a agilidade física e o respeito à natureza, a qual se encontra praticamente inalterada com mais de 200 anos de ocupação e exploração econômica.

Desenvolve um ritmo próprio de trabalho e cria suas próprias ferramentas.Com técnica própria para trabalhar artesanalmente o couro, confecciona

${ }^{20}$ Entende-se, portanto, por homem pantaneiro, neste contexto, o elemento nativo do Pantanal ou aquele que nele vive há mais de vinte anos, compartilhando hábitos e costumes típicos da região, assimilados pela força do convívio diário com os mesmos (Conforme NOGUEIRA, 1989, p. 31).

${ }^{21}$ Os peões possuem uma imaginação fértil para inventar as grandes mentiras e uma predisposição inata para colocar apelidos nos outros. 
sua própria montaria e seus complementos como o laço pantaneiro, as peiteiras e cabeçadas para os cavalos, afinal - antigamente, no Pantanal - um pantaneiro com uma boa montaria era considerado um bom partido para se namorar e casar.

Ligado principalmente às atividades da pecuária que são predominantes no Pantanal, tanto do ponto de vista histórico-cultural, quanto sócio-econômico, o pantaneiro desempenha várias funções inerentes à lida com o gado, como a de gerente ou capataz, de peão ou vaqueiro. Atualmente, com o desenvolvimento do ecoturismo na região, começam a surgir outras funções como a de guia turístico e motorista-safari.

Essa vida ligada estreitamente à natureza e ao mundo ao seu redor, se reflete na sua alimentação de três refeições diárias à base de arroz, mandioca, farofa, feijão, carne e peixe em abundância e pouca ou nenhuma verdura. $O$ trabalho que exerce, diariamente, sempre no lombo do cavalo, exige que se levante ainda de madrugada - ao clarear do dia, como diz — tome seu mate-quente, arreie sua montaria, coma o quebra-torto (farofa, chá, mandioca ou arroz-carreteiro). Carregue também a matula ${ }^{22}$ e o tereré, ou mate-frio, que leva num sapiquá ${ }^{23}$ com a guampa ${ }^{24}$, a bomba e a erva-mate, para tomar antes do almoço e no meio da tarde.

Outra peculiaridade do pantaneiro é o seu conhecimento e uso das plantas. Longe dos médicos e das farmácias o pantaneiro tem as suas receitas medicinais para curar as doenças, as machucaduras e os ferimentos causados pelo ataque dos animais selvagens. Com observa Nogueira (1989, p. 31)

[...] a natureza, como dizem os peões, é uma clínica. Quase todas as ervas e plantas, tanto as caseiras, quanto às nativas, são um "santo remédio" e, às vezes, transformam-se em coisas sagradas, tal é a crença no poder de cura, através de remédios extraídos não só delas, como também da graxa de bichos como peixes, sucuri, capivara e jacaré.

Nesse espaço em que atua, o pantaneiro compartilha de uma estrutura social que mostra a oposição entre aquele que tem e aquele que não tem. De um lado está o poder econômico, acumulado nas mãos dos donos das terras e do outro a pobreza dos peões, habitualmente itinerantes. Segundo Nogueira (1989, p. 33)

${ }^{22}$ Comida que o peão leva para comer no campo, quando precisa passar o dia todo lá, sem voltar para o almoço e constitui-se em uma carne oreada (exposta ao sol e ao ar = carne de sol), frita, misturada com farinha de mandioca.

${ }^{23}$ saco grosseiro de viajantes; picuá. Conf. Dicionário Eletrônico Houaiss, 2001.

${ }^{24}$ chifre talhado em forma de copo ou vasilha para líquidos; guampo. Conf. Dicionário Eletrônico Houaiss, 2001. 
[...] a coexistência de dois tipos fundamentais de identificação cultural define a configuração do universo sociocultural pantaneiro, onde, de um lado, ressalta-se a cultura refinada do patrão, que valoriza a tradição burguesa, com seus rituais e convenções; de outro, a cultura rústica do peão, que se apóia na simplicidade e na espontaneidade de um saber e de um fazer empíricos, transmitidos, oralmente, através de gerações.

Entretanto, em outras épocas, a situação era diferente. Principalmente os primeiros fazendeiros tinham o mesmo grau de instrução dos empregados, bem como hábitos e costumes semelhantes. Esse fato contribuía para o estabelecimento de uma interação entre patrão e peão — ambos acostumados à vida simples — que compreendia laços de cordialidade e amizade muitas vezes solidificados pelas relações de compadresco.

Dentro desse contexto social, a extensão das fazendas e o conforto de suas sedes é um aspecto que chama a atenção. Com uma área que muitas vezes se iguala à de pequenos países europeus, muitas fazendas têm sedes com verdadeiras mansões que lembram aquelas do período colonial.

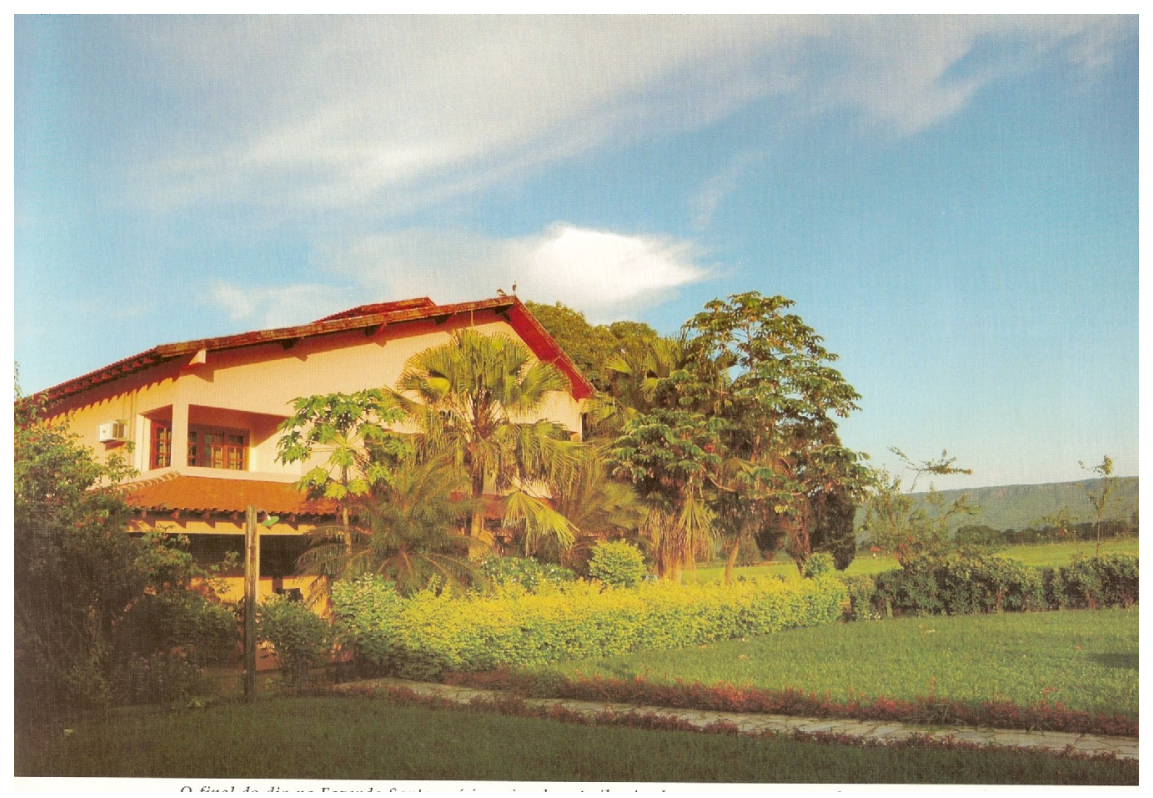

Figura 16 - Sede da Fazenda Santana - Município de Aquidauana - MS 


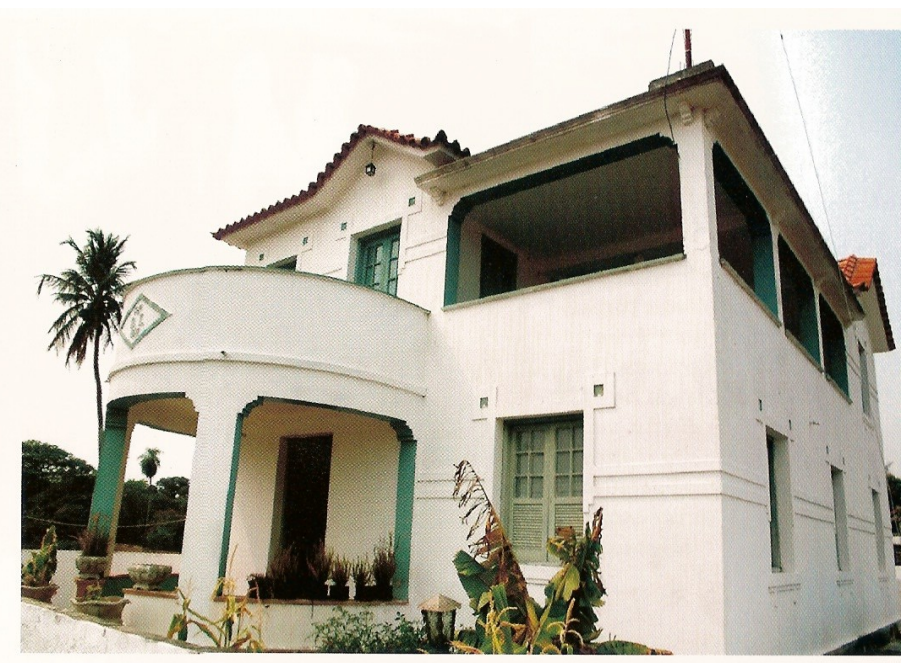

Figura 17 - Sede da Fazenda Dois Irmãos - Município de Corumbá -MS

A maioria dessas fazendas é administrada pelos gerentes ou capatazes, pessoas de confiança do fazendeiro, encarregadas de supervisionar o trabalho dos demais empregados e dar as ordens ao capataz de campo que, por sua vez as passa aos peões campeiros. $O$ peão praieiro $^{25}$ geralmente presta contas de suas atividades à mulher do gerente ou do capataz. As fazendas, que são grandes empresas, mantêm uma organização diferenciada com seus superintendentes, diretores e gerentes que não residem nelas permanentemente.

Dessa maneira, os aspectos socioculturais do latifúndio materializam-se e apoiam-se no poder econômico do proprietário de terras que - na maioria das vezes vive longe de suas terras, nos grandes centros urbanos - mas faz-se representar pela figura do gerente ou do capataz. Já os aspectos socioculturais do peão ou ex-peão, geralmente, analfabeto ou semi-analfabeto, apóiam-se no estatuto da pobreza e da dependência econômica, pois esses trabalhadores, por exercerem atividades que dispensam especialização, constituem a mão-de-obra de baixo custo, fato que, geralmente, Ihes impede qualquer tipo de ascensão social (NOGUEIRA, 1989, p. 33).

\footnotetext{
${ }^{25}$ Peão praieiro é aquele responsável pelo trabalho externo (do pátio) da sede.
} 


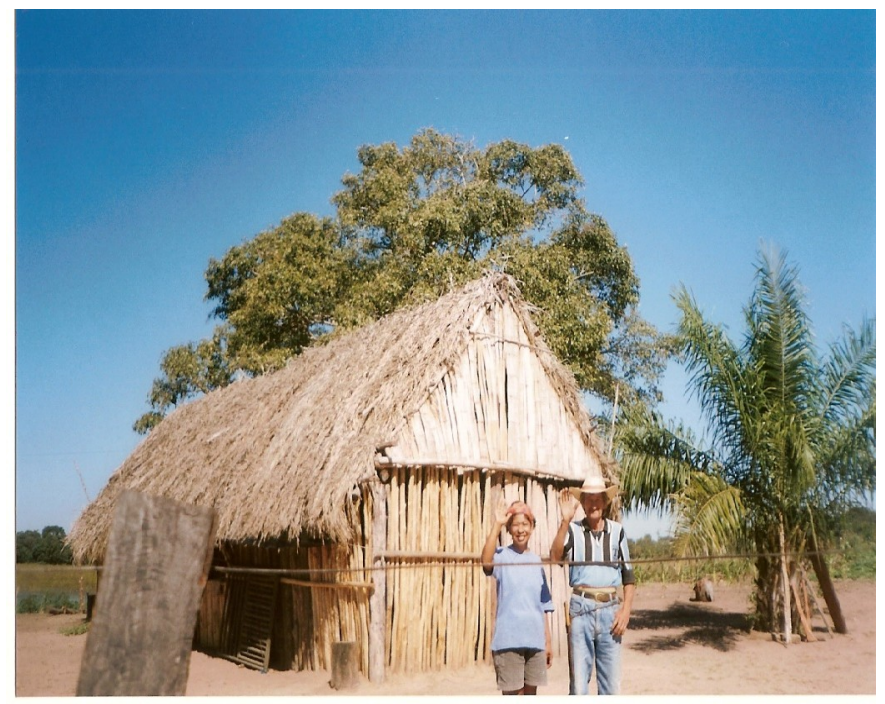

Figura 18 - Casa de pau-a-pique

Atualmente há, por parte dos patrões, muita diferença no tratamento com os peões. Existem os que oferecem boa casa, que fornecem a carne de graça, os alimentos, mas há os que não dão nada além do pequeno salário e um lugar, nem sempre confortável, para morar São relações formais, havendo acentuado distanciamento entre eles. Segundo Nogueira (1989, p. 34)

[...] muitos peões não conhecem o proprietário; só tratam com o gerente ou o capataz de campo. As grandes propriedades possuem, normalmente, escritórios nas sedes dos municípios, onde se localizam, ou na capital do Estado. Por isso, mensalmente, grande número de peões se deslocam até a cidade, a fim de receber o salário e efetuar as compras do mês, ou "fazer o rancho". Alguns deles, contudo, preferem suprir suas necessidades de consumo nos armazéns da fazenda, onde efetuam as compras semanais ou mensais. No fim do mês, o valor das compras é descontado do salário. 


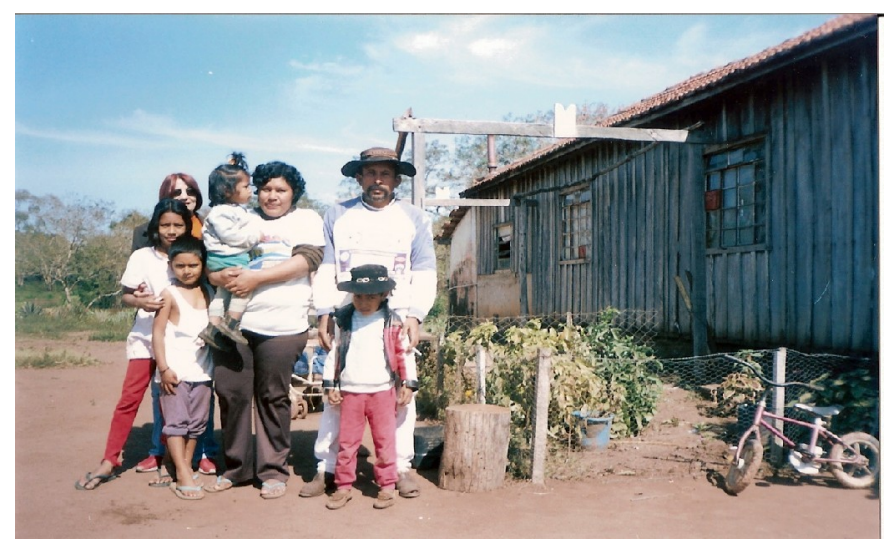

Figura 19 - Casa de madeira

Nas fazendas, alguns peões pantaneiros optam por morar junto à sede, com relativo conforto, nas vilas ou ranchadas ${ }^{26}$, enquanto outros preferem os lugares mais afastados como, por exemplo, os retiros ${ }^{27}$, onde muitas vezes vivem em choupanas rústicas, cobertas de palha, chão de terra batida e dormem em redes. Há ainda aqueles que optam em morar sozinhos e mandar a família para a cidade, quando os filhos encontram-se em idade escolar, pois querem que estes estudem, para não levarem a mesma vida sacrificada dos pais.

Grande conhecedor das plantas, como já referido, o pantaneiro mantém com elas um relacionamento diário, tanto no uso medicinal, quanto nas orientações de locomoção e em outros fatores relacionados às suas atividades. Utilizando-as como orientação na sua locomoção pelo campo, ele observa, por exemplo, como marco uma piúva ${ }^{28}$ ou um capão que, ao recém-chegado, parece igual a centenas de outras. Sabe que onde tem, caeté $^{29}$, o carro atola, onde tem embaúba ${ }^{30}$, dá bom poço; onde tem acuri ${ }^{31}$, pode ter porco. Quando a fome ou a sede aperta, alimenta-

${ }^{26}$ Conjunto de ranchos de peões: grupo de ranchos. Conf. Nogueira (1989, p.254).

${ }^{27}$ Esses retiros são locais de moradia distantes da sede, necessários para um melhor controle da criação.

${ }^{28}$ Ipê comum. Conf. Dicionário Eletrônico Houaiss, 2001.

29 designação comum a diversas ervas, da família das marantáceas, nativas do Brasil, cultivadas como ornamentais, por suas folhagens e/ou inflorescências; caetê, caité. Conf. Dicionário Eletrônico Houaiss, 2001.

${ }^{30}$ designação comum às árvores do gênero Cecropia, da família das cecropiáceas, com troncos fistulosos, grandes folhas peltadas, flores em espigas e pequenos frutos nuciformes. Suas folhas são usadas como lixas, os brotos e frutos são especialmente procurados por preguiças, e dos troncos, freqüentemente habitados por formigas, extraem-se polpa para papel e fibras e fazem-se calhas e pequenos objetos. Conf. Dicionário Eletrônico Houaiss, 2001.

${ }^{31}$ É um tipo de palmeira (Attalea phalerata); nativa do Brasil (Amaz, SP, C - O), Bolívia e Paraguai, os frutos são apreciados pela fauna silvestre. Conf. Dicionário Eletrônico Houaiss, 2001. 
se de frutas nativas que podem amenizar a dura jornada: ananás ${ }^{32}$, araçá $^{33}$, ariticum $^{34}$, bocaiúva ${ }^{35}$, entre outros (pantanalms - on-line - 2004, p. 5).

A lida com o gado, nem sempre manso, os rodeios, a doma, a condução das boiadas, fazem do vaqueiro do Pantanal um trabalhador quase sempre ativo e atento a todas as transformações do habitat. Por outro lado, no trabalho artesanal com o couro, o contato, mesmo que breve, com turistas e visitantes, adota comportamentos diferentes dos esteriótipos negativos de que tem sido alvo e que Ihe atribuem como características a ingênuidade, a timidez, a preguiça e o jeito arredio, calado.

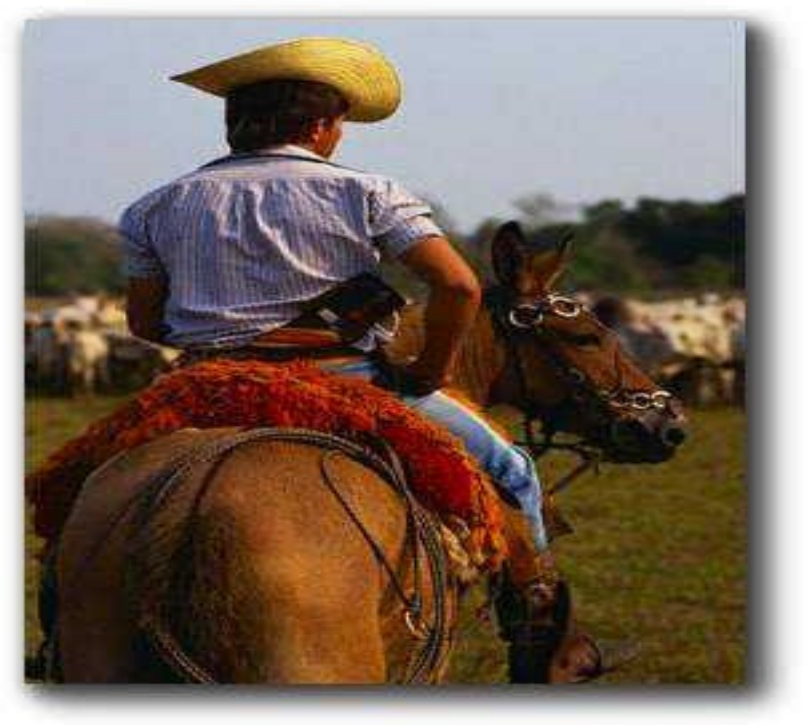

Figura 20 - Peão campeiro

\footnotetext{
32 designação comum às plantas do gên. Ananas, da família das bromeliáceas, nativas da América tropical. De folhas dispostas em roseta, geralmente com espinhos, que fornecem fibra sedosa, e fruto múltiplo, sincárpico, composto de até 200 bagas carnosas ao redor de uma haste e coroado por uma roseta de folhas; possui propriedades medicinais digestivas, supurativas e é usado no tratamento de afecções pulmonares. Conf. Dicionário Eletrônico Houaiss, 2001.

${ }^{33} \mathrm{O}$ fruto das árvores dos gênero Psidium e Campomanesia, com o tronco malhado e frutos bacáceos, semelhantes aos da goiabeira (Psidium guajava) e geralmente comestíveis; araçareiro, araçazeiro, araçoeiro. Conf. Dicionário Eletrônico Houaiss, 2001.

34 Árvore de até $10 \mathrm{~m}$ de altura, com tronco de até $35 \mathrm{~cm}$ de diâmetro, com casca rugosa, castanhoacinzentada e galhos ferrugíneo-tomentosos com lenticelas conspícuas nas partes mais tenras. Possui copa globosa, com densa folhagem de coloração verde-clara. Suas folhas são simples, alternas, de consistência papirácea, com nervuras proeminentes na face abaxial, medem de 8 a 12 $\mathrm{cm}$ de comprimento pr 3 a 5,5 cm de largura. São obovadas, com ápice de forma bastante variada e base cuneada ou aguda. A face abaxial é coberta de pêlos eretos, curvos ou crespos. Site;

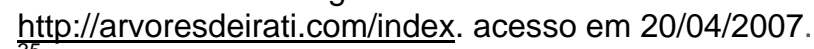

${ }_{35}$ Palmeira de até 7 (Acrocomia mokayayba), nativa do Paraguai e do Brasil (MT e MS), com estipe liso, frutos de polpa comestível, amarela e doce, com propriedades expectorantes. Conf. Dicionário Eletrônico Houaiss, 2001.
} 
À primeira vista pode parecer uma pessoa de pouca conversa, mas com voz baixa, aos poucos, vai contando suas aventuras e os "causos" de assombração e enterro, atribuindo às fazendas conhecidas um ou dois desses "causos". Supersticioso, o homem pantaneiro acredita, como observa Nogueira (1989, p. 37),

[...] tanto nos agouros do canto da coruja, do anu-preto, da macauã, como nos azares que o encontro com um tamanduá-bandeira, na estrada, pode trazer ao viajante.Crê, também, nas boas-novas anunciadas pela presença do beija-flor, que anuncia a chegada de visitas.

Além da superstição com aves e animais, costuma cultivar — na frente das casas - as plantas que protegem contra a inveja e o mau-olhado, como guiné, espada-de-são-jorge, jurema, rosa-menina, arruda.

Muito embora trabalhe duro, de sol a sol, o peão pantaneiro não tem muitas opções de lazer, a não ser uma partida de futebol ou a visita, aos domingos, aos vizinhos das fazendas mais próximas para uma boa conversa. Segundo Nogueira (1989, p. 38), [...] as grandes festas, que duravam vários dias, acompanhadas de churrasco, mandioca, tereré, carreiradas e bailes só existem, hoje, na memória dos mais velhos.

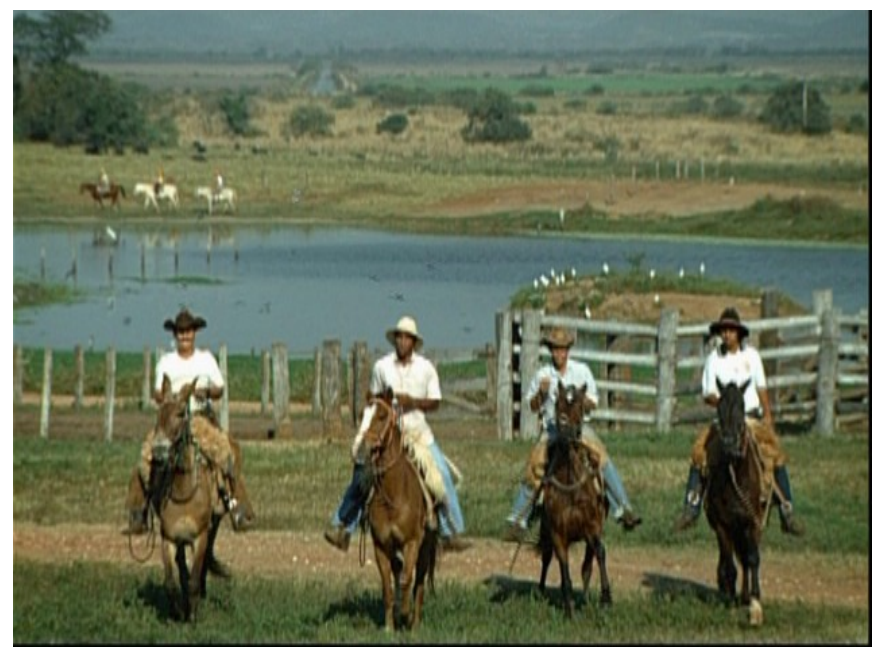

Figura 21 - Peões pantaneiros e suas montarias 
Atualmente, mesmo as festas dos santos preferidos dos fazendeiros não se realizam mais. De todos, o que tem a comemoração garantida é São Sebastião tido como padroeiro dos criadores - que protege contra a doença, a peste e a guerra.

O rádio e a televisão, presentes hoje na vida do peão pantaneiro, trazem as novidades em relação à música, aos filmes, às novelas, mas, mesmo assim, a preferência é pelas músicas e danças que mostram a forte influência paraguaiogurani, gaúcha e Argentina. O que mais se ouve, se dança e se canta são a polca paraguaia, o xamamé, o vanerão e o rasqueado.

A maioria dos filhos dos peões diverte-se com brinquedos construídos com os próprios recursos da região, como construção de curral de brinquedo, castelos de areia, casinha. Os meninos brincam com a funda e o bodoque, além de, juntamente com as meninas, nadar nas baías, andar a cavalo, brincar de pegador, de escondeesconde, de queimadas e outras tantas brincadeiras. Entretanto hoje, com a mídia televisiva no interior das casas desses peões, as brincadeiras começam a mudar com a presença de brinquedos adquiridos na cidade.

Esse é o pantaneiro que, diante das intempéries do espaço que habita, cria soluções e alternativas para as situações que surgem, principalmente a das cheias, momento em que não se tem nada a fazer a não ser esperar as águas baixarem. Como afirma Nogueira (2002, p. 31), [...] pode-se dizer que o pantaneiro é, ao mesmo tempo, um botânico, um zoólogo, um astrônomo, um geógrafo acostumado à leitura semiótica da natureza, com a qual aprendeu a conviver, no dia-a-dia. 
Carrego meus primórdios num andor.

Minha voz tem um vício de fontes.

Eu queria avançar para o começo.

Chegar ao criançamento das palavras.

Lá onde elas ainda urinam na perna.

Antes mesmo que sejam modeladas pelas mãos.

Quando a criança garatuja o verbo para falar o que não tem. Pegar no estame do som.

Ser a voz de um lagarto escurecido.

Abrir um descortínio para o arcano.

(Manoel de Barros, Livro sobre Nada, p. 47) 


\title{
CAPÍTULO II
}

\section{ANÁLISE DO DISCURSO: UM POUCO DA HISTÓRIA}

\author{
A Análise do Discurso ${ }^{36}$ (AD) é uma disciplina que surgiu na França, na \\ década de 60, com um percurso histórico que, segundo os estudiosos, é pontuado \\ em 3 (três) fases ${ }^{37}$ distintas. Muito embora o foco nesta pesquisa seja a AD hoje, \\ para que se possa ter uma idéia do todo, iremos fazer uma breve retomada desse \\ percurso, falando um pouco dessas fases no seu aspecto atual.
}

Ao final dos anos 50 e década de 60, a predominância, no campo dos estudos da linguagem, era da conjuntura estruturalista de vertente saussuriana, que preconizava ser a língua o verdadeiro objeto da Lingüística. Considerado por Benveniste (1991, p.35) "o homem dos fundamentos", Saussure defendeu o princípio de que tudo na linguagem é formado de duas partes, "[...] tudo traz a marca e o selo da dualidade opositiva" (BENVENISTE, 1991,p. 43), como por exemplo: dualidade articulatória/acústica, língua/fala; sincronia/diacronia, etc [...]", 38 sendo que, cada uma dessas partes só adquire valor em uma relação opositiva com a outra. Essa dualidade constituiu o sistema que possibilitou à lingüística o status de ciência piloto das ciências humanas.

É o período de apogeu do estruturalismo, sendo a Lingüística - enquanto ciência piloto - compreendida como aquela que conferia cientificidade às disciplinas vizinhas. A mesma dualidade que conferiu à Lingüística o status de ciência piloto serviu para destacar como objeto da ciência lingüística as noções de "língua" e de "sincronia", em detrimento da "fala" e da "diacronia". Segundo Brandão (2002, p. 01), embora Saussure 39 "reconheça que língua e fala sejam recortes diferentes do mesmo objeto, opta pelo campo da língua porque categorizável, enquanto a fala, situada no nível da concretude, não”.

${ }^{36}$ É importante esclarecer que estamos tratando especificamente da chamada Escola Francesa de Análise do Discurso.

${ }^{37}$ Os estudiosos que apontam essas três fases tomam por base a proposta do texto de Pêcheux: "A Análise de Discurso: três épocas (1983)".In: GADET,F. e HAK,T.(Orgs) Por uma Análise Automática do Discurso- Uma introdução à obra de Michel Pêcheux. Tradutores Bethânia S. Mariani...[et al.]. 3 ${ }^{a}$ edição. Campinas - SP: Editora da UNICAMP, 1997, p. 311.

${ }^{38}$ Este aspecto e outros sobre a obra de Saussure são encontrados no artigo: Saussure após meio século. In: BENVENISTE op. cit, p. 34-49

${ }^{39}$ Procurando, especialmente, demarcar especificamente o campo da ciência sincrônica da língua, para o mestre genebrino, diacronia e fala faziam parte de outro campo científico, passível de ser definido por uma outra ciência e não seria explorada, naquele momento. Conf. Brandão, op. cit. p.01. 
Segundo Pêcheux (1997, p. 62-63), o estudo da linguagem que antes do período saussureano buscava o estatuto de ciência da expressão e dos meios dessa expressão ${ }^{40}$, procurando refletir os fenômenos de grande dimensão, a partir das idéias do mestre genebrino, curvou-se ao estruturalismo que tinha como objetivo "estudar a estrutura do texto "nele mesmo e por ele mesmo"” (VILELA, 2005, p. 01), deixando de lado uma reflexão sobre sua exterioridade. Nessa perspectiva, a língua se constitui em um sistema fechado em si mesmo, desconsiderando suas relações com o mundo, ou seja, sua exterioridade.

Entretanto, é justamente o fato de Saussure ter deixado de lado o que se ponderou ser do "domínio da fala" que, na segunda metade do século XX, mais especificamente a década de 60 , mobilizou vários estudiosos ${ }^{41}$ a realizarem uma releitura do estruturalismo. A crítica que pesava sobre a conjuntura estruturalista saussuriana consistia no fato de que, deixando de lado o estudo da fala e da diacronia, Saussure rejeitou a concepção de linguagem enquanto atividade produzida por sujeitos falantes. Em seus debates e reflexões, os estudiosos buscam a compreensão da linguagem não só centrada na língua, mas também na sua exterioridade.

Além das idéias de Saussure, a releitura e o debate das obras de dois outros nomes constituem essa corrente filosófica, epistemológica e politicamente heterogênea da França: Marx e Freud. É dentro dessa conjuntura intelectual, filosófica e política que nasce a disciplina Análise do Discurso francesa.

Segundo Maldidier (1997, p. 16-17) o início da disciplina que posteriormente seria chamada Análise do Discurso de linha francesa, tem uma dupla fundação, com Jean Dubois e Michel Pêcheux. São dois estudiosos que, embora com formações e exercícios profissionais diferentes - Dubois, lingüista e lexicólogo envolvido com os

${ }^{40}$ Pressupor a língua como ciência da expressão significava estudar textos ou o conteúdo desses textos, pontuando questões pertinentes ao que, na prática escolar, denominamos, ainda hoje, de interpretação e/ou compreensão de textos (de que fala o texto? Quais as idéias principais do texto? $O$ que $o$ autor quis dizer com este texto?) e da atividade do gramático sobre as questões normativas ou descritivas ( $O$ texto $X$ está de acordo com as normas da língua na qual ele se expressa? Quais são as normas próprias a este texto?) - Conf. PÊCHEUX, op.cit., 1997, p.61 e SILVA, Ma da Conceição F. Os discursos do cuidado de si e da sexualidade em Claudia, Nova e Playboy. Campinas-SP: UNICAMP, 2003 (Tese de Doutoramento), p.98.

${ }_{41}$ Dentre esses estudiosos ressaltamos os franceses: Foucault, Derrida e Lacan que vão postular o sujeito ligado à linguagem e colocar em questão a transparência da língua e Althusser que não está interessado pela linguagem, defendendo que o sujeito é o da ideologia. Essa sua posição se explica pelo objetivo que tinha de renovar o marxismo e o materialismo histórico de Marx. Conf.. SILVA, op.cit., 2003, p. 94. Sobre Pêcheux vamos tratar adiante. 
debates em torno da Lingüística da época, em trabalhos que divulgavam o espírito de conquista desta, principalmente na elaboração de dicionários e na criação de revistas. Pêcheux, um filósofo envolvido com os debates em torno do marxismo, da psicanálise e da epistemologia ${ }^{42}$ - atuam (em uma intervenção focalizada nos anos 1968 - 1970) em um espaço comum: o do marxismo e da política, em que se aproximam por partilharem das mesmas convicções sobre a luta de classes, a história e o movimento social.

Embora os dois estivessem igualmente preocupados em pensar o discurso e os elementos para sua análise e compreendessem a nova disciplina como modo de leitura, as diferenças entre eles se configuram essencialmente em relação às posições que cada um assume em relação à teoria.

Os estudos de Dubois vão girar em torno do argumento de que a $A D$ deve romper com o comentário literário, substituindo a subjetividade do leitor pelo aparelho da "gramática". Desse modo, abandonando aspectos metodológicos da literatura com os quais discorda, o lingüista insere a nova disciplina no estudo dos importantes textos políticos da época, na França. Daí vem o principal objetivo do nascimento da AD: o estudo do discurso político. Segundo Maldidier (1997, p. 18), para ele, a instituição da $A D$ deve ser pensada dentro de um continuum, que compreende a passagem do estudo das palavras (lexicologia) para o estudo do enunciado (análise do discurso), vista como uma extensão natural da evolução da Lingüística.

Pêcheux, por outro lado, coloca a leitura como parte de uma teoria nãosubjetiva da linguagem, rompendo, dessa forma, com as práticas de explicação de texto e com os métodos estatísticos vigentes, naquele momento, nas ciências humanas (MALDEDIER, 1997, p.18).

O filósofo trata da "teorização de um objeto novo cujos procedimentos que permitem apreendê-lo, colocam em relação um dado estado das condições de produção e processos de produção do discurso" (BRANDÃO, 2002, p. 5). Este vai definir o discurso como sempre determinado e tomado em sua relação com a história. Para Pêcheux, a AD emerge de uma ruptura epistemológica com a ideologia dominante nas ciências humanas, de modo especial na psicologia.

${ }^{42}$ Pêcheux participava, de um grupo de estudos informal que se reunia na rua d'Ulm, liderado por Althusser, para refletir sobre questões teóricas relacionadas ao marxismo, à psicanálise e à epistemologia. 
Tomando o caminho oposto a uma filosofia idealista da linguagem que encontra "seu fundamento num terceiro posto [...] o efeito ideológico 'sujeito', pelo qual a subjetividade aparece como fonte, origem, ponto de partida ou ponto de aplicação" (MALDEDIER, 1997, p.131) e a transparência do sentido, Pêcheux (1975) postula o sujeito como constituído no discurso. Segundo Brandão (2002, p.06), a noção de sujeito em Pêcheux é determinada pelo lugar de onde fala e ele fala do interior de uma formação discursiva $(F D)^{43}$, regulada por uma formação ideológica $(\mathrm{FI})^{44}$, concebendo uma subjetividade assujeitada às coerções da FD e da $\mathrm{FI}$. Portanto, "um sujeito marcado por uma forte dimensão social, histórica, que na linguagem é balizada pela FD que define "o que pode e deve ser dito por um sujeito".

Apesar das posições teóricas divergentes, na instituição da $A D$, Dubois e Pêcheux concordam no que se refere às posições metodológicas, tendo em vista que ambos se fundamentam no método distribucionalista de Harris (1952), lingüista americano, que aponta a possibilidade de se ir além das análises confinadas à frase, ao tomar como unidade de análise o próprio enunciado.

Estudiosos - que antecederam Dubois e Pêcheux — foram decisivos nas tentativas de superação de uma lingüística restrita à língua: Roman Jakobson e Benveniste com suas pesquisas sobre a teoria da enunciação. Muito embora essas teorias tenham sido relevantes para a constituição do discurso, para Brandão (2002, p. 04)

[...] continuaram ainda presas à dicotomia saussuriana, assimilando a questão do discursivo à fala, com exclusão da história, concebendo o sujeito de forma idealizada, na sua unicidade e homogeneidade, como fonte criadora, origem do sentido, sentido entendido como transparência.

\footnotetext{
${ }^{43}$ Formação Discursiva: "conjunto de enunciados marcados pelas mesmas regularidades, pelas mesmas 'regras de formação' e se define pela sua relação com a formação ideológica, isto é, os textos que fazem parte de uma formação discursiva remetem a uma mesma formação Ideológica. A formação discursiva determina "o que pode e deve ser dito" a partir de um lugar social historicamente determinado. Um mesmo texto pode aparecer em formações discursivas diferentes, acarretando, com isso, variações de sentido" - BRANDÃO, Helena H.N. Introdução à Análise do Discurso. 3르 edição, Campinas-SP: Editora da UNICAMP, 1994, p.90

${ }^{44}$ Formação Ideológica: "é constituída por um conjunto complexo de atitudes e representações que não são nem individuais, nem universais, mas dizem respeito, mais ou menos diretamente, às posições de classe em conflito umas com as outras (Haroche et alii). Cada formação ideológica pode compreender várias formações discursivas interligadas." (BRANDÃO. op. cit, 1994, p.90).
} 
Assim, Dubois, juntamente com os lingüistas interessados na nova disciplina, e Pêcheux com os pesquisadores em ciências humanas que com ele refletiam sobre a questão - no conjunto das aproximações e divergências teóricas - instituíram, na segunda metade da década de 60, uma prática de Análise do Discurso na França.

Entretanto, no movimento da história, a $A D$, como toda teoria, recebeu muitas críticas importantes vindas de lingüistas, de pesquisadores de outras áreas, bem como dos próprios analistas do discurso. Segundo Maldidier (1997, p. 24):

\begin{abstract}
A $A D$ - por fora dos caminhos do que se designava como "sociologia da linguagem" ou "sociolingüística" - procurou construir um objeto, fornecendo os instrumentos operacionais para trabalhá-lo. Paradoxalmente, o que constitui a $A D$ é, por sua vez, o que a bloqueia: o fechamento do corpus discursivo, a homogeneidade produzida pelo corpus, a dissociação entre descrição e interpretação. A AD, de alguma maneira, repetiu na sua constituição as condições da fundação saussuriana do objeto da lingüística [...] A história da constituição da $A D$ pode, talvez, ser vista como uma amostra da história das ciências dentro de um domínio, onde a ruptura é sempre lugar de recobrimentos. $O$ que constituía a força da $A D$, enquanto acontecimento, era também o que a tornava insustentável. Era preciso, então, descompactificá-la.
\end{abstract}

Esses recobrimentos, essas falhas e as reconfigurações pertinentes à construção do objeto teórico da $\mathrm{AD}$, podem ser constatados, principalmente, no texto de Pêcheux: A Análise do Discurso: três épocas (1997, p. 311), que mostra uma síntese da $A D$ por ele elaborada. Podem ser constatados também em outras duas publicações de Pêcheux: no texto de Pêcheux e Fuchs, A Propósito da análise automática do discurso: atualização e perspectivas (1997, p. 163) que apresenta críticas pertinentes à AAD (1969) e propostas de reconfigurações e no livro, Semântica e Discurso - uma crítica à afirmação do obvio (1997a), que representa um outro momento de reflexão do autor, em que, através das reavaliações sobre certos conceitos, vai aprofundar alguns e refutar outros.

\title{
2.1 ANÁLISE DO DISCURSO - TRÊS ÉPOCAS
}

A expressão "Análise do Discurso: três épocas", como já referido, foi utilizada inicialmente por Michel Pêcheux como título de um de seus textos, que 
mostra o percurso histórico por que passou a AD por ele elaborada, desde sua emergência até o final da década de 80, mais ou menos. Atualmente, outros estudiosos, ao retomarem o percurso histórico da $A D$, utilizam a tripartição estabelecida por Pêcheux acrescida da contribuição de outros teóricos.

Consideramos, no entanto, que mais importante que essa divisão metodológica, é a reflexão que pode ser constatada neste percurso histórico por que passou a Escola Francesa de Análise do Discurso. Ao revelar os embates, as reconstruções e as retificações que marcaram a sua constituição teórica, a $A D$ traduz, em sua própria história, aquilo que motivou seu surgimento: a ruptura com o conceito científico de verdade absoluta, com sistemas lingüísticos fechados e uma concepção de sujeito como fonte e origem de seu dizer.

A $A D$, em seu itinerário histórico, mostra o movimento e as mudanças da teoria do conhecimento, no interior do movimento histórico da sociedade. Nada é definitivamente. Tudo é um continuum e está em relação, no espaço/tempo do acontecimento $^{45}$. De acordo com Possenti (2004, p. 355):

O conhecimento não se produz por acumulação, mas por saltos e mudanças de rumo em relação às etapas anteriores. As novas teorias não são vistas como desenvolvimento e sofisticação das anteriores, mas como efeito, em boa medida, de seu abandono, seja por estarem "esgotadas", seja porque novas problemáticas, novas vontades de verdade tomam seu lugar, tanto teórica quanto politicamente.

Sem a pretensão de esgotar a trajetória da $A D$, primeiro, porque não é esse o objetivo deste trabalho (pesquisadores de renome nacional e internacional já o fizeram muito bem), segundo, porque a história, por ser história não está pronta, nem acabada. O que procuramos pontuar é nosso olhar sobre os saltos, as rupturas, as mudanças e as reconfigurações desse percurso que nos possibilita refletir sobre a $A D$ em suas perspectivas teóricas - hoje, em seu movimento de completude sempre incompleta. Diante disso, vamos apresentar os aspectos relevantes desse

\footnotetext{
${ }^{45}$ Essa afirmação pode ser feita dentro do percurso histórico, deixando claro que a ruptura de que falamos não acontece "num piscar de olhos", mas compreende uma reflexão realizada pelos pesquisadores - em variados momentos e lugares - que marca uma saída processual da base estruturalista para uma perspectiva, que podemos chamar de base enunciativa.
} 
movimento, de sua emergência aos dias atuais, tomando como referência principal os textos de Michel Pêcheux, entre outros ${ }^{46}$.

\subsubsection{Primeira fase da $A D$}

A primeira fase da Análise do Discurso tem como referência o texto Análise Automática do Discurso (AAD-69), que apresenta a proposta teórico-metodológica elaborada por Pêcheux. Na elaboração desta proposta, o autor parte de uma releitura de Saussure. Salienta que, antes da perspectiva saussuriana, a ciência clássica da linguagem, como já referido anteriormente, tinha o objetivo de ser conjuntamente "a ciência da expressão e ciência dos meios desta expressão" (PECHEUX \& FUCHS, 1997, p. 61), sendo que estudar a língua denotava, na maioria das vezes, estudar textos. Esses textos apresentavam dois blocos de questões: aquelas provenientes da prática escolar, correspondentes à compreensão de textos e aquelas provenientes da atividade do gramático sob modalidades normativas e descritivas.

Para Pêcheux e Fuchs (1997, p. 62), a mudança conceptual adotada por Saussure vem separar essa homogeneidade cúmplice entre a prática e a teoria da linguagem. Ao pensar a língua como um sistema, considerando ser ela o único objeto pertinente à ciência lingüística, deixa de reconhecê-la em sua função de exprimir sentido. Com essa mudança, Saussure separa o que é social (a língua) do que é individual (a fala) e, conforme observa Pêcheux, dessa perspectiva, o que funciona é a língua, não podendo o texto ser objeto para a ciência lingüística, ficando de fora a fala como aquela que não se presta ao estudo científico.

Segundo o autor (1997, p. 70), o mestre genebrino apresenta, no Curso de Lingüística Geral, duas maneiras de definição do conceito de língua. Primeiramente, conceitua a língua como a parte social da linguagem que está fora do indivíduo, o qual, em razão disso, não está autorizado a criá-la, nem modificá-la. Em segundo lugar, definindo-a como uma instituição social, estabelece uma dupla oposição: opõe a língua, para Saussure, o mais importante sistema semiológico, ao conjunto dos sistemas semiológicos que apresentam um estatuto científico potencialmente

${ }^{46}$ Outros autores que trataram da trajetória histórica da $A D$ serão utilizados como fonte: Denise Maldidier; Helena H. Nagamine Brandão, Maria da Conceição Fonseca Silva, Fernanda Mussalim e Maria do Rosário Gregolin (as referências vêm sendo acrescentadas no percurso do texto). 
equivalente. A outra oposição vem do termo instituição, que distingue a língua, enquanto instituição social, das outras instituições, tais como os sistemas institucionais jurídico e político. Há aí, segundo Pêcheux, duas exclusões teóricas no que dizem respeito à ciência lingüística: a exclusão da fala e a exclusão das instituições "não-semióticas".

De acordo com Pêcheux (1997, p. 71), essas exclusões feitas por Saussure deixam claras as suas conseqüências:

[...] é um fato que esta oposição autoriza a reaparição triunfal do sujeito falante como subjetividade em ato, unidade ativa de intenções que se realizam pelos meios colocados a sua disposição; em outros termos, tudo se passa como se a lingüística científica (tendo por objeto a língua) liberasse um resíduo, que é o conceito filosófico de sujeito livre, pensado como o avesso indispensável, o correlato necessário do sistema. A fala, enquanto uso da língua, aparece como um caminho da liberdade humana (grifos do autor).

Dentro desse contexto - e por não conceber o sujeito como sujeito livre, fonte do dizer e dono de sua língua em toda atividade lingüística - Pêcheux (1997, p. 74) propõe um deslocamento do objeto com a definição de um nível intermediário entre a língua e a fala, que ele vai chamar de discurso definido em relação com a história e como efeito de sentido produzido entre os seus interlocutores. Sua proposta é que a $A D$ trate desse novo objeto: o discurso que, como observa Gregolin (2004, p. 61), apresenta em sua concepção, o cruzamento de três releituras: Saussure (relido por Pêcheux), Marx (relido por Althusser) e Freud (relido por Lacan), que funde a língua, o sujeito e a história.

Nessa primeira fase da $A D$, com uma metodologia baseada no estruturalismo harrisiano, tem-se a noção de "máquina discursiva", por isso chamada de Análise Automática do Discurso (AAD), por Pêcheux (1997, p. 311), já que em sua proposta teórica

[...] um processo de produção discursiva é concebido como uma máquina autodeterminada e fechada sobre si mesma, de tal modo que um sujeito-estrutura determina os sujeitos como produtores de seus discursos: os sujeitos acreditam que "utilizam" seus discursos quando na verdade são seus "servos" assujeitados, seus "suportes". 
Como é possível depreender dessa afirmação, o sujeito do discurso é definido a partir do conceito de sujeito-estrutura entendido como lugar determinado na estrutura social e de sujeito-assujeitado como suporte para a produção desse discurso. O sujeito acredita ser o produtor de seu discurso, mas não o é, ele é assujeitado ao lugar a que pertence na estrutura social, pois está sujeito às regras próprias do discurso que enuncia.

A contestação que Pêcheux faz à noção saussureana de sujeito livre é reforçada pela noção de condições de produção ${ }^{47}$ do discurso, a partir do questionamento que faz ao esquema das funções da linguagem de Jakobson, argumentando que a teoria da informação subjacente a esse esquema nos permite falar de mensagem como transmissão de informação e que ele propõe, como já citado anteriormente, o termo discurso que não se constitui em uma transmissão de informação, mas, de modo geral, de um "efeito de sentidos" entre os interlocutores (PÊCHEUX, 1997, p. 81-82).

Entretanto, a concepção de língua de Pêcheux, na AAD-69 é ainda uma concepção considerada pobre, já que "é fortemente marcada pela ideologia estrutural: o "fundo invariante" versus a seleção/combinação, isto é, a sintaxe versus o léxico" (MALDIDIER, 2003, p. 24). A exploração metodológica que marca esta primeira fase da AD (AAD69) é a noção de "maquinaria-discursiva-estrutural" que para Pêcheux (1997, p. 312), presumia dois gestos consecutivos:

[...] a) reunir um conjunto de traços discursivos empíricos ("corpus de seqüências discursivas") fazendo a hipótese de que a produção desses traços foi, efetivamente, dominada por uma, e apenas uma, máquina discursiva (por exemplo um mito, uma ideologia, uma episteme). b) construir, a partir desse conjunto de traços e através de procedimentos lingüisticamente regulados, o espaço da distribuição combinatória das variações empíricas desses traços: a construção efetiva desse espaço constitui um gesto epistemológico de "ascensão" em direção à estrutura desta máquina discursiva que supostamente as engendrou.

É possível afirmar, portanto, que a AD1 (AAD69) parte de um corpus de seqüências discursivas fechadas sobre si mesmas, escolhidas em um contexto discursivo supostamente dominado por condições de produção estáveis e

${ }^{47}$ A questão das condições de produção será tratada no próximo capítulo. 
homogêneas. No entanto, ao mesmo tempo em que o quadro teórico conferia realidade à nova disciplina, evidenciava seus limites e bloqueios. Os deslocamentos que ela postula não são recebidos sem crítica por parte dos próprios analistas do discurso, dos lingüistas e dos pesquisadores de outros campos do conhecimento.

O reconhecimento dos limites e bloqueios que o quadro teórico da AD1 apresenta e as críticas recebidas é que irão possibilitar a reflexão e as reconfigurações desse quadro como mostra a segunda fase da AD.

\subsubsection{Segunda fase da $A D$}

A segunda fase da $A D$ (AD2), que tem seu início mais ou menos depois de 1975, vai partir da sua construção inicial e, principalmente, das críticas pertinentes que sofreu. Neste momento, a noção de máquina estrutural fechada começa a explodir, dando lugar a reconfigurações ${ }^{48}$ provocadas pelas transformações da conjuntura teórica e política que acontece na França ${ }^{49}$.

Dentre as reconfigurações com que Pêcheux sinaliza nesta fase, uma se tornou relevante nas reflexões que se fizeram/fazem em torno do desenvolvimento da AD: o conceito de formação discursiva que ele toma de empréstimo de Foucault, em uma re-interpretação que se torna o dispositivo desencadeador do processo de transformação na concepção do objeto de análise da Análise do Discurso.

Foucault (1995, p.136) conceitua formação discursiva (FD) como:

[...] um conjunto de regras anônimas, históricas, sempre determinadas no tempo e no espaço, que definiram, em uma dada época e para uma determinada área social, econômica, geográfica ou lingüística, as condições de exercício da função enunciativa.

\footnotetext{
48 "Efetivamente, toda a história da AD francesa é, grosso modo, depois da segunda metade da década de 1970, a história das desconstruções-reconfigurações a partir da sua construção inicial". MALDIDIER, D. op.cit., 1997, p. 24

${ }^{49} \mathrm{~A}$ conjuntura teórica que diz respeito à lingüística, mostra o surgimento de novas abordagens com a pragmática, a filosofia da linguagem, a análise da conversação, as quais refletem a crise das lingüísticas formais e o sucesso da lingüística da enunciação. É a recepção de Bakhtin-Volochinov. A agitação proveniente dessa reviravolta teórica traz consigo referências novas, a produção de novos temas de pesquisa. MALDIDIER, op. cit., 1997, p.25.
} 
Isso quer dizer que, no processo discursivo, uma FD define aquilo que pode/deve ser dito, não pode/não deve ser dito pelo sujeito, a partir de um determinado lugar social.

Dessa perspectiva, Brandão (2002: 07) observa que Pêcheux, em sua autocrítica sobre a AAD69,

[...] reformula sua noção de FD ao reconhecer que uma FD não é um espaço estrutural fechado, pois está em relação paradoxal com seu "exterior" ao ser constitutivamente "invadida por elementos que vêm de outro lugar (isto é, de outras FDs) que se repetem nela, sob a forma de pré-construído e de discursos transversos". Surge então a noção de interdiscursividade para designar o "exterior específico" que irrompe no interior de uma FD.

É abandonada, neste momento, a idéia de homogeneidade enunciativa, pois a emergência da noção de formação discursiva coloca em cheque a idéia de máquina estrutural fechada, já que essa FD será sempre invadida por elementos que vêm de outro lugar, ou seja, de outras formações discursivas, tendo, portanto, seu espaço atravessado pelo "pré-construído" 50 , - discursos que vieram de uma construção anterior e exterior - que são por essa FD considerados, sempre em uma relação de confronto ou de aliança. Dessa maneira, como observa Brandão (1994, p. 39), uma formação discursiva se constitui como um sistema de paráfrase, ou seja, é um espaço em que enunciados são retomados e reformulados num empenho incessante de fechar suas fronteiras em busca da preservação de sua identidade.

A noção de formação discursiva introduzida por Foucault é re-trabalhada por Pêcheux por meio de sua inscrição no quadro do materialismo althusseriano. Enquanto aquele caracteriza-a, ao mesmo tempo, como dispersão, raridade, unidade dividida e sistema de regras, fundamentado em uma concepção que deixa em aberto a textualização final (CHARAUDEAU, 2004, p. 241), Pêcheux (1971, p.8-

\footnotetext{
${ }^{50}$ A noção de pré-construído - elaborada inicialmente por Henry e desenvolvida posteriormente por Pêcheux - consiste em uma reformulação das teorias de Ducrot sobre a pressuposição.O préconstruído pode ser entendido como a marca, no enunciado, de um discurso anterior; dessa maneira, ele se opõe ao que é construído no momento da enunciação. Um sentimento de evidência se associa ao pré-construído, em razão de ser ele um "já dito" e porque esquecemos quem foi seu enunciador. CHARAUDEAU, P \& MAINGUENEAU, D. Dicionário de Análise do Discurso. Coordenação da tradução Fabiana Komesu. São Paulo-SP: Contexto, 2004, p. 401.
} 
9) vai introduzir o conceito de formação ideológica como um elemento capaz de interferir

[...] como uma força que se confronta com outras forças, na conjuntura ideológica característica de uma formação social, em um dado momento; cada formação ideológica constitui assim um conjunto complexo de atitudes e de representações que não são nem "individuais" nem "universais", mas se reportam mais ou menos diretamente às posições de classe em conflito, umas em relação a outras. (...) as formações ideológicas assim definidas comportam necessariamente, como um de seus componentes uma ou várias formações discursivas interligadas que determinam aquilo que pode e deve ser dito (articulado sobre a forma de uma conferência, de um sermão, de um panfleto, de uma exposição, de um programa, etc.) a partir de uma dada posição em uma dada conjuntura (...) as palavras mudam de sentido segundo as posições mantidas por aqueles que as empregam, ou pode-se determinar agora: as palavras "mudam de sentido" ao passar de uma formação discursiva para outra.

Consideradas dessa forma, a formação ideológica $(F I)$ e a formação discursiva (FD) vão levar ao seguinte postulado defendido pelo autor (1997, p. 314)

[...] as relações entre as 'máquinas' discursivas estruturais se constituem em relações de forças desiguais entre processos discursivos, estruturando o conjunto de 'dispositivos' com influência desigual uns sobre os outros: a noção de formação discursiva, tomada de empréstimo a Michel Foucault, começa a fazer explodir a noção de máquina estrutural fechada na medida em que o dispositivo da FD está em relação paradoxal com seu 'exterior'.

A noção de 'interdiscurso' nasce nesse momento, para destacar o 'exterior específico' que surge no interior de uma FD. Entretanto, ao conceber a relação de entrelaçamento desigual da FD com um exterior, Pêcheux (1997: 314) tem de admitir

[...] os pontos polêmicos que se travam nas fronteiras internas da FD, as zonas atravessadas por toda uma série de efeitos discursivos, tematizados como efeitos de ambigüidade ideológica, de divisão, de resposta pronta e de réplica 'estratégicas'.

Segundo Gregolin (2004, p. 62), esse é um período em que as propostas pecheutianas enfrentam polêmicas, passam por reajustes e reconfigurações 
importantes para o desenvolvimento da $\mathrm{AD}$, que são visíveis, por exemplo, no artigo A Propósito da Análise Automática do Discurso: atualização e perspectivas, escrito por Pêcheux e Fuchs, em 1975. Nesse artigo, os autores (1975, p. 163-164) apresentam o "quadro epistemológico geral" da $A D$, em que articulam três áreas do conhecimento científico, deixando claro o vínculo estabelecido com Saussure, Marx e Freud:

1. o materialismo histórico, como teoria das formações sociais e de suas transformações e da ideologia;

2. a lingüística, como teoria dos mecanismos sintáticos e dos processos de enunciação ao mesmo tempo;

3. a teoria do discurso, como teoria da determinação histórica dos processos semânticos.

Nesse mesmo artigo, Pêcheux vai retrabalhar a inter-relação entre língua, discurso, ideologia e sujeito ${ }^{51}$, formulando sua teoria dos 'dois esquecimentos': defendendo que o sujeito do discurso é determinado pelos esquecimentos que 0 constituem.

No esquecimento $n^{\circ} 1$, o sujeito tem a ilusão de que é a fonte absoluta do seu dizer, a origem do sentido do seu discurso, apagando, inconscientemente, toda e qualquer informação que remeta ao exterior de sua formação discursiva.

O esquecimento $n^{\circ} 2$ se caracteriza por um funcionamento do tipo préconsciente/consciente, apresentando-se como ponto de articulação entre os aspectos lingüísticos e a teoria do discurso. Lançando mão de estratégias discursivas para formular mais adequadamente o que pensa, o sujeito tem ilusão da transparência de sentido, de que o discurso reflete o conhecimento objetivo que tem da realidade. Acreditando que sabe e controla tudo o que diz, esquece que 0 discurso caracteriza-se pela retomada do "já dito".

Em Semântica e Discurso - uma crítica à afirmação do óbvio (1997a, p. 9092), Pêcheux vai propor mudanças teóricas e rever conceitos apresentados na primeira fase. Considerando a um só tempo dois elementos - os fenômenos lingüísticos e os lugares de questões filosóficas - como próprios da região de

${ }^{51}$ O refinamento desses quatro aspectos se encontra, de forma detalhada, no artigo acima mencionado, às páginas 163 a 198, bem como uma reflexão sobre outros aspectos, também muito importantes, como condições de produção e análise lingüística. 
articulação da Lingüística com a teoria dos processos ideológicos e científicos, que, por sua vez, é parte da ciência das formações sociais, o autor propõe uma teoria materialista do discurso. Postula que o sistema da língua é "o mesmo para o materialista e para o idealista, para o revolucionário e para o reacionário, para aquele que dispõe de um conhecimento dado e para aquele que não dispõe desse conhecimento", entretanto, não se pode concluir que seja o mesmo discurso.

Da mesma maneira que os processos ideológicos simulam os processos científicos, a língua é a base lingüística comum de discursos diferenciados, ou seja, o sistema lingüístico (enquanto conjunto de estruturas fonológicas, morfológicas e sintáticas), que se caracteriza como o objeto da Lingüística, é a materialidade lingüística na qual se desenvolvem os processos discursivos. Conforme Silva (2003, p. 112), o sentido está no plano do discurso que é diferente do plano lingüístico como sua base material que, do ponto de vista da $A D$, é opaca e não-transparente.

A partir dessa perspectiva, o autor revê a questão dos "dois esquecimentos" e, conseqüentemente, a constituição do sentido, já que, para o autor, a constituição do sujeito está vinculada à do sentido. No que diz respeito aos "esquecimentos" formulados anteriormente, Pêcheux (1997a, p. 174-175). argumenta que os mesmos "são insuficientes, na medida em que levam a fazer do pré-consciente uma zona autônoma com relação ao inconsciente, delimitado pela barreira do recalque e da censura"

Diante disso, retoma a questão do pré-consciente, através da reelaboração feita por Lacan, fundamentando-se aí para afirmar que o que ele continuará a chamar de "esquecimento № 2" cobre exatamente o funcionamento do sujeito do discurso na formação discursiva que o domina, e que é aí, precisamente, que se apóia sua "liberdade" de sujeito-falante (p.175). Vai postular mais adiante que $o$ efeito da forma-sujeito ${ }^{52}$ do discurso é, pois, sobretudo, o de mascarar objeto daquilo que chamamos o "esquecimento $n^{\circ} 1$ ", pelo viés do funcionamento do "esquecimento $n^{\circ}$ 2" (p.177). Vemos, portanto, que o sujeito tem uma aparente "liberdade" para assumir uma posição que, na verdade, é o efeito da formação ideológica e da formação discursiva exteriores a esse sujeito.

${ }^{52} \mathrm{O}$ autor esclarece em nota que a forma-sujeito é a forma de existência histórica de qualquer indivíduo, agente das práticas sociais. Conf. nota em PÊCHEUX, op cit.: $1997^{\mathrm{a}}$, p.183. 
Essa questão do sujeito está, como referido anteriormente, relacionada à questão do sentido. Pêcheux afirma que a materialidade do sentido consiste na dependência constitutiva do "todo complexo das formações ideológicas" (p.160), defendendo assim a não transparência da linguagem. $O$ autor explica essa dependência por meio de duas teses ${ }^{53}$.

A primeira explicita que a formação discursiva é o espaço de construção do sentido e pode ser assim resumida: as palavras, expressões, proposições, etc., mudam de sentido segundo as posições sustentadas por aqueles que as empregam, ou seja, adquirindo-os em referência às formações ideológicas nas quais essas posições se inscrevem.

A segunda postula que toda formação discursiva dissimula, pela transparência do sentido que nela se constitui, sua dependência em relação ao "todo complexo com dominante" ${ }^{154}$ das formações discursivas, como parte do complexo das formações ideológicas.

Numa evidência de sua vinculação às propostas althusserianas, Pêcheux trata da interpelação ideológica, argumentando que o sujeito se constitui pelo "esquecimento" daquilo que o determina e pela interpelação do indivíduo em sujeito de seu discurso, que se realiza pela identificação (do sujeito) com a formação discursiva que o constitui. A noção de sujeito, na AD1 assujeitado, vai sendo repensada por essa preocupação nova (o exterior como constitutivo do interior), e possibilita o questionamento da concepção original da FD e o reconhecimento do discurso como objeto heterogêneo.

Apesar dessa reflexão, para Pêcheux, no que diz respeito aos procedimentos de análise, a AD2 apresenta muito poucas inovações, avançando efetivamente em relação ao objeto de análise: discursos menos "estabilizados" por serem produzidos a partir de condições de produção menos homogêneas.

\footnotetext{
${ }^{53}$ Só citaremos que são duas teses, sem entrarmos em uma discussão sobre o assunto, pois não é este o propósito deste trabalho. As considerações detalhadas o leitor encontra em : PÊCHEUX, M. Semântica e Discurso - uma crítica à afirmação do óbvio. Trad. de Eni P. Orlandi [et al.]. 3. ed. Campinas-SP: Editora da UNICAMP, 1997a e SILVA, Ma da Conceição F. Os discursos do cuidado de si e da sexualidade em Claudia, Nova e Payboy. Campinas-SP: UNICAMP, 2003 (Tese de Doutoramento).

${ }^{54}$ Pêcheux chama o "todo complexo com dominante" das formações discursivas de interdiscurso que também está submetido à lei de desigualdade que caracteriza o complexo das formações ideológicas. Conf. p. 162.
} 


\subsubsection{Terceira fase da $A D$}

$\mathrm{Na}$ terceira fase que, mais ou menos, pode ser temporalmente marcada como o período que compreende os anos de 1980 a 1983, as reflexões continuam, dando lugar a novas reconfigurações. Inicialmente, alguns pontos de referência (PÊCHEUX, 1983, p. 315-6), são destacados na mudança do quadro epistemológico desta fase:

1. a acentuação do primado teórico do outro sobre o mesmo, que vai resultar na desconstrução da maquinaria discursiva estrutural fechada;

2. a explosão definitiva do procedimento da $A D$ por etapas, com ordem fixa, em razão da desestabilização das garantias sócio-históricas que presumiam assegurar a priori a pertinência teórica e os procedimentos de uma construção empírica do corpus;

3. o estudo da construção dos objetos discursivos e dos acontecimentos, bem como dos "pontos de vista" e "lugares enunciativos no fio intradiscursivo", oportunizado pelo desenvolvimento de muitas pesquisas sobre os encadeamentos "interfrásticos";

4. a tematização das formas lingüístico-discursivas do discurso-outro, fundamentada nos aspectos teóricos já desenvolvidos sobre a heterogeneidade enunciativa, como: o "discurso de um outro, colocado em cena pelo sujeito, ou o discurso do sujeito se colocando em cena como um outro (as diversas formas da 'heterogeneidade mostrada') [...] e a insistência de um 'além' interdiscurso que vem, aquém do todo autocontrole funcional do 'ego-eu', enunciador estratégico que coloca em cena 'sua' seqüência".

Além desses aspectos, a obra de Bakhtin (Voloshinov), Marxismo e Filosofia da Linguagem, publicada em 1929 e traduzida na França em 1977, passou a fazer parte das discussões dos lingüistas marxistas que destacavam a importância de suas idéias se faz sentir na $A D$, pela dimensão sócio-interacionista da sua concepção de linguagem. Essa concepção defende o princípio de que toda palavra é dialógica por natureza, porque pressupõe sempre o outro. Outro que, "na concepção bakhtiniana, é ainda o outro discurso ou os outros discursos que atravessam toda fala numa relação interdiscursiva" (BRANDÃO, 2002, p. 8). 
A recepção das idéias do teórico russo não foi unanimidade entre os estudiosos franceses. Pêcheux e seu grupo, por exemplo, não aceitaram as idéias de Bakhtin, argumentando que este não podia ser referência teórica para eles pela proximidade que tinha com a psicologia social de Plekhanov (SILVA, 2003, p. 1167).

Em Só há causa daquilo que falha ou o inverno político francês: início de uma retificação, o pesquisador francês reconhece como problemática a Tríplice Aliança teórica que se configurou em torno dos nomes de Saussure, Lacan e Althusser, na década de 60, na França. Pêcheux faz um retorno às teses foucaultianas, e começa a desenhar uma nova configuração no quadro teórico da AD. De acordo com Silva (2003, p. 117), refletindo sobre a categoria marxista da contradição, ele desloca as noções de "formas de repartição" e de "sistemas de dispersão" para colocar em funcionamento as noções de "identidade e divisão do sentido do enunciado" e de formação discursiva dividida que se estabelece na contradição, etc., apresentando uma nova maneira de pensar essa contradição: a heterogeneidade.

Muito embora as chamadas "três épocas da $A D$ " tenham se constituído de construção, desconstruções e reconfigurações que resultaram em aprofundamentos teóricos importantes, ainda ficaram, como diz Pêcheux, muitos questionamentos. Esses questionamentos e outros que foram surgindo, evidenciam uma disciplina aberta a outras reflexões e reformulações, que foi se expandindo para outras disciplinas/áreas do conhecimento. Afinal, ela já nasceu interdisciplinar.

\subsubsection{A AD e o sujeito}

A noção de subjetividade está presente nas reflexões teóricas da $A D$ desde a sua emergência ${ }^{55}$, não estando incólume às reformulações pelas quais a disciplina passou em sua trajetória. Presente em todo o percurso dessa disciplina como uma questão fundante, sempre relacionada ao discurso e ao sentido, a concepção de sujeito, inicialmente assujeitado e/ou tendo a polaridade centrada no eu ou no $t u$, apresenta um processo de reconfigurações que vai postulá-la em uma relação entre

${ }^{55}$ A noção de subjetividade foi levantada muito antes do nascimento da $A D$, pela filosofia, que sempre se preocupou e refletiu sobre o assunto. Neste trabalho, entretanto, limitamo-nos às reflexões sobre a subjetividade no campo específico da AD. 
identidade/alteridade, ou seja, a relação não é mais centrada nem no eu, nem no $t u$, mas no espaço discursivo criado entre ambos.

Na AAD-69, Pêcheux apresenta a noção de um sujeito assujeitado a uma "maquinaria discursiva estrutural", tendo em vista que está subordinado às normas específicas que circunscrevem o discurso que enuncia. Dessa perspectiva, "quem de fato fala é uma instituição, ou uma teoria, ou uma ideologia" (MUSSALIM, 2001, p.133). Como já citado anteriormente, o autor defende - em um contraponto à noção de sujeito de uma filosofia idealista e à evidência do sentido - que o sujeito não é dado a priori, mas é constituído no discurso.

Fundamentado na tese althusseriana de que "a ideologia interpela os indivíduos em sujeitos", Pêcheux postula uma noção de sujeito delimitada pelo lugar e pela posição de onde fala e este sujeito fala do interior de uma formação discursiva regulada por uma formação ideológica. O sujeito acredita que o discurso é seu, mas, na verdade, é seu 'servo' assujeitado, seu 'suporte', já que é a formação discursiva que define "o que pode e deve ser dito pelo sujeito".

$\mathrm{Na}$ AD-2, temos, como já referido, a re-significação da definição da FD de dispositivo estrutural fechado para uma noção de FD (tomada de empréstimo a Michel Foucault) que se coloca em relação com o seu "exterior", já que é invadida por elementos que vêm de outras FDs, que nela se repetem, "fornecendo-Ihe suas evidências discursivas fundamentais ( por exemplo sob a forma de "pré-construídos" e de "discursos transversos") (PÊCHEUX, 1997, p. 314). Estabelece-se, dessa forma, a noção de interdiscurso e o sujeito deixa de ser marcado pela idéia de unidade da $A D-1$, para ser concebido como aquele que realiza diferentes papéis conforme as várias posições que ocupa no espaço interdiscursivo.

O sujeito, no entanto, mesmo tendo a possibilidade de exercer vários papéis, continua sendo visto, nessa fase, como assujeitado ao dispositivo da FD com o qual ele se identifica. Este é um sujeito que opera nos níveis do esquecimento o 1 e do esquecimento no 2 . Pêcheux introduz aqui, conforme observa Brandão (1998, p. 41),

"o 'tema espinosista da ilusão subjetiva'. Para um sujeito que se desdobra em vários papéis segundo as várias posições que ocupa numa FD (que é atravessada por várias FDs) a ilusão discursiva da unidade, da origem, constitui uma 'ilusão necessária' para a manutenção da identidade." 
Segundo a autora, essa identidade tem seu fechamento colocado em causa pelo reconhecimento da alteridade que surge no interior de um sujeito que se distingue pela dispersão das diferentes posições que assume em seu discurso. Começa, então, a se delinear uma fase que evidencia uma preocupação nova, que vinha sendo engendrada há tempo: a heterogeneidade discursiva que leva Pêcheux a repensar a própria concepção de formação discursiva.

$\mathrm{Na}$ AD-3, dentre as reconfigurações que se presentificam, a noção de sujeito sofre um novo deslocamento, já que sai do assujeitamento da maquinaria discursiva estrutural fechada, para "máquinas discursivas paradoxais". O primado teórico do outro sobre o mesmo é o que vai orientar a questão da alteridade na identidade discursiva. Pêcheux vai ressaltar a produção de pesquisas sobre encaminhamentos intradiscursivos que possibilitam à AD-3 o estudo da temática das formas lingüísticodiscursivas do discurso - outro (BRANDÃO, 1998, p. 42).

Esses deslocamentos vão se ampliar com os estudos de Authier-Revuz, como veremos no capítulo seguinte. 
A maior riqueza do homem é a sua incompletude. Nesse ponto sou abastado. Palavras que me aceitam como sou - eu não aceito.

Não agüento ser apenas um sujeito que abre portas, que puxa válvulas, que olha o relógio, que compra pão às 6 horas da tarde, que vai lá fora, que aponta o lápis, que vê a uva etc, ec. Perdoai.

Mas eu preciso ser Outros. Eu penso renovar o homem usando borboletas. (Manoel de Barros, Retrato do Artista quando Coisa, 2001, p.79) 


\section{CAPÍTULO III}

\section{NEM MAQUINARIA, NEM ASSUJEITAMENTO INTERAÇÃO E INTERDISCURSIVIDADE.}

A $A D$, inicialmente constituída com a finalidade de refletir/interpretar 0 discurso político, no movimento marcado pelas suas reconfigurações, atinge hoje os discursos do cotidiano em suas diferentes modalidades. As práticas lingüísticas, nos mais variados contextos, podem ser e são estudadas na perspectiva discursiva. Hoje, a AD intensifica sua prática e vem sendo influenciada por outras tendências que abordam a linguagem em uso como a pragmática e a lingüística textual. Essa influência é vista com bons olhos por analistas como Brandão (2002, p. 10), que defende como

[...] compreensível na própria agenda programática da $A D$, na medida em que operando com conceitos como heterogeneidade, alteridade, o outro no mesmo, ela não pode se furtar ao diálogo interdisciplinar sem perder, entretanto, o rosto, a identidade, pois uma disciplina que preza a historicidade, não pode se deixar congelar por qualquer tipo de imobilismo ou fixidez.

$E$ a $A D$ não se deixou e nem se deixa imobilizar. Vale ressaltar que, como observa Mutti (2004, p. 2): o próprio Pêcheux deixou uma obra marcada pela constante reflexão de suas posições teóricas, evidenciando que a Análise do Discurso se constitui por re-significações teóricas, em um processo de construção, desconstrução e reconstrução que não se deu por pronto. Partindo dessa característica, é possível afirma que a AD hoje é uma disciplina de base enunciativa, tendo em vista sua trajetória teórica de um continuum inter-relacionamento com disciplinas de outras áreas.

Com a finalidade de situar esta $A D$ no contexto brasileiro, recorremos a dois autores que, em suas produções fazem menção aos analistas do discurso em nosso país. Robert de Beaugrande (2005, p. 4), em seu artigo $A$ análise do discurso no Brasil do 'mercado livre', argumenta que, no caso do Brasil, a Análise do Discurso recebeu um 
grande impulso da Educação Libertadora da obra do educador Paulo Freire. Em seu trabalho com alfabetização de adultos, foi o primeiro pesquisador a reconhecer a necessidade de elaborar um projeto de ensino que contemplasse uma interação continua e dialética entre a teoria e a prática. Freire enfrentou o desafio de trabalhar nessa perspectiva teórica e construiu uma teoria praticável.

Possenti (2004, p. 354), em seu artigo Teoria do Discurso: um caso de múltiplas rupturas ressalta, em nota, que a produção brasileira em $A D$ é significativa e destaca os principais pesquisadores responsáveis por essa produção no país. Tratando de diferentes temáticas em $A D$, estão Helena $H$. Nagamine Brandão (1991), Eni P. Orlandi (1999), João Wanderley Geraldi (1991), Maria IIma HadlerCondry (1988) e Carlos Alberto Faraco (2003). À lista acrescentamos as produções de Sírio Possenti (2002) e Maria do Rosário Gregolin (2004) ${ }^{56}$. A estes nomes, que são pioneiros no desenvolvimento de pesquisas em $A D$, outros pesquisadores, em todo o país, tornam a lista bem mais extensa, confirmando a produção significativa em $A D$ a que se refere Possenti.

Como observa Brandão (2002, p. 9), é possível perceber na trajetória da Análise do Discurso,

[...] houve um profundo deslocamento teórico e metodológico em relação ao objeto discurso: de uma concepção de discurso circunscrita à noção estrutural, homogeneizante de uma FD, (...) passa-se para uma concepção de linguagem enquanto diálogo e de discurso enquanto espaço de heterogeneidade, de interação intersubjetiva e interdiscursiva, de negociação, confronto, polêmica entre o um e o outro.

A Análise do Discurso oportuniza, portanto, uma discussão que trata o texto como um todo e, diferentemente de uma postura abstrata e fragmentada, possibilita uma reflexão sobre enunciados concretos construídos por sujeitos ideologicamente constituídos, pois é através do uso da língua dentro do contexto social em que vive e atua que o homem se constitui e estabelece vínculos sociais com outros sujeitos e outras culturas.

\footnotetext{
${ }^{56}$ Todos os pesquisadores têm várias obras além das citadas entre parênteses e referenciadas no final desta tese.
} 
Nessa perspectiva teórico-discursiva, em que se explicitam o caráter histórico e social da linguagem, conceitos fundantes da $A D$ são retomados e reformulados.

\subsection{O SUJEITO E AD HOJE}

Os trabalhos de Authier-Revuz em relação à noção de sujeito são relevantes para a $A D$, em sua vertente mais atual. Essas pesquisas apontam um sujeito dividido, clivado entre o consciente e o inconsciente, deixando o inconsciente de ser o centro deste sujeito. O sujeito perde a sua centralidade, tendo em vista que o "outro" faz parte de sua identidade. É, portanto, um sujeito descentrado e constitutivamente heterogêneo, como o discurso também o é. Segundo Brandão (1998, p. 43),

[...] a descoberta do inconsciente por Freud teria provocado conseqüências semelhantes às das 'feridas narcísicas' inflingidas ao homem por duas outras grandes descobertas anteriores: a de Copérnico [...] e a de Darwin [...]. Com a descoberta freudiana, o eu perde a sua centralidade, não sendo mais "senhor de sua morada".

Em uma vertente bem atual da AD, temos a noção de sujeito construída a partir as idéias de Bakhtin. Para ele a língua é vista a partir de uma concepção de linguagem, onde o exterior, o outro são determinantes. Coloca a interação verbal como a chave da realidade fundamental da língua que se realiza na e pela enunciação (produto da interação de dois indivíduos socialmente organizados e que se dá na interação verbal: locutor/interlocutor). Defende o conceito de dialogismo e valor duplo da palavra, ou seja, no seu sentido de unidade lexical e no sentido de encadeamento de idéias, entendida como unidade de enunciação.

Nessa perspectiva, a linguagem é uma atividade constitutiva e sempre dialógica. É um modo de ação social fundamental no desenvolvimento de todo e qualquer homem e a condição indispensável de apreensão de conceitos que permitem aos sujeitos compreenderem o mundo e nele agir. É ainda lugar de conflito, de encontros, de desencontros e de confrontos de posições, porque é através da linguagem que essas posições se tornam públicas. (Cf. GERALDI, 1991, 
p. 4): “Estudar a linguagem é abarcá-la nessa complexidade, é apreender o seu funcionamento que envolve não só mecanismos lingüísticos, mas também ‘extralingüísticos'”(BRANDÃO, 1994, p. 91).

Nesse sentido, o sujeito se constitui na e pela linguagem; sujeito heterogêneo que deixa de ser visto como único na instância discursiva, para deixar evidente seu caráter contraditório: marcado pela incompletude, deseja "ser inteiro", aproximando-se do outro, também incompletude por definição, na busca da totalidade nunca alcançada. Assim, numa relação dinâmica entre identidade e alteridade, o sujeito é ele mais a complementação do Outro.

O texto encena essa relação, pois nele o sujeito divide seu espaço com o outro, já que nenhum discurso provém de um sujeito como fonte única de seu dizer. Como observa Brandão (2002, p. 8):

o conceito de subjetividade se desloca para um sujeito que se cinde porque átomo, partícula de um corpo histórico-social no qual interage com outros discursos de que se apossa ou diante dos quais se posiciona (ou é posicionado) para construir sua fala.

\subsection{A AD e as condições de produção do discurso}

As últimas décadas têm se voltado para uma Lingüística da Enunciação que, como já mencionamos, pressupõe o desenvolvimento dos estudos da linguagem a partir da análise do todo do texto, voltada para a linguagem em uso. Esses avanços lingüísticos fundamentam-se, entre outros aspectos, em uma revisão/reconfiguração dos conceitos e das categorias existentes e na criação de outros que compõem o todo da teoria.

Nessa perspectiva da Lingüística da Enunciação, os falantes não produzem frases isoladas, mas produzem discursos que envolvem circunstâncias enunciativas que se referem, tanto ao contexto imediato, como ao contexto sócio-histórico e ideológico em que tais discursos são produzidos. Diante disso, é possível afirmarmos que as escolhas feitas pelos sujeitos, para dizer o que dizem, não são aleatórias e compreendem o que os pesquisadores chamam de condições de produção (doravante CP) do discurso. 
Precisar claramente a noção de CP não é tarefa simples e, em razão disto, vários pesquisadores trataram e vêm tratando do assunto, dentre eles, vamos explicitar o pensamento dos franceses M. Pêcheux e J.J. Courtine e dos brasileiros Hakira Osakabe, Eni P. Orlandi e Silvia Helena B. Cardoso.

\subsubsection{CP - as 'formações imaginárias'}

A definição empírica da noção de CP foi proposta inicialmente por Michel Pêcheux através de uma esquematização "[...] de formações imaginárias que designam o lugar que $A$ e $B$ se atribuem cada um a si e ao outro, a imagem que eles se fazem de seu próprio lugar e do lugar do outro" (PÊCHEUX,1997, p. 82-4). Apresentando os elementos estruturais pertencentes às CPs em duas famílias de esquema: o esquema reacional proveniente das teorias psicofisiológicas e psicológicas do comportamento e o esquema informacional oriundo das teorias sociológicas e psicossociológicas da comunicação, o autor escolhe o segundo, pelo fato de ser este o esquema que apresenta "... a vantagem de pôr em cena os protagonistas do discurso bem como seu "referente" ${ }^{157}$.

O esquema assim se apresenta:

$\frac{(£)}{\mathrm{D}}$
$\mathrm{R}$
E compreende respectivamente:
A: o destinador
B: o destinatário
R: o referente
$(£)$ : o código lingüístico comum a A e a B
$\rightarrow:$ o contato estabelecido entre A e B
D: a seqüência verbal emitida por A em direção a B

${ }^{57}$ Toda a questão teórica das condições de produção e o quadro do jogo de imagens propostos por Pêcheux estão In: GADET, F. \& HAK, T.(Orgs.). Por uma análise automática do discurso - uma introdução à obra de Michel Pêcheux. 3aㅡ edição, Campinas-SP: Editora da UNICAMP, 1997, p 77-87. 
No que se refere à seqüência verbal emitida por $A$ em direção a $B$, Pêcheux faz a substituição do termo mensagem (como transmissão de informação) pelo termo discurso, por defender que não se trata fundamentalmente de uma transmissão de informação, mas de um "efeito de sentidos" entre A e B. (grifos do autor).

É importante ressaltar que para o autor os elementos $A$ e $B$ não caracterizam a "presença física de organismos humanos individuais", mas que estes designam "lugares determinados na estrutura de uma formação social, lugares dos quais a sociologia pode descrever o feixe de traços característicos". Assim, em um contexto de produção econômica empresarial, o "lugar' do patrão, o "lugar" do empregado e o "lugar" do gerente, por exemplo, vêm marcados por "propriedades diferenciais determináveis".

Pêcheux (1997:82) levanta a hipótese de que esses lugares estão representados nos processos discursivos, mas descarta que o lugar como feixe de traços característicos desempenhe sua função como tal no interior destes processos. Acredita que ele está aí representado, mas transformado, ou seja, "o que funciona nos processos discursivos é uma série de formações imaginárias que designam o lugar que A e B se atribuem cada um a si e ao outro, a imagem que eles se fazem se seu próprio lugar e do lugar do outro" (grifos do autor).

O autor, considerando que todo processo discursivo admite a presença dessas formações imaginárias e a importância da imagem que se fazem os interlocutores nesses processos, representou-as através do quadro abaixo, onde faz um levantamento das questões que evidenciariam o que ele chama de jogo de imagens de um discurso. 


\begin{tabular}{|c|c|c|c|}
\hline \multicolumn{2}{|c|}{$\begin{array}{l}\text { Expressão que designa as } \\
\text { formações imaginárias }\end{array}$} & $\begin{array}{l}\text { Significação da } \\
\text { expressão }\end{array}$ & $\begin{array}{l}\text { Questão implícita cuja } \\
\text { "resposta" subentende a } \\
\text { formação imaginária } \\
\text { correspondente }\end{array}$ \\
\hline \multicolumn{2}{|r|}{$\mathrm{I}_{A}(\mathrm{~A})$} & $\begin{array}{l}\text { Imagem do lugar de } \\
\text { A para o sujeito } \\
\text { colocado em A }\end{array}$ & $\begin{array}{l}\text { "Quem sou eu para lhe } \\
\text { falar assim?" }\end{array}$ \\
\hline & $\mathrm{I}_{\mathrm{A}}(\mathrm{B})$ & $\begin{array}{l}\text { Imagem do lugar de } \\
\text { B para o sujeito } \\
\text { colocado em A }\end{array}$ & $\begin{array}{l}\text { "Quem é ele para que eu } \\
\text { Ihe fale assim?" }\end{array}$ \\
\hline \multirow{2}{*}{\multicolumn{2}{|c|}{$I_{B}($}} & $\begin{array}{l}\text { Imagem do lugar de } \\
\text { B para o sujeito } \\
\text { colocado em B }\end{array}$ & $\begin{array}{l}\text { "Quem sou eu para que } \\
\text { ele me fale assim?" }\end{array}$ \\
\hline & & $\begin{array}{l}\text { Imagem do lugar de } \\
\text { A para o sujeito } \\
\text { colocado em B }\end{array}$ & $\begin{array}{l}\text { "Quem é ele para que me } \\
\text { fale assim?" }\end{array}$ \\
\hline A & $I_{A}(R)$ & $\begin{array}{l}\text { "Ponto de vista" de } \\
\text { A sobre R }\end{array}$ & "De que Ihe falo assim?" \\
\hline B & $I_{B}(R)$ & $\begin{array}{l}\text { "Ponto de vista" de } \\
\text { B sobre R }\end{array}$ & $\begin{array}{l}\text { "De que ele me fala } \\
\text { assim?" }\end{array}$ \\
\hline
\end{tabular}

O quadro acima contempla as duas questões implícitas que dizem respeito ao "referente" o qual, como observa o autor, pertence igualmente às $\mathrm{CP}^{58}$. $\mathrm{O}$ autor faz questão de destacar que não se trata de realidade física e sim de um objeto imaginário (o ponto de vista do sujeito).

Posteriormente, no artigo A Propósito da Análise Automática do Discurso: atualização e perspectivas, Pêcheux e Fuchs (1997, p. 170-1) vão rever, entre outros pontos da AAD/69, a questão das CP do discurso, cujas formulações, segundo eles, eram ambíguas no texto de 1969 :

[...] esta ambigüidade residia no fato de que o termo "condições de produção" designava ao mesmo tempo o efeito das relações de lugar nas quais se acha inscrito o sujeito e a "situação" no sentido concreto e empírico do termo, isto é, o ambiente material e institucional, os papéis mais ou menos conscientemente colocados em jogo, etc. (...) as condições de produção neste último sentido determinariam "a situação vivida pelo sujeito" no sentido de variável subjetiva

${ }^{58}$ No texto, Pêcheux coloca as questões relativas ao referente em um quadro separado. Conf:: Pêcheux, op. cit, 1997, p. 84. 
("atitudes", "representações", etc) inerentes a uma situação experimental.

Os autores observam neste aspecto que a primeira definição se opõe à segunda da mesma forma que o real se opõe ao imaginário e, justamente, uma teoria deste imaginário em relação ao real foi o que faltou ao texto de 1969. Essa falta possibilitou inevitavelmente que as relações de lugar se confundissem com 0 jogo de espelhos de papéis interiores a uma instituição. Segundo eles, o que faltou e, em parte, ainda continua faltando "é uma teoria não-subjetiva da constituição do sujeito em sua situação concreta de enunciador." 59

Considerando essa constatação e tendo em vista as re-significações e reformulações que se presentificam nas fases 02 e 03 da AD, esta questão da teoria não-subjetiva da constituição do sujeito vai ser retomada por Pêcheux. Em Semântica e discurso - Uma crítica à afirmação do óbvio, o autor - retomando a expressão de L. Althusser - afirma que as ideologias constituem os indivíduos em sujeitos, isto é, a constituição do sujeito deve ser compreendida no interior da ideologia. Para o pesquisador francês $(1997$, p. 133) foi Althusser que,

[...] em Aparelhos Ideológicos de Estado, apresentou os fundamentos reais de uma teoria não-subjetivista do sujeito, como teoria das condições ideológicas da reprodução/transformação das relações de produção: a relação entre inconsciente (no sentido freudiano) e ideologia (no sentido marxista)[...]

Em outro momento, Pêcheux - ao ponderar sobre as interpretações e acobertamentos da filosofia idealista da linguagem que se fundamenta no efeito ideológico "sujeito" através do qual a subjetividade se constitui como origem ou causa em si - vai afirmar que uma teoria materialista dos processos discursivos que objetive alcançar suas pretensões não pode abrir mão de uma teoria não-subjetivista da subjetividade.

${ }^{59}$ Os aspectos que compreendem um repensar da noção de CP e outras categorias da AAD/69 poderão ser encontrados no artigo já referido A Propósito da Análise Automática do Discurso: atualização e perspectivas In: Pêcheux, op. cit, 1997, p.163 a 235. 
É possível perceber, portanto, nas pesquisas e estudos de Pêcheux uma trajetória teórica marcada pela reconfiguração de conceitos fundamentais que, tendo a identidade discursiva como meta, vão sendo minados pela questão da alteridade.

\subsubsection{CP - 'formações imaginárias' e atos de linguagem}

Em 1979, Osakabe, em seu livro Argumentação e Discurso Político, aborda a questão das $\mathrm{CP}$ do discurso, partindo de uma explicitação e reestruturação do quadro proposto por Pêcheux. Para o autor (1979, p. 46), se pensarmos a importância do texto dentro de uma perspectiva da linguagem em uso, inevitavelmente teremos de colocar "em evidência o problema das condições de produção como quadro de informação prévio e necessário a uma observação interna de cada realidade discursiva".

As discussões a respeito das CP estão fundamentadas, basicamente, em duas perspectivas distintas que provêm da Psicologia e da Sociologia. A produção pode, portanto, ser pensada tanto do ponto de vista de um produtor individualizado, quanto de um produtor socializado. Assim sendo, tentar uma análise em função de categorias fornecidas por uma dessas óticas, para Osakabe (p. 47), "parece ser muito mais um caso de projeção de interesse do que propriamente o da definição de classes características do próprio discurso."

Sem deixar de considerar que a opção por uma, ou outra ótica das CP de um texto existe e precisa ser levada em consideração, o autor levanta um questionamento: "em que medida a definição ou, melhor, a escolha de uma perspectiva determinada não restringe os próprios objetivos da análise?" ( p. 47). E, a partir daí, pondera se não seria mais importante pensar as CP de uma perspectiva mais "neutra" em relação a um interesse prévio para depois relacionar a essa produção as categorias fornecidas pela especialidade de interesse? Esclarece, em seguida, que, em seu trabalho, pretende pensar a questão das CP a partir de uma atitude mais "imparcial”, partindo do próprio interesse emanado pelo discurso.

Para isso, vai buscar na proposta de Pêcheux a esquematização prévia de alguns componentes fundamentais para a definição desse interesse próprio. $\mathrm{E}$ o faz em razão da opção deste pelo esquema informacional proveniente das teorias 
sociológicas e psicossociológicas da comunicação, que apresenta a vantagem de evidenciar os protagonistas do discurso e seu referente (p. 47).

A substituição do termo mensagem pelo termo discurso (grifos nossos), realizada por Pêcheux nesse esquema da teoria da informação, é fundamentalmente importante para os objetivos a que Osakabe se propõe em seu trabalho ${ }^{60}$. Tal importância se deve ao fato de que "a relação que se processa pela seqüência verbal emitida por um destinador em relação a um destinatário não é puramente informativa, mas abarca, além do "efeito de sentido" pensado por M. Pêcheux, uma relação de intersubjetividade"(p. 48)

Até aqui, os pensamentos de Pêcheux e Osakabe se aproximam. As diferenças se estabelecem a partir do momento em que aquele concebe destinador e destinatário como representantes de um lugar em uma dada formação social, assumindo um ponto de vista sociológico que, de certa forma, se compromete com um interesse determinado. Nessa perspectiva, o discurso assume características, que resultam, pura e simplesmente, das relações de papéis sociais determinados. Osakabe (1979, p. 48) acredita que:

[...] - mediando aquele esquema básico e os papéis sociais, e, funcionalmente, num plano mais fundamental que os papéis sociais - se encontrem outros elementos que podem ser definidos a partir do esquema de formações imaginárias fornecido pelo próprio $M$. Pêcheux.

A partir desse pressuposto e analisando o esquema de formações imaginárias criado por Pêcheux, vai propor uma reformulação das perguntas que compõem o chamado "jogo de imagens", por entender que carecem de outro elemento igualmente importante e que se fundamenta sobre a relação atuacional e pragmática entre A e B. Para Osakabe, a pergunta central não se localiza mais em $\mathrm{A}$ ou $B$, mas sobre $A$ e $B$, podendo ser assim construída: o que $A$ pretende falando dessa forma? Duas outras perguntas podem surgir do desdobramento desta questão. São elas: $O$ que $A$ pretende de $B$ falando dessa forma? O que A pretende

${ }^{60} \mathrm{O}$ foco do livro do prof. Osakabe é a análise exaustiva dos discursos de Getúlio Vargas, com a finalidade de "averiguar as aproximações e as rupturas possíveis entre o discurso político nitidamente pragmático e o discurso político-teórico, a fim de não se circunscreverem as conclusões numa tautologia (metaforicamente falando), onde, partindo de um tipo de discurso, se ocupasse somente de sua definição, dada já de início." Conf.: OSAKABE op. cit. 1979, p. 45. 
de A falando dessa forma? São questionamentos que introduzem um novo elemento nas condições gerais de produção.

Esse novo elemento se instaura, tendo em vista que as perguntas "colocam em jogo não apenas a imagem que A e B fazem de si, entre si, ou sobre o referente, mas também a própria natureza do ato que A pratica ao falar de determinada forma e da natureza do ato a que A visa em B" (p. 50). Esses aspectos reportam-nos a questão dos atos de linguagem, "cuja pertinência às condições de produção se afigura como fundamental"(p.50).

A inserção da questão dos atos de linguagem como fundamental para as CP do discurso constitui o diferencial de Osakabe sobre a definição dessa noção. Para que possamos entender melhor em que aspectos essa particularidade proposta pelo professor da Unicamp se estabelece e que importância tem dentro do quadro teórico que ele propõe para seus corpora, importa ressaltar, como observa o estudioso, "uma seleção dos aspectos mais relevantes dos atos de linguagem para o estudo das condições de produção”.

Fazendo uma reflexão sobre a concepção ${ }^{61}$ que, por longo tempo, foi defendida por filósofos e gramáticos em relação ao papel de uma declaração, Austin argumenta que atualmente muitas das sentenças que dentro dessa concepção eram aceitas incontestavelmente como "declarações", tanto pelos filósofos quanto pelos gramáticos, foram reanalisadas com grande empenho, principalmente em filosofia, de forma processual. Primeiramente, preconizou-se que toda declaração deveria ser "verificável", levando à conclusão de que muitas "declarações" se configuram como pseudodeclarações. Este primeiro passo permitiu a conclusão de que muitas "declarações" eram sem sentido, apesar de sua forma claramente gramatical.

\footnotetext{
${ }^{61}$ Por muito tempo, os filósofos acreditaram que a função de uma declaração era somente a de "descrever" um estado de coisas ou declarar um fato, sempre em uma condição de verdade ou falsidade. Já os gramáticos indicavam de forma sistemática que nem todas as sentenças são empregadas para fazer uma declaração, pois além das declarações existem perguntas e exclamações, bem como aquelas sentenças que expressam ordens, concessões ou desejos. Austin acredita que filósofos e gramáticos sempre compreenderam que não era fácil fazer uma distinção precisa entre uma pergunta e/ou uma ordem e uma declaração, valendo-se dos poucos e incipientes critérios gramaticais de que dispunham. Considera possível que não tenha sido dada a devida atenção aos problemas que esse fato evidencia. Para ele persiste a dúvida sobre como definir qual é a pergunta, qual é a ordem, qual é a declaração. Quais são os limites e as definições de cada uma? Conf.: AUSTIN, J. L. Quando dizer é fazer. Trad.: Danilo Marcondes de Souza Filho. Porto Alegre: Artes Médicas, 1990, I Conferência, p. 21 e 22.
} 
Segundo Austin (1990, p. 22), era necessário, entretanto, estabelecer limites para se admitir uma sentença como sendo sem sentido. Esta reflexão levou, em um segundo estágio, ao questionamento: será que muitas das aparentes pseudodeclarações são realmente "declarações"? A análise que buscava a resposta a este questionamento encaminhou a reflexão para duas conclusões:

1. a constatação de que "muitos proferimentos que parecem declarações não têm, ou têm apenas em parte, o propósito de registrar ou transmitir informação acerca dos fatos;

2. o reconhecimento de que, muitas vezes, usamos proferimentos cujas formas excedem pelo menos os limites da gramática tradicional.

Com o intuito de esclarecer essas questões, Austin (p. 22-3) lança mão de alguns exemplos, afirmando, em seguida, que:

[...] Já se reconhece que muitas palavras que causam notória perplexidade quando inseridas em declarações aparentemente descritivas (...) são usadas para indicar (e não para relatar) as circunstâncias em que a declaração foi feita, as restrições às quais está sujeita ou a maneira como deve ser recebida [...].

Segundo o autor (p. 23), não considerar essas possibilidades, como era de costume anteriormente, é uma falácia "descritiva", ou melhor, "constatativa", já que nem todas as declarações verdadeiras ou falsas são descrições.

Essas conclusões encaminham os estudos de Austin para a sua proposta em relação à caracterização dos enunciados em performativos e constatativos ${ }^{62} \mathrm{e}$ aos atos de linguagem. Como observa Osakabe, o filósofo inglês foi o primeiro estudioso a ver a linguagem conforme um quadro hipotético de atos de linguagem, pensando-os no interior de "um quadro empírico mais amplo e mais concreto", ou seja, a partir de uma perspectiva discursiva, considerando-se o que o próprio filósofo afirma: "O ato de discurso integral, na situação integral de discurso, é, no final das contas, o único fenômeno que procuramos elucidar de fato."63

\footnotetext{
${ }^{62}$ Osakabe, bem como grande parte dos estudiosos usam a variante "constativos". Acompanharemos estes pesquisadores, usando, a partir de agora, a expressão contativos.

${ }^{63}$ Esta citação que reproduzimos é a que foi traduzida e utilizada pelo prof. Osakabe da obra Quand dire c'est faire, - tradução francesa. Na tradução para a língua portuguesa, a citação apresenta algumas alterações de expressões que não alteram o efeito de sentido desejado pelo autor: "O ato de fala total na situação de fala total é o único fenômeno que, em última instância, estamos procurando elucidar.", XII Conferência, p. 121.
} 
O objetivo de Austin era o de construir uma teoria da significação que se distanciasse daquela fundamentada no critério da verdade ou falsidade dos enunciados. Coloca inicialmente em evidência a existência de certos enunciados que, nas circunstâncias apropriadas (e só nestas circunstâncias) não descreve o ato de dizer o que diz, nem o declara: pratica-o. A estes enunciados denomina de performativos em contraposição aos constativos que correspondem às asserções clássicas.

Segundo Osakabe (p. 51), as reflexões do filósofo inglês sobre esses dois tipos de enunciado levam:

[...] a observar a existência clara, no caso dos performativos, de uma base de significação somente definível a partir de seu conceito de atos de linguagem (...) o sujeito falante procede a três atos fundamentais no momento em que fala: primeiramente, ele procede a um ato de locução (fonética, gramatical e semântica); em segundo lugar, ele procede a um ato de ilocução (produzido pelo próprio ato de falar, palpável, por exemplo, no caso dos performativos, quando, num enunciado do tipo "eu prometo", o ato ilocucionário da promessa se realiza em se dizendo); e, em terceiro lugar, o ato de perlocução (produzido pelo fato de dizer, isto é, como decorrência do ato de dizer) (grifos do autor).

Outros aspectos da teoria de Austin são destacados pelo autor (p. 51), a saber:

1. ao encontrar dificuldade para estabelecer uma distinção entre atos ilocucionários e perlocucionários, o filósofo inglês recorre ao papel da convenção, definindo aqueles como convencionais (obedecem a regras instituídas) e estes como não convencionais;

2. por outro lado, o estudo dos atos de ilocução possibilitam a Austin amenizar, até certo ponto, a distinção inicial entre os enunciados constativos e performativos, ressaltando que ambos têm uma base ilocucionária, isto é, "à medida que, dizendo alguma coisa, faz-se alguma coisa além de dizer";

3. conclui que os enunciados constativos, contrariando a lógica clássica em determinadas condições, estão sujeitos não só ao critério da sua veracidade, mas também a veracidade de sua enunciação resulta das condições de sua produção; 
4. as preocupações de Austin centram-se nos atos ilocucinários, pois neles estão as razões de sua inovação, tendo em vista que pretende, em sua obra, demonstrar que os enunciados constativos - sobre os quais se fundamenta a lógica tradicional - constituem-se em uma abstração falseada daquilo que caracteriza a linguagem;

5. em conseqüência, não avança em relação às questões pertinentes aos atos perlocucionários;

6. também Searle - que se inspirou nos trabalhos de Austin e procurou avançar em relação aos atos de linguagem - dá primazia ao ato ilocucinário, fazendo referência aos perlocucionários para caracterizá-lo como seqüência dos atos ilocucionários.

O pesquisador brasileiro defende, entretanto, que - do ponto de vista do discurso - os atos perlocucionários são extremamente relevantes e por esse motivo se propõe a discuti-los com muita atenção em sua pesquisa. Para ele, duas vertentes revelam essa importância dos perlocucionários. A primeira resulta da discussão teórica presente na Introdução de seu trabalho e a segunda procede do próprio material a que o pesquisador se propôs analisar: o discurso político.

No que se refere à questão teórica de que trata a primeira vertente, discutiu, entre outras coisas, a perspectiva de vários estudiosos ${ }^{64}$ sobre a noção de discurso e sobre subjetividade. Dessa reflexão pôde chegar a dois pontos de vista sobre o discurso ${ }^{65}$ : o de sua natureza e o de sua extensão ${ }^{66}$. O destaque dado por Osakabe - nesta primeira vertente - se refere ao discurso do ponto de vista de sua natureza.

A natureza do discurso caracteriza-se por uma participação, em maior ou menor escala, das relações entre um eu e um tu, que significa - além do processo de contato entre locutor e ouvinte - a existência de um mecanismo que, estruturalmente, manifeste, não só o papel do locutor enquanto agenciador do discurso, mas principalmente, como afirma Osakabe (1979, p. 53), a importância que tem o ouvinte nesse agenciamento, de tal forma que

\footnotetext{
${ }^{64}$ A discussão teórica desenvolvida por Osakabe na introdução de seu livro contempla uma reflexão sobre as idéias de Geneviève Provost, Z. Harris, M. Pêcheux e Emile Benveniste.

${ }^{65}$ Retornaremos a esta questão no item que trata da noção do discurso.

66 Maiores detalhes sobre esta questão podem ser encontrados na obra: OSAKABE, $\mathrm{H}$. Argumentação e Discurso Político. 1aㅡ edição. São Paulo-SP: Kairós, 1979, p.7 a 38.
} 
[...] se num primeiro nível de análise é o locutor que se coloca em evidência, num nível mais profundo, é possível observar que o ouvinte é um agente por tabela do discurso na medida em que é nele que se justifica o próprio discurso (...) Um eu não define, por si só, a ação a ser empreendida: é preciso que ele tenha sua imagem do tu ou que o tu forneça essa imagem (grifos nossos).

A definição da imagem do ouvinte encaminha à definição de um tipo de ação que visa alguns resultados no próprio ouvinte. Além disto, como observa Osakabe (p. 53), "o discurso tem sua semanticidade garantida situacionalmente, isto é, no processo de relação que se estabelece entre as suas pessoas e a situação", ou seja, a construção do sentido de um discurso depende do quadro situacional em que se insere.

Com essa posição o autor pretende simplesmente indicar que uma análise interpretativa precisa sempre levar em conta as significações que procedem das relações entre os protagonistas do discurso e a situação. Isso porque é dessas relações, somadas àquelas instauradas entre os interlocutores, "que se definem algumas significações básicas ligadas à pragmática discursiva; logo, às significações ligadas aos atos de linguagem" (p. 53). Não é possível determinar antecipadamente se um discurso tem por objetivo edificar ou persuadir sem que sejam consideradas as características básicas da situação e das relações entre os interlocutores. Dessa maneira, para Osakabe (1979, p. 53-4)

[...] parece que o quadro das perlocuções que caracterizam a própria intenção pragmática do discurso não pode ser definido arbitrariamente. Ao contrário do que afirma Austin, 0 ato perlocucionário é também convencional na medida em que se subordina a determinadas regras contextuais.

Só é possível estabelecer a diferença entre um ato de persuadir e um ato de convencer se considerarmos - além da escolha dos meios para levar o ouvinte a aceitar determinada posição proposta — a distinção dos contextos.

Utilizando-se de exemplos do próprio corpus que escolheu como objeto de pesquisa, Osakabe (p. 54-8) pontua outros aspectos sobre os atos de linguagem, dentre os quais destacamos os seguintes: 
a) Não se pode pensar o discurso enquanto realização de um único ato de linguagem, mas como constituído pela dominância de um ato sobre os outros.

b) O fato de ter destacado a importância dos atos perlocucionários para a compreensão dos discursos não diminui a importância que têm os atos ilocucionários para essa mesma compreensão. A importância destes atos enfrenta, entretanto, dificuldades ao nível do discurso todo, já que, de um modo geral, seus estudos têm sido realizados sobre expressões que apresentam explicitamente verbos que exprimem esses atos ilocucionários.

c) A solução mais viável, portanto, para equacionar a importância dos ilocucionários em relação ao discurso será a de determinar estes atos somente após a determinação dos atos perlocucionários.

d) Dessa maneira, em relação ao discurso, uma regra geral para a definição dos atos ilocucionários está intimamente ligada ao efeito perlocucionário, o qual proporciona as condições gerais para a obtenção do ato ilocucionário.

e) É procedente considerar, portanto, o ato perlocucionário como condição fundamental do ato ilocucionário, quer enquanto formulação explícita quer enquanto condição pressuposta.

Após esse estudo sobre os aspectos mais relevantes dos atos de linguagem, o autor retoma o quadro formulado por Pêcheux em que este apresenta as questões cuja resposta proveria o jogo de imagens que garantiriam a produção do discurso. E lembra que postulou inicialmente a necessidade de, além da configuração das imagens, uma determinação da natureza do ato que o locutor pretende colocar em prática ao falar e a relação deste com o ouvinte. Outro aspecto levantado por Osakabe (p.58), no reexame dos atos de linguagem, foi o destaque para a importância fundamental que "têm para o discurso os atos perlocucionários em relação aos atos ilocucionários".

Diante disso, reformula o quadro sugerido por Pêcheux, salientando a importância de "uma definição da natureza do ato que o locutor visa praticar pela fala e a relação deste com o ouvinte, na discussão sobre as condições de produção" e tratando estritamente das perguntas formuladas na última coluna à direita, que ficaram assim formuladas:

1. Qual imagem faço do ouvinte para lhe falar dessa forma? 
2. Qual imagem penso que o ouvinte faz de mim para que eu the fale dessa forma?

3. Que imagem faço do referente para Ihe falar dessa forma?

4. Que imagem penso que o ouvinte faz do referente para lhe falar dessa forma?

5. Que pretendo do ouvinte para Ihe falar dessa forma?

Como é possível observarmos, a reformulação consistiu em acrescentar a questão relativa aos atos de linguagem e, levando em conta os objetivos da própria pesquisa, retirar do quadro elaborado por Pêcheux (1997, p. 83-4) as questões relativas à recepção, ou seja, aquelas centradas no ouvinte: "Quem sou eu para que ele me fale assim? Quem é ele para que ele me fale assim? De que ele me fala assim?" Segundo o autor, a retirada dessas questões se justifica em razão delas só se configurarem importantes em um esquema bem mais amplo, que compreenderia as condições de produção e as de recepção, que definiriam a estratégia global do discurso.

As duas primeiras questões dizem respeito aos pressupostos de natureza diversa que podem ser evidenciadas no próprio discurso e sua resposta está sujeita ao interesse dominante que evidencia o próprio discurso individual. A terceira e a quarta questão compreendem a imagem que o locutor tem do referente e a imagem que pensa que o ouvinte tem desse mesmo referente.

A questão cinco reporta-se aos atos de linguagem e visa à busca de significações externas mais amplas ${ }^{67}$ do que aquelas presentes no texto. Como observa o autor, essas significações externas o são a partir do momento em que colocam em evidência o discurso enquanto lugar de interação entre locutor e ouvinte, dependendo totalmente daquilo que é dito num discurso.

São essas significações as responsáveis pela definição dos efeitos a serem alcançados com o ouvinte e manifestam-se através dos atos perlocucionários convencer, persuadir, impressionar (grifos nossos), que condensam, na sua totalidade, todos os efeitos a serem alcançados. Só a partir daí torna-se possível

${ }_{67}$ Isso vai ocorrer se, dentro dos limites dessas significações externas ou das direções por elas fornecidas, for possível serem equacionadas as significações internas ao texto e sua estruturação. 
pensar em uma análise que compreenda uma significação como a dos atos ilocucionários.

Portanto, dois tipos de informações são buscadas em uma análise das CP de um discurso: "as imagens mútuas sobre as quais o locutor constrói seu discurso e os atos de linguagem a que se visam com a realização do discurso"(Osakabe, 1979, p. 60)

Considerando que seu objetivo em seu trabalho não é o de tratar exaustivamente a questão da organização de um quadro geral de imagens possíveis para sustentar a produção do discurso, mas simplesmente apresentar um encaminhamento possível para essa atividade, Osakabe (p. 60) destaca a relevância desta para a compreensão do discurso que está em entender que:

[...] à parte a finalidade específica que garante sua motivação, o locutor tem a necessidade de ter também garantido certo número de significações que considera suficientemente aceitas e assimiladas no ouvinte, cujo desconhecimento pode levar o ouvinte a simplesmente recusar o discurso que lhe é dirigido.

Nessa questão, ressalta ser Ducrot um dos raros lingüistas que atentou para a importância desse fato, no momento que investiga a respeito daquilo que não é explicitado pela linguagem e apresenta sua proposta de análise dos enunciados a partir da distinção entre o subentendido e a pressuposição, apontando a especificidade discursiva daquele e a especificidade lingüística desta. Fazendo uma breve discussão sobre estes pontos, Osakabe vai, em seguida, analisar vários textos de seu corpus com a finalidade de legitimar as reflexões que fez sobre a questão das $\mathrm{CP}$ e sua reformulação.

Finaliza sua incursão sobre as $\mathrm{CP}$, resumindo que estas podem ser definidas de acordo com três critérios complementares: o primeiro é o das imagens pressupostas, que o locutor faz do ouvinte e este do locutor; o segundo é aquele da imagem que o locutor faz do referente e da suposta imagem que o ouvinte faz desse mesmo referente; o terceiro, o da intenção do ato que o locutor pretende praticar sobre o ouvinte e do ato que pratica para atingir o resultado pretendido. 


\subsubsection{CP - a articulação ao conceito de formação discursiva}

Posteriormente, Courtine ${ }^{68}$ vai tratar da noção de CP do discurso, tomando como ponto de partida as origens dessa noção que antecedem a formulação de Pêcheux. Segundo ele, as origens das CP são de três ordens:

1. primeiramente tem sua origem na análise de conteúdo, da maneira que esta é praticada especialmente em psicologia social;

2. em segundo lugar, origina-se de forma indireta da sociolingüística na medida em que esta reconhece as variáveis sociológicas ("o estado social do emissor, o estado social do destinatário, as condições sociais da situação de comunicação [...] os objetivos do pesquisador...") como responsáveis pelas CPs do discurso;

3. a terceira origem se situa no artigo de Harris, Discourse Analysis (1969), e se configura como uma origem implícita, tendo em vista que o termo CP não figura no texto e sim o termo situação, colocado em correlação ao de discurso, quando se trata de considerar como fazendo parte deste. Apenas as frases, que foram proferidas ou escritas umas após outras por uma ou várias pessoas em uma dada situação. Ou, ainda, de estabelecer a correlação entre as características individuais de um enunciado e as peculiaridades de personalidade provenientes da experiência do indivíduo em "situações interpessoais condicionadas socialmente".

Segundo o estudioso francês, essa noção de situação elaborada por Harris se mostra insuficiente e muito semelhante à noção de CP postulada pela análise de conteúdo da psicologia social ou pela sociolingüística.

As transformações da noção de $\mathrm{CP}$, que se sucedem, compreendem dois conjuntos de definições:

1. o primeiro conjunto, chamado por Courtine como definições empíricas é aquele em que as $\mathrm{CP}$ do discurso tendem a se confundir com a definição empírica de uma situação de enunciação;

${ }^{68}$ Para esboçarmos o pensamento de Courtine sobre CP, utilizamos textos sobre o assunto em: BRANDÃO, op. cit. 1994, p. 35 a 37 e COURTINE, J.J.. "La notion de "condition de Production du Discours". In: Analyse du discours politique (le discours communiste adress aux chrétiens). Langages 62, juin, 1981, Paris, Larousse, p. 19-32. 
2. o segundo é composto de um conjunto de definições teóricas, que aparecem na $A D$ desde 1971 junto à noção de "formação discursiva" (HAROCHE, et. all, 1971, p. 102).

Em seguida, Courtine apresenta uma síntese da proposta de Pêcheux, qualificando-a como a primeira definição empírica geral da noção de CP. Essa tentativa de definição geral tem - como já explicitado - as relações entre os lugares determinados socialmente representadas, no discurso, por uma série de "formações imaginárias" que representam o lugar que destinador e destinatário se atribuem cada um a si e ao outro.

Em uma situação concreta de comunicação, essas relações e a representação subjetiva desses lugares abriram espaço para interpretações que ressaltam o domínio do elemento imaginário sobre as determinações objetivas que caracterizam um processo discursivo (COURTINE, 1981, p. 21).

Para Courtine (p. 21-2) a ambigüidade da própria noção de CP ocasionada, de um lado, pelo recurso ao esquema de comunicação de Jakobson que possibilita "compreender as condições (históricas) de produção de um discurso como as circunstâncias da produção (no sentido psicolingïstico do termo) de uma mensagem por um sujeito falante" e, por outro lado, pelo fato de que essas formulações não resultam de um desdobramento de tarefas realizado espontaneamente em AD pelo qual as CP recebem sua caracterização da psicologia ou da sociologia - autoriza essas interpretações. Segundo o autor os termos "imagem" e "formação imaginária" poderiam ser substituídos pela noção de "papel" da mesma forma que ela é aplicada nas "teorias do papel" herdadas da sociologia funcionalista de T. Parsons ou ainda do interacionismo psicossociológico de Goffman.

Portanto, para Courtine, a noção de CP delineada por Pêcheux não rompe com as origens psicossociológicas da noção, anteriormente especificadas. Diante disso, propõe uma definição que se distancie da "irresistível atração" que toda pesquisa evidencia por uma noção das CP em que prevalece a referência a uma situação psicossocial de comunicação.

Segundo Courtine (p. 23), nessa perspectiva, o caráter heterogêneo e instável da noção de CP torna-a o lugar de uma operação psicologizante das 
determinações históricas do discurso, que ameaça transformar essas determinações em simples circunstâncias. Circunstâncias estas "em que interagem os 'sujeitos do discurso', o que leva, ao mesmo tempo a situar no 'sujeito do discurso' a fonte de relações das quais ele é apenas o portador ou o efeito". Defende, então, uma redefinição da noção de CP que esteja no mesmo patamar da análise histórica das contradições ideológicas evidenciadas na materialidade discursiva e articulada ao conceito de formação discursiva.

As CP do discurso continuam e vão continuar sendo alvo das atenções dos pesquisadores, se não por outro aspecto, porque no curso da história elas, como toda e qualquer categoria teórica, são entendidas sempre em processo.

O que o estudo dessas CP nos afirma/confirma é que a comunicação não implica somente a língua e sua estrutura. É fundamental levar em consideração a posição do sujeito da enunciação, qual sua função no ato da enunciação, as circunstâncias que dizem respeito ao contexto imediato e ao contexto sócio-histórico, ideológico em que o discurso foi produzido. Tendo em vista que os sentidos são regulados socialmente e não são construídos só da materialidade discursiva, mas das relações que se estabelecem entre enunciador e enunciado, bem como das determinações não-lingüísticas que envolvem a enunciação, estas questões são muito importantes por serem determinantes do significado.

\subsubsection{O objeto: o discurso}

A considerar pelo vasto uso da palavra discurso em textos sobre a linguagem, poder-se-ia pensar que a noção desse termo é notadamente clara para os usuários da língua, no entanto, é uma palavra cujo sentido ainda pode ser considerado muito complexo e um tanto vago. Recorremos a Osakabe e a Possenti que muito bem colocaram esta questão sobre o discurso, retratando uma realidade que corresponde ao final das décadas de 70 e 80, respectivamente. Ainda que em escala menor, compreendemos que essa mesma realidade se reflete atualmente.

Em relação ao termo discurso, Osakabe $(1979$, p. 7$)$ assim se coloca: 
deva ao fato de ter sido ela utilizada em trabalhos com alguma preocupação científica, onde simplesmente se recuperou o próprio uso que se fez dela na linguagem ordinária. Esse processo acabou por configurá-la como referindo-se a um domínio suficientemente amplo de investigação de tal forma que dentro dele coubessem os mais diferentes interesses científicos.[...] é também comum encontrar essa palavra empregada para designar, inclusive, fenômenos pertencentes a domínios perceptivos distintos (discurso literário, discurso musical, discurso cinematográfico, etc.).

E completa:

Se, de um lado, esse uso pluralizado do termo constitui sintoma da grande atenção de que são atualmente objetos as manifestações verbais e não-verbais, portadoras de uma rede intrincada de significações, de outro lado, provoca, pela própria complexidade, um movimento de contínuos ajustes conceituais da parte de seus pesquisadores.

O termo discurso para Possenti (1988, p. 1)

[...] continua vago. Aliás, é cada dia mais vago. Está se transformando numa espécie de lixeira para onde se recolhem os restos da lingüística, sejam os restos que sobram de uma gramática ou estrutura [...] resume-se aos restos que sobram das tentativas de operar cientificamente, isto é, com regras gerais, sobre os dados lingüísticos.

Os dois pesquisadores levantam essa questão justamente ao iniciarem uma reflexão sobre as noções de discurso que compreendem as postulações teóricas em que acreditam, como também para situá-las no domínio das investigações que se propuseram a fazer e que resultaram nos livros referidos aqui. Ao tratarmos mais especificamente da noção de discurso, estaremos nos referindo àquelas defendidas pelos autores acima citados.

Nosso objetivo não é fazer um histórico do percurso investigatório dos sentidos atribuídos ao discurso, pois muitos já o fizeram muito bem. Pontuaremos, entretanto, alguns aspectos e algumas noções principalmente aquelas de autores que trabalham com a $A D$, ou dela se aproximam, tendo em vista ser este um 
conceito fundante para esta disciplina e, conseqüentemente, para toda análise que se pretenda fazer dessa perspectiva.

A filosofia clássica - na qual o conhecimento intuitivo contrapunha-se ao conhecimento discursivo - já utilizava a noção de discurso (MAINGUENEAU, op. cit., 2004, p. 168), mas foi com a expansão das correntes pragmáticas que o termo teve um significativo impulso. Para Charaudeau \& Maingueneau, a partir da década de 80, o termo discurso tem se propagado nas ciências da linguagem e essa propagação "é o sintoma de uma modificação no modo de conceber a linguagem. Falando de 'discurso', toma-se implicitamente posição contra uma certa concepção da linguagem e da semântica" (grifos dos autores, p. 169-170).

Com o enfraquecimento do estruturalismo e a ascendência das teorias nãosubjetivas da linguagem, a noção de discurso, conseqüentemente, vai se construindo/reconstruindo dentro desses novos parâmetros. O entendimento deste termo vai, portanto, variar de acordo com os diferentes enfoques das tendências e/ou correntes teóricas que discutem/pesquisam a noção de discurso, dessa perspectiva.

Foucault, em sua obra A Arqueologia do Saber (1995), concebe, o discurso como uma dispersão, entendido no interior de uma teoria não-subjetiva, ou seja, onde o sujeito não é o senhor do seu discurso, ao contrário, é descentrado, dividido; é uma pequena parte de um corpo histórico-social no interior do qual constrói o seu discurso da/na interação com outros discursos, seja para deles se apossar, seja para diante deles posicionar-se ou ser posicionado. Segundo o autor (p. 61-2),

[...] o discurso, assim concebido, não é a manifestação (...) de um sujeito que pensa, que conhece, e que o diz: é, ao contrário, um conjunto em que podem ser determinadas a dispersão do sujeito e sua descontinuidade em relação a si mesmo. É um espaço de exterioridade em que se desenvolve uma rede de lugares distintos.

Segundo Brandão (1994, p. 28), "cabe à Análise do discurso descrever essa dispersão, buscando o estabelecimento de regras capazes de reger a formação dos discursos". As regras a que se refere Brandão (p. 28) são nomeadas por Foucault de "regras de formação" e facultam a definição dos elementos que engendram o discurso, tais como: 
[...] os objetos que aparecem, coexistem e se transformam num "espaço comum" discursivo; os diferentes tipos de enunciação que podem permear o discurso; os conceitos em suas formas de aparecimento e transformação em um campo discursivo, relacionados em um sistema comum; os temas e teorias, isto é, o sistema de relações entre diversas estratégias capazes de dar conta de uma formação discursiva, permitindo ou excluindo certos temas ou teorias.

Portanto, ao se apresentarem como um conjunto das redes de relações que se estabelece entre objetos, tipos de enunciação, conceitos e estratégias, essas regras determinam a "formação discursiva", caraterizando-a em sua singularidade e tornando possível a passagem da dispersão para a regularidade. Essa regularidade é alcançada através da análise dos enunciados que compõem a formação discursiva.

Mais adiante, Foucault (1995, p. 135-6) vai chamar de discurso a um conjunto de enunciados que pertencem à mesma formação discursiva;

[...] ele não forma uma unidade retórica formal, indefinidamente repetível e cujo aparecimento ou utilização poderíamos assinalar (e explicar, se for o caso) na história; é constituído de um número limitado de enunciados para os quais podemos definir um conjunto de condições de existência (...) é, de parte a parte, histórico fragmento de história, unidade e descontinuidade na própria história, que coloca o problema de seus próprios limites, de seus cortes, de suas transformações, dos modos específicos de sua temporalidade, e não de seu surgimento abrupto em meio às cumplicidades do tempo.

O discurso para Foucault (1996, p. 10) é gerador de poder, esse visto como causa de uma luta política: "o discurso não é simplesmente aquilo que traduz as lutas ou os sistemas de dominação, mas aquilo por, pelo que se luta, o poder do qual nos queremos apoderar". O autor (1995, p. 136) explicita que o discurso em seu trabalho é tomado como prática discursiva que não pode ser confundida "com a operação expressiva pela qual um indivíduo formula uma idéia, [...] nem com a 'competência' de um sujeito falante, quando constrói frases gramaticais”, mas é definida como: 
[...] um conjunto de regras anônimas, históricas, sempre determinadas no tempo e no espaço, que definiram, em uma dada época e para uma determinada área social, econômica, geográfica ou lingüística, as condições de exercício da função enunciativa.

No movimento dos estudos da linguagem, Pêcheux, por sua vez, vai defender uma noção de discurso como um efeito de sentido entre locutores, que precisa ser entendido em sua materialidade lingüística e histórica, sempre compreendido em relação a um conceito fundamental para a AD: o de formação discursiva.

No texto que produziu com Fuchs, ressalta dois equívocos complementares que devem ser evitados em relação ao termo "discurso". Deve-se evitar, em primeiro lugar, confundir discurso e fala (no sentido saussuriano: dicotomia; língua/fala) ${ }^{69}$, já que a teoria do discurso e os procedimentos a que se dedica não se identificam com uma "lingüística da fala". Outro equívoco que se opõe ao anterior, porque "distorce no outro sentido" a significação do termo "discurso" é aquele que o vê como um elemento particular do sistema da língua, tratado com indiferença pela "lingüística clássica".

Dessa maneira, para Pêcheux (1997, p. 178-9):

[...] o nível do discurso se integraria à língua, por exemplo, sob a forma de uma competência de tipo particular, cujas propriedades variariam em função da posição social, o que equivaleria à idéia de que existem línguas (...) politicamente justas mas lingüisticamente discutível $[\ldots]$

Esses problemas em relação à noção de discurso levam o autor a estabelecer uma distinção entre a base lingüística e o processo discursivo, o qual fundamenta seu desenvolvimento sobre aquela base. Dessa maneira, para Pêcheux (1997ª , p. 91), essas noções são opositivas e muito importantes:

a) a noção de base lingüística abrange todo o sistema lingüístico enquanto conjunto de estruturas fonológicas, morfológicas e sintáticas, beneficiado com uma autonomia relativa, regida por leis internas que constituem o objeto da Lingüística;

${ }^{69}$ Segundo Pêcheux, neste caso "o discurso seria a realização em atos verbais da liberdade subjetiva que 'escapa ao sistema' (da língua)" - op. cit., 1997, p.178. 
b) a noção de processo discursivo se desenvolve sobre a base dessas leis internas, não sendo possível concebê-lo como um pensamento absoluto que só faria uso "acidentalmente" dos sistemas lingüísticos. Nem pensar a discursividade como fala, isto é, uma maneira individual "concreta" de habitar a "abstração" da língua.

Segundo Brandão (1994, p. 34) a atenção de Pêcheux está voltada para inscrever o processo discursivo em uma relação ideológica de classes, pois constata, citando E.Balibar ${ }^{70}$, que as classes sociais não são indiferentes à língua, embora esta o seja em relação àquelas e a sua luta, a qual usam em consonância como o campo de seus antagonismos.

Essa distinção fundamental possibilita reconhecer, como observa a autora, primeiramente que "a língua constitui a condição de possibilidade do 'discurso'”, por ser um tipo estável presumida por todas as condições de produção passíveis de serem realizadas em um momento histórico determinado. Em segundo lugar, que os processos discursivos se constituem na origem da produção dos efeitos de sentido no discurso e a língua é o lugar material em que se constroem os efeitos de sentido.

Dessa maneira, se o processo discursivo é produção de sentido, discurso vai ser o espaço em que se constroem as significações, sendo as formações discursivas o lugar especifico da constituição desses sentidos (p. 35).

Em momento mais recente, o discurso vai ser objeto de reflexão para outros pesquisadores. Osakabe, por exemplo, define-o a partir de dois pontos de vista: o de sua natureza e o de sua extensão. Do ponto de vista de sua natureza, o discurso caracteriza-se:

a) por uma maior ou menor participação das relações entre um eu e um tu;

b) por uma maior ou menor presença de indicadores de situação;

c) considerando sua pragmaticidade, como sendo necessariamente significativo, tendo em vista que só se pode compreender sua constituição inserida em um processo pelo qual eu e tu se aproximam pelo significado;

\footnotetext{
${ }^{70}$ Citação de Pêcheux: "O fato de que a língua seja 'indiferente' à divisão de classes e a sua luta, não quer dizer que as classes sejam 'indiferentes à língua. Ao contrário, elas a utilizam, de modo determinado, no campo de seu antagonismo, especialmente da sua luta política" - E. Balibar, Marxisme et linguistique (1950), Cahiers marxistes-leninistes, 1966, ํㅡ 12-13, p.21-2.
} 
d) por ter sua semanticidade construída no processo interacional que se instaura entre suas pessoas (eu/tu) e as pessoas da situação, entre seus indicadores de tempo, lugar, etc. e o tempo, lugar, etc. da própria situação.

Do ponto de vista de sua extensão, o discurso, segundo o autor, apresenta dois aspectos a serem considerados:

a) primeiramente, constitui-se em uma entidade mais ampla do que a frase (salvo alguma frase que possa vir a ser qualificada como discurso);

b) em segundo lugar, está demarcado por dois brancos semânticos, que se deve à falta de uma cadeia significativa que o constitui, ou à alteração do locutor.

Alguns aspectos chamam atenção na noção construída por Osakabe e a diferenciam da apresentada pela maioria dos pesquisadores. O primeiro diz respeito à caracterização do discurso em dois pontos de vista: quanto a sua natureza e quanto a sua extensão. O outro aspecto compreende a superfície discursiva apresentada através de uma enumeração. Enumeração esta que não deixa ao leitor a idéia de fragmentação, pelo contrário, possibilita, na articulação do conjunto das características, a construção do sentido pretendido e evidencia a concepção de linguagem que fundamenta essa noção. E, finalmente a questão da delimitação do discurso "por dois brancos semânticos" defendida pelo autor, mas que nem sempre é consensual e nem considerada relevante para outros estudiosos.

Outro estudioso que se posiciona em relação ao discurso é Geraldi (1996, p. 9-23). Em seu artigo Discurso e sujeito, o autor considera o processo de produção do discurso como "o conjunto de mecanismos formais que produzem um discurso de tipo dado em 'circunstâncias' dadas", com base no fundo invariante das coerções da língua e nas "condições de produção" próprias de cada situação. Segundo o autor, a relação dicotômica língua/fala cede lugar a uma divisão tricotômica língua/discurso/fala, sendo o conceito intermediário "construído como o lugar da definição da relação entre a invariabilidade da língua, cuja autonomia relativa é reconhecida, e a variabilidade da fala, cuja dependência a um discurso dado é estatuída" (p. 16).

Geraldi (1996, p. 18), defendendo a concepção de linguagem como uma atividade constitutiva, vai ressaltar a importância do trabalho lingüístico, considerando que por este trabalho "a linguagem se constitui marcada pela história 
deste fazer contínuo que a está sempre constituindo". E mais, para o autor, o lugar privilegiado deste trabalho é a interação verbal que acontece no interior das interações sociais, das quais é apenas um tipo, mas, ressalte-se: um tipo essencial.

No entender do autor, se o trabalho lingüístico se concretiza nos processos interativos, é preciso considerar que aí há agentes, fato que aponta para a necessidade de se pensar uma teoria do sujeito e, inspirado em Bakhtin, o autor entende que o sujeito se constitui na interação com os outros, internalizando a linguagem e constituindo-se como ser social, num processo de "nunca acabar", pois "a linguagem não é trabalho de um artesão, mas trabalho social e histórico seu e dos outros e para os outros e com os outros que ela se constitui".

Desta perspectiva, Geraldi (p. 19) considera que o acontecimento discursivo (grifos nossos) - em sua densidade, precariedade e singularidade — será entendido diferentemente da condição de "mero acidente de uso da expressão verbal", pois "é no acontecimento que se localizarão as fontes fundamentais produtoras da linguagem, dos sujeitos e do próprio universo discursivo".

O que se pode depreender da noção de discurso construída pelo autor é o fato de que o discurso não é "um mero acidente de uso da expressão verbal"; ao contrário, se constitui em um acontecimento que se dá na interação verbal construído pelas escolhas lingüísticas feitas pelos interlocutores e as "condições de produção" próprias de cada situação. Um acontecimento sócio-histórico, portanto.

Brandão (2000), ao tratar da noção de discurso, vai defini-lo como "toda atividade comunicativa, produtora de sentidos, ou melhor, de efeitos de sentidos entre interlocutores (sujeitos situados social e historicamente) nas suas relações interacionais”. Em outro texto (BRANDÃO, 1994, p. 11-27), a autora vai ampliar sua noção de discurso/linguagem, conceituando-o como um modo de produção social que não é neutro (tendo em vista sua intencionalidade), nem natural, "por isso o lugar privilegiado de manifestação da ideologia".

Considerando que a ideologia pode ser entendida tanto em sentido amplo, quanto em sentido restrito, sua presença nos discursos é abordada diferentemente em cada situação. Em sentido amplo, é definida como "visão de mundo" de uma dada comunidade social em um dado momento histórico, 
De uma outra perspectiva, o discurso é feito de sentido construído em um processo de interação verbal. Como diz Possenti (1988, p. 201-2), é "[...] um acontecimento, ou seja, não é previsível, nem necessário. Não é da ordem da estrutura, mas da materialidade, é um fato que acontece." Para o autor, em análise do discurso, a questão semântica deve ser compreendida como efeito de sentido tendo em vista que os enunciados acontecem em determinadas condições de enunciação ${ }^{71}$ Dessa maneira, para a análise do discurso, o contexto histórico-social é fundamental na construção do sentido.

Nesse sentido, todos os discursos são ideológicos e a ideologia é entendida "como algo inerente ao signo em geral". Em sentido restrito, é ligada à tradição marxista, sendo entendida como o mecanismo que conduz ao escamoteamento da realidade social pelo apagamento das contradições que lhe são próprias. Nesse sentido, temos a existência de um discurso ideológico que lança mão de várias estratégias para legitimar o poder de uma classe e/ou grupo social.

Para a autora, essas duas noções não se excluem se partirmos da idéia de que a ideologia, enquanto "visão de mundo", constitui-se em "uma forma legítima, verdadeira de pensar esse mundo", que pode, entretanto, ser incompatível com a realidade, ou seja, "os modos de organização dos dados fornecidos pela ideologia podem ser autônomos, imaginários, fictícios em relação aos modos de organização da realidade".

Essa incompatibilidade pode ser vivida inconscientemente, porém pode também ser produzida intencionalmente. É nesse ponto que as duas concepções de ideologia se encontram. Para Brandão, isso pode ocorrer com os discursos marcadamente institucionalizados (como, por exemplo, o discurso político, o religioso, o publicitário), onde é feito um recorte da realidade, omitindo-se, atenuando-se ou falseando-se dados - "como as contradições que subjazem às relações sociais" - de modo que a ideologia escamoteia o real.

\footnotetext{
${ }^{71}$ Enunciação aqui é entendida "... como um ato histórico e social. Portanto, não é independente de outras enunciações. [...] Uma enunciação não ocorre no vazio, mas em posições enunciativas prévias aos atos singulares de enunciação e são relativamente estáveis, embora historicamente mutáveis." Possenti, Sírio. Sobre a leitura: o que diz a Análise do Discurso?. In: Marinho, Marildes (Org.). Ler e Navegar-Espaços e Percursos da leitura. Campinas-SP: Mercado de Letras: Associação de Leitura do Brasil - ALB, 200I.
} 
Possenti, como estudioso do discurso e da AD, tem evidenciado em seus artigos a sua posição em relação à noção de discurso. Em Possenti (1988), o autor vai se referir a essa questão, em vários momentos, dos quais selecionamos alguns:

1. Refletindo sobre Língua e Discurso (1988, p. 47 a 64), coloca que o discurso deve ser entendido "como colocação em funcionamento de recursos expressivos de uma língua com certa finalidade, atividade que sempre se dá numa instância concreta e entre um locutor e um alocutário" (p. 49);

2. No mesmo artigo, vai considerar que o discurso "deve ser tratado como um acontecimento, isto é não apenas como virtualidade previsível por certa combinação de elementos segundo regras sintáticas conhecidas" (p. 61);

3. Ao pensar sobre a questão Da indeterminação à sobredeterminação (p. 201 a 212), define o discurso, conforme já referido, como "um acontecimento, ou seja, não é previsível, nem necessário. Não é da ordem da estrutura, mas da materialidade, é um fato que acontece." Para o autor, em análise do discurso, a questão semântica deve ser compreendida como efeito de sentido tendo em vista que os enunciados acontecem em determinadas condições de enunciação.

É possível, portanto, afirmar que, em AD, o contexto histórico-social é um dos aspectos determinantes na construção do sentido, sendo importante ressaltar que - sempre fundamentados na teoria que defendem - os estudiosos realizam escolhas lingüísticas diferenciadas para expressar as noções que envolvem cada enunciação, como momento histórico-social único. Entretanto, a incompletude, que é característica do movimento histórico e social, faz avançarem os estudos e as buscas teóricas, evidenciando outros desdobramentos das noções já existentes. É o que acontece com o discurso. $O$ avanço nas reflexões sobre o assunto mostra hoje (não tão atual assim: Pêcheux já tratou da questão) que não dá para falarmos em discurso sem tratarmos de outro conceito tão ou mais relevante que é o interdiscurso. Esse é um dos assuntos tratados no capítulo seguinte. 


\section{Comparamento}

Os rios recebem, no seu percurso, pedaços de pau, folhas secas, penas de urubu E demais trombolhos. Seria como o percurso de uma palavra antes de chegar ao poema.

As palavras, na viagem para o poema, recebem nossas torpezas, nossas demências, nossas vaidades.

E demais escorralhas.

As palavras se sujam de nós na viagem. Mas desembarcam no poema escorreitas: como que filtradas

E livres das tripas do nosso espírito.

(BARROS, Manoel. Ensaios Fotográficos. 2000, p. 21.) 


\section{CAPÍTULO IV}

\section{O FUNCIONAMENTO DO DISCURSO}

\subsection{DO DISCURSO AO INTERDISCURSO}

Tratar da noção de interdiscurso - em um trabalho que se pretende de base enunciativa - sem considerar as diferentes concepções elaboradas pelos estudiosos do assunto, seria ignorar a pluralidade de idéias, ignorar a própria noção do Outro no plano discursivo, ignorar o caráter sócio - histórico da própria linguagem. Diante disso, e considerando que utilizaremos essa noção na análise lingüísticodiscursiva que pretendemos realizar, procuramos abordar neste tópico as idéias sobre interdiscurso defendidas por alguns estudiosos, quais sejam, aqueles aos quais tivemos a oportunidade de estudar até este momento.

Em um movimento contínuo de reelaboração e/ou reconfiguração conceitual, o interdiscurso se apresenta sempre em relação com outras noções teóricas, melhor dizendo, sempre articulado às reflexões sobre língua, sujeito, discurso, história e ideologia. Considerado um dos conceitos fundamentais da $A D$ de linha francesa, possibilita que esta se distinga de outras abordagens teóricas ditas discursivas e de outros campos do saber.

Possenti (2003, p. 233) observa que - apresentado sob diversos nomes: polifonia, dialogismo, heterogeneidade, intertextualidade (cada um com algum ponto especifico) "o interdiscurso reina soberano há algum tempo". Entretanto, essa 'popularidade' não lhe confere o estatuto de noção pronta, definitiva, que não precisa mais ser debatida. Ao contrário, já que, conforme afirma Possenti, no campo da $A D$, não há questões vencidas, "sempre haveria o que dizer sobre o interdiscurso".

E um dos estudiosos que primeiro disse foi Pêcheux (1997, p. 162), definindo-o como o "o todo complexo com dominante das formações discursivas". Ao situar o papel da ideologia no contexto em que aborda a questão da forma-sujeito do discurso, o autor (p. 160), coloca: 
É a ideologia que fornece as evidências pelas quais "todo mundo sabe" o que é um soldado, um operário, um patrão, uma fábrica, uma greve, etc., evidências que fazem com que uma palavra ou enunciado "queiram dizer o que realmente dizem" e que mascaram, assim, sob a "transparência da linguagem", aquilo que chamaremos o caráter material do sentido das palavras e dos enunciados ${ }^{72}$.

O caráter material do sentido, segundo Pêcheux, constitui-se na dependência do "todo complexo das formações ideológicas", sendo que essa dependência se explica por meio de duas teses73. A primeira delas consiste em que as palavras, expressões, proposições, etc., mudam de sentido segundo as posições sustentadas por aqueles que as empregam (p. 160), adquirindo seu sentido em referência às formações ideológicas nas quais tais posições se inscrevem74. A segunda tese é assim definida pelo autor (1997ª, p. 162):

[...] toda formação discursiva dissimula, pela transparência do sentido que nela se constitui, sua dependência com respeito ao 'todo complexo com dominante' das formações discursivas, intrincado no complexo das formações ideológicas.

Nesse ponto de sua reflexão, Pêcheux define o "todo complexo com dominante" das formações discursivas como interdiscurso, esclarecendo que este é submetido à lei de desigualdade-contradição-subordinação que caracteriza o complexo das formações ideológicas. Nessas condições, é que toda formação discursiva dissimula, na ilusão de transparência do sentido que nela se forma, a objetividade material contraditória do interdiscurso que corresponde ao fato de que algo fala antes, em outro lugar, independentemente, sob o complexo das formações ideológicas.

O autor conclui esse ponto de discussão observando que o interdiscurso imbricado no complexo das formações ideológicas possibilita o funcionamento da Ideologia em geral como interpelação dos indivíduos em sujeitos de seu discurso.

\footnotetext{
${ }^{72}$ Os grifos são do autor.

${ }^{73} \mathrm{O}$ detalhamento, de forma mais ampla - dessas duas teses e outras discussões importantes está no livro de Pêcheux Semântica e Discurso - uma crítica à afirmação do óbvio. 3. ed. CampinasSP: Editora da UNICAMP, 1997, Capítulo III, item A forma-sujeito do discurso, p.159-80. Nosso objetivo aqui é evidenciar a posição do estudioso francês sobre a noção de interdiscurso e intradiscurso.

${ }^{74}$ Os grifos são do autor.
} 
Nesse contexto, o autor discute o pré-construído e a articulação como dois elementos que constituem o interdiscurso e assim determinam o sujeito, impondo/dissimulando-Ihe o assujeitamento através de uma aparente autonomia. $O$ pré-construído "corresponde ao 'sempre-já-aí' da interpelação ideológica que fornece-impõe a 'realidade' e seu 'sentido' sob a forma de universalidade ('mundo das coisas')". A articulação compreende "aquilo que determina a dominação da forma-sujeito" e forma o sujeito "em sua relação com o sentido" (p.164).

Deriva daí a noção de intradiscurso, apresentada por Pêcheux como "o fio do discurso" do sujeito falante, que corresponde ao "efeito do interdiscurso sobre si mesmo" (p. 167), uma interioridade determinada "do exterior". O intradiscurso marca, portanto, a relação que o sujeito tem consigo mesmo, numa interligação com aquilo que disse antes e com o que dirá no futuro.

Já Courtine (1981, p. 49), em sua pesquisa, ao tratar da descrição do interdiscurso de uma formação discursiva, coloca que ele deve ser pensado

[...] como um processo de reconfiguração incessante no qual o saber de uma FD é levado, em função das posições ideológicas que essa FD representa numa conjuntura determinada, a incorporar elementos pré-construídos produzidos em seu próprio exterior, a produzir sua redefinição e seu retorno, a suscitar igualmente a lembrança de seus próprios elementos, a organizar sua repetição, mas também a provocar eventualmente seu desaparecimento, seu esquecimento ou mesmo sua denegação.

Nesse aspecto, o interdiscurso é considerado como o que regula 0 deslocamento das fronteiras de uma FD, em um processo que tanto pode organizar repetições, como pode suscitar desaparecimento, esquecimento ou mesmo a denegação daqueles dizeres que o tornam possível.

Esse conceito é abordado por Brandão (1994, p. 71-81), que, pautando-se em teóricos como Courtine e Marandin, Maingueneau e Foucault, trata da relação discurso - interdiscurso, memória discursiva e efeitos de memória, entre outros... Inicia sua reflexão sobre a noção de interdiscursividade pelo discurso, pontuando que estudá-lo a partir do princípio dialógico implica evidenciar aquela que é sua característica fundamental: a heterogeneidade. "Heterogeneidade que liga de 
maneira constitutiva o Mesmo do discurso com o seu Outro ou, em outros termos, que permite a inscrição no discurso daquilo que se costuma chamar seu 'exterior'".

A autora ressalta a avaliação crítica do campo da $A D$ feita por Courtine e Marandin (1981) em que estes questionam trabalhos que acabam escamoteando 0 caráter heterogêneo do discurso, já que procuram apreender o idêntico através de procedimentos de homogeneização. Como solução frente a essa homogeneização, a $A D$ deve realizar um trabalho que possibilite 0 aflorar das contradições; que evidencie o diferente constitutivo de todo discurso; que não exclua a noção de heterogeneidade.

Esse tratamento dado ao discurso vai alterar o conceito de FD considerado nuclear para a $A D$. Definida, inadequadamente por alguns, como constituída de "uma única linguagem para todos", a FD não deve ser concebida como um bloco compacto e homogêneo que se opõe a outras FDs, mas como uma realidade heterogênea por si mesma que apresenta um fechamento bastante instável e um limite tênue entre seu "interior" e seu "exterior" uma vez que, conforme Brandão ( $p$. 72), "ela confina com várias outras FDs e as fronteiras entre elas se deslocam conforme os embates da luta ideológica. É assim que se pode afirmar que uma FD é atravessada por várias FDs e, conseqüentemente, que toda FD é definida a partir de seu interdiscurso."

Com relação à questão da heterogeneidade, temos também os trabalhos desenvolvidos pela lingüista J.Authier-Revuz (2004, p.11.), sobre a heterogeneidade, que têm sido relevantes para a AD. Numa perspectiva interdisciplinar, Authier influenciada pela concepção dialógica de Bakhtin e pela psicanálise - defende, em suas reflexões, a linguagem como constitutivamente heterogênea. Propõe dois tipos de heterogeneidade: a heterogeneidade mostrada e a heterogeneidade constitutiva que, através do princípio da alteridade, mostram como o discurso se relaciona com o seu "exterior". Nessa relação tem papel fundamental a memória discursiva, que vai possibilitar, na tessitura que faz emergir o interdiscurso de uma FD, a evidência da concordância, da rejeição ou da transformação de enunciados de outras FDs historicamente relacionadas.

$\mathrm{Na}$ heterogeneidade constitutiva não é possível se definir fronteiras nítidas entre o dizer do locutor e o dizer do outro, por uma abordagem lingüística stricto sensu. Ela é da ordem do interdiscurso e, amparada pelos pressupostos 
psicanalíticos, da ordem do inconsciente. A pesquisadora francesa coloca essa heterogeneidade como uma ancoragem necessária para a outra forma de heterogeneidade: a mostrada (marcada e não-marcada), e completa que, nessa perspectiva lingüística, busca apoio para essa ancoragem em "duas abordagens não-lingüísticas da heterogeneidade constitutiva da fala e do discurso: o dialogismo do círculo de Bakhtin e a psicanálise (através da leitura de Freud, marcada por Lacan).

A heterogeneidade mostrada evidencia, na própria superfície discursiva, as marcas da presença do outro, ou seja, a alteridade se expressa no discurso, podendo ser restabelecida explicitamente através da análise.

Ela se constitui de duas formas:

1. mostrada marcada em que a voz do outro é visível na materialidade discursiva pelas formas marcadas, como as do discurso relatado (discurso direto e indireto), as formas utilizadas pelo locutor para inscrever as palavras do outro no seu discurso (uso das aspas, do itálico entre outras);

2. mostrada não-marcada são aquelas em que o dizer do outro não é marcado lingüisticamente, como no caso do discurso indireto livre, da ironia, da pressuposição, entre outros.

Maingueneau (2005, p.33) é outro estudioso que trata da questão para explicitar que é da perspectiva da heterogeneidade constitutiva "que amarra, em uma relação inextricável, o Mesmo do discurso e seu Outro" que postula o primado do interdiscurso sobre o discurso.

Segundo o autor: "[...] a unidade de análise pertinente não é o discurso, mas um espaço de trocas entre vários discursos convenientemente escolhidos" (p. 2). Para Brandão (1994, p. 72), essa primazia pode ser entendida sob dois aspectos:

1. de uma forma geral, o estudo da especificidade de um discurso se dá na relação com outros discursos;

2. de uma forma específica, o interdiscurso torna-se o espaço de regularidade pertinente, que faz dos diversos discursos apenas seus componentes. Esses discursos se constituiriam na relação interdiscursiva e não, inicialmente, de forma independente uns dos outros, para depois serem colocados em relação. 
Maingueneau se reporta à antologia publicada por Todorov sobre o "princípio dialógico" de Bakhtin, isto é, o caráter constitutivo da interação enunciativa e afirma que "essa visão da atividade 'linguageira' converge amplamente" com as suas preocupações sobre a interdiscursividade. Segundo Maingueneau (2005, p. 35), para o teórico russo: "[...] o discurso reencontra o discurso do outro em todos os caminhos que levam a seu objeto, e um não pode não entrar em relação viva e intensa com o outro".

Além das pesquisas do "círculo de Bakhtin" que reforçam a hipótese de Maingueneau sobre o primado do interdiscurso, são citados outros estudos que convergem com as preocupações do autor. No domínio da literatura, estão os trabalhos de G. Genette: Introdução ao arquitexto, no qual o objeto da poética não é o texto singular, mas as relações que um texto institui com outros textos: a "arquitextualidade". Ainda deste mesmo autor, Maingueneau cita a obra Palimpsestes, que trata da "hipertextualidade", ou seja, da relação entre um texto $B$ (hipertexto) e um texto anterior A (hipotexto).

Podemos depreender então, que a hipótese levantada por Maingueneau é a de que a interdiscursividade antecede à discursividade, ou seja, tem a primazia como objeto de análise, pois é aí que a relação Eu x Outro se constitui.

$\mathrm{Na}$ especificação do interdiscurso, Maingueneau (2005, p. 35) coloca que "[...] é necessário afinar este termo muito vago para nosso propósito e substituí-lo por uma tríade: universo discursivo, campo discursivo, espaço discursivo." A conceituação de universo, campo e espaço discursivos surge do interesse do pesquisador francês em esboçar com bastante precisão a dinâmica dessa relação Eu x Outro no interior de uma Formação discursiva (PICCARDI, 2005, p. 38).

Universo discursivo corresponde "[...] ao conjunto de formações discursivas de todos os tipos que interagem numa conjuntura dada" (MAINGUENEAU, 2005, p. 35). Constitui um conjunto acabado, ainda que não possa ser apreendido em sua globalidade. É de pouco interesse para o analista, sendo importante apenas para definir o espaço a partir do qual serão construídos domínios susceptíveis de serem estudados, os "campos discursivos".

Campo discursivo compreende "[...] um conjunto de formações discursivas que se encontram em concorrência, delimitam-se reciprocamente em uma região 
determinada do universo discursivo" (MAINGUENEAU, 2005, p. 35). Concorrência, nesse caso, deve ser compreendida da forma mais abrangente, incluindo tanto 0 confronto aberto, quanto a aliança, a neutralidade aparente, etc., entre discursos que possuem uma mesma função social, mas divergem sobre a maneira de preenchê-la. Pode tratar, por exemplo, do campo político, filosófico, dramatúrgico, gramatical, etc. Esse recorte em "campos" não define zonas isoladas; é apenas uma abstração necessária que deve permitir abrir múltiplas redes de trocas.

Espaços discursivos são os "[...] subconjuntos de formações discursivas que o analista julga relevante para seu propósito colocar em relação." (MAINGUENEAU, 2005 , p. 37). Esses subconjuntos só podem ser o resultado de uma hipótese fundamentada em um conhecimento dos textos e um saber histórico que, no percurso da pesquisa, pode se confirmar ou não.

O autor acrescenta que reconhecer esse tipo de primazia do interdiscurso é instigar a construir um sistema através do qual a definição de uma rede semântica circunscrita na especificidade de um discurso coincide com a definição das relações desse discurso com seu Outro. Considerando que um discurso se reporta sempre a outros discursos, suas condições de possibilidade semântica se dariam em um espaço de trocas, mas nunca enquanto identidade fechada.

Maingueneau (2005, p.38) coloca que esse ponto de vista se contrapõe aquele defendido espontaneamente pelos enunciadores discursivos, que não aceitam esse descentramento radical e reivindicam, de fato, a autonomia de seu discurso. E completa (p. 38)

[...] uma concepção primária do 'fechamento' estrutural inscreve-se no prolongamento de uma corrente da análise do discurso que busca repensar as relações do Mesmo e do Outro tais como se desenhavam nos anos 60.

Repensar essa equivalência entre o "exterior" do discurso e o interdiscurso se faz necessário para marcar a presença do interdiscurso "no próprio coração do intradiscurso", ou seja, "inscrevendo o Outro no Mesmo" (Brandão, 1994 p. 74). O caráter dialógico que caracteriza todo enunciado do discurso integra sempre a interação dos discursos com o funcionamento intradiscursivo e não está circunscrito 
unicamente aos enunciados que apresentam citações, alusões, etc., nem ao Outro, que no espaço discursivo, não é reduzível a uma figura de interlocutor. Segundo Maingueneau (2005, p. 39):

No espaço discursivo, o Outro não é nem um fragmento localizável, uma citação, nem uma entidade exterior; não é necessário que seja localizável por alguma ruptura visível da compacidade do discurso. Encontra-se na raiz de um Mesmo sempre já descentrado em relação a si próprio, que não é em momento algum passível de ser considerado sob a figura de uma plenitude autônoma. É o que faz sistematicamente falta a um discurso e lhe permite fechar-se em um todo. É aquela parte de sentido que foi necessário que o discurso sacrificasse para constituir sua identidade.

O pesquisador francês (p.21), ao defender o primado do interdiscurso sobre o discurso, postula, como referimos anteriormente, que a unidade de análise pertinente se constitui em um espaço de trocas entre discursos convenientemente escolhidos. Considerando o dialogismo, de acordo com Bakhtin, como o princípio constitutivo da linguagem, podemos afirmar que o discurso se constitui das/nas muitas vozes já ditas. Para Maingueneau (1998, p. 86), é na relação, muitas vezes conflituosa, com o Outro que o interdiscurso se constitui como "o conjunto das unidades discursivas com as quais ele entra em relação".

Orlandi (2000, p. 31-55) por sua vez vai abordar a questão do interdiscurso como memória discursiva. Para a autora, a memória, quando pensada em relação ao discurso, é tratada como interdiscurso, entendido "como aquilo que fala antes, em outro lugar, independentemente". É a chamada memória discursiva: "o saber discursivo que torna possível todo dizer e que retorna sob a forma do pré-construído, o já-dito que está na base do dizível, sustentando cada tomada da palavra" (p. 31). Exemplificando os aspectos teóricos levantados em um texto de uma faixa sobre a eleição na Unicamp, que tinha os seguintes dizeres: VOTE SEM MEDO, a autora explicita as questões contextualizando o papel e a posição do sujeito e do dizer. Tudo o que já foi dito a respeito de eleições (voto e eleitores), bem como os dizeres políticos que, em diferentes momentos/por diferentes candidatos, compreenderam os sentidos da política universitária estão, de alguma maneira significando naquela faixa. 
Dentro da concepção da $A D$, tanto o dizer como as palavras não são "nossos", eles significam historicamente e pela língua. O que é dito em outro lugar e em outro momento também significa em nossas palavras. Todo sujeito acredita que sabe o que diz, mas, na verdade, como observa Orlandi, não tem controle sobre a maneira pela qual os sentidos se constituem nele. $O$ já-dito que se encontra na base do dizer, é imprescindível para que possamos entender o funcionamento do discurso e sua relação com os sujeitos e a ideologia. Pode-se dizer, portanto, que existe uma relação entre o já-dito e o que se está dizendo, que corresponde à mesma relação que existe entre o interdiscurso (constituição do sentido) e o intradiscurso. (formulação do sentido).

Segundo a autora, Courtine (1984) vai assim explicitar a diferença entre:

1. Interdiscurso $=$ pode ser representado por um eixo vertical, no qual teríamos todos os já-ditos e esquecidos que, em seu conjunto, representa o dizível.

2. Intradiscurso = pode ser representado por um eixo horizontal, ou eixo da formulação, que corresponde àquilo que estamos dizendo naquele momento, naquelas condições específicas.

Dessa maneira, o intradiscurso que corresponde à formulação é determinado pelo interdiscurso também chamado de constituição, afinal, só conseguimos dizer a partir do dizível. Todo discurso (dizer) se constrói na interrelação entre os eixos da memória e da atualidade. Da mesma forma, o interdiscurso, a historicidade é o que vai estabelecer quais aspectos da situação, das condições de produção é fundamental para a discursividade.

Em seguida, a autora alerta para a necessidade de termos clara a diferença entre interdiscurso e intertexto. O primeiro é definido por ela como "o conjunto de formulações feitas e já esquecidas que determinam o que dizemos. É necessário que aquele já-dito em outro momento e em outras circunstâncias por um determinado sujeito, seja esquecido, passe ao anonimato para que venha a fazer sentido em 'minhas' palavras." Já o intertexto se constitui na relação com outros textos, não fazendo parte da estrutura dessa intertextualidade, o esquecimento, como o faz no interdiscurso.

A AD, para a autora $(2000$, p. 34$)$, propõe uma leitura que leve em conta esses efeitos. Assim: 
[...] essa nova prática de leitura, que é discursiva, consiste em considerar o que é dito em um discurso e o que é dito em outro, o que é dito de um modo e o que é dito de outro, procurando escutar o não-dito naquilo que é dito, (...) Isso que (...) só uma parte do dizível é acessível ao sujeito, pois mesmo o que ele não diz (e que muitas vezes ele desconhece) significa em suas palavras.

Ainda dentro desse contexto, Orlandi vai refletir sobre os dois esquecimentos postulados por Pêcheux e já referidos neste trabalho. O esquecimento número um é aquele pelo qual temos a ilusão de sermos a origem do nosso dizer, mas, na verdade, o que fazemos é retomarmos sentidos preexistentes. Como observa a autora, embora os sentidos se representem como originando-se em nós, na realidade, são definidos pelo modo como nos inscrevemos na língua e na história. É, em razão disso, que eles significam e não porque assim o desejamos.

O esquecimento número dois é da ordem da enunciação: toda vez que dizemos o fazemos através de escolhas e no percurso de nosso dizer formam-se famílias parafrásticas que evidenciam que o dizer poderia ser outro. No caso do dizer da faixa (aludida à p. 101), poderíamos, ao invés de "sem medo", usar "com coragem" ou "consciente". Entretanto, muitas vezes retomamos o nosso dizer, realizamos substituições para elucidar melhor o que dizemos, sendo este, portanto, um esquecimento parcial ou semi-consciente. É o esquecimento enunciativo que mostra que a sintaxe tem um significado distinto: o modo de dizer é constitutivo dos sentidos.

A autora ressalta que o esquecimento é parte da constituição dos sujeitos e dos sentidos. Dessa forma, as ilusões não se configuram como "defeitos", pelo contrário, são necessárias para que a linguagem funcione nos sujeitos e na construção dos sentidos. "Os sujeitos 'esquecem' que já foi dito - e este não é um esquecimento voluntário - para, ao se identificarem com o que dizem constituíremse em sujeitos" (ORLANDI, 2000, p. 36) É dessa maneira que as palavras ganham sentido e os sujeitos se significam: resgatando palavras que já existem e empregando-as como se fossem suas, os sujeitos e, conseqüentemente, os sentidos estão sempre em movimento, significando de muitas e várias maneiras.

Dessa maneira, a construção do discurso se faz na tensão contínua entre o mesmo e o diferente. "E é nesse jogo entre paráfrase e polissemia, entre o mesmo e 
o diferente, entre o já-dito e o a dizer que os sujeitos e os sentidos se movimentam, fazem seus percursos, (se) significam" (p. 36).

Fiorin (2006, p. 161-193) aborda a noção de interdiscurso em Bakhtin em seu artigo Interdiscursividade e intertextualidade. Partindo de dois objetivos verificar se, sob outro nome, a questão do interdiscurso está presente na obra de Bakhtin e examinar se é possível distinguir, com base nas idéias bakhtinianas, interdiscursividade e intertextualidade - o autor inicialmente traça um histórico do aparecimento do termo intertextualidade afirmando que essa palavra foi uma das primeiras atribuídas a Bakhtin que ganhou prestígio no Ocidente, por meio da obra de Julia Kristeva. Segundo o autor, a palavra intertextualidade obteve cidadania acadêmica antes de o termo dialogismo alcançar notoriedade. Ressaltou ainda a contribuição de Roland Barthes em relação ao termo e finalizou pontuando que, ao longo do tempo, esse termo passou a ser utilizado de maneira frouxa.

Em seguida, centra-se na noção de interdiscurso e intertextualidade em Bakhtin fundamentando-se em toda a obra do teórico russo. Afirma inicialmente que a questão do interdiscurso, em Bakhtin, apresenta-se sob o nome de dialogismo, mas ressalta que é preciso refletir mais detidamente sobre essa noção. É preciso, em primeiro lugar, afastar duas leituras não procedentes, mas recorrentes sobre esse conceito; aquela que preceitua dialogismo como equivalente a diálogo no sentido de interação face a face e a outra que afirma que há dois tipos de dialogismo: o dialogismo entre interlocutores e o dialogismo entre discursos.

Para o pesquisador brasileiro, o dialogismo não se confunde com a interação face a face, por ser uma forma composicional em que "ocorrem relações dialógicas que se dão em todos os enunciados no processo de comunicação, tenham eles a dimensão que tiverem" (p. 166). O outro aspecto é que só há dialogismo entre discursos, pois o interlocutor só existe enquanto discurso. Portanto, não existe dialogismo entre interlocutores, o que há é "um embate entre dois discursos: o do locutor e o do interlocutor, o que significa que o dialogismo se dá sempre entre discursos" (p. 166).

Considerando o que efetivamente é dialogismo em Bakhtin, Fiorin destaca dois sentidos que lhe interessam para a concretização dos objetivos traçados na discussão sobre a interdiscursividade e intertextualidade. Primeiramente, concebe o dialogismo como o modo de funcionamento real da linguagem e, portanto, seu 
princípio constitutivo. Em segundo lugar, dialogismo é uma forma particular de composição do discurso ${ }^{75}$.

Pontuando que os homens não têm acesso direto à realidade, tendo em vista que nossa relação com essa realidade é sempre mediada pela linguagem e destacando a afirmação de Bakhtin de que não é possível ter-se a experiência do dado puro, o autor mostra que o real se apresenta para nós semioticamente em uma evidência de que o nosso discurso não faz uma relação direta com as coisas e sim com outros discursos. "Essa relação entre os discursos é o dialogismo". Dessa maneira, se não temos relação com as coisas e sim com os discursos que thes dão sentido, "dialogismo é o modo de funcionamento real da linguagem" (p. 167).

No entender do autor, Bakhtin não nega a existência do sistema da língua, já que "por trás de todo texto, encontra-se o sistema da língua" (Bakhtin, 1992, p. 331), o qual, para o teórico russo, é necessário para o estudo das unidades da língua, mas que, no entanto, não dá conta do modo de funcionamento real da linguagem. Em razão disso, Bakhtin propõe uma outra disciplina que nomeia de metalingüística $^{76}$ (p. 320). Essa disciplina tem por objeto "o exame das relações dialógicas entre os enunciados, seu modo de constituição real” (Fiorin, 2006, p. 168).

Pautado no texto de Bakhtin O Problema do texto ${ }^{77}$, Fiorin vai tratar do enunciado e das unidades da língua, mostrando as características próprias destas e daquele e, conseqüentemente, as diferenças que se evidenciam. Dentre essas características, destacamos aquela que evidencia que as unidades da língua compreendem as palavras e as orações, enquanto os enunciados são as unidades

\footnotetext{
${ }^{75}$ Em nota, Fiorin destaca um terceiro sentido que registramos aqui: visto de uma forma mais geral, dialogismo "é o princípio de constituição dos seres humanos; é o modo de agir e de estar no mundo" (FIORIN, 2006, p.192).

${ }^{76}$ Fiorin chama esta disciplina de Translingüística e justifica sua escolha, à maneira dos franceses, em razão dos valores semânticos que cercam a palavra metalingüística. "Esse problema de denominação é uma prova da correção das teses bakhtinianas sobre o problema da distinção entre as unidades potenciais do sistema (objeto da Lingüística) e as unidades reais de comunicação (objeto da translingüística). Do ponto de vista do sistema, meta (prefixo grego) e trans (prefixo latino) são equivalentes: no entanto, eles são completamente distintos no funcionamento discursivo". O autor coloca que o objetivo de Bakhtin era instituir uma ciência que fosse além da Lingüística, que pudesse analisar o funcionamento real da linguagem e não só o sistema virtual que permite esse funcionamento (p.162).

${ }^{77}$ Esse texto faz parte da Obra Estética da criação verbal que tem hoje, no Brasil, duas traduções. Na tradução do francês, feita por Maria Ermantina Galvão G. Pereira, o referido texto se encontra às páginas 327- 58 e na tradução do russo, elaborada por Paulo Bezerra, às páginas 307- 35. A obra utilizada por Fiorin é a tradução do francês e datada de 1992.
} 
reais de comunicação. "As primeiras são repetíveis, os segundos, irrepetíveis, são sempre acontecimentos únicos" (p.168).

Fiorin observa que não é a dimensão que define o que é um enunciado, já que este pode ser tanto uma resposta de uma palavra quanto um romance de vários volumes. O que delimita a fronteira do enunciado "é a alternância dos sujeitos falantes. Isso significa que o enunciado é uma réplica de um diálogo que se estabelece entre todos eles" (p. 168). Dessa forma, o dialogismo é constitutivo do enunciado e este não tem existência fora daquele. "A relação dialógica é uma relação (de sentido) que se estabelece entre enunciados na comunicação verbal” ( $p$. 169).

Neste sentido, vejamos o que diz Bakhtin (2006, p. 296-297):

Todo enunciado concreto é um elo na cadeia da comunicação discursiva de um determinado campo. Os próprios limites do enunciado são determinados pela alternância dos sujeitos do discurso. Os enunciados não são indiferentes entre si nem se bastam cada um a si mesmos; uns conhecem os outros e se refletem mutuamente uns nos outros. Esses reflexos mútuos Ihes determinam o caráter. Cada enunciado é pleno de ecos e ressonâncias de outros enunciados com os quais está ligado pela identidade da esfera de comunicação discursiva. Cada enunciado deve ser visto antes de tudo como uma resposta aos enunciados precedentes de um determinado campo (aqui concebemos a palavra "resposta" no sentido mais amplo): ela os rejeita, confirma, completa, baseia-se neles, subentende-os como conhecidos, de certo modo os leva em conta. Porque o enunciado ocupa uma posição definida em uma dada esfera da comunicação, em uma dada questão, em um dado assunto, etc. É impossível alguém definir sua posição sem correlacioná-la com outras posições.

As várias características do enunciado e das unidades da língua são pontuadas por Fiorin com exemplificações de vários textos, bem como a distinção entre texto e enunciado. Diante das considerações: se um texto tem um autor, é irrepetível e só ganha sentido na relação dialógica, não é então sinônimo de enunciado? o autor afirma que é preciso ler cuidadosamente o que o teórico russo coloca acerca do assunto ao longo de suas obras ${ }^{78}$. Nesse sentido,vejamos o que afirma Bakhtin (1992, p. 330-351):

${ }^{78} \mathrm{O}$ leitor encontrará, principalmente, na obra Estética da criação verbal maiores informações e aprofundamento em relação às idéias de Bakhtin sobre enunciado, texto e gêneros do discurso. 
O texto enquanto enunciado. (...) Dois fatores determinam um texto e o tornam um enunciado: seu projeto (a intenção) e a execução desse projeto. (...) Fora dessa relação (a relação dialógica), o enunciado não tem realidade (a não ser como texto).

Como observa Fiorin (2006, p. 180), a partir do momento que o texto se torna um enunciado, ele é distinto deste e

[...] se o texto é distinto do enunciado e este é um todo de sentido marcado pelo acabamento (a obra), dado pela possibilidade de admitir uma réplica, cuja natureza específica é dialógica, o texto é a manifestação do enunciado, que é uma 'postura de sentido'.

O autor conclui afirmando que: se Bakhtin estabelece uma diferença entre texto e enunciado; se o enunciado pode ser aproximado ao que se compreende por interdiscurso - tendo em vista que se constitui nas relações dialógicas, enquanto o texto e a manifestação desse enunciado - é possível estabelecer uma diferença entre interdiscursividade e intertextualidade: "aquela é qualquer relação dialógica entre enunciados; esta é um tipo particular de interdiscursividade, aquela em que se encontram num texto duas materialidades textuais ${ }^{79}$ distintas"(p. 191).

A historicidade do discurso, em Bakhtin, é apreendida no movimento lingüístico da constituição da noção de dialogismo. Segundo Fiorin (p. 191-192): "É na relação com o discurso do Outro, que se apreende a história que perpassa 0 discurso. (...), em Bakhtin, a História não é algo exterior ao discurso, mas interior a ele, pois o sentido é histórico".

\section{2 $O$ ato de enunciação e os modos da subjetividade enunciativa em Maingueneau}

Em sua proposta que denomina de semântica "global”, Maingueneau (2005, p. 79-102) explicita que essa é uma semântica que não compreende o discurso

\footnotetext{
${ }^{79}$ Para o autor, materialidade textual compreende um texto em sentido estrito ou um conjunto de fatos lingüísticos, que configura um estilo, um jargão, uma variante lingüística, etc. (p.191).
} 
dando privilégio a este ou aquele "plano", mas integrando todos eles na ordem do enunciado e na ordem da enunciação.

Diferentemente de uma abordagem que destaca o monopólio das análises lexicológicas e os projetos, bem fundamentados, em relação ao texto filosófico, para o autor, não há ordem de importância entre os planos semânticos.

Para Maingueneau (2005, p. 81) "sua única finalidade é ilustrar a variedade das dimensões concernidas pela perspectiva de uma semântica global, e nada impede de isolar outras ou de repartir diferentemente as divisões propostas." Considerando o que diz o autor, selecionamos os aspectos que julgamos pertinentes para a análise do corpus deste trabalho.

\subsubsection{O estatuto do enunciador e do destinatário}

Segundo Maingueneau (p. 91), os diversos modos da subjetividade enunciativa dependem igualmente da competência discursiva. Cada discurso define o estatuto que o enunciador deve conferir-se e conferir a seu destinatário para legitimar o seu dizer.

\subsubsection{A dêixis enunciativa}

O ato de enunciação supõe a instauração de uma dêixis espaço-temporal que cada discurso constrói em função de seu próprio universo. Não corresponde às datas dos locais em que os enunciados efetivos foram produzidos, mas de um espaço-tempo criado no discurso e que não coincide com a realidade biográfica dos autores.

\subsubsection{O modo de enunciação}

Um discurso não se constitui de determinado conteúdo associado a uma dêixis e a um estatuto de enunciador e de destinatário; ele é também uma "maneira de dizer" específica. É o tom do discurso, que se apóia na dupla figura do 
enunciador: sua corporalidade e seu caráter - inseparáveis um do outro. Para o autor (2005, p. 97)

[...] Se, segundo a expressão de M. de Certeau, "cada sociedade tem seu corpo", delimitado por múltiplas codificações, cada discurso também tem o seu: corpo textual que não se dá jamais a ver, mas presente por toda a parte, disseminado em todos os planos discursivos.

A metáfora do cotidiano, entendida como uma forma de dizer, será tratada a partir do modo de enunciação.

\subsection{A METÁFORA}

O estudo da metáfora tem despertado a atenção dos estudiosos da linguagem desde a antigüidade. Entretanto, podemos dizer que uma vasta produção de estudos e pesquisas sobre a metáfora - com o surgimento de muitas teorias se deu nos últimos trinta anos ${ }^{80}$.

Quando tratamos sobre a metáfora, é comum pensarmos imediatamente no texto literário, em especial, no seu sentido poético, já que ela foi considerada, por muito tempo, como um recurso estilístico essencialmente da linguagem poética. Nessa perspectiva, sua função era/é de ornamento retórico". Mesmo para algumas das abordagens mais recentes, a metáfora não passa de um desvio de um sentido anterior ou, em outro aspecto, como sentido conotado, transformado, além de ser indesejável no discurso científico. Por outro lado, há teorias atuais que vêm propor uma ruptura com essa visão corrente da metáfora.

Uma das intervenções teóricas de maior repercussão em relação a uma nova visão do papel da metáfora na linguagem está na obra de Lakoff e Johnson, intitulada Metáforas da Vida Cotidiana, que discute a base conceitual da metáfora e sua influência na estruturação do pensamento. Para Lakoff \& Johnson (2002, p. 45), o "conceito metafórico" estrutura o pensamento e a ação humana:

${ }^{80}$ Conf. ZANOTTO, M. S. et. alli. Apresentação à edição brasileira. In: LAKOFF,G. \& JOHNSON, M. Metáforas da vida cotidiana.[coord. da tradução Mara S. Zanotto] - Campinas-SP: Mercado de Letras; São Paulo: EDUC, 2002. 
[...] a maioria das pessoas acha que pode viver perfeitamente bem sem a metáfora. Nós descobrimos, ao contrário, que a metáfora está infiltrada na vida cotidiana, não somente na linguagem, mas também no pensamento e na ação. Nosso sistema conceptual ordinário, em termos do qual não só pensamos mas também agimos, é fundamentalmente metafórico por natureza.

Para os autores, a metáfora é definida como um processo cognitivo próprio do sistema conceitual humano diferente da concepção que a estudava apenas como uma figura de linguagem. Nesse sentido, a formação dos conceitos é orgânica, já que constitui um princípio estruturante de natureza psico-fisiológica. Esses conceitos dirigem nossos pensamentos, mas não só isso, regem as nossas atividades cotidianas até nas questões mais banais, exercendo "um papel central na definição de nossa realidade cotidiana (p. 46), de nossas experiências. "Eles estruturam o que percebemos, a maneira como nos comportamos no mundo e o modo como nos relacionamos com outras pessoas" (p. 45-46).

Para exemplificar o conceito metafórico, partem do conceito de DISCUSSÃO por meio da metáfora conceptual DISCUSSÃO É GUERRA, presente em nossa vida cotidiana em um sem número de expressões, tais como:

Seus argumentos são indefensáveis.(Your claims are indefensible.)

Suas críticas foram direto ao alvo. (His criticisms were right on target.)

Destruí sua argumentação. (I demolished his argument.)

Como podemos ver, embora não exista uma batalha física ou verbal que esteja na base da estrutura de uma discussão, é assim que a concebemos em nossa cultura. Por isso, para os autores "a essência da metáfora é compreender e experienciar uma coisa em termos de outra" (p. 47-48).

Diante dessas considerações, podemos colocar que a grande importância do trabalho desses dois estudiosos está no fato de que concebem a metáfora de forma muito mais abrangente do que as abordagens anteriores, isto é, concebem-na como constitutiva da experiência humana, sendo "vista como parte da experiência cotidiana do uso da língua, que estrutura 0 pensamento $e$ a ação humana"(JOANILHO, 1995, p. 39). 
Em sua teoria, Lakoff e Johnson (2002, p. 59-76) estabelecem uma classificação dos conceitos metafóricos, agrupandos-os em três grandes classes, a saber:

1. Metáforas estruturais - são aquelas nas quais [...] um conceito é estruturado metaforicamente em termos de outro" (LAKOFF \& JOHNSON, 2002, p.59). É o caso da metáfora DISCUSSÃO É GUERRA, em que o conceito DISCUSSÃO é definido em termos do conceito GUERRA.

2. Metáforas orientacionais ou espaciais - são as metáforas que, diferentemente das primeiras, organizam todo um sistema de conceitos em relação a outro. Essas metáforas recebem esse nome porque a maioria delas tem a ver com a orientação espacial como, por exemplo: FELIZ É PARA CIMA, que possibilita expressões como "Estou me sentindo para cima hoje" (I'm feeling up today).

3. Metáforas ontológicas - essas metáforas surgem de nossa experiência com "substâncias e objetos físicos. Segundo os autores, "as experiências que vivenciamos (especialmente com o nosso corpo) fornecem uma ampla base de metáforas ontológicas, ou seja, a maneira de concebermos eventos, atividades, emoções, idéias... como entidades e substâncias." Um exemplo é a metáfora MENTE É UMA MÁQUINA da qual surge a expressão "Estou um pouco enferrujado hoje." (I'm a little rusty today.). Para Lakoff e Johnson, a personificação seria uma metáfora ontológica, já que nos possibilita compreender muitas experiências relativas a entidades não-humanas como humanas. Assim "a personificação é,pois, uma categoria geral que cobre uma enorme gama de metáforas, cada uma selecionando aspectos diferentes de uma pessoa ou modos diferentes de considerála" (p. 88). Um dos exemplos dados é a metáfora INFLAÇÃO É UM ADVERSÁRIO, que se justifica cotidianamente em expressões do tipo "A inflação roubou as minhas economias" (Inflation has robbed me of my savings.)

Os autores propõem, com sua teoria, que os conceitos metafóricos decorrem da própria experiência humana que manifesta um sistema conceptual subjacente à linguagem. 


\subsection{OS GÊNEROS DO DISCURSO}

Pode-se considerar recente, principalmente no Brasil, o interesse e as pesquisas sobre os gêneros do discurso, no meio acadêmico. Vários estudiosos têm se colocado sobre o assunto e ancorado seus estudos de acordo com suas concepções e com os próprios objetivos da pesquisa. Nesse aspecto, seria ingênuo pensar que essas diferentes pesquisas, ao tratar dos gêneros discursivos, estejam tratando do mesmo objeto teórico.

No caso brasileiro, Bakhtin surge como um dos autores mais citados por pesquisadores que defendem perspectivas teóricas próximas às do autor. $\mathrm{O}$ texto, na perspectiva bakhtiniana, é tecido polifonicamente através de "vozes" que se cruzam e estão presentes nos enunciados que se constituem no espaço discursivo entre o "eu" e o "outro", em uma relação de identidade/alteridade, em situações concretas de interação. Para Bakhtin, o uso da língua se efetiva em enunciados, orais e escritos, concretos e únicos, que emanam de sujeitos, histórica e socialmente constituídos.

O enunciado concreto é definido pelo autor como a unidade real da comunicação verbal que tem no diálogo, por sua clareza e simplicidade, a forma clássica de comunicação, já que é ele que evidencia, de forma mais direta, a alternância entre os sujeitos falantes e a possibilidade de réplica. Além da alternância entre os sujeitos falantes, temos como propriedades desse enunciado:

a) o acabamento específico do enunciado, que se constitui de três fatores que, de forma articulada, determinam, segundo Bakhtin, a possibilidade de responder:

1. o tratamento exaustivo do tema;

2. a intenção, o querer-dizer do locutor;

3. as formas típicas de estruturação do gênero do acabamento.

b) a relação do enunciado com o próprio locutor e com os interlocutores da comunicação verbal.

Essas propriedades do enunciado concreto nos remetem a um aspecto que julgamos muito importante para a nossa análise, que é a questão dos gêneros do discurso: formas, relativamente estáveis, dos enunciados que, segundo Bakhtin 
(2003, p. 261), refletem "as condições específicas e as finalidades de cada uma dessas esferas, não só por seu conteúdo (temático) e por seu estilo verbal (...) mas também, e sobretudo, por sua construção composicional." O fato de nos dirigirmos a alguém, a nossa relação com esse alguém, o intuito de dizer sobre determinado tema, leva- nos à escolha da(s) forma(s) típica(s) de dizer, ou seja, à estruturação do gênero discursivo mais pertinente ao contexto enunciativo, à esfera de atividade em que os falantes estão engajados.

Definindo os gêneros do discurso como tipos relativamente estáveis de enunciados, o teórico russo classifica-os em gêneros do discurso primário (simples, como por exemplo a réplica do diálogo cotidiano), e gêneros do discurso secundário (complexos) que se constituem em contextos de comunicação cultural mais ampla, mais complexa, principalmente na escrita: artística e/ou científica, por exemplo.

Os gêneros secundários, no seu processo de formação, incorporam e reelaboram diversos gêneros primários (simples), que, nessa condição, transformam-se e adquirem um caráter especial: "perdem o vínculo imediato com a realidade concreta e os enunciados reais alheios" (p. 263). Entretanto, estabelecer a distinção entre gêneros primários e secundários é relevante teoricamente, pois a análise desses dois gêneros é que vai elucidar e definir a natureza do enunciado (BAKHTIN, 2003, p. 264):

A diferença entre os gêneros primário e secundário (ideológicos)é extremamente grande e essencial, e é por isso mesmo que a natureza do enunciado deve ser descoberta e definida por meio da análise de ambas as modalidades: apenas sob essa condição a definição pode vir a ser adequada à natureza complexa e profunda do enunciado (e abranger as suas facetas mais importantes).

Refletindo sobre essas considerações de Bakhtin em relação aos gêneros do Discurso, Brandão (2002, p. 04) aponta dois aspectos que considera importantes:

1. Mesmo sendo cada gênero marcado pela regularidade e pela repetibilidade, por isso definido como relativamente "estável", não é um modelo a ser seguido literalmente, tendo em vista que essa estabilidade é constantemente ameaçada por forças sociais, culturais, de restrição genérica e individuais (estilística) que determinam mudanças, apagamento ou revivescência num gênero. Esse 
movimento marca singularmente os diferentes gêneros; uns mais estáveis, outros mais susceptíveis à variabilidade.

2. A dimensão intra-genérica e inter-genérica que um gênero estabelece com outro no espaço do texto. A primeira corresponde ao diálogo interdiscursivo que se estabelece entre as diferentes manifestações textuais de um mesmo gênero. A segunda considera que, na prática, os discursos/textos não se apresentam homogêneos, ao contrário, na sua produção se entrecruzam vários tipos de gêneros discursivos e de seqüências textuais. São os gêneros, portanto, na prática marcados pela heterogeneidade e pela interdiscursividade/intertextualidade.

No caso desta pesquisa, estamos trabalhando com o gênero discursivo: os depoimentos dos pantaneiros. Sendo os gêneros primários aqueles produzidos nas nossas relações do dia-a-dia, que têm como sua forma mais simples a réplica do diálogo, entendemos ser possível considerar a produção das narrativas como uma das modalidades de diálogo do cotidiano, considerando o que Bakhtin (2003, p. 262) salienta [...] a diversidade das modalidades de diálogo cotidiano é extraordinariamente grande em função do seu tema, da situação e da composição dos participantes." No caso das narrativas, os pantaneiros passam a narrar a sua vida a partir de um pedido da pesquisadora, ou seja, independente da extensão, é uma resposta a essa interlocutora, que, na verdade, vai ainda fazer alguns questionamentos no decorrer da resposta, por isso a modalidade diálogo do cotidiano.

Antes, porém, de tratarmos especificamente da análise, vamos refletir sobre a contituição desses gêneros, a fim de situarmos de forma clara o que estamos entendendo que sejam as narrativas orais. Consideramos que essa reflexão é de fundamental importância para que possamos elucidar a natureza dos enunciados em análise.

\subsection{A RELAÇÃO ORALIDADE ESCRITA}

Neste item procuraremos detalhar um pouco mais sobre a questão do gênero de discurso que compreende o corpus da tese, com a finalidade de tornar claro o que estamos entendendo por narrativas orais e com base em que 
fundamento a nossa escolha por elas. Antes, porém, de tratar especificamente do gênero narrativas, julgamos necessário estabelecer o percurso até esse ponto, iniciando com a tão debatida relação entre oralidade e escrita. Para isso, partimos de autores81 que tratam do assunto desde os primórdios até os nossos dias.

$\mathrm{Na}$ atualidade, a realização de estudos que compreendem questões relativas à oralidade em relação à escrita tem sido uma constante nos diversos campos do conhecimento. Como observa Marcuschi (2001, p. 9) "conhecemos, hoje, muito mais sobre as relações entre oralidade e escrita do que há algumas décadas", entretanto esse conhecimento não se deu sempre de forma tranqüila, ao contrário, os objetivos e pressupostos teóricos que pautaram esses estudos/discussões foram bem heterogêneos e resultaram/resultam em trabalhos relevantes para o aprofundamento do assunto.

Neste capítulo, entretanto, não é nosso objetivo colocar em discussão essas diferenças teóricas entre o oral e o escrito. O propósito é situar, de maneira breve, histórica e socialmente, alguns aspectos da relação entre a oralidade e a escrita de forma a tornar compreensível a natureza do corpus da tese. Para tanto, estarei encaminhando a discussão sobre as relações entre oralidade/escrita tendo em vista os pontos concernentes às minhas indagações.

Iniciaremos a reflexão apresentando as idéias de Eric Havelock, um dos primeiros estudiosos sobre oralidade e cultura escrita, que defendeu a anterioridade do oral sobre o escrito. Em seu artigo A Equação Oralidade - Cultura Escrita: uma fórmula para a mente moderna (1997, p. 17-33), o autor pondera que, com certeza, há um tempo atrás não se teria como tema de um congresso e/ou encontro a questão da oralidade e da cultura escrita, pois a aplicação desse tema encontrava, até bem pouco tempo, muita resistência por parte dos estudiosos mais conservadores. Para o autor (p. 17):

${ }^{8181}$ Considerando o material bibliográfico a que tivemos acesso, tomamos por base o texto de HAVELOCK, E. "A equação oralidade - cultura escrita: uma fórmula para a mente moderna". In: OSLON, D. R. e TORRANCE, N. [1991] Cultura escrita e oralidade. Tradução de Valter Lellis Siqueira. 2 ed. São PAULO-SP: Ática, 1997; o livro de ZUMTHOR, P. [1987]. A letra e a voz - a literatura medieval. Tradução Amalio Pinheiro (parte I) e Jerusa Pires Ferreira (parte II). São PauloSP: Companhia das Letras, 2001; o livro de ONG, W. [1982]. Oralidade e cultura escrita - a tecnologia da palavra. Tradução de Enid Abreu Dobránszky. Campinas-SP: Papirus, 1998; o livro de MARCUSCHI, L. A. Da fala para a escrita - atividades de retextualização. São Paulo-SP: Cortez, 2001 e em relação a histórias de vida o livro de SIMSON, O. de M. V. (Organização e introdução). Experimentos com Histórias de Vida: Itália-Brasil. São Paulo: Vértice - Editora Revista dos Tribunais, 1988. 
[...] atualmente, as expressões oralidade e oralismo têm sentido diferente, expressando conceitos que já se estenderam para além de Homero e dos gregos. Caracterizam sociedades inteiras que têm se valido da comunicação oral, dispensando o uso da escrita. E, por fim, são usadas para identificar um certo tipo de consciência, que se supõe ser criada pela oralidade ou que pode se expressar por meio dela.

O autor observa que esses conceitos se evidenciam a partir da oposição à cultura escrita, também esta estruturada com níveis próprios de linguagem e de conhecimentos expressos por meio da grafia. Essa oposição entre oralidade e cultura escrita individualiza-as, mesmo sendo vistas como interligadas socialmente. Para Havelock, entretanto, polarizá-las, pressupondo-as como mutuamente exclusivas, é um erro, já que entre elas se estabelece uma relação de tensão mútua e criativa, primeiramente numa dimensão histórica, tendo em vista que a cultura escrita surge no contexto de uma cultura oral e, em uma dimensão mais recente, em que se busca uma compreensão do que essa cultura escrita - superposta à oralidade em que nascemos e que dirige nossas atividades cotidianas — significa para nós.

A ruptura da hegemonia da cultura escrita sobre a oralidade se deu na década de 60, mais precisamente, em um período de, mais ou menos um ano (19621963), em que se registra o surgimento de quatro publicações de estudiosos ${ }^{82}$ sobre o assunto. Nas obras desses estudiosos - que, ao que se saiba, não mantinham nenhum tipo de diálogo entre si - a tônica principal era a de que a oralidade e o oralismo deveriam ser colocados em evidência (p.18).

Em seguida, Havelock vai pontuar aspectos históricos da questão oralidade/cultura escrita, por meio das idéias dos autores das obras consideradas de ruptura e outros estudiosos que se constituíram como predecessores ${ }^{83}$ e/ou

${ }^{82}$ Os estudiosos a quem havelock se refere e suas obras são:The Gutenberg Galaxy ( $A$ galáxia de Gutenberg), de McLuhan (1962); La pensée sauvage (O Pensamento selvagem), de Lévi-Strauss (1962); um artigo de Jack Goody e lan Watt "The Consequences of Literacy" ("As conseqüências da cultura escrita") (1963) e, finalmente, Preface to Plato (Prefácio para Platão), de autoria do próprio Havelock (1963). Segundo o autor, as obras mencionadas, apesar de percorrerem caminhos teóricos diferentes e tematizarem objetos também diferentes, podem ser consideradas em "um divisor de águas" que oportunizou o início de uma série de publicações sobre as relações entre oralidade e cultura escrita.

83 Os predecessores dessas obras, mencionados por Havelock são: L'Epithèt traditionelle dans Homere (O epíteto tradicional em Homero) Milman Parry (1971), que deu origem à moderna teoria 
herdeiros da equação oralidade - cultura escrita. Em último lugar vêm as idéias defendidas pelo próprio Havelock, em que vai apresentar o que denomina "as causas" que possibilitaram a equação oralidade - cultura escrita. Essas causas, para o autor, aconteceram mais ou menos um milhão de anos ou mais antes dos gregos e compreendem o desenvolvimento do cérebro humano (extremamente desenvolvido) e a singularidade anatômica do corpo humano que possibilita a articulação da linguagem. Dessa maneira, o que realmente nos identifica como seres humanos é a língua: [...] o ser humano natural não é escritor ou leitor, mas falante e ouvinte" (p. 27). Benveniste, em um texto que trata da subjetividade da linguagem, afirma também que [...] é um homem falando que encontramos no mundo, um homem falando com outro homem, e a linguagem ensina a própria definição de homem" (1991, p. 285).

Da perspectiva acima defendida por Havelock, duas conclusões em relação à história da oralidade podem ser colocadas. A primeira delas, é aquela que postula terem [...] as sociedades humanas pré-históricas se formado com base na intercomunicação por meio da língua, fossem seus membros caçadores e colhedores de frutos, agricultores ou algo intermediário entre essas duas categorias" (1997, p. 27). Para o autor, todas as negociações, acordos e outras transações concernentes à vida em sociedade, por longo período, foram realizadas por meio da oralidade. A segunda preceitua que, sendo a oralidade uma habilidade que faz parte de nós da mesma forma que andar ereto ou usar as mãos, não se deixou suplantar pela cultura escrita. Podemos perceber, então, nas idéias de Havelock (p.27-28) a defesa que este faz da anterioridade do oral em relação ao escrito, pois mesmo com o advento da escrita:

[...] pode-se concluir que, dos egípcios e sumérios aos fenícios e hebreus (para não mencionar os indianos e os chineses), a escrita nas sociedades onde era praticada restringiu-se às elites clericais ou comerciais, que se davam ao trabalho de aprendê-la. As atividades ligadas à justiça, governo e vida cotidiana ainda eram comandadas

oralista homérica da composição; The bias of communication ( $O$ viés da comunicação), de Harold Innis (1951), que deu um grande impulso para a questão oralidade - cultura escrita; The singer of tales (O cantor de histórias), de Albert Lord (1960), que comparou Homero com os modos de composição oral que ainda hoje sobrevivem nos Bálcãs; Ramus, method and decay of dialogue (Ramus:método e decadência do diálogo), de Walter Ong (1958), cujo estudo se constituiu em uma exposição preliminar que estaria relacionado à equação oralidade - cultura escrita advindo do estudo da prática da retórica. Conf. HAVELOCK, 1997, p.19-21. 
pela comunicação oral, como hoje ainda acontece em grande parte do mundo islâmico e até mesmo na China.

Em outro trecho do item em que expõe as suas idéias, o autor — ao tratar da importância de alguns hábitos lingüísticos orais - reafirma essa anterioridade explicando que [...] esses hábitos lingüísticos orais fazem parte de nosso legado biológico, que pode ser complementado pela cultura escrita, mas jamais suplantado por ela" (p. 31).

Entretanto, o autor não deixa de reconhecer a importância da cultura escrita e atribui o êxito dessa modalidade à superioridade da tecnologia do alfabeto grego. E assim se expressa:

[...] Sem a moderna cultura escrita, o que significa a cultura escrita grega, não teríamos a ciência, a filosofia, a lei escrita ou a literatura e, tampouco, o automóvel ou o avião. Algo aconteceu para que todas essas conquistas se tornassem possíveis. Uma lenta revolução estava acontecendo enquanto Platão escrevia, e o sucesso de seu segredo estava na tecnologia superior do alfabeto grego.

Ong $^{84}$ (1998) é, como Havelock, um estudioso do fenômeno da oralidade em relação com a escrita e como este defende a anterioridade daquela em relação a esta. Nesse sentido, Ong considera importante abordá-las não só em uma dimensão sincrônica - que se faz pela comparação entre culturas orais e culturas escritas que coexistem num dado período - mas também em sua dimensão diacrônica ou histórica, aspecto que julga absolutamente essencial pela comparação entre períodos sucessivos. O autor (1998, p. 10) afirma que

[...] a sociedade humana primeiramente se formou com a ajuda do discurso oral, tornando-se letrada muito mais tarde em sua história, e inicialmente apenas em certos grupos. O Homo sapiens existe há cerca de 30.000-50.000 anos. O mais antigo registro escrito data de apenas 6.000 anos atrás. O estudo (...) estabelece um quadro de referência no qual é possível entender melhor não apenas a primitiva cultura oral e a subseqüente cultura escrita, mas também a cultura

\footnotetext{
${ }^{84}$ Walter Ong, como já referido, é autor da obra Oralidade e cultura escrita - a tecnologização da palavra, que traz como tema as diferenças entre oralidade e cultura escrita. Para ele, já que estamos intimamente familiarizados com a cultura escrita, o tema primeiro de seu livro é o pensamento e sua expressão verbal na cultura oral e, por último, o pensamento e a expressão na cultura escrita.
} 
impressa, que leva a escrita a um novo patamar, e a cultura eletrônica, que se apóia tanto na escrita como na impressão.

O autor reconhece o papel relevante da escrita, mas, a despeito de todas as possibilidades de avanço que esta trouxe à palavra falada ainda subsiste e vive: [...] a mesma fascinação pelo discurso oral continua inalterada séculos depois de a escrita ter sido posta em uso" (p. 17).

A questão da oralidade, no contexto social, é qualificada por Ong (p. 19) em "oralidade primária" - aquela de uma cultura desprovida de qualquer conhecimento da escrita ou da impressão. Ela é "primária" em oposição à "oralidade secundária" — aquela da atual cultura de alta tecnologia, na qual uma nova oralidade é alimentada pelo telefone, pelo rádio, pela televisão ou por outros eletroeletrônicos com existência e funcionamento que dependem da escrita e da impressão. O autor pondera que não é fácil pensar em termos de uma tradição genuinamente oral ou a oralidade primária de forma precisa e significativa, tendo em vista que, hoje, estamos profundamente influenciados pela escrita.

Considerando os depoimentos orais que compõem o corpus de nossa análise, vale ressaltar que, segundo Ong (p. 53), as culturas orais "conceituam e verbalizam todo o seu conhecimento com uma referência mais ou menos próxima ao cotidiano da vida humana" em uma interação imediata, conhecida entre seres humanos. Afinal, são desprovidas de categorias analíticas aprimoradas, que usam a escrita para organizar o conhecimento distante da experiência vivida.

Paul Zumthor ${ }^{85}$ (1993) é um estudioso que compartilha das idéias defendidas pelos autores acima referidos no que diz respeito ao interesse que demonstra pela relação entre a oralidade e a escrita sempre com ênfase na primeira. Para o autor (1993, p. 35):

[...] admitir que um texto, num momento qualquer de sua existência, tenha sido oral é tomar consciência de um fato histórico que não se confunde com a situação de que subsiste a marca escrita, e que jamais aparecerá (no sentido próprio da expressão) "a nossos olhos".

\footnotetext{
${ }^{85}$ Paul Zumthor é um medievalista suíço que realizou um estudo sobre a poesia medieval em $A$ Letra e a Voz que, segundo afirma Jerusa Pires Ferreira, no posfácio do livro, é para os estudiosos de literatura, de cultura medieval e de literaturas orais, uma obra que se configura como um divisor de águas, como uma obra fundante.
} 
Em seu estudo, o autor destaca três tipos de oralidade que correspondem a três situações de cultura. Semelhantemente a Ong ${ }^{86}$, Zumthor tem no primeiro deles a oralidade primária e imediata que compreende as culturas sem nenhum contato com a escritura. Ela se encontra, portanto, em sociedades desprovidas de todo e qualquer sistema de simbolização gráfica, ou em grupos sociais isolados e analfabetos.

Ao segundo tipo, denominou oralidade mista, situação em que a influência do escrito permanece externa, parcial e atrasada. Esse tipo de oralidade tem seu fundamento em culturas "possuidoras de uma escritura".

O terceiro tipo foi nomeado pelo autor de oralidade segunda, quando se recompõe por meio da escritura em um contexto no qual esta tende a esgotar os valores da voz no uso e no imaginário. Esse tipo de oralidade se presentifica em uma cultura "letrada", [...] na qual toda expressão é marcada mais ou menos pela presença da escrita” (p. 18-19). No capítulo de análise, tentarei situar os depoimentos orais que compõem o corpus da tese no tipo de oralidade que o autor denomina de oralidade mista.

Marcuschi (2001) é um dos pesquisadores brasileiros que, há longo tempo, tem se dedicado ao estudo da oralidade em sua relação com a escrita. Na obra aqui referida (Da fala para a escrita - atividades de retextualização), o autor afirma não é possível realizar uma investigação sobre oralidade e letramento ${ }^{87}$ sem considerar o papel que essas práticas representam na atualidade, nem tratar das semelhanças e diferenças entre fala e escrita sem observar a disposição de seus usos na vida cotidiana. Dessa maneira, o autor considera que essas atividades se constituem em um conjunto de práticas sociais, em razão de uma mudança de perspectiva em que é outro o objeto de análise e outra a concepção de língua e de texto.

${ }^{86}$ Ong, como já referido anteriormente neste trabalho, faz duas classificações para a oralidade, sendo que a primeira delas é nomeada de oralidade primária como o faz também Zumthor.

${ }^{87}$ Segundo 0 autor a expressão letramento poderia interpretada como alfabetização, porém ele considera que este, ao mesmo tempo em que seria correto seria redutor, porque letramento, neste caso, está englobando outros aspectos que não só a alfabetização formal e pedagogicamente realizada. Para ele, o letramento envolve as mais diversas práticas da escrita (nas suas variadas formas) na sociedade e pode ir desde uma apropriação mínima da escrita, tal como o indivíduo que é analfabeto, mas letrado na medida em que identifica o valor do dinheiro, identifica o ônibus que deve tomar, consegue fazer cálculos complexos, sabe distinguir as mercadorias pelas marcas, etc., mas não escreve cartas nem lê jornal regularmente, até uma apropriação profunda, como no caso do indivíduo que desenvolve tratados de Filosofia e Matemática ou escreve romances. Letrado é o indivíduo que participa de forma significativa de eventos de letramento e não apenas aquele que faz um uso formal da escrita ( MARCUSCHI, 2001, p.16 e 25). 
A partir dos anos 80, essa mudança de enfoque vai ocorrer em contraponto aos estudos das três décadas anteriores em que - num claro predomínio da noção de supremacia cognitiva da escrita - a oralidade e a escrita são opostas. Considerava-se a relação oralidade e letramento como dicotômica, não sendo possível, dessa maneira, considerá-las como práticas sociais.

Observa o autor que, muito embora em uma sociedade como a nossa, "a escrita, enquanto manifestação formal dos diversos tipos de letramento, é mais do que uma tecnologia" (p. 16). A escrita tornou-se indispensável para o dia-a-dia, tanto nos centros urbanos como no meio rural e pode ser vista como essencial à própria sobrevivência do mundo moderno. Sua prática e avaliação social conferiram-lhe um status que a coloca como símbolo de educação, desenvolvimento e poder.

Ainda assim, como afirma Marcuschi, [...] sob o ponto de vista mais central da realidade humana, seria possível definir o homem como um ser que fala e não como um ser que escreve" (p. 17). Isso não significa, no entanto, que a oralidade seja superior à escrita, nem autoriza afirmações de que a escrita é derivada e a fala é primária:

[...] oralidade e escrita são práticas e usos da língua com características próprias, mas não suficientemente opostas para caracterizar dois sistemas lingüísticos nem uma dicotomia. Ambas permitem a construção de textos coesos e coerentes, ambas permitem a elaboração de raciocínios abstratos e exposições formais e informais, variações estilísticas, sociais, dialetais e assim por diante (p. 17)

E mais:

[...] postular algum tipo de supremacia ou superioridade de alguma das duas modalidades seria uma visão equivocada, pois não se pode afirmar que a fala é superior à escrita ou vice-versa. Em primeiro lugar, deve-se considerar o aspecto que se está comparando e, em segundo, deve-se considerar que esta relação não é homogênea nem constante (p. 35).

[...] na sociedade atual, tanto a oralidade quanto a escrita são imprescindíveis. Trata-se, pois, de não confundir seus papéis e seus contextos de uso, e de não discriminar seus usuários (p. 22). 
Em seu livro, Marcuschi (p. 27-34) apresenta várias tendências ${ }^{88}$ que fundamentam estudos sobre a relação entre oralidade e escrita: a) perspectiva das dicotomias, b) tendência fenomenológica de caráter culturalista, c) perspectiva variacionista, d) perspectiva sociointeracionista. Neste trabalho trataremos da quarta tendência porque pressupõe uma visão interacionista das duas modalidades, percebendo-as como práticas sociais, cuja relação postula um continuum e nunca uma dicotomia polarizada, estando, assim, muito próxima da perspectiva teórica que fundamenta a análise do corpus da tese.

Essa é uma tendência fortemente defendida no Brasil e, segundo o autor, tem entre seus estudiosos mais representativos Preti (1991, 1993), Koch (1992), Marcuschi (1986, 1992, 1995), Kleiman (1995a), Urbano (2000) e muitos outros com produções presentes nas obras editadas por Petri (1993, 1994, 1998 e 2000).

Fundamentados nessa linha são desenvolvidos, entre outros, dois grandes projetos: o Projeto NURC/SP (coordenado por Dino Preti) e o Projeto da "Gramática do Português Falado", dirigido por Ataliba de Castilho, com várias publicações sobre a língua falada, haja vista os vários volumes publicados pela Humanitas sobre os trabalhos do Projeto NURC/SP e as "Gramáticas do Português Falado" publicadas pela Editora da UNICAMP - Campinas/SP.

Conforme observa o autor, a perspectiva interacionista interessa-se pelos processos de produção de sentido considerando-os no interior de contextos sóciohistoricamente marcados por atividades de negociação ou por processos inferenciais. Nessa perspectiva, fala e escrita - diferentemente das outras tendências com relações sempre dicotômicas - apresentam: dialogicidade, usos estratégicos, funções interacionais, envolvimento, negociação, situacionalidade, coerência e dinamicidade.

As relações entre fala e escrita, neste caso, não são óbvias nem lineares, ao contrário, apresentam um constante dinamismo fundamentado no continuum que se evidencia entre essas duas modalidades de uso da língua. Igualmente não se pode admitir polaridades estritas e dicotomias estanques.

\footnotetext{
${ }^{88}$ Maiores informações sobre essas tendências o leitor encontra em MARCUSCHI, L.A. Da fala para a escrita - atividades de retextualização. São Paulo: Cortez, 2001, p. 27-35).
} 
Marcuschi (p. 43) encerra esta parte de sua obra, ressaltando a noção de língua que permeia essa tendência, qual seja:

[...] um fenômeno heterogêneo (com múltiplas formas de manifestação), variável (dinâmico, suscetível a mudanças), histórico e social (fruto de práticas sociais e históricas), indeterminado sob o ponto de vista semântico e sintático (submetido às condições de produção) e que se manifesta em situações de uso concretas como texto e discurso.

Além do entendimento da breve reflexão que se fez da relação oralidade e escrita e do papel da oralidade no contexto atual, procuraremos, retomando o que já mencionamos, situar as narrativas orais nesse contexto voltado para a pesquisa, no caso desta tese. Como, no nosso entender, os fenômenos não são estanques e nem ocorrem de forma fragmentada, o que foi mencionado acima será retomado nas reflexões que faremos a seguir.

\subsection{NARRATIVAS ORAIS... DEPOIMENTOS... HISTÓRIAS DE VIDA}

Por muito tempo ${ }^{89}$ o "relato"oral, a narrativa oral ficou relegada a um segundo plano, notadamente com o advento da escrita. Nas últimas décadas, entretanto, a denominada "história oral" reaparece valorizada, especialmente como um corpora importante para os cientistas sociais que, em razão do seu sucesso nessa área, passaram a tê-la como a técnica por excelência capaz de se contrapor às quantitativas, como observa Queiroz (1988, p. 14). Alguns sociólogos - mesmo utilizando a técnica da história de vida - argumentavam que esta evidenciava parcialmente a realidade, mas era importante para captar o não explícito.

${ }^{89}$ Do início do Séc. XX até os anos 50, a "história oral" foi utilizada nas pesquisas de alguns sociólogos, tais como: W.I. Thomas (1863-1947) e F. Znaniecki (1882-1958) em pesquisa conjunta, no período que foi de 1918 a 1920. Outros que se utilizavam das histórias orais em suas pesquisas foram J.Dollard (1900) e antropólogos como Franz Boas (1858-1942), geógrafo alemão, naturalizado americano em 1886, que se converteu à antropologia e que realizou pesquisa com relatos e depoimentos de velhos caciques e pajés, para evitar o desaparecimento da memória da vida tribal. Esses cientistas sociais tinham na história oral e, principalmente na história de vida, uma ferramenta fundamental para suas disciplinas. QUEIROZ, M.I. P. "Relatos orais: do "indizível" ao "dizível". In: SIMSON, O. de Moraes Von. (Orga.) Experimentos com Histórias de Vida (Itália-Brasil). São PauloSP: Vértice, Editora Revista dos Tribunais, 1988. 
Com o desenvolvimento das pesquisas quantitativas que tinham nas estatísticas o seu ponto alto, os relatos orais e histórias de vida passaram à penumbra por que eram muito sucetíveis à influências da psique individual. No entanto, com o passar do tempo, os pesquisadores constataram que "valores e emoções permaneciam escondidos nos próprios dados estatísticos" (p. 15), pois a definição do objeto de pesquisa e a elaboração das questões eram realizadas pelo pesquisador, não isento, na leitura dos dados, de suas concepções e pontos de vista. Dessa forma, perdiam os números a sua pura objetividade.

A invenção do gravador vai reavivar o relato oral, já que as fitas podiam não só conservar a narração, mas também - despojando o pesquisador do simples registro no papel - captar, na voz do entrevistado, as entonações, pausas, seus vaivém do relato. Esses dados se constituíam como preciosos para novos estudos, além do já levantado.

Da segunda metade do séc. XX em diante, se intensificam as discussões sobre a oralidade e ela passa a ter um desenvolvimento significativo. No caso da linguagem, as concepções que pregam a primazia da escrita cedem lugar às concepções que vão defender que não há primazia e sim caraterísticas próprias a cada uma delas, mas que sustentam uma dicotomia e uma importância maior para uma ou a outra. Segundo Marcuschi (2001, p. 37), [...] as diferenças entre fala e escrita se dão dentro do continuum tipológico das práticas sociais de produção textual e não na relação dicotômica de dois pólos opostos".

Nessa perspectiva, muitos estudos e pesquisas já foram e estão sendo realizados com a oralidade e especificamente com história oral. Mas afinal, o que compreende o termo "história oral"? Segundo Queiroz (p. 19), é um termo amplo que recobre uma variedade de relatos sobre fatos não registrados por outro tipo de documentação. Normalmente colhida através de entrevistas, as mais variadas, registra a experiência de um ou vários indivíduos de uma dada coletividade e pode obter tanto a experiência efetiva dos sujeitos, como suas tradições, mitos e crenças existentes no grupo. No entender da autora [...] tudo quanto se narra oralmente é história, seja a história de alguém, seja a história de um grupo, seja história real, seja ela mítica".

No que diz respeito aos vários relatos que se agregam a este termo mais amplo que é a história oral, temos a "história de vida" e semelhantes a ela: as 
entrevistas, os depoimentos pessoais, as autobiografias, as biografias. Esses relatos fornecem material para os pesquisadores, mas se definem e caracterizam-se diferentemente. A entrevista é a mais antiga e a mais utilizada forma de coleta de dados, nas ciências sociais. Nem por isso deixa de dividir opiniões, já que uns a tem como a técnica por excelência da coleta e outros a qualificam como desvirtuadora dos relatos. Apesar das críticas, nunca chegou a ser totalmente descartada.

A entrevista compreende um diálogo, uma conversação continuada entre o informante e o pesquisador. Conforme observa Queiroz (p. 20), o tema ou o acontecimento que pauta o diálogo entre os interlocutores é escolhido por este último conforme os objetivos de seu trabalho ou seja, o pesquisador dirige a entrevista, utilizando um roteiro previamente elaborado ou aparentemente sem um roteiro. Aparentemente porque, na verdade, a conversa se desenrola seguindo uma sistematização de assuntos que o pesquisador já tem. No entender da autora, a entrevista, na verdade, se faz presente em todas as formas de coleta dos relatos orais, se considerarmos que estes sempre implicam num colóquio entre pesquisador e narrador.

A história de vida se constitui no relato de um locutor sobre sua vida através do tempo, situação em que procura relatar os acontecimentos que vivenciou e passar aos outros a experiência adquirida. Nessa narrativa evidenciam-se as relações com a comunidade, com os membros de seu grupo profissional, de sua classe social, com a sociedade como um todo, que convém ao pesquisador constatar. $O$ interesse deste, portanto, é captar algo singular que vá além do que é relatado e que se situa no contexto das relações sociais a que o narrador pertence. Nem por isso, o pesquisador deve interferir muito no relato, ou seja, a sua interferência neste tipo de coleta de dados deve ser, preferencialmente, mínima. Para Queiroz (p. 20):

[...] Avanços e recuos marcam as histórias de vida; e o bom pesquisador não interfere para restabelecer cronologias, pois sabe que também estas variações no tempo podem constituir indícios de algo que permitirá a formulação de inferências [...].

Outra especificação relevante da história de vida é o fato de se constituir em uma técnica cuja aplicação demanda tempo. Uma técnica que não se esgota em um ou dois contatos, pois o que o informante tem para relatar de si mesmo, na maioria 
das vezes, demanda mais tempo, sem contar que a duração deve ser limitada para não the causar cansaço e nem ao pesquisador. Além disso, vale ressaltar que no caso das histórias de vida quem decide o que vai relatar é o narrador, muito embora o pesquisador implicitamente dirija a interlocução.

Segundo Queiroz (p. 21), as histórias de vida compreendem um conjunto de depoimentos. Termo que, como observa a autora, foi inicialmente utilizado - e acrescentamos que o é até hoje - no meio jurídico no contexto de uma investigação que tem como finalidade "estabelecer a verdade dos fatos". Nas ciências sociais, depoimento é definido como o relato de algo que o informante efetivamente presenciou, experimentou, ou de alguma forma conheceu, podendo assim atestar.

No entender da autora, o depoimento vai diferir da história de vida, no que diz respeito à postura do pesquisador ao utilizar cada uma dessas técnicas. No caso do depoimento, o pesquisador dirige diretamente o diálogo; no caso da história de vida, como já vimos, o pesquisador até tem um encaminhamento, mas quem comanda o fio do relato é o informante. Na primeira técnica o pesquisador tem 0 controle nas mãos; na segunda, o informante é quem detém o fio condutor.

Mais adiante, Queiroz (p. 22) vai ressaltar que, na verdade, o informante não tem o domínio absoluto do fio condutor da narrativa, já que o pesquisador foi quem escolheu o tema da pesquisa, formulou as questões que deseja esclarecer e propôs o problema. Portanto, o comando é deste, embora procure não intervir durante a narração. Não impõe ao narrador o que dizer, ficando ao critério deste abordá-los de forma completa ou não.

A autobiografia e a biografia consistem na narração da vida de uma pessoa. Isso poderia levar-nos a enquadrá-las como histórias de vida tomadas em sentido lato,entretanto, há diferenças como no caso das histórias de vida e dos depoimentos pessoais. A autobiografia, conforme a formação da própria palavra aponta, existe sem o pesquisador. Os objetivos são outros e o encaminhamento da técnica é outro, é o narrador que, sozinho, e por motivos estritamente pessoais, se dispõe a relatar a sua vida e dá a esse texto o encaminhamento que melhor the parecer.

A biografia, por sua vez, constitui-se na história de vida de uma pessoa redigida por outra. $O$ objetivo aqui está focado na existência individual e não nas relações sociais a que pertence tal indivíduo. Nesse caso, temos a presença do pesquisador, ou de alguém que, mesmo não sendo um pesquisador, tem um 
objetivo e/ou uma razão para escrever sobre a vida daquela pessoa. Para Queiroz (p. 23)

Existe aqui a dupla intermediação que a aproxima da história de vida, consubstanciada na presença do pesquisador e no relato escrito que sucede às entrevistas. O objetivo do pesquisador é desvendar a vida particular daquele que está entrevistando ou cujos documentos está estudando, mesmo que neste estudo atinja a sociedade em que vive o biografado, o intuito é, através dela, explicar os comportamentos e as fases da existência individual. A finalidade é sempre um personagem, isto é, uma pessoa encarada em suas ações e em suas qualidades, naquilo que faz e diz através do tempo, em variadas situações e circunstâncias.

Considerando que, neste caso, o que se busca destacar são as características de um personagem, a meta de um biógrafo, ao escrever-lhe a biografia, é diferente da do pesquisador que utiliza a técnica de histórias de vida. Segundo a autora (p. 24):

O primeiro fará ressaltar em seu trabalho os aspectos marcantes e inconfundíveis do indivíduo cuja existência decidiu revelar ao público. O segundo busca, com as histórias de vida, atingir a coletividade de que seu informante faz parte, e o encara, pois, como mero representante da mesma através do qual se revelam os traços desta. Mesmo que o cientista social registre somente uma história de vida, seu objetivo é captar o grupo, a sociedade de que ela é parte; busca encontrar a coletividade a partir do indivíduo. O biógrafo, mesmo que retrate a sociedade de que seu personagem participa, o faz com o intuito de compreender melhor a existência do biografado.

Outro aspecto relevante que diferencia a biografia da história de vida diz respeito à utilização da biografia que, por tratar do indivíduo compreendido em sua integralidade, não pode ser analisada em partes ou utilizada em fragmentos, sob pena de se perder completamente o sentido pretendido: o desenvolvimento da personalidade, [...] isto é, do "eu" único e permanente que, embora evoluindo através do tempo, mantém certa linha constante que o distingue dos demais". Fragmentá-la é um grave risco, risco de levar a graves falhas na análise e na compreensão dos aspectos sobre os quais se quer refletir. Há casos, porém, em que o recorte do material é, no entender de Queiroz (p. 25), mesmo necessário. É o caso dos estudos sociológicos ou antropológicos, em que a utilização da biografia ou de autobiografia 
se faz no sentido pesquisar como se constituem as relações da pessoa com seu grupo, com sua comunidade.

Não se trata de considerá-lo isoladamente, nem de compreendê-lo em sua unicidade; o que se quer é captar através de seus comportamentos, o que se passa no interior das coletividades de que participa. O individuo não é mais o "único"; ele agora é uma pessoa indeterminada, que nem mesmo é necessário nomear, é somente unidade dentro da coletividade. Todavia, em seu anonimato, contém indivíduo num microcrocosmo as configurações que sua coletividade abarca, ao ordenar umas em relação às outras unidades, de que se compõem o grupo.

Estabelecidos esses parâmetros dos relatos orais, esclarecemos que as narrativas orais dos peões pantaneiros se enquadram no gênero de discurso depoimento pessoal, tendo em vista que, antes de iniciar a gravação, apresentamoIhes um roteiro com aspectos que gostaria que não fossem esquecidos e em alguns momentos retomei-os durante o relato. Através do depoimento vai ser possível capatar o cotidiano e a representação que este peão faz do espaço em que vive e atua e da cultura dessa região. 
Descobri aos 13 anos que o que me dava prazer nas leituras não era a beleza das frases, mas a doença delas.

Comuniquei ao Padre Ezequiel, um meu Preceptor, esse gosto esquisito.

Eu pensava que fosse um sujeito escaleno.

- Gostar de fazer defeitos na frase é muito saudável, o Padre me disse.

Ele fez um limpamento em meus receios.

O Padre falou ainda: Manoel, isso não é doença, pode muito que você carregue para o resto da vida um certo gosto por nadas...

E se riu.

Você não é de bugre? - ele continuou.

Que sim, eu respondi.

Veja que bugre só pega por desvios, não anda em estradas -

Pois é nos desvios que encontra as melhores surpresas e os ariticuns maduros.

Há que apenas saber errar bem o seu idioma.

Esse Padre Ezequiel foi o meu primeiro professor de agramática. (Manoel de Barros, Para encontrar o azul eu uso pássaros, 1999) 


\section{CAPÍTULO V}

\section{O VIVIDO E O HOMEM PANTANEIRO}

No uso de cantos e recontos O pantaneiro encontra o seu ser.

Aqui ele alcança a altura das manhãs

E os cinzentos do entardecer. (MANOEL DE BARROS, 1998).

\subsection{OS PANTANEIROS: O DISCURSO E AS CONDIÇÕES DE PRODUÇÃO}

O corpus de nossa análise se constitui de quatro depoimentos de pantaneiros, todos nascidos no Pantanal. Moraram em várias fazendas dos Pantanais, indo para a cidade no período de prestar o serviço militar. Um deles residiu um tempo maior na cidade: oito anos, e o pantaneiro que está aposentado hoje mora na cidade de Aquidauana, mas continua prestando serviços a alguns fazendeiros pantaneiros. Esses pantaneiros residem/residiram, portanto, nos Pantanais há mais de trinta anos.

O nosso encontro com cada um deles ocorreu em situações específicas, que relatamos a seguir. Procuramos explicitar, em detalhes, esses encontros, pois são importantes para entendermos o contexto imediato dos peões pantaneiros no momento da pesquisa de campo.

O primeiro depoimento (doravante D1) é de S.N.C ${ }^{90}$, pantaneiro com 45 anos que atualmente trabalha na Fazenda Paloma, distrito de Taboco ${ }^{91}$. O primeiro contato foi feito através de um aluno nosso que é da região e atendendo-nos, contactou com este pantaneiro e mais outros dois.

\footnotetext{
${ }^{90}$ Os pantaneiros não expressaram nenhum tipo de preocupação em serem citados nominalmente, mas, por uma questão de privacidade de cada um deles, preferimos referi-los pelas iniciais dos Inomes a cada momento em que for preciso citá-los.

${ }^{91}$ Essa fazenda está situada na região que eles denominam de "alto Pantanal" e/ou "alto da serra", onde a ocorrência de enchentes é rara. Fomos até lá em meu próprio carro. Acompanhou-nos um de nossos sobrinhos que auxiliou-nos na viagem, pois havia trechos sem pavimentação asfáltica para chegar ao distrito e depois chegar até as fazendas.
} 
O pantaneiro recebeu-nos em um domingo, no período da tarde, em sua residência, que fica em um retiro da fazenda. Sua casa é de madeira, pintada, confortável, com móveis simples e com um pequeno jardim na frente. Tem cerca de balaústre ${ }^{92}$ e situa-se em frente a um grande açude ${ }^{93}$, com uma vista muito bonita.

Após as apresentações, feitas pelo aluno que nos acompanhou até lá, explicamos a finalidade de estarmos ali e reiteramos a pergunta se ele concordava em contar sua história de vida para nós. Esclarecemos que a nossa conversa seria gravada, transcrita e faria parte do trabalho escrito que motivou a nossa visita. Recebendo a resposta afirmativa, perguntamo-Ihe se conversaríamos ali na varanda onde estávamos, ou se ele gostaria de gravar a conversa em outro local. Fizemos essa pergunta em razão de estarmos na varanda de sua casa, junto com o aluno que nos acompanhou e sua esposa, meu sobrinho, além de toda a família do próprio pantaneiro, pois ele poderia preferir não conversar na presença das pessoas que nos acompanhavam. Ele, porém não teve nenhum problema em conversar ali mesmo, sentado na mureta da sua varanda ${ }^{94}$.

Esclarecidos esses aspectos, apresentamo-lhe o roteiro da nossa conversa, explicitando cada um dos itens. Acrescentamos que aquele era só um roteiro que tínhamos como parâmetro para iniciar a conversa, e que ele ficasse à vontade para contar sua vida da maneira que desejasse e como desejasse. Esclarecemos ainda que não ficaríamos interrompendo a sua fala, pois gostaríamos de ouvi-lo.

A gravação foi realizada com muita tranqüilidade. S. N. C. não se sentiu constrangido diante do gravador, ao contrário, mostrou-se satisfeito em nos contar sua história ${ }^{95}$. A gravação ${ }^{96}$ durou mais ou menos uma hora e dez minutos sem intervalo, porque ele não quis parar para descansar. Embora não tenha feito muitas

\footnotetext{
${ }^{92}$ Cerca de ripas de madeira que são pregadas a uma distância regular umas das outras e que formam a cerca.

${ }_{93}$ Lago formado por represamento das águas.

94 Entretanto, um pouco depois, as pessoas que me acompanhavam resolveram dar uma volta nos arredores da fazenda e visitar uma cachoeira que existe bem perto da casa, ficando só

${ }_{95}$ Concluímos que ele sentiu-se valorizado por estar colaborando com o nosso trabalho, tendo em vista que, na hora da nossa saída, quando agradecemos a ele por nos atender, disse que ele é que agradecia em poder colaborar com a pesquisa e colocou-se a disposição, caso necessitássemos de conversar em um outro momento.

${ }^{96}$ No que diz respeito às transcrições das fitas e a digitação, estas foram feitas a algumas mãos. No primeiro momento, encarregamo-nos pessoalmente da transcrição, depois, em razão dos outros trabalhos, recebemos a ajuda de parente próximo. Finalmente, pagamos uma pessoa para finalizar esse trabalho ${ }^{96}$ As transcrições obedeceram ao quadro NORMAS PARA TRANSCRIÇÃO do Projeto NURC/SP $P^{96}$ (em anexo).
} 
interferências, em relação às outras conversas, esta foi a conversa em que mais perguntamos $^{97}$. Não houve interferência/complementações ou acréscimos por parte de outras pessoas da família.

A segunda história (doravante D2) é de J.Q., pantaneiro aposentado, com 70 anos, que reside na cidade de Aquidauana-Alto Pantanal ${ }^{98}$. O primeiro contato foi feito por telefone, que conseguimos com o fazendeiro para quem o pantaneiro presta serviços $^{99}$. Ligamos para sua residência e falamos com sua esposa, pois ele se encontrava trabalhando no Pantanal. Ela marcou o dia para ligarmos e conversarmos com ele. No segundo telefonema, encontramo-lo e ele prontamente concordou em nos receber e marcou dia e hora que nos esperaria em sua residência. Na data combinada fomos até a cidade de ônibus e - muito embora ele tivesse passado o endereço - fez questão de nos buscar na rodoviária.

Sua esposa recebeu-nos, na sala de visitas da casa Uma casa de alvenaria, bem mobiliada, com um amplo jardim, murada, com grade na frente e portão eletrônico. Apresentamo-nos e explicamos a nossa finalidade ali, os objetivos do trabalho e perguntamo-Ihe se concordava em nos contar sua história de vida. Esclarecemos que a nossa conversa seria gravada, transcrita e faria parte do trabalho escrito que motivou a nossa visita. Respondeu-nos que sim e disse que estava a nossa disposição para começar a gravar. Apresentamo-lhe, então o roteiro da nossa conversa, explicitando cada um dos itens. Da mesma forma que na conversa com S.N.C, acrescentamos que aquele era só um roteiro que tínhamos como parâmetro para iniciar a conversa, e que ele poderia ficar à vontade para contar sua vida da maneira que desejasse e como desejasse. Igualmente, esclarecemos ainda que não ficaríamos interrompendo a sua fala, pois estávamos ali para ouvi-lo.

\footnotetext{
${ }^{97}$ As interferências constituíram-se de retomadas de algumas questões do roteiro que não tinham ainda sido pontuadas pelo pantaneiro. Nas outras narrativas, ocorreu situação semelhante. Outras interferências foram de pedido de detalhes e/ou maiores esclarecimentos sobre os assuntos tratados, bem como de marcadores discursivos produzidos pela interação/envolvimento com o locutor: ahn ahn, certo.

${ }_{98}$ A cidade de Aquidauana é considerada, na região, como o Portal do Pantanal.

${ }^{99} \mathrm{O}$ telefone do pantaneiro nós conseguimos em uma das nossas viagens de São Paulo a Campo Grande - MS, em que, em razão do social que nos constitui, tivemos de esperar algumas horas na estrada por conta do protesto de um grupo do Movimento Sem-Terras. Conversando com as pessoas que conosco se encontravam, conhecemos o Sr. L. que, sabendo ali da nossa pesquisa, falou-nos de seu funcionário e disse que este era um famoso coordenador de comitivas pantaneiras e, quem sabe, não estaria disposto a contar-nos sua história de vida. Cedeu-nos, então, o telefone do pantaneiro para que pudessemos entrar em contato.
} 
A gravação foi realizada na presença de sua esposa e transcorreu com muita tranqüilidade. Em alguns momentos, ele se emocionou ao lembrar de sua vida passada, principalmente ao lembrar dos pais e da avó que o criou. A gravação durou cerca de cinqüenta minutos, sendo que ele parou alguns segundos para se recompor, nos momentos de emoção, também neste caso fizemos poucas interferências e sua esposa acompanhou tranquilamente sem tecer comentários.

Os outros dois depoimentos foram gravados na Fazenda Santa Emília situada no Pantanal do Rio Negro, onde se desenvolve o turismo ${ }^{100}$, a pecuária e funciona uma Base de Pesquisa ${ }^{101}$ pantaneira. Os dois pantaneiros trabalham na fazenda, desempenhando a atividade pastoril e de turismo. R.O. é campeiro e, quando necessário, atende os turistas e A. trabalha como guia turístico e ajuda na lida do campo, quando não há turista na Pousada e precisam da sua ajuda (época de vacinação do gado, por exemplo). Além das atividades que desempenha $A$. forma, com outro peão da fazenda, uma dupla ${ }^{102}$ que compõe, toca e canta músicas pantaneiras.

O primeiro contato foi via telefone. Entramos em contato com o escritório da pousada em Campo Grande e conseguimos o telefone. Ligamos, mas não foi possível falar com eles, pois estavam trabalhando fora da sede. O gerente da pousada marcou conosco um horário em que com certeza seria possível encontrálos. Ligamos no horário combinado e conseguimos falar com eles, ficando agendada a conversa para o período em que os professores do Mestrado em Meio Ambiente da Universidade iriam, com seus orientandos, para realizar pesquisa de campo, assim iríamos no ônibus da Instituição.

\footnotetext{
${ }^{100}$ Na sede da fazenda funciona a Pousada Araraúna, criada para o desenvolvimento do turismo na região. A pousada possui instalações modernas, água, luz, telefone, redário (varanda própria para se armar várias redes ao mesmo tempo), sala de TV, pista para pousos e decolagens de aeronaves de pequeno porte. Estrutura para passeios de barco pelo Rio Negro e visita a outras fazendas, focagem de jacaré e passeios a cavalo.

${ }^{101}$ Essa fazenda compreende uma área que pertenceu a Fazenda Sta. Maria, que por sua vez foi desmembrada da Fazenda Olho D'água. Essa é configuração que se presentifica atualmente no Pantanal: a redução dos grandes latifúndios, que se deu primeiramente em função das divisões por herança. Esses herdeiros, criados nos grandes centros para estudar, não mantém a mesma relação que seus pais tiveram com a região e vendem suas terras a outras pessoas. A Fazenda Sta. Emília pertence a uma Universidade particular que construiu, no local, uma Base de Pesquisa pantaneira e uma Pousada. A Base está aberta a todo pesquisador que desejar desenvolver projetos de pesquisas sobre o Pantanal.

${ }^{102}$ A dupla já tem dois CDs gravados, recebe o incentivo dos donos da fazenda e Pousada e é uma das atrações para os turistas. À noite sempre tem roda de viola no redário, onde a dupla toca e canta para os visitantes, que acabam muitas vezes dançando até altas horas.
} 
$\mathrm{Na}$ data que havia sido combinada fomos até a fazenda ${ }^{103}$ para conversar com os pantaneiros, mas devido às atividades de atendimento aos turistas (a pousada estava com um movimento considerável naqueles dias), só foi possível ouvi-los em uma conversa coletiva ${ }^{104}$,em que os dois - além da conversa cantaram para todos os presentes. Um ano depois voltamos à pousada, novamente com os horários agendados e, desta vez, conseguimos conversar com os pantaneiros. Pedimo-lhes que marcassem o melhor horário e o local onde poderíamos conversar. R.O. pediu que fôssemos a sua casa, que fica dentro da pousada, no final da tarde daquele mesmo dia e A. preferiu conversar no dia seguinte, na sala de reuniões que, no período da manhã, não estaria sendo usada.

No fim da tarde, fomos à casa de R.O. - pantaneiro de 45 anos - que já nos esperava, sentado na varanda. Na pousada, as casas dos funcionários ficam na ala direita de quem chega e, quase todas, apresentam características semelhantes: são de madeira, pintadas, forradas, com energia elétrica, encanamento de água; são novas como tudo na pousada que foi inaugurada em novembro do ano 2000 . Pelo que foi possível observar a residência deste pantaneiro, que vive sozinho, é mais simples (não é pintada) e menor.

Explicamos-lhe a finalidade da nossa conversa, os objetivos do nosso trabalho e perguntamo-lhe se concordava em nos contar sua história de vida. Esclarecemos que a nossa conversa seria gravada, transcrita e faria parte do trabalho escrito que motivou a nossa visita. Respondeu-nos que estava a nossa disposição para conversar. Apresentamo-Ihe, então, o roteiro da nossa conversa, explicando cada um dos itens. Da mesma forma que na conversa com os outros pantaneiros, acrescentamos que aquele era só um roteiro para iniciar a conversa, e que ele ficasse à vontade para contar sua vida da maneira que desejasse. Igualmente, esclarecemos que não ficaríamos interrompendo a sua fala, pois queríamos ouvi-lo.

O pantaneiro mostrou-se tranqüilo durante a maior parte da narrativa, apresentando certo desconforto, expresso pelo sorriso nervoso, quando falou do

\footnotetext{
${ }^{103}$ A estada na fazenda/pousada durou três dias, nesse período visitamos também outras fazendas e contatamos com outros pantaneiros.

${ }^{104}$ Esse fato no período da noite. Gravamos essa narrativa da dupla de pantaneiros cantores que pouco falaram de suas vidas, concentrando-se na carreira artística e no Pantanal. Por isso não foram escolhidas para fazer parte deste corpus.
} 
casamento que não deu certo, do distanciamento dos filhos e do fato de viver sozinho. A gravação desta história (doravante D3) durou cerca de cinqüenta minutos, sendo que, em alguns segundos, ele parou para pensar e depois dar continuidade à história. Poucas foram as nossas interrupções.

No dia seguinte, fomos com A. para a sala de reuniões da pousada como havíamos combinado. $\mathrm{Na}$ tarde anterior, chegaram oito turistas argentinos à pousada e o pantaneiro perguntou-nos se dois deles, da área de comunicação, poderiam assistir nossa conversa, pois queriam saber mais sobre o Pantanal e pantaneiros para publicarem uma reportagem sobre o assunto, nos jornais em que trabalham. Falamos que, para nós, não havia problema. Reunidos todos na sala, procedemos aos encaminhamentos iniciais realizados com todos os outros pantaneiros com quem conversamos e já descritos nos relatos anteriores.

Este pantaneiro permaneceu bem à vontade durante toda a narrativa $e$ mostrou-se muito satisfeito ao contar que, aos 53 anos, voltou a estudar ${ }^{105}$. A gravação da história (doravante D4) durou cerca de cinqüenta minutos. Poucas foram as nossas interrupções.

Selecionamos quatro depoimentos por serem os que atendem aos objetivos propostos para este trabalho. Os outros, ou se enquadram no gênero entrevista, como já explicitamos, ou apresentam um conteúdo insuficiente para nossos propósitos. Entretanto, não estão descartados, pois constituem um excelente material para futuros estudos. Pretendemos voltar a eles brevemente, para novas pesquisas.

No tratamento do corpus optamos em considerar como a história de vida base para a análise do D1 complementada pelo D2, por serem as mais ligadas à tradição do passado; histórias de pantaneiros que trabalham e/ou trabalharam em fazendas nos moldes mais antigos; histórias que reportam ao passado, que evidenciam as muitas atividades dos peões pantaneiros, algumas que não são mais exercidas, outras que mostram como até o enfrentamento das enchentes - dadas as condições de vida e recursos - eram diferentes.

Os depoimentos D3 e D4 entram na análise como apoio e contraponto do atual em relação ao antigo. São depoimentos que refletem mais as atividades de

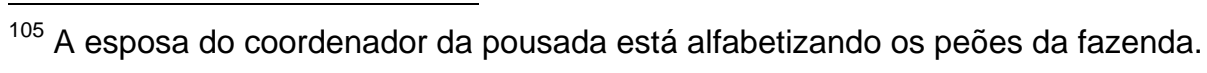


uma nova geração que está surgindo no Pantanal: a do ecoturismo. Estes pantaneiro viveram o antigo, conservam as funções tradicionais do Pantanal, mas assumem funções novas de guias turísticos, peões de pousada, motorista-safari, piloteiro, cantor de música pantaneira; são pantaneiros mais voltados para as atividades atuais, tendo em vista seu cotidiano e realidade profissional atual.

\subsubsection{O que dizem, como dizem e de que lugar dizem esses pantaneiros}

Tendo em vista que defendemos que o discurso do pantaneiro se presentifica nas histórias de vida do próprio pantaneiro, evidenciando, conseqüentemente, a imagem que esse pantaneiro faz dele mesmo, de seu cotidiano e a sua visão de mundo, passamos à análise do discurso desses sujeitos, onde buscamos as pistas que podem nos levar à confirmação dessa tese ou não.

Para tanto, consideramos, inicialmente, a afirmação de Possenti, explicitada anteriormente, no que diz respeito à relevância do interdiscurso, bem como a peculiaridade do tratamento das relações entre discurso e condições de produção, pensados a partir da Análise do Discurso francesa, e que estaremos considerando aqui.

A interdiscursividade como a propõe Maingueneau (2005, p. 33) se inscreve na perspectiva da heterogeneidade constitutiva da linguagem, a qual amarra, em uma relação indissolúvel, o Mesmo e seu Outro. No caso das histórias de vida, entendemos que essa relação se dá com o Outro contexto pantaneiro, com seu cotidiano e suas relações interpessoais, mas se dá também conosco, no momento da interlocução.

Essa relação Mesmo $X$ Outro que constitui o sujeito pantaneiro é aqui analisada, como dito anteriormente, num quadro que compreende, em particular, a interdiscursividade que remete a noções como heterogeneidade discursiva, sujeito e as condições de produção do discurso conforme formuladas por Osakabe, e os três eixos pensados por Geraldi no que diz respeito ao sujeito e suas ações. Procuramos detalhar abaixo esses três eixos que foram citados anteriormente, mas não explicitados. Estamos considerando que esses aspectos se entrecruzam e compreendem um todo no processo discursivo, portanto, no momento da análise não serão tratados separadamente, mas no contexto. 
O sujeito falante/escrevente, na interação com o outro, procede a escolhas dos recursos lingüísticos em que estão presentes tais ações. As ações que se realizam com a linguagem funcionam nessa interação como um jogo em que existem objetivos a serem alcançados: persuadir, informar, convencer, avaliar, seduzir, etc. Os interlocutores agem um sobre o outro a cada jogada. Como assegura Geraldi (1991, p. 27-8):

[...] as ações praticadas com a linguagem são, a cada passo, "ditadas" pelos objetivos pretendidos, o que pode levar um locutor a representar de modo distinto uma mesma realidade em função dos interlocutores a que dirige suas falas ou em função da ação que sobre eles pretende realizar. Dado que a fala se realiza entre os homens, as ações que com ela praticamos incidem sempre sobre $o$ outro, pois através delas representamos, e apresentamos a nossos interlocutores uma certa construção da realidade para com isso interferirmos sobre seus julgamentos, opiniões, preferências.

No caso dos pantaneiros, a imagem que têm de si mesmos, do seu cotidiano e do espaço pantaneiro, com certeza, é narrada de maneira diferente para esta interlocutora do que o seria para um amigo da região, a começar pelos objetivos da própria interlocutora, sua profissão, o nível de familiaridade, de conhecimento. Haja vista que todos eles, em um dado momento, falaram de estudos para dizer que estudaram pouco e/ou não estudaram e/ou para falar da preocupação com a formação dos filhos.

1. [..] ela esse ano ela fecha o ensino médio... né? aí ela já vai prestá:.: cursinho pra fazê o vestibular... aí ela vai segui o que ela... pretende sê né? mas por enquanto ela tá fechando o...: ensino médio do terceiro ano... agora.... esse ano ela... se ela não reprová ela... - - peço a Deus que não... né? que nunca reprovou - - ela fecha o terceiro ano... eu já também fiz de tudo na minha vida foi... foi... fui até balconista ( ) pra tê os filhos estudano... (D1 - linhas 440 a 446).

2. [...] porque lá no Pantanal é difícil escola... então... você não tem escola no Pantanal... né? se você tem um escola é até quarta série... aí da quarta série pra frente... você tem que saí... ou você deixa os filhos sem estudá... ou... muda do Pantanal... eu mudei... mudei pra mim podê dá estudo pros meus filhos... eu já num tenho... né? meu estudo é pouco... então... pra sê 
uma família de tudo analfabeto... (riu) achei que:: num compensava né? (D1 - linhas 446 a 453).

3. [...] tenho... é de formá meus filho.. (ah!) vou trabalhá pra podê formar (do jeito...) onde eles qué chegar... talvez num... num realize o meu sonho mas tenho essa vontade... se minha filha quisé... "vou sê veterinária" eu queria éh tê condições de fazer ela sê o que ela qué... tá entendeno? isso é meu sonho... né? (...) eu queria deixá eles formados... durante eu num formá eles... eu num tô sastifeito... eu num tô sastifeito... (D1 - linhas 493 a 504).

4. [...] a gente foi morá lá e lá a gente aprendeu de tudo... estudamo um pouco... (D2 - linhas 23 e 24).

5. [...] aí foi começando a vida e nóis/e nóis estudava... até o primeiro... segundo anos... éh... tinha o primeiro ano $A$ né? é... e o (segundo)/estudei muito poco... eu só escrevo o meu nome... mas eu conheço muita letra .... eu não sei é juntá... é formá as palavras... você sabe? (D3 - linhas 04 a 08).

6. [...] desde pequeno eu... passei a:: começá estudá... logo que eu me entendi por gente...né? comecei estudá... aí eu num levei a sério o estudo... (D4 - linhas de 02 a 04)

Em uma relação interdiscursiva, esse discurso apresenta algumas possibilidades de interpretação/efeito de sentido. Falando para uma interlocutora professora, esse pantaneiro-pai (exemplos 1, 2 e 3) mostra/denuncia o problema do ensino no Pantanal que reflete, na verdade, o problema do ensino em grande parte do meio rural deste país. Não existem escolas e se existem funcionam só até a quarta série, ou seja, as possibilidades de aprendizado oferecidas não chegam a uma formação profissional mais avançada.

Outra possibilidade de efeito de sentido tem relação com o discurso oficial sobre educação, profissionalização, valorização do ensino superior e sua relação com uma profissão/vida bem sucedida e melhores condições econômicas. Para esse pai, o sonho é ver seus filhos em uma condição melhor de vida, com uma profissão que não seja tão difícil, tão sacrificada como a dele. Ele não quer essa vida de peão para seus filhos. 
Um outro efeito de sentido possível é o de que esse pantaneiro faz um discurso para a interlocutora, com o objetivo de corresponder à expectativa desta, falando de um conhecimento que julga que ela domina e para mostrar que, embora não tenha estudado, valoriza o conhecimento. Seu discurso visa envolver a interlocutora, pois, por meio dele, o pantaneiro aproxima-a e aproxima-se nessa interlocução.

Em uma perspectiva da heterogeneidade constitutiva da linguagem é possível depreender no "não dito" o que se diz sobre questões como a evasão escolar e o êxodo rural.

Em relação à primeira, temos a dificuldade que encontram os filhos de pantaneiros de permanecerem nas cidades para estudarem. Como afirma 0 pantaneiro do D1:[..] aí da quarta série pra frente... você tem que saí... ou você deixa os filhos sem estudá..., ou seja, se o pantaneiro não tem onde deixar os filhos na cidade para estudar e/ou não tem condições financeiras de mantê-los, eles ficarão sem estudo e/ou terão de abandonar a escola.

Este fato se evidencia nos discursos dos exemplos 4, 5 em que os peões afirmam [...] estudei muito poco... (D3); [...] estudamo um pouco... (D2) e no exemplo 6 em que, mesmo procurando se responsabilizar por não ter prosseguido com os estudos [...] comecei estudá... aí eu num levei a sério o estudo.. (D4) o pantaneiro, com certeza, viveu situações semelhantes às dos outros peões por se tratar de uma questão social da região.

Em relação ao Pantanal, a segunda questão é, em parte, decorrente da primeira que configura a falta de escolas na região. O pantaneiro que deseja ver os filhos na escola tem de sair do Pantanal. E o que geralmente ocorre com esse pantaneiro? Vai viver na periferia de cidades como Corumbá, Aquidauana e Campo Grande em situação de pobreza, muitas vezes desempregado ou fazendo "bicos" e a esposa lavando roupa para ganhar algum dinheiro. Depois de ter trabalhado tanto, falta-lhe uma melhor qualidade de vida.

Bakhtin, conforme já explicitado no capítulo anterior, afirma que o fato de nos dirigirmos a alguém, a nossa relação com esse alguém, o intuito de dizer sobre determinado tema, leva- nos à escolha da(s) forma(s) típica(s) de dizer, ou seja, à 
estruturação do gênero discursivo mais pertinente ao contexto enunciativo, à esfera de atividade em que os falantes estão engajados.

Dessa maneira, podemos perceber que o estudo das ações que se fazem com a linguagem vai ressaltar que é por elas que as relações entre os interlocutores se modificam no processo. Conforme observa Geraldi (1991, p. 29), os estudos sobre a argumentação, principalmente os ligados à Retórica, vão evidenciar como, por meio desta, os sujeitos convertem o possível em necessário, o permitido em obrigatório, o inaceitável em aceitável.

No que diz respeito às ações que se fazem sobre a linguagem, Geraldi (1991, p. 41-43) estabelece algumas características, explicitando que para tal não se fundamenta em critérios rígidos, mas se dirige pela intuição. Para ele, há uma distinção entre as ações que se fazem com a linguagem e as que se fazem sobre a linguagem.

a) As duas ações são trabalho - trabalho em que, num processo interativo, o sujeito lança mão de recursos expressivos, por si sós, insuficientes à produção de sentido, aliando-os aos fatores extralingüísticos para que a compreensão se produza, produzindo um sentido, independente de ser este ou não o sentido construído pelo interlocutor. Como o diz Geraldi, [...] trata-se sempre de um sentido".

b) Essas ações, em sendo ações de sujeitos, compreendem sujeitos interlocutores. Aqui se dá, como observa o autor, a primeira distinção entre essas ações: as ações com a linguagem procuram deixar claro o tipo de ato que está sendo praticado, consideradas as condições de produção e os diferentes compromissos que se estabelecem entre os interlocutores a partir daí. As ações sobre a linguagem, por sua vez, têm como foco maior os recursos lingüísticos, sem deixar de lado os interlocutores e a produção de sentidos.

c) A ação sobre a linguagem, enquanto trabalho individual na produção de discursos, atua entre o estabilizado historicamente e o novo desse discurso; é o lugar da produção de novas determinações relativas à língua. As ações que se fazem com a linguagem também produzem determinações, porém estas são mais focadas no discurso que está sendo produzido.

d) A ação sobre a linguagem possibilita a ampliação do sistema de referências pela elaboração de novos modos de representação do mundo (note-se a 
importância das metáforas, dos raciocínios analógicos, das comparações, etc.) e [...] pela construção de sentidos novos mesmo para recursos gramaticalizados, atribuindo-lhes sentidos que, embora externos à gramática, são fundamentais enquanto "efeitos de sentido" no discurso.

Em sua participação nos processos interacionais, os sujeitos se constituem pelo trabalho lingüístico e nesse constituir-se existe uma ação da própria linguagem que se evidencia por meio das constrições precisamente lingüísticas e pelos sistemas de referências historicamente constituídos. Segundo Geraldi (1991, p. 51): [...] nascemos num mundo de discursos preexistentes e os sistemas de referências que eles revelam são incorporados pelo falante, constituindo, na expressão de Bakhtin, o material concreto da consciência dos sujeitos".

Dessa maneira, as ações da linguagem, seja em sentido estrito (interferência nas possibilidades de percepção e de raciocínio lingüístico-discursivo), seja em sentido amplo de construção de sistemas de referência (maneira de ver o mundo), restringem e estabilizam os modos de raciocínio e as formas de compreensão do mundo. Por outro lado, as ações com a linguagem e as ações sobre a linguagem buscam as possibilidades de irem além desses limites, presentificando-se mais uma vez a oscilação entre a estabilidade e a mudança.

Explicitados os aspectos que orientarão a análise, passamos à reflexão sobre as histórias selecionadas, considerando que no interior do capítulo estaremos reproduzindo trechos dessas histórias para os propósitos da análise. Os depoimentos se encontram, na íntegra, em anexo, no final deste trabalho.

Os resultados aqui apresentados refletem nosso "olhar" sobre essas histórias. Um olhar que - considerado o momento histórico e social que nos constitui, neste espaço/tempo - é um "dado olhar" em dadas condições de produção. Portanto, nesta análise procuramos levantar os aspectos que nos possibilitaram evidenciar as imagens que o pantaneiro tem de si mesmo, do seu cotidiano, sua visão de mundo - como vê a sua relação com o patrão e com os seus companheiros, qual é a importância de seu trabalho no contexto pantaneiro e como se sente vivendo no Pantanal. 
5.1.1.1 A caracterização do trabalho pantaneiro

Em análise do discurso, a questão semântica deve ser compreendida como efeito de sentido tendo em vista que os enunciados acontecem em determinadas condições de enunciação. ${ }^{106}$ Dessa maneira, para a análise do discurso o contexto histórico-social é fundamental na construção do sentido, permitindo-nos afirmar que toda aproximação de um texto ${ }^{107}$ coloca em pauta as suas condições de produção. Condições essas que se manifestam na interação, considerados os aspectos lingüísticos e os aspectos extralingüísticos, a partir do lugar que o sujeito ocupa e das imagens que constrói ao enunciar.

Considerando o lugar que ocupam, ao enunciar o seu discurso, os pantaneiros se colocam como trabalhadores do pantanal, evidenciando as diversas funções que desempenham. Todos os pantaneiros, ao narrar suas vidas, remetem ao trabalho, tanto às atividades que exerceram, como em relação às que realizam atualmente. $\mathrm{O}$ autor do D1 inicia seu discurso colocando o nome e logo em seguida já se apresenta como trabalhador do Pantanal.

1. [...] aí eu comecei a trabaia no Pantanal por volta de doze... doze ano... treze ano já comecei a trabaia no Pantanal... mas trabaiava em cima de::... da área de campero, né? (linhas 1-3)/ Aí eu larguei de trabaia no campo e passei a trabaia com trator... aí minha vida foi só trabaia no Pantanal com trator... éh::... [linhas 6 e 7].

O autor do D2 faz uma apresentação maior dele e da família para, logo depois, falar das funções que desempenhou no Pantanal:

\footnotetext{
${ }^{106}$ Enunciação aqui é entendida "... como um ato histórico e social. Portanto, não é independente de outras enunciações.[...]Uma enunciação não ocorre no vazio, mas em posições enunciativas prévias aos atos singulares de enunciação e são relativamente estáveis, embora historicamente mutáveis." Possenti, Sírio.Sobre a leitura: o que diz a Análise do Discurso?. In: Marinho, Marildes (Org.). Ler e Navegar -Espaços e Percursos da leitura. Campinas-SP: Mercado de letras: Associação de Leitura do Brasil - ALB, 200l.

${ }_{107}$ A noção de texto adotada é aquela postulada por Koch e Travaglia (1995), que consideram o texto como [...] uma unidade lingüística concreta (perceptível pela visão ou pela audição) que é tomada pelos usuários da língua (falante, escritor/ouvinte, leitor), em uma situação de interação comunicativa específica, como uma unidade de sentido e como preenchendo uma função comunicativa reconhecível e reconhecida, independentemente de sua extensão. A partir dessa noção e da noção de discurso, já explicitada, queremos deixar claro que não consideramos texto e discurso como sinônimos, pois o texto é a manifestação verbal do discurso, que é geralmente formado por uma pluralidade de textos.
} 
2. [...] desde dez anos... oito anos a gente trabalhô duro mesmo... fazia de tudo (na vida)... fomos casqueiro... naquela época tirava muita casca ...de madeira... de angico... pra vendê::...(linhas 16 a 19)/mudamos pra Miranda-Estância...(...) a gente foi morá lá e lá agente aprendeu de tudo...estudamo um pouco...eh:.: trabalhava... ajudante de bulicheiro ${ }^{108} \ldots$ de loja... bolicheiro... naquela época chamava bulicho... então agente era ajudante de bulicho... e estudava e trabalhava no campo... (linhas 21 a 27).

Esses dois pantaneiros trabalharam/trabalham em funções que compreendem as atividades sempre presentes na região pantaneira, em razão da principal atividade econômica ali desenvolvida: a criação de gado, bem como em razão da própria sobrevivência como poderemos constatar mais adiante.

Considerando esses aspectos, procuramos fazer, em primeiro lugar, uma apresentação das atividades desenvolvidas no Pantanal em uma tentativa de, a partir das histórias, mostrar o que é o trabalho pantaneiro.

A profissão de campeiro ou vaqueiro, por exemplo, foi e/ou é desempenhada pelos quatro autores das narrativas. Ela é definida como o trabalho com o gado, tanto no campo, quanto no mangueiro. Compreende as atividades de rodeio, de vacinação, de marcação, de cuidado com os bezerros recém-nascidos, busca de animais perdidos, de tratamento do animal machucado (ou doente, ou com bicheira).

3. [...] aí eu saio pro campo... aí vô pará rodeio no gado... vê se tem alguma rês abichada... se tem alguma rês doente ... então... esse é meu serviço..., [D3 - linhas 74 a 76].

O cuidado com os animais de montaria também é função do campeiro e inclui o tratamento de beleza.

4. eu vô ... casquiá um animal... fazê um jaravi no animal... casquiá o animal é a pata dele... você pega e levanta a mão dele... limpa por dentro... e aí tem ... um troques... aí corta o

\footnotetext{
${ }^{108}$ A atividade de ajudante de bolicheiro (o bolicho é um pequeno comércio semelhante ao que hoje chamamos de mercearia. O bolicheiro é aquela pessoa que atende os fregueses no bolicho) já não é mais comum no Pantanal, nos tempos atuais. Com a chegada da luz elétrica e, consequentemente da geladeira, bem como a maior facilidade de locomoção até a cidade mais próxima, possibilita a realização das compras nos supermercados dessas cidades.
} 
casco do animal... aí tem ali/tá até lá... ah:.: a grosa... aí já grosa bem::: dexa bem certinho... e o jaravi éh::: o rabo do animal... então cê vai tirá aquele mundo de... né? mundo de cabelo que fica... é mesma coisa que cortá cabelo... (risos) faz tudo isso... faz isso só quando cresce... é mesma coisa do cabelo... é a mesma... é a mesma coisa da unha nossa... quando cresce nóis tem que cortá porque senão ela vai ficando suja né? ${ }^{109}$ (D3 - linhas 78 a 87 ).

Esse profissional, entre outras características precisa ser um bom laçador, habilidade muito importante para um bom desempenho de seu trabalho. Um dado interessante em relação a esse profissional, como já referido anteriormente, é que todo campeiro que aparelha bem seu cavalo, ou seja, que tenha uma boa montaria, é considerado um bom partido para casar.

Ainda na lida com o gado e com os cavalos existem as funções de bagualeiro e domador, respectivamente. Esses profissionais são também campeiros, mas nem todo campeiro exerce estas funções. O bagualeiro vai atrás do gado alongado, selvagem, arisco que precisa ser integrado ao rebanho. Normalmente, este peão leva consigo um sinuelo (gado manso que se usa como guia para trazer os animais xucros de volta e conseguir amansá-los). Já o domador vai lidar com os cavalos que nunca foram montados, ou seja, vai torná-los mansos, prontos para a montaria. Segundo eles é um trabalho para peões determinados e dispostos.

5. [...] o pai foi um homem muito campeiro... muito laçador e disposto ele não tinha tempo ruim... era baguazeiro... gostava mesmo de trabalha... (D2 - linhas 189 a 181).

Há a atividade da condução das boiadas e os peões pantaneiros que realizam esse trabalho são chamados de boiadeiros, profissionais das comitivas que conduzem o gado que foi e/ou será comercializado, ou então aquela boiada que é transportada de uma fazenda para outra. De acordo com Nogueira (1989, p. 47-48) esta é uma atividade sempre executada pelos peões, sob o comando do capataz e a supervisão do proprietário.

\footnotetext{
${ }^{109}$ Grifos nossos.
} 
Além dessas profissões que existem até hoje no Pantanal, o ecoturismo surge como atividade econômica promissora para a região, trazendo novas profissões que, no caso do corpus em análise, está presente nos discursos daqueles já inseridos nessa nova atividade, os autores de D3 e D4:

6. [...] AGORA que eu vim pra cá que... eu tô mexendo com o negócio de turismo e... acho que tô indo bem né? (vai dando bem)... eu acho que eu tô tratando bem as pessoas que vem né? eu sei recebe eles... sei cunversá cum eles... (D3 - linhas 54 a 58).

7. [...] Fazenda Rio Negro - - que hoje lá é uma pousada... né?- - fui pra lá de pedrero... aí passei pra empresa pra trabalhá de... guia turismo... pra aprende... né? aí lá trabalhei dois anos de guia turístico lá... in:.:. aí fui convidado aqui na pousada... pra vim trabalhá também como guia turismo... vim pra cá... tô hoje com dois anos também... (D4 - linhas 65 a 70).

O guia turístico é o que acompanha os turistas nos passeios oferecidos pela pousada. Dentre eles estão os passeios de barco pelos rios, focagem de jacaré, passeios a cavalo e aos mirantes, além de outros passeios que o turista queira fazer.

A profissão de guia turístico tem, no mínimo, dois desdobramentos de função, que os pantaneiros qualificam de piloteiro e motorista-safari, sendo o primeiro aquele que, além de guia é também o piloteiro do barco que leva o turista e o segundo aquele desempenhado pelo motorista que dirige as toyotas com os turistas pelas águas (corixos, vasantes) e pelas estradas de chão.

Da mesma maneira que no caso do campeiro, o guia turístico pode ser ou não um piloteiro e/ou motorista-safari. Essas duas funções aparecem na entrevista coletiva que gravamos na primeira viagem que fizemos à pousada, na fala daquele que, nesta análise, é o autor do D4:

8. [...] então lá eu... passei a piloteiro lá... de barco... hoje eu tô aqui como piloteiro e... motorista... safári...110.

\footnotetext{
${ }^{110}$ Esta declaração do pantaneiro foi analisada no artigo Cotidiano e representação do pantaneiro nas narrativas orais, de autoria desta pesquisadora e publicado em ANASTÁCIO, E. B. DE A., MALHEIROS, M. R. T. e FIGLIOLINI. M. C. R. (Orgs.). Tendências Contemporâneas em Letras, Campo Grande: ed. UNIDERP, 2005, p. 267-278.
} 
Também a profissão de mecânico, ou seja, o que eles chamam de trabalhador com maquinário, surge no Pantanal no momento em que chegam os tratores, as caminhonetes, caminhões de pequeno porte, barcos e os carros que têm de ser consertados nas próprias fazendas/pousadas.

9. [...] voltei pra Aquidauana... fui aprendê trabalha cum maquinário... voltei pru Pantanal trabalhá... e tô até hoje... só que aí já passei a trabalha com maquinário... (D4 - linhas 59 a $62)$.

Ainda em relação ao lugar que ocupa o sujeito e o lugar que ocupam os interlocutores, o D1 é atravessado por um discurso, que explicita o aprendizado e a sua saída para outras atividades até chegar a uma formação melhor, inclusive uma posição de poder de decisão, a de encarregado das máquinas, ou seja, aquele responsável pelo bom funcionamento das máquinas e que tem o grupo de tratoristas e piloteiros de barco para coordenar.

10. [...] conforme a gente vem aprendeno de tratorista... então... você vai aprendeno... você vai aprendeno... você vai aprendeno e vai subino... né? vai subino... -- então na Caimã... eu já entrei como encarregado de máquina... daí eu comandava dezesseis tratorista... eu comandava lá... tudo éh:.... tudo era por minha conta... então... eu num precisava í no gerente pra saber se eles podia pegar um dia... se eles... precisava de um dia de forga... eles num precisava í no gerente... eles podia vim ni mim né? se eles precisasse dum dia... (D1 - linhas 223 a 230).

Tendo como interlocutora uma professora, que lida com a questão da aprendizagem, esse pantaneiro procura demonstrar que sabe a importância do aprendizado e credita seu crescimento e a sua competência como trabalhador, a essa busca pelo conhecimento.

Dentro dessa posição de poder de decisão estão, além do encarregado de maquinário, mas no mesmo patamar, a atividade de capataz de campo e o retireiro e, em escala maior, as funções de gerente e capataz de fazenda. O capataz de 
campo comanda as atividades dos campeiros e o retireiro é aquele que gerencia os retiros das grandes fazendas. Esses dois profissionais, por sua vez, recebem ordem e prestam contas ao capataz e lou ao gerente da fazenda. Atualmente, surge a figura do administrador que, em algumas fazendas, já está atuando no lugar de capatazes e gerentes, fato que se deve à transformação dessas fazendas em grandes empresas.

Vale ressaltar que nessa hierarquia está, em primeiro lugar, o patrão-dono da fazenda que se comunica, normalmente, só com o gerente e/ou capataz que, por sua vez, repassa as orientações e/ou ordens aos peões. No espaço de trocas - que constituem a interdiscursividade - e que se dá entre o discurso de autoridade do patrão e a prática do peão pantaneiro, está o capataz e/ou gerente que pode construir o seu próprio discurso de autoridade em relação a esses peões e suas práticas, que não vai ser aquele do patrão, mas um outro resultante das relações amistosas ou não com esses peões. Marca-se então como a figura de dominação nas relações de trabalho desse contexto.

11 .... aí tem que existir muita paciência... tranqüilidade... pra você consegui leva aquele que foi posto pra você até no destino final... né? tem que dá um jeito de se leva lá... então a gente:... cada lugar que a gente trabaia... em todas as fazendas... cada um gerente... cada um capataz tem seu modo de lidar... tá entendeno? aqui um lida dum jeito "ah... eu vou sai daqui porque o capataz é ruim" as vêis você vai prum outro lugar... é pior ainda... o capataz de lá é mais rígido... né? ele não gosta de brincadeira... ele quer as coisa certo... né? então você vai se habituano... a CAda tipo de fazenda é um tipo de... de mandato... né? cada tipo de fazenda... você trabaia com tipo de pessoa diferente... ocê tá entendeno? (D1 - linhas 167 a 178).

Possivelmente em decorrência disso, essas funções, que compreendem a parte administrativa das fazendas e pousadas e que implicam certo poder de decisão, são vistas pelos pantaneiros como funções de maior prestígio e compõem o que poderia ser chamado de "plano de carreira" desses peões. Aqueles que as desempenham usufruem de uma moradia diferenciada, bem mais confortável e situada próxima à sede da fazenda ou nas sedes dos retiros e não são mais chamados de peão. 
12. [...] eles prefere que você vai mais devagar... então tudo você vai aprendeno conforme os... os líder da cabeça... que é o capataz... se não tem o gerente é o capataz... se tem 0 gerente... primeiro é o gerente... (D1- linhas 181 a 184).

13. [...] conforme a gente vem aprendeno de tratorista... então... você vai aprendeno... você vai aprendeno... você vai aprendeno e vai subino... né? vai subino... -- então na Caimã... eu já entrei como encarregado de máquina... daí eu comandava dezesseis tratorista... eu comandava lá... (D1 linhas 223 a 226).

São funções, geralmente, destinadas aos casados:

14. [...] achei a dona A. ... namorei ela... e.. acabei casando... né?! e... aí a vida continuou... aí... daí já fui ser retireiro... já casei... já tinha mulhé... já podia ser retireiro... de fazenda... (D2 - linhas 50 a 53).

São profissões valorizadas:

15. [...] aí o E. me levou... pro Pequi... aí eu já fui ser capataz mais evoluído... né? mais... melhorado... ai passei a gerente... (D2 - linhas 71 a 73).

Constituem-se em metas dos pais em relação aos filhos que não quiseram ir para a cidade estudar.

16. [...] mas o C. não teve jeito de... de estudar... veio embora pra cá... eh... aqui eu ajudei ele a comprar uns tratores e foi começá a formá pasto pros outros... cem hectares... né?... assim... com grade... etc e tal... aí:: eu achava que não tava bem... que ele tinha que ser gerente... capataz de alguma faZENda... (D2 - linhas 138 a 143).

Ao narrar as atividades que vivenciaram/vivenciam esses pantaneiros narram - a alguém que desconhece totalmente a realidade desse tipo de atividade 
e do contexto pantaneiro - sua vida de trabalho no Pantanal, caracterizando-o por meio das dificuldades, ou seja, é bom viver no Pantanal, mas não é fácil. $O$ trabalho é difícil e essa dificuldade decorre de alguns aspectos evidenciados no discurso como, por exemplo, o tipo de atividade, as possibilidades de locomoção, as distâncias e os fenômenos da natureza.

O trabalho diretamente com o gado (vaqueiro, campeiro, bagualeiro, domador) e com trator destaca-se como mais difícil.

17. [...] aí eu larguei de trabaia no campo e passei a trabaia com trator... aí minha vida foi só trabaia no Pantanal com trator... éh..... puxá CARga... levá CARga... duma fazenda pra otra... as vêis... a gente trabaiava o dono da fazenda tinha duas... três fazenda... então... a gente tinha que locomove de uma pras otra pra levar CARga, né? são mantiMENto... as vêis arame... éh material... que as vêis tava construindo e a gente tinha que levar... e daí que a gente começava a sofrer MAIS que a vida de campero... que as vêis a gente achava que a vida de tratorista era mais fácil e não era... era mais difícil... mais difícil porque a cavalo você não atola e com trator você atola... né? com trator você atola e as vêis fica o dia inteiro... a noite inteira com ele ali... sem poder sair... (D1 - linhas 06 a 17)

18. [...] tive uns três anos sozinho... só eu e a A. ... recebi um gado pra cuidar... um plantel de gadu Gír.. então... eu fazia tudo... eu era retireiro... era pião... era capataz... era tudo... fazia todo o serviço da fazenda... certo?... e o meu tio era o gerente da fazenda... ele me deu uma égua velha e um burro aporriado e dez éguas pra mim adomá se eu quisesse andá a cavalo... bem a cavalo e eu domava e a dona A. me ajudava... ela.. segurava... eu montava... então nós só (tossiu).. a gente pedia a Deus pra ajudá pra não acontece nada... (D2 - linhas 60 a 68).

19. [...] o meu pai trabalhando de charretero e ... ele só tinha um lado da perna dele... ele quebrou a perna ali na fazenda Jurumi... ele tinha dezenove anu... mas nem... trabalhando nu campo... um touro trompo na perna dele.... e quebrô... (D3 linhas 09 a 13).

20. [...] e continuei a vida no campo de novo... de campero... aí levei uma (rodada) se quebrei tudo... quase morri... foi/fiquei vinte e quatro hora desacordado... essa é uma das dificuldade e o perigo que a/o campero passa... igual... tem o Seu R. 
aqui... que trabalha conosco aqui... que toma conta do gado... então ele éh:.. o trab... o trabalho dele é arriscado... que no momento que ele tá correndo atrás duma (vaca) ele pode levá uma rodada... sozinho... se quebrá ou enganchá no (arreio) sair dipindurado sozinho... aí vai... vai a morte... né? (D4 - linhas 37 a 45).

Além do perigo de acidente para o peão, quem desenvolve essas atividades enfrenta os problemas de locomoção em razão das distâncias, da amplidão que caracteriza normalmente as fazendas pantaneiras e do inevitável enfrentamento com os fenômenos da natureza e com os animais.

21. [...] as distâncias são muito grande... você teje de a pé... você teje de a cavalo... você teje em cima de um trator... tudo é longe... tudo é longe (disso aí)... né? (D1 - linhas 28 a 30).

22. [...] você vai dum retiro... você sai da sede pra ir num retiro vinte quilômetro... né? se tá na seca você faz ele com duas hora... se tá na época das águas... você vai fazer aí... o dia inteiro e ás vêis não chega... você atola... você desatola... você atola e vai indo até você chegá no seu destino final... né? então... é por isso que eu falo que é difícil... então... as coisa lá não é fácil... (D1 - linhas 34 a 40).

23. [...] éh:... você não SERve... porque você vai leva uma carga... principalmente de uma fazenda pra otra... hoje chegou a compra do mês... aí eles põem você pra levá essa compra lá num retiro... cinqüenta quilômetros... lá no retiro... as pessoas de lá num tinham mais nada o que cumê... já tinha acabado... então aquela compra tem que chegar LÁ... aí você atola o trator... fica nervoso... volta pra trás... aquela compra vai chegar lá em três quatro dia... qué dizer que você não tá sofrendo... quem tá sofrendo é os otro que tá sem nada lá... (D1 - linhas 159 a 167).

24. [...] aí mudamos pra fazenda ( )... mudamos pra fazenda Divisa... que ele comprou no pantanal lá do outro lado do Rio Negro e enchia demais... naquelas épocas... enchia MUlto... em cinqüenta e quatro mais ou menos... enchia demais... (nóis) levemos... uns sessenta dias pra saí daqui... de...de... da Vasante... pra chegá nessa fazenda Divisa... e tinha que atravessá o Rio Negro... o rio Aquidauana e tudo tava cheio... 
então parava... dez dias... cinco dias esperá rio baixá ... córgo abaixá ... co... corixo... né? (D2 - linhas 38 a 45).

25. [...] é gado por exemplo... você precisa de mata um gado no frigorífico aqui... você ... tando cheio... num tando cheio... tinha que vim... então... era uma... um dos sustos que a gente sempre passava... você nadando com o gado... aquilo é um perigo... nadando... né? o rio negro quando enche ele emenda com o aquidauana e vem até aqui na... na... na Costa Rica... aquilo é um mar só de água... e nada de tê curixo... nada... a gente vinha/fazia pelota das... das mala... pra num... num... num rodá... fazia aquela pelota... amarrava na garupa... trazia ela... dava um jeito de trazê... pra num se molhá todo... até a roupa né? enrolava num plástico... numa capa... num negócio e vinha nadando... deixava um pouco do pelego... vinha só com um peleguinho... éh... éh era dificultoso... não era fácil não... (D2 - linhas 337 a 349).

26. [...] o velho meu pai... a gente vinha... ele era o cacique... era o... o patrão do negócio... né? então... a gente vinha com ele... fazia o bota fora dele até um ponto determinado... assim que não tinha perigo mais pra frente... vinha... sempre era eu... eu era o mais velho dos irmão... né? eu vinha... eu ou o outro irmão ou um peão bom... fazia bota fora dele... atravessá aqueles curixo... aquelas vasantes... nadando... bola à pé e tal... atravessá o rio negro... a barra... largava ele aqui na Costa Rica... ele vinha pra Aquidauana... né? no caso de precisão... aí... ele largava o animal dele... em qualquer lugar do retirinho... -- por exemplo -- era um ponto de referência... aí... depois a gente pegava o animal... ou ele ia de condução ou chegava até Aquidauana de a cavalo... né? se ali já... aí nu retirinho sempre já tinha mais facilidade... ali já... a condução de vez enquando já vinha... o senhor S. P. tinha sempre um carro... (D2 - linhas 322 a 336).

27. [...] e fora os risco... também que eu passei antes de... (disso) passei muito risco com onça... né? éh:.: viajando à noite... cavalo pulá comigo... me derrubá... e eu ficá de a pé no meio de onça... passá aquele (D4 - linhas 82 a 85).

28. [...] pra onde eu cheguei hoje... eu passei por muita dificuldade dentro do Pantanal... que antigamente era muito difícil... pra... pru senhores vê... antigamente não existia condução... a condução nossa no Pantanal era carreta de boi que era (cangado)... do Pantanal a Aquidauana nóis gastava uma semana viajando.... éh:: naquele batidão... devagazinho... então era uma semana de viagem pra ir já... ia base de:: oito... 
dez carreta em (cordoadas)... ia fazê a compra... pra... passá o ano.... era compra de ano... então... eles gastava semana enjoava de andá em cima da carreta ía de a pé... burro de carga... ou ( ) aí montava de novo... í:... só água naquele mundo... (D4 - linhas 86 a 96).

Ao narrar o cotidiano que os constitui, esses pantaneiros, não só se colocam como trabalhadores do Pantanal, mas em sua "arte de fazer" mostram-se também solidários, hospitaleiros, donos de um espírito comunitário e itinerantes.

A mobilidade desses peões é uma característica muito antiga no Pantanal e sua raiz possivelmente esteja ligada aos primeiros moradores da região como os gaúchos, cujos costumes fazem parte da cultura pantaneira, dentre eles o mate ou chimarrão, por exemplo.

29. [...] minha vó era uma gaúcha MUlto trabalhadeira... MUlto dinâmica...juntô todo mundo num lugar só... aprendemos muita coisa com ela... ajudávamos ela fazer flores (sabe?)... pra podê ganhá o pão... (e) teve muito ajutório... do Cel. Z. (esse povo antigo aqui) ajudou muito ela porque eles eram do Rio Grande... né?... então:... eles ajudaram muito a gente...e.(D2 07 a 12).

30. [...] éh... éh:..... depois você conta no galpão... hora que você vai tomá mate de madrugada ou então de noite... depois da janta... a pessoa tá desinciliando o cavalo... e tal... tá contando as histórias... "poxa...você viu aquela hora que afundo... fulano saiu lá na frente... né? aquele boi que ia rodando... se viu o J. saiu nele lá e ... pegô o boi... fez o boi voltá na/no gado" (D2 - 358 a 363).

31. [...] então... eu levanto cedo... tomo meu mate aqui... naquele fogãozinho ali... cedo só eu... e Deus né? (D3 - linhas 67 a 68).

Entretanto, essa mobilidade, principalmente hoje, é muito forte em razão das condições de trabalho. Na esperança de encontrar um trabalho que thes ofereça melhores condições de vida, vão mudando, muitas vezes por informações dos 
amigos sobre um determinado fazendeiro ${ }^{111}$ que paga melhor, oferece melhores condições de trabalho, de moradia e, dessa maneira, tornam-se itinerantes, não se enraízem em lugar algum.

32. [...] na Caimã que eu fiquei cinco ano e meio....(D1 - linha 222).

33. [...] de lá eu vim pra fazenda Estrela... aí pra... aí já foi em cima da (serra)... vim pra fazenda Estrela só que daí eu num era mais o encarregado.... eu já vim ser subordinado... né? eu já fui sê pião... lá já era outro encarregado que mandava ni mim... aí que trabaiei três anos e meio lá... aí eles venderam a fazenda e eu vim pará hoje aqui... na Paloma. ( ) um ano e seis mês... já fez que eu tô aqui na Paloma... fez um ano e seis mês... (D1 - linhas 240 a 247).

34. [...] oitenta e cinco eu casei... casei em Aquidauana e trabaiava em... em :.:cento e dezoito quilômetro na fazenda Paiaguás... cento e dezoito quilômetro no Pantanal... na fazenda Paiaguás... (D1 - linhas 403 a 405).

35. [...] aí eu fui pro norte de Mato Grosso... lá pra lá de Coxim... pro Pantanal também... (D1 - linhas 418 a 419).

36. [...] graças a Deus consegui a fazenda... que foi aí... pertinho de:.: de Campo Grande... então tinha condução que levava até Campo Grande e trazia até a fazenda.... (D1 - linhas 464 a 466).

37. [...] mudamos pra Miranda-Estância... meu pai foi sê gerente na Miranda-Estância na época de Dom R. ... que era Companhia Inglesa... né? (D2 - linhas 21 e 23).

\footnotetext{
${ }^{111}$ Atualmente existe muita diferença no tratamento com os peões, por parte dos patrões. Existem os que oferecem boa casa, que fornecem a carne de graça, os alimentos, mas há os que não dão nada além do pequeno salário e um lugar, nem sempre confortável, para morar. Antigamente, as relações eram mais próximas. Muitos patrões trabalhavam, lado a lado, com os empregados na época da instalação das primeiras fazendas. Naquele tempo era comum os proprietários terem o mesmo grau de instrução dos empregados e hábitos e costumes semelhantes, visto que provinham de ambientes igualmente humildes. Essa situação assegurava uma interação entre patrão e peão, que mantinham laços de cordialidade e amizade, consolidados, muitas vezes, pelas relações de compadresco. Conforme Nogueira, Albana Xavier. A linguagem do homem pantaneiro. Assis-SP: UNESP, 1989 (tese de Doutorado)
} 
38. P[...] da fazenda Miranda-Estância para a Vazante... onde estivemos uns quatro anos também... (D2 - linhas 30 e 31).

39. [...] eu morei muitos ano no Pantanal... toda vida fui do Pantanal... todas as fazendas... Fazenda Divisa... Fazenda São José... Rio Negro... (D2 - linhas 172 a 174).

40. [...] aqui vô fazê quatro mês... vim agora há pouco... eu vim em três mesmo... eu vim com a... a R. ... senhora conhece a R.? a R. que eu vim...ela é diarista aqui... a gente veio pegá uns porco aí... eu fique uns quatro dia diaristando com ela aqui... aí... aí que surgiu essa vaga pra mim aqui... né? aí eu fiquei aqui... aí o patrão chegô e o N. falô com ele sobre mim... né? (D3 - linhas 309 a 315).

Nessa vida itinerante, em interação com outros sujeitos e no espaço/tempo de um contexto maior, constroem um espaço de solidariedade, espírito comunitário e hospitalidade.

41. [...] são as pessoas... tudo quanto éh lugar que você chegá... você é bem tratado... tudo lugá que você chegá... você é bem tratado...(...) cedem a comida... se você chegá numa casa dum pantaneiro... a primeira coisa que ele pergunta pra você "você já comeu? você já armoçou? você quer tomar um tereré?" ele qué sê/ele qué fazê você feLIZ... aquilo ali pra ele éh um prazer... né? (D1 - linhas 305 a 311).

42. [...] então... todo lugar que você chega lá... você tem (esse espírito)... você tem (esse espírito)... e o que eles pode cede pra você... eles cede... se você tá indo de a pé... eles te dão um cavalo... se tive um trator "não... pega fulano... leva lá na fazenda" eles manda leva... então éh diferente de outros lugar.... (D1 - linhas 321 a 325).

43. [...] se precisá hoje... dum trator pra í trabaia numa fazenda vizinha... o fazendeiro "oh... vai lá e trabaia o dia inteiro pra lá" "quanto custa?" "num custa nada" porque amanhã... ele vai... talvez ele vai precisá daquela fazenda... que você prestou um dia serviço pra ele... trabaia pra ele também... então... eles chamam... né? então chama... "você vem... trabaia" num custa nada... né? num custa nada... então você sai... fica as vêis quatro dias na otra fazenda... você não vai pagá cama... você não vai pagá comida... você não vai 
pagá nada... se você precisa í naquela fazenda... vai acontece a mesma coisa com você... (D1 - 337 a 347).

44. [...] e no pantanal... as vêis... se uma pessoa anda aí... levando um trator que quebrou aí... as vêis... trinta... quarenta quilômetro... quanto custa isso? num custa nada... por quê? porque ele faz pra você hoje... amanhã você faz pra ele... então... são trocado... isso é trocado... né? ninguém cobra nada de ninguém... pra otro lugar que você fizer isso... eles só faz em cima de dinheiro... só em cima de dinheiro... (D1 linhas 329 a 335).

45. [...] o pantaneiro é um povo muito acolhedor... muito bom... você chega numa fazenda no Pantanal você tem tudo... era assim né? (D2 - 188 a 189).

Da mesma maneira que o trabalho, o lazer também é difícil. As grandes distâncias e os meios de locomoção dificultam as saídas, especialmente dos casais, para festas em outras fazendas. O lazer fica mais para os solteiros que têm mais facilidade de sair.

46. [...] ah... tá tudo parado... vamos lá na fazenda... fazenda fulana lá brinca" de que que eles vai brincá? vai lá conversar... diverti... você tá entendeno? então... as vêis lá na... - - aqui nóis somo quatro pião... lá éh mais três - - então num tem como você fazer um divertimento... um jogo de bola... com sete pessoa né? você vai lá... mas só conversá e falá das coisa... que você mesmo fez... ah... eu lacei uma vaca... eu atolei o trator... eu... eu montei num bezerro... eu... eu brinquei... montei num cavalo... então esse aí é o divertimento deles... (D1 linhas 252 a 260).

47. [...] que as vêis... onde vai ter aquela festa... éh:.... carro num vai... só vai a cavalo... como é que um pai de família vai as vêis com três crianças... muié... tudo em lombo de cavalo... né? então... os rapaz sortero se locomove com mais facilidade... porque ele é sozinho... né? ele pega uma muda de roupa... ponha num ( ) dele... ele vai com a roupa suja... chega lá ele toma banho... troca de roupa... no outro dia ele pega o caminho e vem embora... então... mais éh sortero... mais éh sorTEro... só participa mais os casado... éh... quando a festa éh na fazenda que você mora... aí os casados participa... (D1 - linhas 265 a 274). 
Os casais têm sua oportunidade de lazer, como colocou o pantaneiro da N1, nas festas que acontecem na própria fazenda onde trabalham. Essas festas são, geralmente, festas de santo, o santo protetor daquela fazenda ou o santo de devoção do fazendeiro. Além dessas festas, pouquíssimas são as possibilidades de lazer do peão e sua família.

Esse trabalhador itinerante, que em muitos casos não tem um espaço próprio para morar, que não tem tempo e/ou condições de lazer nem para si, nem para a família, que trabalha duro e gosta do Pantanal, nos fala da construção/constituição de um "aprender" pantaneiro.

\subsubsection{Uma pedagogia pantaneira ou o aprender a ser pantaneiro}

O autor do D1 fala do lugar de alguém que viveu no Pantanal, ou seja, ele nasceu e viveu trabalhando no chamado baixo Pantanal, mas atualmente vive e atua no alto Pantanal (para usar a expressão deles: no "alto da serra"). Muito embora esses espaços mantenham características geográficas distintas, compõem 0 contexto mais amplo da Bacia do Pantanal. Considerando a afirmação de Bakhtin (1986, p. 121) de que

[...] a enunciação enquanto tal é um puro produto da interação social, quer se trate de um ato de fala determinado pela situação imediata ou pelo contexto mais amplo que constitui o conjunto das condições de vida de uma determinada comunidade lingüística;

este pantaneiro, fala de um aprender a ser pantaneiro ou, poderíamos dizer, de uma pedagogia pantaneira. Utilizando-se de recursos lingüísticos característicos da oralidade como as repetições, das referências dêiticas as quais levam em conta as unidades internas do discurso, bem como as que lhe são exteriores $e$ compreendem a situação de comunicação, de metáforas e do uso do gerúndio, evidencia no seu discurso que se aprende a fazer fazendo. $O$ aprendizado está presente também no D2 e D4.

Benveniste (1991, p. 277-283), ao tratar da referência dêitica, define-a como [...] um conjunto de signos "vazios", não referenciais com relação à "realidade", 
sempre disponíveis, e que se tornam "plenos" assim que um locutor os assume em cada instância do seu discurso. Os dêiticos são - dentre os componentes que compõem a estrutura do enunciado - aqueles que, por excelência, instauram a subjetividade na linguagem. Eles compreendem tanto os índices de pessoa (a relação eu-tu) quanto os índices de ostensão (este, aqui, entre outros) (BENVENISTE, 1989, p. 84-85).

No exemplo 01, temos o advérbio lá que exerce a função dêitica de mostrar o espaço do trabalho, neste caso, o trabalho do campeiro/vaqueiro.

1. [...] você num sabe trabaia... então... você vai aprende oiando os zotro fazê... conforme o zotro vai fazeno... então... o própio capataz... que (fala) que é da fazenda... ele apóia você... "vai lá... joga o laço... laça... pega... maneia né?" pra você í aprendeno... então você já aprende trabalhano... você já aprende trabaLHANO... aprende fazê tudo... (D1 - linhas 100 a 105).

É a voz do outro - que ensina e incentiva ao aprendizado - presente por meio da heterogeneidade mostrada e marcada, na fala do capataz: [...] vai lá... joga o laço... laça... pega... maneia né?", ou seja, comece a fazer que você aprende; é lá, na própria lida, o lugar do aprendizado.

2. [...] mudamos pra Miranda-Estância... meu pai foi sê gerente na Miranda-Estância na época de Dom R. ... que era Companhia Inglesa... né?! a gente foi morá lá e lá a gente aprendeu de tudo...estudamô um pouco...eh::: trabalhava... ajudante de bulicheiro, de loja... bolicheiro, naquela época chama bulicho... então a gente era ajudante de bulicho... e estudava e trabalhava no campo... era campero também.(D2 linhas 24 a 27).

No segundo exemplo, o advérbio lá exerce uma função diferente da anterior. Não se trata de um dêitico, mas de uma referência anafórica, pois faz referência à fazenda em que o pantaneiro estava morando. Possenti (200?) em seu artigo Duas notas sobre pronomes ${ }^{112}$ afirma que [...] pronomes como ele, toda a série dos

\footnotetext{
${ }^{112}$ Esse artigo pode ser encontrado no site iwwww.primapágina.com
} 
demonstrativos e mesmo advérbios e locuções como (este, esse, aquele, assim, aí, lá etc.) podem ter um funcionamento dêitico e outro a que os lingüistas chamam de anafórico".

O anafórico lá, neste caso, possibilita mais de uma interpretação. Ao dizer que [...] lá a gente aprendeu de tudo... o pantaneiro não só oportuniza a construção de sentido de que no Pantanal se aprende a fazer fazendo, mas também o sentido de que, especificamente, naquela fazenda se tem a oportunidade de aprende a fazer tudo. A fazenda referida é uma grande empresa que atualmente chama-se Fazenda Kaimã e todos os pantaneiros citaram-na como local de trabalho, pois trabalhar lá é referência para os peões.

A repetição é outro recurso lingüístico que permeia as histórias dos pantaneiros. Diferentemente de sua ocorrência na escrita, onde não é muito prestigiada, a repetição, no texto oral, é uma das estratégias básicas de construção/formulação do discurso, conforme observam Koch (2002, p. 118) e Marcuschi (2002, p. 105). Como observa Marcuschi (2002, p. 105), a repetição, por sua flexibilidade funcional, desempenha uma variedade de funções: Para o autor ela "contribui para a organização discursiva e a monitoração da coerência textual; favorece a coesão e a geração de seqüências mais compreensíveis; dá continuidade à organização tópica e auxilia nas atividades interativas. Com isso, faz-se essencial em uma gramática da textualização na língua falada, dando maior leveza ao texto e possibilitando um maior envolvimento interpessoal".

Seus efeitos semânticos apresentam uma classificação bem variada no campo da semântica e da estilística, mas, segundo Koch (2002, p. 124) nas interações face a face, evidenciam-se alguns tipos de auto-repetição peculiares, sempre com funções que exprimem algum tipo de intensificação como, por exemplo: empatia, insistência, pedido de confirmação, ameaça (caso de repetição do verbo no final de interrogativas), reduplicação de um item explícito no contexto imediatamente anterior, repetição do verbo acompanhado de mesmo exprimindo dúvida sobre algo que o locutor julga difícil acreditar ou pedido de confirmação de alguma coisa que deseja intensamente etc.

A repetição, do ponto de vista das funções, vai atuar em dois planos. O primeiro deles é o plano da composição do texto que compreende o texto em sua materialidade e na seqüência das cadeias lingüísticas. Nesse campo, a repetição 
incide na função básica de coesividade. O outro é o plano discursivo com característica mais global relacionado aos aspectos interacionais, cognitivos e pragmáticos. Neste caso, a repetição desempenha um maior número de funções, contribuindo para a compreensão, a continuidade tópica, a argumentatividade e a interatividade (MARCUSCHI, 2002, p. 117).

O autor observa que normalmente todos nós "admitimos que repetir é produzir o mesmo segmento lingüístico duas ou mais vezes, mas que a repetição não é um simples ato de metalinguagem, pois ela expressa algo novo". Existe muita diferença entre repetir elementos lingüísticos e repetir o mesmo conteúdo. Portanto, usar da repetição das mesmas palavras em um discurso, nem sempre equivale a dizer a mesma coisa.

Nos exemplos a seguir, a construção do sentido de que, no Pantanal, se aprende a fazer fazendo se dá pela repetição de verbos, especialmente os verbos aprender, trabalhar e fazer na função de intensificação/esclarecimento ou de argumentatividade/reafirmação. Os pantaneiros usam o recurso da repetição com a finalidade de esclarecer como se aprende as atividades pantaneiras ou evidenciar o seu desejo de aprendê-las, como podemos ver na expressão [...] porque eu queria aprender trabalhá e aprender... no exemplo 03.

Por outro lado, é possível depreender do discurso que eles queiram, com o uso desse recurso, reafirmar a dificuldade do aprendizado e assim valorizá-lo diante de seu interlocutor ou argumentar que é difícil esse apredizado, como nos mostra o exemplo 04. O campeiro [...] aprende tudo que é feito... em cima do campo.../ aprende tudo... então nada éh fácil pra ele... né? ele mesmo faz a traia dele...

3. [...] porque eu queria aprender trabalhá e aprender... né? então aí eu comecei com ferramenta... aí passei muntá a cavalo... meu tio era muito rígido então... (hoje) a primera vêis num ( )... muntei... caí... ele me deu um (laçaço) fez eu muntá de novo - - que era rígido antigamente... a coisa era diferente mesmo... do que vê hoje... né ?- - mais então... amuntei... aí foi ino... após uma semana já comecei pará em cima do lombo do animal... foi ino... foi ino... foi ino... que eu gostei... né? (D4 linhas 14 a 21).

4. [...] se aprende tudo que é feito... em cima do campo... é os própios campeiro que faz... ele aprende faze um (arreio)... aprende trança o laço... aprende fazê um:... ( )... aprende 
tudo... então nada éh fácil pra ele... né? ele mesmo faz a traia dele... (D1 - linhas 105 a 109).

Ainda no exemplo 03 , temos também a repetição do verbo montar, que mostra a insistência do pantaneiro nesse aprendizado fundamental para 0 desenvolvimento do seu fazer. Ele foi aprender a montar e passou dificuldades; caiu, apanhou porque não parou no lombo do cavalo, montou novamente, levou uma semana para parar em cima do cavalo, ou seja, é intensa a sua luta para aprender a montar.

A repetição da locução verbal com o verbo principal no gerúndio é bem significativa nas histórias dos pantaneiros. Segundo Possenti (2004, p. 27), o gerúndio pode ocorrer em três situações: a) quando o sentido denota uma ação progressiva; b) quando uma oração tem dois predicados e c) quando se trata das orações reduzidas de gerúndio. No caso das histórias dos pantaneiros, as locuções de gerúndio produzem um efeito de sentido de uma ação progressiva, isto é, além do efeito de intensificação/continuidade causado pela repetição, a ação do aprender, neste caso, é uma ação que não ocorre de imediato, ela é um processo gradativo.

Algumas expressões nos possibilitam compreender isso: [...] aí foi ino... após uma semana já comecei pará em cima do lombo do animal... foi ino... foi ino... foi ino... que eu gostei... (exemplo 3). Neste caso, a ação progressiva é seguida de uma avaliação do pantaneiro. A situação inicial do aprendizado foi sofrida e pelo que ele diz e como diz podemos inferir que no início não havia gostado "foi ino... que eu gostei”.

5. [...] se você... vai aprende trabaia com trator... se eu com treze... dezessete ano... eu num saBIA... então o que eu ia sê? ia trabaia de ajuDANte... você começa trabaia de ajudante daquele tratorista... você tá entendeno? ai você vai trabaiando de ajudante... aí você vai oiano ele... ele trabaia... mudá marcha... pára... sai né? aí você pede pra ele "deixa eu leva um pouquinho?" então você vai pegá... como você vai pegá? você vai pegar nos lugar bom... porque se ele te dé num luga ruim... ocê vai ficar ruim... vai ser pra ele... porque você vai atola... vai fica mais difícil... então depois que você aprende nos lugar bom... aí você começa a:... dirigir também nos lugar difícil... pra vê se você tem capacidade de fazê o serviço que ele fez... linhas 109 a 120. 
$\mathrm{Na}$ expressão [...] ai você vai trabaiando de ajudante... aí você vai oiano ele... ele trabaia... mudá marcha... pára... sai né? aí você pede pra ele "deixa eu leva um pouquinho?" então você vai pegá... como você vai pegá? você vai pegar nos lugar bom... porque se ele te dé num luga... (exemplo 5) o sentido de processo gradativo se constrói por meio da intensificação/ continuidade que avança detalhando os passos/etapas do processo de aprendizagem, como observamos nos exemplos 3 , 4 e 5 acima.

No exemplo 5, o pantaneiro lança dois questionamentos que ele mesmo responde no interior da sua própria fala: [...] eu com treze... dezessete ano... eu num saBIA... então o que eu ia sê?/[...] então você vai pegá... como você vai pegá?. É possível afirmar que esta é uma situação em que temos um discurso imaginário, em que o pantaneiro pergunta e responde no interior de sua própria fala. $\mathrm{O}$ fio do discurso é interrompido, do ponto de vista da linearidade com o intuito de explicar detalhadamente quais são as etapas do aprendizado com trator.

6. [...] então você já aprende sofrendo... você já aprende trabaiando em cima daquilo ali que você aprende... né? então hoje... você passa num lugar difícil... passou bem... quando é amanhã... ele já não tem medo de te entregar o trator pra você í sozinho... porque sabe que você vai e VOLta... uma atolada... duas atolada... não vai deixar o trator na estrada... você vai vim com ele... você vai desatolar... ocê vai sofrê até você voltar aquele trator pra trás...120 a 126.

7. [...] você se vira... porque todas as vezes que cai numa dificuldade... e o próprio cara que é profissional... tira você... você jamais vai aprende... tá entendeno? então ele vai 'NÃO... voCÊ tem que fazê assim"... ah mais... não... "faz assim que você vai sai daí" tá entendeno? agora se ele fizer... você não tá aprendeno... né? então... ele vai deixá você sofre um pouco... que é pra você aprende... linhas 128 a 134.

Nos exemplos 6 e 7, o efeito de sentido é de que aprender é sofrer. Esse sentido acha-se explicitado nas expressões [...] então você já aprende sofrendo... você já aprende trabaiando em cima daquilo ali que você aprende... (exemplo 6)/ [...] você não tá aprendeno... né? então... ele vai deixá você sofre um pouco... que é pra 
você aprende... (exemplo 7). A idéia é a de que aprender fazendo é uma luta nem sempre fácil no Pantanal.

8. [...] nada segura NÓIS... se você vem com trator bem... se não vem... você vem a pé... ocê vem por dentro d'água... rasgando água pela cintura... espantando jacaré... sucuri... mas você vem emBORA... por quê? porque você é CRlado e nascido ALI... você não tem medo daquilo ali... né? você não tem medo...você tá vendo na sua frente três... quatro jacaré... você vai pra cima deles... eles que tem que saí de você né? então se você ficou nervoso... você vai larga o trator? você tem que tê muita paciência... tranqüilidade... pará pensa... cuma que eu tenho que fazê pra mim sai daí? (D1 - linhas 146 a 155)

9. [...] mas:... a gente tem que (caça jeito) pra fazer as coisa bem feito... pra você pode subi na vida... se você num fizé bem feito e com tranqüilidade... você num sobe nunca na vida... nunca... nunca... nunca...linhas 237 a 240.

10. [...] até você achá um meio de você tirá a condução que você atolou... pra pode vim embora... né? então... é onde você vai pegano média cos patrão... linhas 155 a 157.

11. [...] CAda vêis que você fazê você tem que fazer bem feito... bem FEITO... se você fizer bem feito... você vai te tudo... (...) éh:... que o patrão gosta... né? tudo que o patrão gosta... (D1 - linhas 215 a 218).

12. [...] a gente sente por eles também... a gente pretende cada vêis fazê o serviço mais melhor ainda que é pra agradá mais nosso patrão... (D4 - linhas 240 a 242).

Se nos exemplos anteriormente analisados, o sentido é de que aprender é sofrer, os exemplos de 08 a 12 possibilitam a construção de outros efeitos de sentido. Um dos sentidos é o de que com esforço você chega lá: [...] nada segura NÓIS... se você vem com trator bem... se não vem... você vem a pé... ocê vem por dentro d'água... rasgando água pela cintura... espantando jacaré... sucuri... mas você vem emBORA... (exemplo 8)/ [...] mas:... a gente tem que (caça jeito) pra fazer as coisa bem feito... pra você pode subi na vida... (exemplo 9)/[...] até você achá um meio de você tirá a condução que você atolou... pra pode vim embora... né? então... é onde você vai pegano média cos patrão... (exemplo 10). 
O outro possível sentido é o de que o esforço compensa: [...] se você fizer bem feito... você vai te tudo... (...) éh:... que o patrão gosta... né? tudo que o patrão gosta... (exemplo 11)/ [...] a gente pretende cada vêis fazê o serviço mais melhor ainda que é pra agradá mais nosso patrão... (exemplo 12). Nestes exemplos, se concretizam os efeitos de sentido que se constroem na relação de poder: tudo tem de ser bem feito para permanecer no trabalho, conservar uma boa imagem com o patrão e garantir boas referências para trabalhos futuros, em outras fazendas.

No caso do peão pantaneiro, é uma questão de sobrevivência que, como já referido, não tem sua própria casa. Sua imagem tem de ser preservada positivamente para garantir a sua provisão, a sua sobrevivência na região.

$\mathrm{Na}$ instauração dos efeitos de sentido da pedagogia pantaneira, a metáfora convencional VIVER É APRENDER se concretiza no exemplo abaixo. Neste trecho de sua história, o pantaneiro depois de colocar para a sua interlocutora todo o processo de aprendizado das atividades pantaneiras/atividades de trabalho no Pantanal, fecha o assunto com a expressão : [...] porque se você não aprende... você num VIVI... você não vive MESMO... (exemplo 13).

Segundo Silva (2003, p. 49), "a metáfora convencionalizada é a que os falantes são capazes de utilizar sem terem (ou sem precisarem ter) consciência da sua natureza metafórica". A metáfora VIVER É APRENDER é baseada na experiência e o pantaneiro, ao usar o recurso da repetição para intensificar/enfatizar que no Pantanal o aprendizado é fundamental, é uma questão de vida, não tem consciência da natureza metafórica de seu discurso, no exemplo a seguir, ele fala é da sua experiência de vida.

13. [...] éh um aprendiZADO... tudo que você aprende no Pantanal é um aprendizado... porque se você não aprende... você num VIVI... você não vive MESMO... (D1 - linhas 141 a 143).

Considerando que o sentido é determinado em um espaço de trocas no processo sócio-histórico em que os discursos são construídos, a metáfora é um movimento de sentido que produz efeitos (JOANILHO, 1996, p. 70), no discurso do pantaneiro a expressão [...] tudo que você aprende no Pantanal é um aprendizado... 
porque se você não aprende... você num VIVI... você não vive MESMO... traz um efeito metafórico que possibilita a construção de um efeito de sentido de que o trabalho faz parte da vida e, no caso do pantaneiro, é a própria vida, pois se ele aprende trabalhando, o VIVER É APRENDER. Se ele não aprende a desempenhar muito bem as suas funções, não consegue trabalhar e, conseqüentemente, não vive, como ele afirma no seu discurso.

Entendendo com Brandão (1994, p. 72) que o estudo da especificidade de um discurso se dá em relação com outros discursos, o autor da D1 constrói o seu discurso mostrando-nos a pedagogia do pantaneiro para viver e prover sua vida no Pantanal, a partir do discurso - que circula socialmente - do que seja o processo do aprendizado. Preti (1991, p. 62), ao tratar do discurso dos idosos, coloca que há nos idosos [...] um desejo de ensinar, de transmitir experiência às gerações mais jovens" o qual toma uma feição didática. O autor do D1 não é um idoso, mas apresenta essa "feição didática" que encontramos nas histórias dos outros três pantaneiros que pode ser entendida como um desejo de ensinar/explicar ao outro como é a vida de um pantaneiro.

Há nesse discurso uma boa vontade de ensinar, de transmitir experiências. O autor do D1 dá uma aula de vida no Pantanal, metodologicamente fundamentada. Não é possível esquecer, nessa leitura, que o outro dessa interação é alguém que, além de sua posição de leitora/pesquisadora, posiciona-se diante das histórias como quem trabalha com ensino e aprendizagem e esse aspecto, com certeza, implica em um posicionamento diverso do de um interlocutor que desempenhe outra atividade.

\subsection{Aprendendo a sobreviver}

A questão da sobrevivência permeia todo o discurso dos pantaneiros. O aprendizado dessa sobrevivência, do prover para a vida, pressupõe um enfrentamento diário às adversidades da natureza (reais), ao sobrenatural (o que está no imaginário), às relações com o patrão via capataz, à convivência com os vizinhos, à questão da saúde (o empecilho das longas distâncias e a cura pelas ervas). 
Entre as adversidades reais da natureza está a questão espaço/temporal: as longas distâncias que dificultam a locomoção, as características climáticas e de solo, como é possível evidenciar nos exemplos a seguir.

1. [...] então pra você locomove... as distâncias são muito grande... você teje de a pé... você teje de a cavalo... você teje em cima de um trator... tudo é longe... tudo é longe (disso aí (...) no Pantanal você anda o dia inteiro numa invernada e não chega no fim dela... são só fazenda grande... então as vêis você... dum retiro pro otro... você vai dum retiro... você sai da sede pra ir num retiro vinte quilômetro... né? se tá na seca você faz ele com duas hora... se tá na época das águas... você vai fazer aí... o dia inteiro e ás vêis não chega... você atola... você desatola... você atola e vai indo até você chegá no seu destino final... né? (D1 - linhas 27 a 39).

2. [...] as vêis a pessoa fica doente... não tem (otro)... não tem um trator... não tem nada pra levar ele... vai ter que sair uma pessoa de a cavalo... até chegar numa fazenda que tem um trator... pra podê avisá aquela pessoa... pra aquele trator í LÁ naquela fazenda... pra pegá a pessoa... pra trazer até onde tem um ponto de carro que pega a pessoa pra levá (pro hospital)...qué dizê que aí você já perdeu tempo... se é um causo de salva vida... você praticamente já tá... bem mal... né? (D1 - linhas 53 a 60).

3. [...] a gente morava du lado de lá do... do rio negro... então você pra vim na cidade... ou era avião... que era muito difícil naquela época... você num tinha contato... num tinha um telefone... num tinha um rádio... num tinha um nada... se você via um avião passa loNGE... você saia correndo... você precisando das coisas... você abanava com pano branco... né? pra vê se o avião enxergava... pra desce ali pra te dá um socorro... uma coisa... era muito difícil... e ... aí depois com tempo... a gente já conversô com os pilotos pra eles sempre dá uma... uma... passar (em frente) em cima... se a gente quisesse alguma coisa... fazia esse sinal que eu tô falando... com lenço branco... (pedia ajuda?)... exato... é porque era raro avião naquela época... (D2 - linhas 269 a 280).

É importante observar que esses aspectos se evidenciam nos depoimentos de D1 e D2 - pantaneiros que viveram no Pantanal em outros tempos. Os tempos das maiores dificuldades em que não existia a luz elétrica, o telefone e os meios de locomoção eram poucos e precários. Ao mesmo tempo em que relatam as 
dificuldades, eles se colocam como sujeitos capazes de encontrar os meios para enfrentá-las como mostra o exemplo 8 acima. Mostram-se destemidos diante das adversidades:

4. [...] nada segura NÓIS... se você vem com trator bem... se não vem... você vem a pé... ocê vem por dentro d'água... rasgando água pela cintura... espantando jacaré... sucuri... mas você vem emBORA... por quê? porque você é CRlado e nascido ALI... você não tem medo daquilo ali... né (D1 - linhas 146 a 150) .

5. [...] sempre era eu... eu era o mais velho dos irmão... né? eu vinha... eu ou o outro irmão ou um peão bom... fazia bota fora dele... atravessá aqueles curixo... aquelas vasantes... nadando... bola à pé e tal... atravessá o rio negro... a barra... largava ele aqui na Costa Rica... ele vinha pra Aquidauana... né? no caso de precisão... aí... ele largava o animal dele... em qualquer lugar do retirinho... -- por exemplo -- era um ponto de referência... aí... depois a gente pegava o animal... ou ele ia de condução ou chegava até Aquidauana de a cavalo... né? se ali já... aí nu retirinho sempre já tinha mais facilidade... ali já... a condução de vez enquando já vinha... (D2 - linhas 305 a 314).

No momento de encontrar saída, a identificação com o Pantanal se evidencia pela ênfase dada por meio da entonação e pelo dêitico ali: [...] você é CRlado e nascido ALI... .

Os autores do D3 e D4 viveram esses tempos, mas continuam trabalhando lá e em condições bem diferentes. Ainda que não pontuassem esses aspectos em suas histórias, mostraram o enfrentamento ao sobrenatural.

6. [...] aí eu ia indo na estrada e de longe eu vi... tava o luar claro... vi aquele tareco preto que vem vindo (eu falei "ih::: ai..ai..ai..") já pra tráis... já era uma metade grande pra mim vortá né? falei "pra mim vortá pra tráis num dá" lá vai eu pra frente... aí eu parei uma distância... parei fiquei meio de juelho... de olhá ele... vô vê que bicho que vem vindo aí... e ele veio vindo... mas ele é bem feio mesmo... aquele bicho tá loco... ele chegô uma dist/acho que ele nem me viu direito... porque eu tava/ele de certo vinha de cabeça baixa... sei lá eu... que vem... vem molengão... andando... tudo mole... mole... e eu falei... "daqui eu arranco... eu passo perto desse bicho e ele não vai vê que eu vô correndo daqui pra lá... né? ele vai pensá 
que/creio que passo perto dele" daqui eu arranquei meu Deus do céu... passei correndo muito duro perto desse bicho... e ele é um bichão curtão assim e alto assim... pel::: (pele) é um preto pel/ele é peludo... ele é um bicho preto... que a oreia dele... ele vai mexendo até... e a mão... e os cutuvelo dele que é... é um bicho feio demais... cheguei é muito assustado lá... lá na chácara... em casa... (D3 - linhas 163 a 179).

7. [...] sobre éh... assombração eu ouvi falá muito... já ouvi... muitas pessoa que correro de assombração... latão rolando atrás... couro fazeno baruio... fogo levantano... fogo... pé de arvre caino em outro lugar... só que eu nunca vi... nunca.. eu... andava à noite, viajano... até (pudia dizê) a gente fala que queria vê e era doido pra vê essas coisa... o fogo que levanta... mais nunca conseguia... num sei se é porque a gente é muito confiante a Deus... num sei... pode sê isso também... né? porque nada de... dessas coisa... aparece pra gente (D4 linhas 175 a 182).

Os exemplos apontam para a construção de sentidos diferentes em relação ao sobrenatural. O autor de D3, narra uma situação em que viu um lobisomem e dá detalhes de como fez para sobreviver à situação; nessa lembrança usa de hesitações ${ }^{113}$ ao rememorar o evento. Utiliza-se deste recurso em vários momentos do texto [...]... ele chegô uma dist/acho que ele nem me viu direito... porque eu tava/ele de certo vinha de cabeça baixa/ ele vai pensá que/creio que/ pel/ele é peludo, possibilitando algumas construções de sentido. Estava nervoso só de relembrar o medo que havia passado ou, considerando que o texto oral se constrói no momento da interação, o pantaneiro procurava as palavras para dar maior veracidade ao fato. Pode ser também que estivesse procurando as palavras para convencer a interlocutora e se convencer de que o fato realmente aconteceu, já que ele se coloca como testemunha dele.

O autor do D4 se apresenta como aquele que não testemunhou nenhum fenômeno sobrenatural, até hoje. Conhece histórias de outros que viram [..] eu ouvi falá muito... já ouvi... muitas pessoa que correro de assombração... latão rolando atrás... couro fazeno baruio... fogo levantano... fogo... pé de arvre caino em outro

113 Marcuschi (1999, p.164) ao tratar das características da hesitação, mais especificamente das pausas, afirma que "a posição da pausa é relevante para determinar se sua ocorrência deve-se a uma atividade de planejamento sintático ou de busca de um item lexical". Os falsos inícios estão dentro da classificação das pausas e são definidos pelo autor como "todos os inícios de unidades sintáticas oracionais, que são iniciados com algum problema e refeitos ou retomados".Ex.: dep/antes de Hair eu assisti um outro uma outra peça. 
lugar... só que eu nunca vi... e justifica o fato e/ou a sua frustração, colocando-se com um sujeito de fé [...] num sei se é porque a gente é muito confiante a Deus... num sei... pode sê isso também... né?.

Outro aspecto fundamental em relação à sobrevivência já pontuado, de maneira breve, nesta análise é o que trata das relações patrão/peão. A interlocução é intermediada pelo capataz ou gerente que é a autoridade imediata a quem o peão presta conta de suas atividades. A relação do patrão com o peão depende da relação do peão com o capataz e esta é a que define a permanência do peão, naquela fazenda ou não. O discurso de S.N.C. evidencia essas relações de trabalho e poder.

8. [...] tudo você vai aprendeno conforme os... os líder da cabeça... que é o capataz... se não tem o gerente é o capataz... se tem o gerente... primeiro é o gerente... você vai lá... você vai degavar... você pode chegá lá à tarde... já tem outros que fala.... "não... eu quero que você chega aqui meio dia" você tá lá... aí você tem que:.. apertá... então é muito difícil... se você vai sai duma fazenda pra otra pra/pra trabaia... eles vai pedi informação por que que você saiu de lá? o quê que você fez lá? né? "mas por que que ele saiu daí?" "ah... ele saiu daqui porque brigou com capataz" "mas por que que ele brigou com capataz? o que que o capataz fez com ele?"... né? "ah... 0 capataz xingou ele" "ah... então ele não trabaia aQUI"... (D1 linhas 181 a 192).

Além das expressões lingüísticas já tratadas nesta análise, o uso que o autor do D1 faz do discurso direto se constitui de uma heterogeneidade mostrada e marcada em que, em sua relação com o outro, com o seu exterior, procura reforçar à sua interlocutora como ocorre essa troca de informações sobre o motivo da saída de peões das fazendas. O texto mostra a importância da função de capataz/gerente, tendo em vista que são eles que dirigem a maioria das fazendas. A compreensão que se evidencia no discurso do autor do D1 é, como já referido, a relação de poder que se presentifica nas relações de trabalho no Pantanal.

9. [...] num respondo pra eles... cum/num faço isso... então o que eles falá pra mim... pra mim tá tudo bem... éh:.: éh::.: isso aí que to/porque... se eu sô um ruim... um cara... um funcionário ruim... então eu se eu i pra quela outra fazenda ali... eles vão 
ligá pra cá... tirá a saber o quê... o quê que eu era... o quê que eu sô... se eu sô um peão bom... se eu sô um peão ruim... as veiz o peão é bom... mas... ele é... ele é ruim né? ( D4 - linhas 192 a 198).

Essas relações de trabalho se constituem em relação de dominação que vai permear a condição de sobrevivência do pantaneiro, na região. Entretanto, essa prática não se dá em todas as fazendas, nem foi sempre dessa maneira. Existem fazendas em que as relações são de confiança e respeito.

O relacionamento com os vizinhos é outro ponto importante na questão da sobrevivência. Normalmente essa relação é de solidariedade, hospitalidade e ajuda mútua, com podemos observar nos exemplos a seguir.

10. [...] se você chegá numa casa dum pantaneiro... a primeira coisa que ele pergunta pra você — você já comeu? você já armoçou? você quer tomar um tereré? ele qué sê/ele qué fazê você feLIZ... aquilo ali pra ele éh um prazer... né? (D1 - linhas 307 a 311).

11. [...] se você quebrá um carro aí ó... e pedi pra uma fazenda í puxá pra você e levá até num recurso... ninguém LEva... e no pantanal... as vêis... se uma pessoa anda aí... levando um trator que quebrou aí... as vêis... trinta... quarenta quilômetro... quanto custa isso? num custa nada... por quê? porque ele faz pra você hoje... amanhã você faz pra ele... então... são trocado... isso é trocado... né? ninguém cobra nada de ninguém... (D1 - linhas 327 a 329).

12. [...] aí... a gente foi morá com a vó... minha vó era uma gaúcha MUlto trabalhadeira... MUlto dinâmica...juntô todo mundo num lugar só... aprendemos muita coisa com ela... ajudávamos ela fazer flores (sabe?)... pra podê ganhá o pão... (e) teve muito ajutório... do Cel. Z. (esse povo antigo aqui) ajudou muito ela porque eles eram do Rio Grande... né?... então:... eles ajudaram muito a gente... aí... (D2 - linhas 06 a 12).

O sentido que se constrói é o de que as longas distâncias, o isolamento em relação às cidades e a característica de solo da região aproximam as pessoas. E a tendência é manter-se em razão do ecoturismo que promove atividades integradas de várias pousadas e fazendas. Há também o fato de que se o fazendeiro ou um de 
seus empregados desrespeitarem regras como, ao passar, deixar as porteiras sempre fechadas, ele pode ficar sem condições de sair ou entrar em sua fazenda.

O pantaneiro encontra na natureza a solução para a questão da saúde, com podemos observar no discurso do autor de $D 4$ :

13. [...] os remédio no Pantanal sempre é raízes... né? tem a vassorinha... a vassorinha é boa pra:.: machucadura... u::: (gervão) também... é uma pranta também medicinal também...é boa também pra:: pra ( ) machucadura também... ou aquele capim amargoso também... u::.: queima ele e tira aquela cinza dele... se cortô o pé... na perna... põe aquela cinza em cima... amarra... ele é também contra... pra ficá sangrano... é também ele estanca sangue e tem...certo tipo... também pra tosse... né? pra tosse... forte mesmo... é a raiz de:.. ( ) com:.: caraguatá... que é a raiz do jatobá... então é bom até pra:... pra (pontada) pneumonia também... e a pena de angola também que é propriado pra (pontada) pneumonia também... então... remédio daqui do::: do... do Pantanal mesmo tem VÁrios tipo de remédio... tem remédio depurativo pru sangue também que é (cancorosa)... né? tem vários tipo de remédio aqui no Pantanal nosso... que:.. assim... as vêis no momento... a gente esquece os nome dele... né? (...) toda vida... sempre... porque no Pantanal era difícil... né? então as vêis falava "ah! tem o fulano lá... que ele sabe que... que raiz que é bom”.. então a gente ia lá... atrás do:: daquele cidadão que já é mais antigo né? ia lá ele arrumava aquela... aquela garrafada de raiz e entregava... falava "daqui uma semana você pode vir aqui... que você tá são" eh era... certinho... (D4 - linhas 148 a 168).

14. [...] num existia vacina aqui antigamente... num existia isso... era só remédio de mato mesmo... dor de cabeça... essas coisa... num tinha negócio de:.: pastilhinha pra tomá... porque tô com dor de cabeça vô tomá um remédio.... não... não existia... era o remédio do mato mesmo... queu pra dor de cabeça - - por exemplo - - tá forte... faz um chá daquela... de:.. fedegoso... fedegoso.... bateu aquilo já... já beleza... (D4 linhas 169 a 174).

Sofrendo as dificuldades do enfrentamento das longas distâncias, da locomoção para trazer o doente às cidades mais próximas, o pantaneiro [...] perscrutador da flora e fauna para descobrir-Ihes as mudanças de comportamento" (NOGUEIRA, 1990, p. 65) encontra nas ervas medicinais a possibilidade de cura para as doenças. 
As expressões [...] era só remédio de mato mesmo/ num tinha negócio de:.:. pastilhinha pra tomá... mostram a importância dos elementos naturais na medicina doméstica do pantaneiro. São expressões presentes no senso comum que compreendem o que Bakhtin (1986, p. 118-119) chama de ideologia do cotidiano. $O$ autor conceitua a ideologia do cotidiano como [...] a totalidade da atividade mental centrada sobre a vida cotidiana, assim como a expressão que a ela se liga". É aí que se dá o surgimento ainda primário da ideologia e onde a mudança ocorre de forma lenta, tendo em vista que os signos estão diretamente em contato com os acontecimentos socioeconômicos (MIOTELLO, 2005, p. 173-174).

\subsection{Em contraponto}

Os pantaneiros, em de seus depoimentos, apresentam o Pantanal e a si mesmos, por meio de relações opositivas. Usando a repetição/reiteração (62 ocorrências): 38 no D1, 15 no D2 e 09 em D4) das expressões é difícil... / é muito difícil.../não temos nada fácil.../é sacrificoso..., em oposição às expressões é bom.../ é gostoso.../a vivência é boa.../ muito boa.../ a vida é tranqüila.../ é divertido (29 ocorrências; 14 no D1, 08 no D2, 02 em D3 e 05 em D4) mostram o Pantanal pela oposição: é difícil mas é bom.

Koch (1987, p. 104-108), fundamentada na tese defendida por Ducrot, Anscombre e Vogt, afirma que a argumentatividade está inscrita na própria língua e considera que é constitutivo de cada enunciado o fato de orientar a seqüência do discurso, determinando os encadeamentos possíveis com outros enunciados que possam dar-Ihe continuidade. Dentre esses enunciados, há aqueles que são usados com a pretensão de orientar o interlocutor para certos tipos de conclusão. Dentre eles, estão os operadores argumentativos ou discursivos que são responsáveis por esse tipo de relação.

Os operadores argumentativos ganham essa função dentro da semântica argumentativa que defende serem eles que determinam o valor argumentativo dos enunciados com marcas lingüísticas importantes da enunciação. Para a gramática 
normativa são elementos meramente relacionais: os conectivos e os vocábulos que segundo a N.G.B ${ }^{114}$., não pertencem a nenhuma das dez classes gramaticais.

O morfema mas funciona como operador argumentativo, sendo considerado por Ducrot com o operador argumentativo por excelência. As expressões coordenadas por mas apresentam orientações argumentativas opostas em que a força maior está centrada na expressão que vem depois de mas. No caso da relação que se inscreve nos textos dos pantaneiros, a força maior está na expressão é bom a qual possibilita a construção de sentido de que, no Pantanal, a vida pode ser difícil mas é boa, como podemos ver nos exemplos a seguir.

1. por isso que eu falo "o Pantanal éh bom... éh bom... mas a dificuldade lá não é fácil... não é fácil mesmo”... ( D1 - linhas 63 a 65).

2. éh... éh era dificultoso... não era fácil não... (e era bom?) mas ah... num tem dúvida... aquilo pra nóis era uma farra... era um negócio gostoso... você fazia aquilo com prazer... né? com prazer... ( D2 - linhas 327 a 330 ).

Temos, nesse caso, um aspecto persuasivo marcado pelo operador argumentativo mas, que o pantaneiro usa no seu discurso em duas direções: em relação à interlocutora e em relação a ele mesmo - pela memória, ele reconstrói o passado e faz um balanço em que busca persuadir-se com as seguintes afirmações: é difícil... é muito difícil ....não temos náda fácil, mas é bom, é prazeroso, é gostoso. Procura convencer-se de que o esforço compensa.

Outra oposição que emerge dos discursos é a do antigamente $X$ hoje, em um sentido avaliativo. A situação hoje é melhor em termos de infra-estrutura (D1linhas 72 a 73), relações de trabalho (D1- linhas 354 a 356), facilidade de acesso às cidades e às fazendas (D2 - linha 208), educação dos filhos (linhas 348 a 360), mas piorou em termos de adaptação dos mais jovens ao trabalho no Pantanal (D2 linhas 353 a 356), solidariedade, hospitalidade (D2 - linhas 190 a 195), tratamento da saúde (D4 - 180 a 183) e relação com o dono da fazenda (D1 - linhas 181 a 183).

\footnotetext{
${ }^{114}$ Nomenclatura Gramatical Brasileira.
} 
Antigamente a situação era melhor em relação à solidariedade (D2 - linhas 177 a 179), jovens bem adaptados ao Pantanal (D2 - linhas 350 a 353), tratamento da saúde (D4 - 174 a 179), relação com o dono da fazenda (D4 - 304 a 308), mas era pior em relação à infra-estrutura (D1 - linhas 73 a 75), relações de trabalho (D1 linhas 355 a 356), ao acesso às cidades e às fazendas (D2 - linha 208 a 209), educação dos filhos (linhas 16 a 19).

Essa oposição, presente nos discursos, evidencia que melhorou e o que piorou com as mudanças de infra-estrutura que vêm ocorrendo no Pantanal, do ponto de vista desses pantaneiros.

Nos discursos analisados e de acordo com a abordagem colocada pelos autores da obra Metáforas da Vida Cotidiana e outros estudiosos da metáfora do cotidiano, destacamos as metáforas convencionais TRABALHO É RECURSO, TRABALHO É SOFRIMENTO, TRABALHO É PRAZER, VIVER É APRENDER, VIVER É LUTAR, FELICIDADE É VIVER BEM, FAMÍLIA É UNIÃO e a metáfora orientacional BOM É PARA CIMA, procurando pensá-las nos textos dentro de um processo de produção de sentidos que se dá na interação.

Para tanto, elencamos nos depoimentos, expressões lingüísticas que concorrem para a construção do conceito metafórico:

A) TRABALHO É RECURSO:

1) [...] ajudávamos ela fazer flores (sabe?)...pra podê ganhá o pão. - (D2 -linha 9)

2) [...] fazia de tudo (na vida) ...fomos casqueiro, naquela época tirava muita casca...de madeira, de angico... pra vende:.:: fazia contrato com a Noroeste do Brasil... (D2-linhas 10 e 11)

3) [...] a gente domava naquele tempo diz que prá ganhá mais dinheiro... (D2-linha 19).

4) [...] ele me deu uma égua velha e um burro aporriado e dez égua pra mim domá se eu quisesse andá a cavalo... (D2-linhas 37 e 38$)$. 
5) [...] aí o E. me levou...pro Pequi... aí eu já fui ser capataz mais evoluído, né! Mais ...melhorado. Aí passei a gerente... (D2-linhas 42 e 43).

6) [...] o melhor emprego é de fazenda...o cara..que se ...se ele soube se tive ambição de ter alguma coisa, ele tem... porque é só ele economizá... ganhá ele ganha bem...coMlda ele tem todo mês o patrão leva... carne ele tem na fazenda, ele não vai prá frente porque ele não quer... moradia, água, luz...não paga nada... [D2-linhas 47 a 50]

\section{B) TRABALHO E SOFRIMENTO;}

1) e daí que a gente começava a sofrer MAIS que a vida de campero... (D1 - linhas 12-3)

2) ele vai deixá você sofre um pouco... que é pra você aprende... pra vê se você tem paciência... (D1 -linhas 133-4)

3) trabalhando nu campo... um touro trompo na perna dele.... e quebrô... (D3-linhas 11-2)

4) pra onde eu cheguei hoje... eu passei por muita dificuldade dentro do Pantanal... que antigamente era muito difícil... (D4linhas 81-2)

\section{C) TRABALHO É PRAZER}

1) aqui é tudo muito bom... bom... tudo mundo trata um cum o outro brincando... num... num... manhece ninguém brabo com ninguém.... desde a hora que a gente se levanta cedo aqui um brincando com o outro... tirando sarro e vai indo... é até de noite... eles vão fazê o serviço deles ali... eu pego vô fazê o meu... (D3-linhas 126-9)

2) porque... que eu fico mexendo cum eles e eu quero que a pessoa então... ele sai... ele sai daqui contente... sai sastisfeito... né? nóis trata bem eles... (D3-linhas 202-3)

3) [...] Trabalho... o que eu posso fazê, até fico inquieto, quando eu tenho que, eu tô à toa, não sei fica à toa, é eu quero, quero agir, quero... quero saí, enfim,(D2-linhas 219-21) 
4) é mexe o doce né? Como falam. Tem que mexe o doce senão não vai. (D2-linhas 137 a 139).

5) [...] você fazia aquilo com prazer...né?! Com prazer, e... ganhava 5.000 mil réis por mês (risos) é, era mil réis... (D2linhas 204 e 205).

6) as responsabilidade que eu tenho... que eu uso aqui dentro da empresa e com grande carinho... (D4-linhas 123-4)

7) trabalho aqui tudo trabalho que eu faço aqui... eu faço cum carinho... in:.. através dos carinho... (D4-linhas 238-9)

8) felicidade pra mim... éh:: quando eu tô atendeno um grupo bão... um grupo especial... (D4-linhas 248-9)

Em relação à natureza metafórica do trabalho, o discurso do pantaneiro aponta para construção de três efeitos de sentido sobre essa experiência: o trabalho como um recurso para prover e sobreviver; o trabalho sacrificado, difícil que está do lado do é difícil na relação opositiva; e o trabalho como prazer, integrando o lado do é bom da relação opositiva no Pantanal tudo é difícil, mas é bom.

\section{D) VIVER É APRENDER:}

1) ... éh um aprendiZADO... tudo que você aprende no Pantanal é um aprendizado... porque se você não aprende... você num VIVI... você não vive MESMO... (D1linhas 141-3)

2) [...] aprendemos muita coisa com ela... ajudávamos ela fazer flores (sabe?)...pra podê ganhá o pão. (D2-linhas 5 e 6)

3) [...] lá a gente aprendeu de tudo... estudamo um pouco ...eh.:.: trabalhava (...) era campeiro também... (D2-linhas 14 a 16). 
4) [...] aí eu fui ser capataz mais evoluído né? (D2-linha 42).

5) [...] Ele me orientou...e que me ensinou também muitas coisas, formação de PASTO... foi MEU professor... (D2-

E) VIVER É LUTAR: linhas 57 e 58).

1) mas a vida deles são muito difícil... não é fácil não... a vida deles... (D1-linhas 42-3)

2) nada segura NÓIS... se você vem com trator bem... se não vem... você vem a pé... ocê vem por dentro d'água... rasgando água pela cintura... espantando jacaré... sucuri... mas você vem emBORA... (D1-linhas 146-9).

Os conceitos metafóricos que se depreende das metáforas acima estão relacionados com a vida do pantaneiro que é o trabalho e se esse trabalho é difícil e é um aprendizado, sua vida é uma vida de luta e de aprendizado.

\section{F) FELICIDADE É VIVER BEM}

1) aqui a vida é mais tranqüila... dorme tranqüilo... (D3 linhas 100-1).

2) então... é minha felicidade é eu tê saúde e boas amizades... né? como... como eu... eu me sinto bem aqui porque desde que eu cheguei aqui acho que todo mundo gostou de mim... (D3-linhas 188-90).

3) éh:: o que eu sinto do... daqui do Pantanal nosso... queu... queu gosto muito de convivê no dia-a-dia aqui dentro do Pantanal... porque é um lugar gostoso... é um ar puro que a gente respira todos os dias... (D4-linhas 124-7).

4) eu acho que a felicidade da gente... é vive bem... né? (D2-linha 240)

G) FAMÍLIA É UNIÃO 
1) ser amparado pelo menos tê uma casa... tê a família junto... num é? éh... o quê eu sempre falo pros meus filhos... (D2-linha 241 -3)

2) assim numa fazenda que tivesse condições de nóis morá junto... com a faMília estudano... tudo junto... aí... então... mais num é fácil... mas graças a Deus consegui a fazenda... que foi aí... pertinho de:.. de Campo Grande... então tinha condução que levava até Campo Grande e trazia até a fazenda... aí nóis mudemo tudo junto... aí você fica em:.. harmonia com a família... (D1- linhas 4637)

3) aí eu fui caçando um jeito de trabaia só onde tem escola... então... onde tivé escola... que cabe eu com a minha família... eu vo trabaia lá... (D1-linhas 482-4)

4) profissão de campero... aí... foi quando eu conheci essa minha esposa... que eu vô fazê trinta ano de casado né? (D4-linhas 47-8)

5) de jeito nenhum... porque aqui eu moro... convivo com a minha esposa... tenho uma convivência boa... nunca briguei com a minha esposa... nunca tivemo discussão... tenho cinco filhos... (D4-linhas 68-71)

As metáforas FELICIDADE É VIVER BEM e FAMÍLIA É UNIÃO compreendem a visão de mundo dos pantaneiros em relação à instituição família e à felicidade.

H) BOM É PARA CIMA

1) por isso que eu falo "o Pantanal éh bom... éh bom... (D1linhas 63-4)

2) então é por isso que as vêis a gente fala que o Pantanal éh bom... (D1 - linhas 93-4)

3) a vivência é muito BOA... muito BOA... acho que o Pantanal... éh uma área do Pantantal que éh... vamos supô assim... ingnorância existe em qualquer lugar do Brasil... mas o pantanero... você pode andá dentro do Pantanal... não existe ingnorância... não existe 
ingnorância... são as pessoas... tudo quanto éh lugar que você chegá... você é bem tratado... (D1 -linhas 300-6)

4) que eu sô... se eu sô um peão bom... (D3 -linhas 196-7)

5) ele era um senhor de Lavínia e tinha fazenda em Dourados... homem bom... caboclo... caboclo bom... ele (D2 -linhas 87-8)

A metáfora orientacional BOM É PARA CIMA, possibilita a compreensão da imagem que o pantaneiro tem do Pantanal. Esse sentido está integrado ao contexto da relação opositiva no Pantanal tudo é difícil, mas é bom. Considerando os modos de enunciação, todas essas metáforas são modos de dizer do pantaneiro, para referir-se ao Pantanal, aos companheiros e a si próprio.

Ao finalizar a análise, procuramos ressaltar algumas considerações sobre 0 gênero do discurso depoimento oral e sua construção, a partir das características que the são próprias. Considerando o estilo desses depoimentos, vamos observar a evidência de um diálogo cristalizado pela presença de pré-construídos - como: mingúem é perfeito; a ignorância existe em qualquer parte do Brasil; com esforço se chega lá; briga não dá camisa pra ninguém; e ele (filho) não pede para nascer - e que marcam a interdiscursividade do texto.

As marcas da oralidade, com destaque para a repetição, que permeou marcadamente o Depoimento 1- (D1) e os outros em menor proporção, ocorreram de três formas. Em primeiro lugar, pela intensificação que ocorreu com a maioria das ocorrências analisadas Em segundo lugar pela mimetização da ação: [...] você atola... você desatola...você atola e vai indo... e, em terceiro lugar, pela função de reconstrução da memória.

As relações de oposição analisadas, as metáforas do cotidiano e os efeitos de sentido que se concretizaram nas expressões: aprender é um processo gradativo; se aprende a fazer fazendo, estruturam- se no interior de uma ideologia do cotidiano que mostra o que afirma Miotello (2005, p. 175)

"O meio social envolve, então, por completo o indivíduo. O sujeito é uma função das forças sociais. O eu individualizado e biográfico é quebrado pela função do outro social. Os índices de valor, adequados a cada nova situação social, negociados nas relações interpessoais, preenchem por completo as relações Homem $\mathrm{x}$ Mundo e as relações Eu x Outro". 
Despalavra

Hoje eu atingi o reino das imagens, o reino da despalavra. Daqui vem que todas as coisas podem ter qualidades humanas. Daqui vem que todas as coisas pode ter qualidades de pássaros. Daqui vem que todas as pedras podem ter qualidades de sapo. Daqui vem que todos os poetas podem ter qualidades de árvore.

Daqui vem que os poetas podem arborizar os pássaros. Daqui vem que que todos os poetas podem humanizar as águas. Daqui vem que os poetas devem aumentar o mundo com as suas metáforas.

Que os poetas podem ser pré-coisas, pré-vermes, Podem ser pré-musgos.

Daqui vem que os poetas podem compreender o mundo sem conceitos.

Que os poetas podem refazer o mundo por imagens, por eflúvios, por afeto.

(Manoel de Barros, Ensaios Fotográficos, 2000, p. 23) 


\section{CONCLUSÃO}

O ponto de partida desta pesquisa tem seu fundamento nas seguintes indagações: em que medida se constrói a imagem do pantaneiro através de seu próprio discurso? Ou, mais especificamente, em que medida é possível evidenciar as imagens do pantaneiro construídas pelo discurso oral do próprio pantaneiro? $\mathrm{Na}$ busca das respostas a essas indagações estabelecemos os seguintes objetivos: conhecer a construção das representações instituídas como sendo a imagem do pantaneiro nas histórias de vida do próprio pantaneiro e buscar nas histórias de vida desses pantaneiros a imagem discursivamente construída do homem pantaneiro.

No encaminhamento ao alcance dos objetivos, buscamos na Análise do Discurso $(A D)$ os fundamentos teóricos para a análise dos quatro depoimentos dos pantaneiro selecionados. Por meio dos mecanismos interdiscursivos, que remetem à relação texto-contexto, examinamos esses discursos, levando em conta a interdiscursividade que remete a noções como heterogeneidade discursiva, sujeito, condições de produção entre outros que se inserem no quadro da $A D$ e que fazem parte do processo interlocutivo.

Tendo em vista que estávamos trabalhando com gêneros do discurso da modalidade oral, sentimos a necessidade de buscar, nos estudos da gramática do português falado e na análise da conversação, os fundamentos que explicam as especificidades desse gênero discursivo. Isso foi feito dentro das necessidades de explicitação desses aspectos teóricos no interior da própria análise.

Esses aspectos teóricos foram analisados a partir de três eixos pensados por Geraldi no que diz respeito ao sujeito e suas ações: as ações que se realizam com a linguagem, as ações que se realizam sobre a linguagem e as ações da linguagem. Considerando que esses aspectos teóricos se entrecruzam e compreendem um todo no processo discursivo - no momento da análise optamos por não tratá-los separadamente, mas no contexto.

Consideradas as perspectivas teóricas escolhidas, procedemos à análise dos depoimentos que nos possibilitou algumas conclusões. A primeira delas considera que do lugar que ocupam, ao enunciar o seu discurso, os pantaneiros se 
colocam como trabalhadores do pantanal, evidenciando as diversas funções que desempenham. Todos os pantaneiros, ao narrarem suas vidas, remetem ao trabalho, tanto às atividades que exerceram, como às que realizam atualmente. Assim, o que temos é um pantaneiro que, ao narrar a sua vida sempre se refere ao trabalho representado pelas diversas atividades que desempenha, como podemos constatar pela análise dos depoimentos.

Esse trabalho é caracterizado por meio das dificuldades, ou seja, é bom viver no Pantanal, mas não é fácil. O trabalho é difícil e essa dificuldade decorre de alguns aspectos evidenciados no discurso como, por exemplo, o tipo de atividade, as possibilidades de locomoção, as distâncias e os fenômenos da natureza. É um sujeito que se caracteriza também pela mobilidade. Mobilidade essa que, principalmente hoje, é muito forte em razão das condições de trabalho. Na esperança de encontrar um trabalho que Ihes ofereça melhores condições de vida, vai mudando e, dessa maneira, torna-se itinerantes, não se enraíza em lugar algum.

É um trabalhador que muitas vezes não tem o seu próprio espaço para morar, não tem muitas possibilidades e opções de lazer; que trabalha duro e gosta do Pantanal. É um trabalhador que, na maioria das vezes, não conhece o patrão, que lá aparece de vez em quando e trata diretamente com o capataz e/ou gerente, o qual, por sua vez, repassa as orientações e/ou ordens aos peões. No espaço de trocas - que constituem a interdiscursividade - e que se dá entre o discurso de autoridade do patrão e a prática do peão pantaneiro, está o capataz e/ou gerente que pode construir o seu próprio discurso de autoridade em relação a esses peões e suas práticas, que não será aquele do patrão, mas um outro resultante das relações amistosas ou não com esses peões. Marca-se então como a figura de dominação nas relações de trabalho desse contexto.

Concluímos que esses pantaneiros apresentam-nos o Pantanal e a si mesmos por meio de relações opositivas. Em relação ao Pantanal, a imagem que fazem é de um lugar que é difícil mas é bom. Outra oposição que emerge dos discursos é a do antigamente $X$ hoje, em um um sentido avaliativo das condições de vida e trabalho na região.

O pantaneiro fala sobre o Pantanal como alguém conhece a região. Utilizase de recursos lingüísticos da oralidade (repetição, dêixis, analogias, metáforas do cotidiano) para agir sobre o interlocutor e construir sua imagem perante esse 
interlocutor. Uma imagem de morador dessa região que não é o dono. As operações que faz com a língua é o meio de se construir pela linguagem.

A predicação que faz do Pantanal se dá por essa estrutura opositiva que evidencia a contradição na qual ele mesmo vive: o Pantanal é difícil, mas é bom; "eu vivo aqui, mas não quero isto para os meus filhos".

Dessa maneira, a imagem desse pantaneiro que se dá pelo discurso da oralidade, mostra a prática da vida, o ensinamento prático que se presentifica em uma ideologia do cotidiano. É a imagem da repetição na linguagem que mostra que o trabalho dele é assim, o ritmo no espaço pantaneiro é assim.

No conduzir de um gado, que é tarefa monótona, de horas inteiras, às vezes de dias inteiros, - é no uso de cantos e recontos que o pantaneiro encontra o seu ser. (BARROS, Manoel - O Livro de Précoisas, 1985, p. 35 ) 


\section{REFERÊNCIAS}

ARAÚJO, Carla B. Zandavalli M.; DEL MORO, Ederly Loureiro; FIGUEIRA, Kátia Cristina N. Trabalhos Monográficos: Normas Técnicas e Padrões. Campo Grande: Editora da UNIDERP, 2002.

ASSOCIAÇÃO BRASILEIRA DE NORMAS TÉCNICAS. NBR 10520: Apresentação de citações em documentos. Rio de Janeiro, 2001.

Elaboração. Rio de Janeiro, 2000.

NBR 6023: Informação e documentação. Referências.

BAKHTIN, M. Marxismo e filosofia da linguagem. 3ae ed.São Paulo: Hucitec, 1986.

BENVENISTE, Émile. Problemas de lingüística geral I. Tradução: Maria da Glória Novak e Maria Luiza Néri. Revisão: Isaac Nicolau Salum. 3. ed. Campinas: Pontes, 1991. Coleção Linguagem Crítica.

Guimarães (et al). Campinas: Pontes, 1989. Coleção Linguagem Crítica.

Problemas de lingüística geral II. Tradução: Eduardo BRAIT, Beth (Org.). Bakhtin: outros conceitos-chave. São Paulo: Contexto, 2006.

BRANDÃO, Helena Hatsue Nagamine. Gêneros do Discurso e Tipos Textuais. In: SECRETARIA DE ESTADO DE EDUCAÇÃO DE SÃO PAULO - PEC: Programa de Educação Continuada - CENP/SEE-São Paulo, 2002

UNICAMP, 1994. Série Pesquisas.

. Introdução à Análise do Discurso. 3. ed. Campinas: Editora da

Subjetividade, Argumentação, Polifonia. A propaganda da

Petrobrás. São Paulo: Fundação Editora da UNESP: Imprensa Oficial do Estado, 1998.

$\overline{\text { 2002, p.4 (mimeo). }}$

A articulação: gêneros do discurso e ensino. São Paulo:

CABRAL, P. E. Educação Escolar Indígena em Mato Grosso do Sul: algumas reflexões. Secretaria de Estado de Educação de Mato Grosso do Sul - Campo Grande, 2002.

CARDOSO, Sílvia Helena Barbi. Discurso e Ensino. 2. ed. Belo Horizonte: Autêntica, 2003.

CHARAUDEAU, Patrick. Dicionário de Análise do Discurso. Tradução: Fabiana Komesu. São Paulo: Contexto, 2004.

CLARK, Katerina; HOLQUIST, Michael. Mikhail Bakhtin. Tradução: J. Guinsburg. São Paulo: Perspectiva, 1998, Coleção Perspectiva. 
COSTA, Maria de Fátima. História de um País Inexistente: Pantanal entre os séculos XVI e XVIII. São Paulo: Estação Liberdade - Kosmos, 1999.

COURTINE, J.J.. "La notion de "condition de Production du Discours". IN: Analyse du discours politique (le discours communiste adress aux chrétiens). Langages 62, juin, 1981, Paris, Larousse, p. 19-32.

DE BARROS, Manoel. Livro de pré-coisas: roteiro para uma excursão no Pantanal. Rio de Janeiro, Philobiblion, 1985.

DE BARROS, Manoel. O Livro das Ignorãças. 10. ed. Rio de Janeiro: Record, 2001.

DE BEAUGRANDE, R. A análise do discurso no Brasil do 'mercado livre’. .Site: 'http://beaugrande.bizland.com/discurso/no/brasil/mercadolivrè/, Acessado em $30 / 08 / 2005$.

FIORIN, J. L. Interdiscursividade e intertextualidade. In: BRAIT, B. (org.) Bakhtin: outros conceitos-chave. São Paulo-SP: Contexto, 2006, p. 161-193.

GADET, Françoise; HAK, Tony (Orgs.). Por uma Análise Automática do Discurso: uma introdução à obra de Michel Pêcheux. Tradução: Bethânia S. Mariani (et al). 3. ed. Campinas: Editora da UNICAMP, 1997.

GALEANO, Eduardo. As veias abertas da américa latina. Tradução: Galeano de Freitas. 32. ed. Rio de Janeiro: Paz e Terra, 1991. Estudos latino-americanos, v. 12.

GERALDI, J. Wanderley. Linguagem e Ensino: exercícios de militância e divulgação. Campinas: Mercado de Letras, 1996.

Portos de Passagem. São Paulo: Martins Fontes, 1991.

GREGOLIN, Maria do Rosário. Foucault e Pêcheux na construção da análise do discurso: diálogos e duelos. São Carlos: Claraluz, 2004.

HARRIS, Z.S. Discourse Analysis. Language, volume 28, pp.1-30, 1952. Tradução francesa em Langages no 13, mars 1969, Didier/Larousse, Paris.

INDURSKY, Freda; FERREIRA, Maria Cristina Leandro (Orgs.). Michel Pêcheux e a análise do discurso: uma relação de nunca acabar. São Carlos: Claraluz, 2005.

JANUÁRIO, Elias Renato da Silva. et al. Fronteira: memória e linguagem. Campinas: Pontes, 2001.

JOSÉ DA SILVA, G. A construção física, social e simbólica da Reserva Indígena Kadiwéu (1899-1984): memória, identidade e história. Dourados-MS: UFMS, 2004, 144p., (Dissertação de Mestrado).

JOSÉ DA SILVA, G. \& SOUZA, J.L. O despertar da fênix: a educação escolar como espaço de afirmação da identidade étnica Kinikinau em Mato Grosso do Sul. SOCIEDADE E CULTURA, V. 6, N. 2, JUL./DEZ. 2003, P. 199-208. 
$\mathrm{KOCH}$, Ingedore G. Villaça (Org.). Gramática do Português Falado. 2. ed. rev. Campinas: Editora da UNICAMP, 2002, V. 6, Desenvolvimentos.

A inter-ação pela linguagem. 2. ed. São Paulo: Contexto, 1995. Coleção Repensando a língua portuguesa.

Argumentação e Linguagem. 2. ed. São Paulo: Cortez, 1987.

LAKOFF, George; JOHNSON, Mark. Metáforas da Vida Cotidianan. Tradução: Mara Sophia Zanotto (Coord.). Campinas: Mercado das Letras, 2002. Coleção As Faces da Lingüística Aplicada.

MAINGUENEAU, D. Novas tendências em Análise do Discurso. Trad.Freda Indursky. Campinas-SP: Pontes: Edit. Da Universidade Estadual de Campinas, 3a edição, 1997.

Criar Edições, 2005.

Gênese dos Discursos. Tradução: Sírio Possenti. Curitiba:

MALDIDIER, D. Elementos para uma história da Análise do Discurso na França. IN: ORLANDI, Eni P. (Org.) Gestos de leitura - da história no discurso. $2^{a}$ ed., Campinas-SP: Ed. da UNICAMP, 1997, p. 16-17.

Tradução: Eni P. Orlandi. Campinas: Pontes, 2003.

. A Inquietação do Discurso - (Re)Ler Michel Pêcheux Hoje.

MARINHO, Marildes (Org.). Ler e Navegar: espaços e percursos da leitura. Campinas: Mercado das Letras, 2001. Coleção Leituras no Brasil.

MORAES, A. S. et al Embrapa Pantanal: 25 anos de pesquisas em prol da conservação do Pantanal. Corumbá-MS, 2004. $<$ htttp://www.cpap.: embrapa.br> Acesso em 10 jul. 2004, p.06.

MUSSALIM, Fernanda. "Análise do Discurso". IN: MUSSALIM, F \& BENTES, A. C. (Orgs.). In _ Introdução à Lingüística - domínios e fronteiras. São Paulo-SP: Cortez, 2001, V. 2.

MUTTI, Regina Mạ . Varini. Análise de discurso e ensino de português: o que interessa ao professor. Revista Entrelinhas, 2004.

NEVES, Maria Helena de Moura (Org.). Gramática do Português Falado. 2. ed. Campinas: Editora da UNICAMP, 1999, V. 7, Novos Estudos.

NOGUEIRA, Albana Xavier. A linguagem do homem pantaneiro. Assis-SP: UNESP, 1989 (tese de doutorado).

NOGUEIRA, Albana Xavier. Pantanal - homem e cultura. Campo Grande-MS: Ed. UFMS, 2002.

ONG, Walter J. Oralidade e cultura escrita: a tecnologização da palavra. Tradução: Enid Abreu Dobránszky. Campinas: Papirus, 1998. 
ORLANDI, Eni Puccinelli (Org.). Gestos de Leitura: da história no discurso. 2. ed. Tradução: Bethânia S. C. Mariani (et al). Campinas: Editora da UNICAMP, 1997.

Campinas: Pontes, 2000.

Análise de Discurso: princípios e procedimentos. 2. ed.

OSAKABE, H. Argumentação e Discurso Político. São Paulo-SP: Kairós, 1979.

PÊCHEUX, M \& FUCHS, C. A propósito da análise automática do discurso: atualização e perspectivas. IN_ GADET, F. \& HAK, T. (Orgs.) Por uma análise automática do discurso. Campinas-SP:ed.UNICAMP, 1990, p. 166-167.

. Semântica e Discurso: uma crítica à afirmação do óbvio. 3 . ed. Tradução: Eni Pulcinelli Orlandi (et al). Campinas: Editora da UNICAMP, 1997a. Coleção Repertórios.

PINTO, Maria Leda. Cotidiano e Representação do Pantaneiro nas Narrativas Orais. In _ ANASTÁCIO, Elismar Bertoluci de Araújo; MALHEIROS, Márcia Rita Trindade L; FIGLIOLINI, Márcia Cristina Rocha. Tendências contemporâneas em letras. Campo Grande: Ed. UNIDERP, 2005, p. 267-78.

POSSENTI, S. Discurso, estilo e subjetividade. São Paulo-SP: Martins Fontes, 1988.

- Teoria do Discurso: um caso de múltiplas rupturas. In

MUSSALIM, F. \& BENTES, A. C. (Orgs.). Introdução à Lingüística - fundamentos epistemológicos. São Paulo: Cortez, 2004, V. 3.

1988.

. Discurso, estilo e subjetividade. São Paulo: Martins Fontes,

PRETI, Dino (Org.). Análise de Textos Orais. 5. ed. São Paulo: Humanitas, 2001, v. 1, Projetos Paralelos.

Conversação. São Paulo: Contexto, 1991. Temas Atuais.

PROENÇA, A. César. Pantanal - gente, tradição e história. 3. ed. Campo GrandeMato Grosso do Sul: Editora da UFMS, 1997.

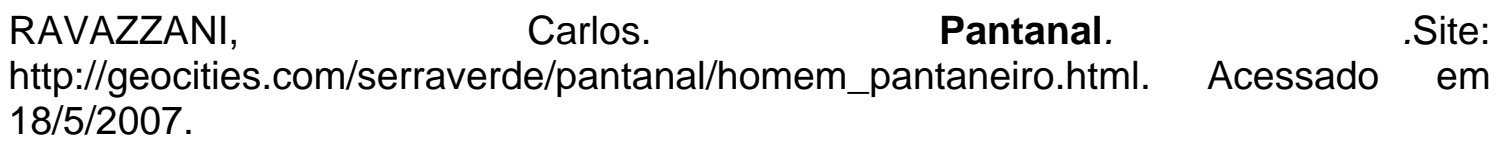

SAUSSURE, F. Curso de Lingüística geral. São Paulo: Cultrix, 2000.

SCHNEIDER, Marlene. Um olhar sobre os caminhos do Pantanal sul-matogrossense: a toponímia dos acidentes físicos. Três Lagoas/Mato Grosso do Sul: UFMS, 2002 (Dissertação de Mestrado). 
SILVA, M. da Conceição Fonseca. Os discursos do cuidado de si e da sexualidade em Claudia, Nova e Playboy. Campinas-SP: Unicamp, 2003 (tese de doutorado).

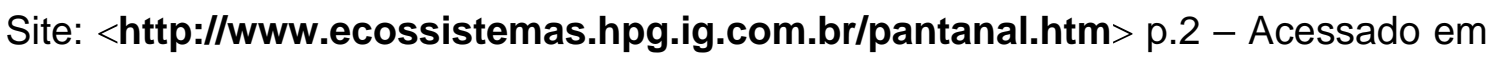
07/05/2005.

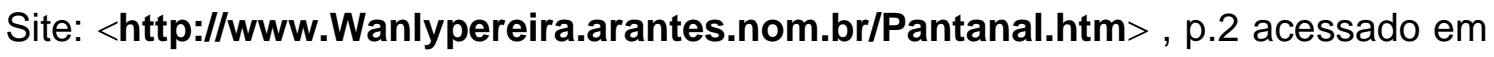
$03 / 09 / 2004$.

Site: Pantanal - Patrimônio de reserva natural da Humanidade (UNESCO) -

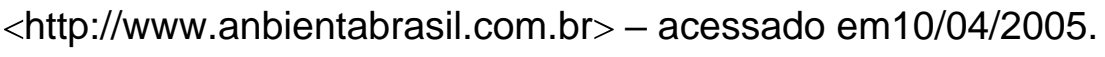

Site: <http:/ipantanalms.tur.br/habitats.htm > $>$ - acessado em02/08/2004.

SOUZA, Lécio Gomes de. História de uma Região: Pantanal e Corumbá. São Paulo-SP: Editora Resenha Tributária Ltda, 1973.

VILELA, Edviges M.P. Fábula de Millôr - O desmantelamento de uma ideologia. Site: 'http://www.filologia.org.br/vicnlf/anais/caderno03-07.html _i - acessado em $21 / 07 / 2005$.

WEINGARTNER, A. A. S. dos. Movimento Divisionista no Mato Grosso do Sul. Porto Alegre-RS: Ed. Est, 1995.

ZUMTHOR, Paul. A Letra e a Voz: A “leitura" medieval. Tradução: Amalio Pinheiro, Jerusa Pires Ferreira. São Paulo: Companhia das Letras, 1993. 
ANEXOS 


\section{ANEXO 1 - ROTEIRO DE CONVERSA COM OS PANTANEIROS}




\title{
ROTEIRO DE CONVERSA COM OS PANTANEIROS
}

\section{1) FAZENDA VISITADA:}

Identificação (nome, época de fundação, proprietário,

\author{
rápido histórico da fazenda)
}

\section{2) PANTANEIRO(A)}

a) Dados pessoais - apresentação: nome/idade/sexo/grau de escolaridade/profissão (peão, capataz, esposa deles - cozinheira, etc), nasceu nos pantanais e/ou há quanto tempo vive nos pantanais, constituição familiar (filhos, esposo(a), moradia, as relações familiares), o que você faz em casa: gosta de cozinhar? Gosta de trabalhos domésticos? Cuidados com as crianças..., a casa...?

b) Trabalho :

1) Conte o seu cotidiano na fazenda: o que faz desde a hora em que se levanta até ao anoitecer.

2) Como se sente morando (vivendo) neste lugar? Como encara essa vida? Gosta dela? 
3) atividades realizadas na fazenda; convivência com as pessoas que trabalham junto com você ( colegas, capataz, patrão); diversão?

\section{c) Como se situa e/ou atua nesse espaço:}

1. Pretende mudar de vida? Por quê?

2. Gostaria de ter sua própria fazenda e/ou morar na cidade? Por quê?

3. Qual é a sua relação com os vizinhos?

4. Sentimentos: tem algum medo; como lida com isso; você é feliz vivendo aqui?

5. Conte um fato que aconteceu com você e que foi marcante em sua vida.

6. Você é feliz?

7. Para você o que é felicidade? 
ANEXO 2 - NORMAS PARA TRANSCRIÇÃO 


\section{NORMAS PARA TRANSCRIÇÃO}

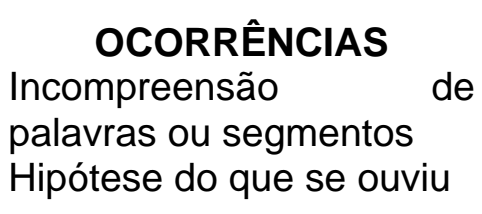

Truncamento (havendo homografia, usa-se acento indicativo da tônica e/ou timbre)

Entonação enfática

Prolongamento de vogal e consoante (como s, r)

Silabação

Interrogação

Qualquer pausa

Comentários descritivos do transcritor

((minúscula))

Comentários que quebram a seqüência temática da exposição desvio temático

Superposição, simultaneidade de vozes

Indicação de que a fala foi tomada ou interrompida em determinado ponto. Não no seu início, por exemplo.

Citações literais ou leituras de textos, durante a gravação
SINAIS

(hipótese)

maiúscula

:: podendo aumentar para:.:.:

ou mais

$?$

$\cdots$

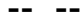

ligando as linhas
(...) nós vimos que existem....

EXEMPLICAÇÃO

do nível de renda... ( ) nível de renda nominal... (estou) meio preocupado (com o gravador)

E come/ e reinicia

porque as pessoas reTÊM moeda

ao emprestarem os... éh::.. ... o dinheiro

Por motivo tran-sa-ção e o Banco... Central... certo?

são três motivos... ou três razões... que fazem com que se retenha moeda... existe uma...retenção

((tossiu))

... a demanda de moeda -vamos dar essa notação demanda de moeda por motivot

A. na casa da sua irmã

B. sexta-feira?

A. fizeram -lá

B. cozinharam lá?

Pedro Lima... ah escreve na ocasião... "O cinema falado em língua estrangeira não precisa de nenhuma baRREIra entre nós"... 


\section{OBSERVAÇÕES:}

1. Iniciais maiúsculas: só para nomes próprios ou para siglas (USP etc);

2. Fáticos: ah, éh, ahn, ehn, uhn, tá (não por está: ta? você está brava?);

3. Nomes de obras ou nomes comuns estrangeiros são grifados.

4. Números: por extenso;

5. Não se anota o cadenciamento da frase.

7. Podem-se combinar sinais. Por exemplo: oh:....... (alongamento e pausa).

8. Não se utilizam sinais de pausa, típicos da língua escrita, como ponto-e-vírgula, ponto final, dois pontos, vírgula. As reticências marcam qualquer tipo de pausa. 
ANEXO 3 - DEPOIMENTO 
D1 - HISTÓRIA DE VIDA DO SR. S. N. C.

Idade; 45 anos

Residência: Fazenda Paloma - Pantanal Alto

Duração da gravação: 70 min

Data: 28/08/2004

Meu nome é S. N. C. ... aí eu comecei a trabaia no Pantanal por volta de doze... doze ano... treze ano já comecei a trabaia no Pantanal... mas trabaiava em cima de:.... da área de campero... né? Aí eu enjoei de trabaia no campo... tá? dos treze até os dezessete

5 ano... eu trabaiei no... no campo... mas não... nunca tive acidente no campo... aí eu larguei de trabaia no campo e passei a trabaia com trator... aí minha vida foi só trabaia no Pantanal com trator... éh:..... puxá CARga... levá CARga... duma fazenda pra otra... as vêis... a gente trabaiava o dono da fazenda tinha duas... três fazenda...

10 então... a gente tinha que locomove de uma pras otra pra levar CARga, né? são mantiMENto... as vêis arame... éh material... que as vêis tava construindo e a gente tinha que levar... e daí que a gente começava a sofrer MAIS que a vida de campero... que as vêis a gente achava que a vida de tratorista era mais fácil e não era...

15 era mais difícil... mais difícil porque a cavalo você não atola e com trator você atola... né? com trator você atola e as vêis fica o dia inteiro... a noite inteira com ele ali... sem poder sair... e de a cavalo não... se você saiu cedo... você tem certeza que à tarde você tá na sua casa... e a trator não... porque o trator não tem como você tira

20 ele do lugar e pôr no outro... a não ser ele mesmo sair... né? então é muito difícil a vida no Pantanal nesse sistema... pra quem trabaia... todas as partes que você trabaia no Pantanal é difícil... né? não tem nada fácil... não existe nada fácil... porque só... o Pantanal é uma área muito grande... é uma área muito grande...

25 então é difícil uma fazenda dentro do Pantanal... né? há quinze... vinte anos atrás que ela tinha três mil hectares... ela sempre é de QUArenta mil hectares... CINqüenta mil hectares... então pra você locomove... as distâncias são muito grande... você teje de a pé... você teje de a cavalo... você teje em cima de um trator... tudo é

30 longe... tudo é longe (disso aí)... né? aqui pra cima da serra você sobe aí:....... numa fazendinha de três mil hectares... você anda o dia inteiro nela... de tarde você tá na ( )... no Pantanal você anda o dia 
inteiro numa invernada e não chega no fim dela... são só fazenda grande... então as vêis você... dum retiro pro otro... você vai dum retiro... você sai da sede pra ir num retiro vinte quilômetro... né? se tá na seca você faz ele com duas hora... se tá na época das águas... você vai fazer aí... o dia inteiro e ás vêis não chega... você atola... você desatola... você atola e vai indo até você chegá no seu destino final... né? então... é por isso que eu falo que é difícil...

40 então... as coisa lá não é fácil que nem as pessoa fala "ah... o pantaneiro tem uma vida feliz... o pantaneiro éh... éh:..... tranqüilo"... tranqüilo na realidade... mas a vida deles são muito difícil... não é fácil não... a vida deles... se uma criança as vêis fica doente... uma pessoa TARde da noite... como é que você vai saí? a noite avião

45 não baixa... né? então você tem que se sair... se mover de uma carreta de boi... você tem que sai em cima de uma carreta de trator... né? você sabe que você sai... agora você saber que você vai chegá lá... tal hora... isso aí ninguém sabe... em cima duma condução... isso aí não tem previsão... né? são três tipo de

50 recurso... são trator... né? cavalo... né? e barco... que você vai sair de lá... senão você não sai NÃO... as vêis no começo do Pantanal... quando você pega o MEio do Pantanal... são só esses três pra locomover... as vêis a pessoa fica doente... não tem (otro)... não tem um trator... não tem nada pra levar ele... vai ter que sair uma

55 pessoa de a cavalo... até chegar numa fazenda que tem um trator... pra podê avisá aquela pessoa... pra aquele trator í LÁ naquela fazenda... pra pegá a pessoa... pra trazer até onde tem um ponto de carro que pega a pessoa pra levá (pro hospital)...qué dizê que aí você já perdeu tempo... se é um causo de salva vida... você

60 praticamente já tá... bem mal... né? que da hora que você gastou duas horas de a cavalo pra í até nessa otra fazenda... se tivesse um jeito de você saí de lá... você tinha duas hora pra frente... né? você já tinha duas horas pra frente... então éh... por isso que eu falo "o Pantanal éh bom... éh bom... mas a dificuldade lá não é fácil... não é 65 fácil mesmo"... mas têm pessoas... lá dentro que:.: ... se você dé uma vida melhor pra ele... pra fora... ele não sai... ele NÃO acostuma... que ele já nasceu e criou em cima daquilo ali... a dificuldade pra ele... éh só a felicidade dele... mas não todos... não todos... então... pra mim mesmo... eu... eu fui trabaiano... trabaiano

70 e fui veno que aquilo ali... não éh uma vida que a gente queria pra gente... não éh uma vida... você trabaia no Pantanal... você sofre... sempre... -- anoitece... hoje né?-- o Pantanal já quase... cinqüenta por cento dos lugar já tem luz... antigamente não tinha... né? 
antigamente não tinha... então você no escuro... é de lamparina... 0

mosquito... mosquito... hoje no Pantanal... noventa por cento... TUdo tem... né? então as criança tudo éh:.. (ferrada)... tudo éh manchada dos mosquito... né? num tem uma no Pantanal que num tenha mosquito NÃO... você trabaia lá... por causa da sobrevivência... da sobrevivência você trabaia... tem a farTURA... tudo éh à vontade... tudo éh à vonTAde... você num tem horário de serviço... hoje você pega quatro hora da manhã... no otro dia você pega as sete... então cada um trabaia em cima do horário deles... né? se chega três hora da tarde... você já tá... já paro... tá entendeno? Não é que nem uma firma... né? que você tem que

85 pegá sete hora... largá onze hora... lá NÂO... lá cada um trabaia conforme QUÉ... então num/por isso que eles acha bom isso aí... eles num éh preso... então se você precisa sair "ó eu vô hoje na cidade" o patrão - - você fica quatro dia lá - - ele não te desconta nada... ele não te desconta NEM... nem um dia... chega no fim do

90 mês... seu pagamento tá... em cima daquilo ali... daqueles quatro dias... cinco dia que você ficô pra cidade... aquilo ali não éh descontado nada... e se você trabaia pra fora e se você faiô dois dia... isso vêm descontando... isso vem desconTADO... então é por isso que as vêis a gente fala que o Pantanal éh bom... tá? mais...

95 que não é fácil...(e... o aprendizado do senhor... como é que foi? lá tem que aprende:::.. já ir sabendo as coisas? como é que se aprende?) NÃO... a gente se aprende assim... tem uma pessoa que:.... éh/você trabaia... vão supor no campo primeiro né? eu trabaiei... comecei a trabaia com doze ano... então... você num

100 tem... você num sabe trabaia... então... você vai aprende oiando os zotro fazê... conforme o zotro vai fazeno... então... o própio capataz... que (fala) que é da fazenda... ele apóia você... "vai lá... joga o laço... laça... pega... maneia né?" pra você í aprendeno... então você já aprende trabalhano... você já aprende trabaLHANO...

105 aprende fazê tudo... ( ) éh... se aprende tudo que é feito... em cima do campo... é os própios campeiro que faz... ele aprende faze um (arreio)... aprende trança o laço... aprende fazê um:... ( )... aprende tudo... então nada éh fácil pra ele... né? ele mesmo faz a traia dele... se você... vai aprende trabaia com trator... se eu com treze...

110 dezessete ano... eu num saBIA... então o que eu ia sê? ia trabaia de ajuDANte... você começa trabaia de ajudante daquele tratorista... você tá entendeno? ai você vai trabaiando de ajudante... aí você vai oiano ele... ele trabaia... muda marcha... pára... sai né? aí você pede pra ele "deixa eu leva um pouquinho?" então você vai pegá... 
115 como você vai pegá? você vai pegar nos lugar bom... porque se ele te dé num luga ruim... ocê vai ficar ruim... vai ser pra ele... porque você vai atola... vai fica mais difícil... então depois que você aprende nos lugar bom... aí você começa a:... dirigir também nos lugar difícil... pra vê se você tem capacidade de fazê o serviço que ele

120 fez... então você já aprende sofrendo... você já aprende trabaiando em cima daquilo ali que você aprende... né? então hoje... você passa num lugar difícil... passou bem... quando é amanhã... ele já não tem medo de te entregar o trator pra você í sozinho... porque sabe que você vai e VOLta... uma atolada... duas atolada... não vai

125 deixar o trator na estrada... você vai vim com ele... você vai desatolar... ocê vai sofrê até você voltar aquele trator pra trás... (ih... você faz isso com boa vontade?) boa vonTAde... tudo com boa vontade... e isso que ele num ajuda muito... você se vira... porque todas as vezes que cai numa dificuldade... e o próprio cara que é

130 profissional... tira você... você jamais vai aprende... tá entendeno? então ele vai 'NÃO... voCÊ tem que fazê assim"... ah mais... não... "faz assim que você vai sai daí" tá entendeno? agora se ele fizer... você não tá aprendeno... né? então... ele vai deixá você sofre um pouco... que é pra você aprende... pra vê se você tem paciência...

135 se você não é nervoso... que as vêis a pessoa começa mexe fica muito nervoso... ele já larga de mão... pega o caminho e vai embora e a... sua máquina ficou pra trás... por que se não? "ah:.... porque eu pelejei lá e não deu certo" mas como não deu certo? como é que o rapaz vai lá e tira e vêm? então a pessoa nunca pode fica 140 nervoso... todo serviço que você fica nervoso... você não... não faz mais... éh um aprendiZADO... tudo que você aprende no Pantanal é um aprendizado... porque se você não aprende... você num VIVI... você não vive MESMO... tudo é diFÍcil... né? você tem que ter MUlta paciência... né? você atola o trator... se você ficou nervoso... aí... se

145 o trator fica lá... ele fica:... você vai embora... que pra nóis num... que pra nóis... nada segura NÓIS... se você vem com trator bem... se não vem... você vem a pé... ocê vem por dentro d'água... rasgando água pela cintura... espantando jacaré... sucuri... mas você vem emBORA... por quê? porque você é CRlado e nascido

150 ALI... você não tem medo daquilo ali... né? você não tem medo...você tá vendo na sua frente três... quatro jacaré... você vai pra cima deles... eles que tem que saí de você né? então se você ficou nervoso... você vai larga o trator? você tem que tê muita paciência... tranqüilidade... para pensa... cuma que eu tenho que 155 fazê pra mim sai daí? até você achá um meio de você tirá a 
condução que você atolou... pra pode vim embora... né? então... é onde você vai pegano média cos patrão... (ah tÁ...) você tá entendeno? se você começá desisti... eles já te manda emBORA... né? você não SERve.. éh:... você não SERve... porque você vai

160 leva uma carga... principalmente de uma fazenda pra otra... hoje chegou a compra do mês... aí eles põem você pra levá essa compra lá num retiro... cinqüenta quilômetros... lá no retiro... as pessoas de lá num tinham mais nada o que cumê... já tinha acabado... então aquela compra tem que chegar LÁ... aí você atola o trator... fica 165 nervoso... volta pra trás... aquela compra vai chegar lá em três quatro dia... qué dizer que você não tá sofrendo... quem tá sofrendo é os otro que tá sem nada lá... então... aí tem que existir muita paciência... tranqüilidade... pra você consegui leva aquele que foi posto pra você até no destino final... né? tem que dá um jeito de se

170 leva lá... então a gente:... cada lugar que a gente trabaia... em todas as fazendas... cada um gerente... cada um capataz tem seu modo de lidar... tá entendeno? aqui um lida dum jeito "ah... eu vou sai daqui porque o capataz é ruim" as vêis você vai prum outro lugar... é pior ainda... o capataz de lá é mais rígido... né? ele não gosta de

175 brincadeira... ele quer as coisa certo... né? então você vai se habituano... a CAda tipo de fazenda é um tipo de... de mandato... né? cada tipo de fazenda... você trabaia com tipo de pessoa diferente... ocê tá entendeno? tem lugar... que você trabaia numa fazenda... que você vai sai com trator... eles qué que você sai

180 correndo... vai ligero e volta ligero... tem lugar que eles não gosta que corre... né? eles prefere que você vai mais devagar... então tudo você vai aprendeno conforme os... os líder da cabeça... que é o capataz... se não tem o gerente é o capataz... se tem o gerente... primeiro é o gerente... você vai lá... você vai degavar... você pode 185 chegá lá à tarde... já tem outros que fala "não... eu quero que você chega aqui meio dia" você tá lá... aí você tem que:.. apertá... então é muito difícil... se você vai sai duma fazenda pra otra pra/pra trabaia... eles vai pedi informação por que que você saiu de lá? o quê que você fez lá? né? "mas por que que ele saiu daí?" "ah... ele 190 saiu daqui porque brigou com capataz" "mas por que que ele brigou com capataz? o que que o capataz fez com ele?"... né? "ah... o capataz xingou ele" "ah... então ele não trabaia aQUI" porque hoje... muita gente éh::. quer tratar você com a ingnorância... e com a ingnorância hoje nóis não resolve nada... não éh mesmo? (então,

195 de vez em quanto existe esse tipo de... de desaforo?) que as vêis éh:.: eu... trabaio com trator... eu não sou tão bom como outro... 
as vêis... o otro faz aquilo ali... com maior facilidade que eu... mas eu num tenho a:..... a... - -vamos supô assim - - a tranqüilidade que ele tem... e tem muitos que não qué que tudo... que seja igual...

200 num existe tudo igual... num existe tudo igUAL... tem uns melhores... tem otros mais ruim - faz... mas mais devagar - tem outros que fazem aquilo ali... mas diferente... né? então... as vêis, aonde você sai duma fazenda pra outra éh através disso aí... né? e no campo a mesma coisa... - - se corre uma (rêis) - - as vêis tem

205 pessoa que com cinqüenta metro laça ela... tem otro que vai laçá com duzentos metro... né? então... as vêis o capataz num vê esse lado aí... ele qué que seja todo mundo BOM... num existe todo mundo bom... num existe todo mundo éh bom... tem uns que éh melhor... outros éh (pior)... mas que faz... faz... mas não com a

210 mesma ligeireza que um:... né? porque as vêis você fala assim 'ah... eu fiz tudo ligeiro' tá bom... tudo ligero você fez... mas se você for oiá aquilo ali... de tudo ligero que você fez... você vai aproveitar dez por cento... porque o resto ficou errado... né? só se você não (tem) aquela tranqüilidade... aquela... aquela coisa pra você fazê

215 aquilo ali... você tem que fazer... CAda vêis que você fazê você tem que fazer bem feito... bem FEITO... se você fizer bem feito... você vai te tudo... (...) éh:... que o patrão gosta... né? tudo que o patrão gosta... porque a nossa vida lá no Pantanal éh:..... num éh:... uma vida tranqüila... pra você sobreviver... tudo que você vai... vai pra

220 sobreviver... você tem que sofre... tudo você vai ter que sofrer... num existe nada FÁCIL... (e... a Caimã, como é que foi?...) foi na Caimã... na Caimã que eu fiquei cinco ano e meio... mas lá eu já era... -- conforme a gente vem aprendeno de tratorista... então... você vai aprendeno... você vai aprendeno... você vai aprendeno e

225 vai subino... né? vai subino... -- então na Caimã... eu já entrei como encarregado de máquina... daí eu comandava dezesseis tratorista... eu comandava lá... tudo éh:.... tudo era por minha conta... então... eu num precisava í no gerente pra saber se eles podia pegar um dia... se eles... precisava de um dia de forga... eles num precisava í

230 no gerente... eles podia vim ni mim né? se eles precisasse dum dia "não, você pode í... né?" o gerente num precisava nem saber quando... "o J. foi pra cidade?" "foi..." mandei porque eu sabia que ele podia te aquele dia de forga...né? então... tudo era comandado por mim... e graças a Deus... trabaiei cinco anos e meio... tive

235 pobrema com o gerente... né? com gerente tive pobrema... que foi a minha saída... nunca a gente é prefeito... um dia as vêis... você tá nervoso ele também... onde foi a nossa desavença... mas:... a gente 
tem que (caça jeito) pra fazer as coisa bem feito... pra você pode subi na vida... se você num fizé bem feito e com tranqüilidade...

240 você num sobe nunca na vida... nunca... nunca... nunca... ( ) de lá eu vim pra fazenda Estrela... aí pra... aí já foi em cima da (serra)... vim pra fazenda Estrela só que daí eu num era mais o encarregado.... eu já vim ser subordinado... né? eu já fui sê pião... lá já era outro encarregado que mandava ni mim... aí que trabaiei três

245 anos e meio lá... aí eles venderam a fazenda e eu vim pará hoje aqui... na Paloma. ( ) um ano e seis mês... já fez que eu tô aqui na Paloma... fez um ano e seis mês... (o senhor tem::. algum::.. 0::.. divertimento como é que é no Pantanal... como é que era lá... vocês têm momentos de::.. lazer... de::... como é que... como é

250 que isso funciona? ou é só trabalho? mesmo que ( ) do trabalho...) não... eles tem lazer... o lazer deles... éh hoje... éh o domingo "ah... tá tudo parado... vamos lá na fazenda... fazenda fulana lá brinca" de que que eles vai brincá? vai lá conversar... diverti... você tá entendeno? então... as vêis lá na... - - aqui nóis

255 somo quatro pião... lá éh mais três - - então num tem como você fazer um divertimento... um jogo de bola... com sete pessoa né? você vai lá... mas só conversá e falá das coisa... que você mesmo fez... ah... eu lacei uma vaca... eu atolei o trator... eu... eu montei num bezerro... eu... eu brinquei... montei num cavalo... então esse

260 aí é o divertimento deles... ( ) éh muito difícil... éh muito difícil... lá no Pantanal mesmo... é muito difícil festa... né? e se tem uma festa... as vêis... num é todos que vai... por exemplo um pai de família... tem uma festa daí::... cinqüenta quilômetros... num tem como ele í... porque num tem condução pra leva... então quem vai mais é a 265 rapaziada sortera tá entendeno? que as vêis... onde vai ter aquela festa... éh:.... carro num vai... só vai a cavalo... como é que um pai de família vai as vêis com três crianças... muié... tudo em lombo de cavalo... né? então... os rapaz sortero se locomove com mais facilidade... porque ele é sozinho... né? ele pega uma muda de

270 roupa... ponha num ( ) dele... ele vai com a roupa suja... chega lá ele toma banho... troca de roupa... no outro dia ele pega o caminho e vem embora... então... mais éh sortero... mais éh sorTEro... só participa mais os casado... éh... quando a festa éh na fazenda que você mora... aí os casados participa... já os outros que moram nas

275 outras fazenda vizinha... talvez já num vem também... que as vêis a festinha vai até uma hora... duas hora da manhã... aí você volta tudo a cavalo... com criança... duas hora da manhã pro seu... pra sua fazenda... então... talvez vai... talvez não... né? talvez "ah:.... 
vai lá numa festinha de aniversário... um:... um bolo que vai fazer"

280 então convida as fazenda... né? "vai lá" então você vai prum:... sonzero lá pra você escutá... até uma hora... duas hora da manhã e cada um vai pra sua casa... então se você tem família... como é que você vai volta as vêis uma hora da manhã com criança dormindo em cima de cavalo... né? que as vêis essa... esse dia que teve essa

285 festa o Pantanal tá cheio... né? não tem como você í de carro... não tem como você í de trator... só vai mesmo a cavalo... né? as vêis um trator num vai... né? porque éh:.... éh o campo das fazenda (então)... as vêis uma fazenda dentro do Pantanal... ela faz divisa com quatro... cinco fazendas... as vêis dez fazenda... então... 290 (talvez) durante o dia você encontra... com os outros... pessoa de lá... que você tá dentro do campo da fazenda... você passa na divisa... você vê uma pessoa do outro lado... aí você... — ah:.... lá na fazenda fulana vai te uma festa... então... através disso que vai a comunicação... as vêis... éh buscá uma (riculota) né? uma (risca)

295 que ele qué... dessa fazenda... que passô pra de lá... o capataz avisa... né? aí você vai lá e já sabe a notícia... que na outra fazenda da frente... vai ter uma festa... né? existe muito o rádio amador... né? em cima do rádio amador... que as vêis você tá falano e você escuta otra fazenda fala... você fala com ele "ah! aqui vai te uma 300 festa... fulano... você vem aqui... né?" então... você vai... a vivência é muito BOA... muito BOA... acho que o Pantanal... éh uma área do Pantantal que éh... vamos supô assim... ingnorância existe em qualquer lugar do Brasil... mas o pantanero... você pode andá dentro do Pantanal... não existe ingnorância... não existe

305 ingnorância... são as pessoas... tudo quanto éh lugar que você chegá... você é bem tratado... tudo lugá que você chegá... você é bem tratado... - (cedem a comida... cedem...) cedem a comida... se você chegá numa casa dum pantaneiro... a primeira coisa que ele pergunta pra você — você já comeu? você já armoçou? você

310 quer tomar um tereré? ele qué sê/ele qué fazê você feLIZ... aquilo ali pra ele éh um prazer... né? se as vêis... ali vai passá gente ali... cada:... quinze dia... vinte dia que passa uma pessoa... quando chega uma pessoa estranha pra eles éh um prazer tá recebendo dentro da casa deles... não é todo dia que eles vê aquele tipo de 315 gente... eles vê aqueles... aqueles deles ali... né? as próprias pessoa da comunidade do Pantanal... que todo dia... as vêis eles vê... as vêis duas vêis por semana ele vê... mas essa pessoa de fora éh difícil... por que... que uma pessoa de fora vai fazer no Pantanal? né? ela vai atrás de uma entrevista... vai as vêis... cruzá 
320 duma fazenda pra outra... as vêis quebrou o carro... ela vai de a pé... então... todo lugar que você chega lá... você tem (esse espírito)... você tem (esse espírito)... e o que eles pode cede pra você... eles cede... se você tá indo de a pé... eles te dão um cavalo... se tive um trator "não... pega fulano... leva lá na fazenda"

325 eles manda leva... então éh diferente de outros lugar... se você hoje... trabaia em cima da serra... ninguém te dá nada... se você pedi um favor aí... muita gente num faz pra você... se você quebrá um carro aí ó... e pedi pra uma fazenda í puxá pra você e levá até num recurso... ninguém LEva... e no pantanal... as vêis... se uma

330 pessoa anda aí... levando um trator que quebrou aí... as vêis... trinta... quarenta quilômetro... quanto custa isso? num custa nada... por quê? porque ele faz pra você hoje... amanhã você faz pra ele... então... são trocado... isso é trocado... né? ninguém cobra nada de ninguém... pra otro lugar que você fizer isso... eles só faz em cima

335 de dinheiro... só em cima de dinheiro... se você não pagá você não faz... e lá pra lá... não... éh... essas vantagem e pra lá ninguém cobra nada de ninGUÉM... ninguém cobra nada de ninguém... se precisá hoje... dum trator pra í trabaia numa fazenda vizinha... o fazendeiro "oh... vai lá e trabaia o dia inteiro pra lá" "quanto custa?"

340 "num custa nada" porque amanhã... ele vai... talvez ele vai precisá daquela fazenda... que você prestou um dia serviço pra ele... trabaia pra ele também... então... eles chamam... né? então chama... "você vem... trabaia" num custa nada... né? num custa nada... então você sai... fica as vêis quatro dias na otra fazenda... você não vai pagá

345 cama... você não vai pagá comida... você não vai pagá nada... se você precisa í naquela fazenda... vai acontece a mesma coisa com você... ninguém vai cobra nada... né? são áreas muito boas... NESse sentido né? mas:... falá que o Pantanal éh::.. éh:.. muito bom... muito bom... éh só pra quem é de idade... sessenta... setenta

350 ano... que nunca saiu dali... então... eles (gabam) aquilo ali... mas a próxima geração... dessa geração que nóis tamo hoje... pode... pode desce aí por baixo e preguntá... eles vai falá que tudo éh difícil... (hoje se trabalha com carteira assinada?...) HOje já assina em quase todo lugá... éh, quase todo lugá... mas 355 antigamente não... eu comecei cum treze anos... num exis/JÁ existia a carteira de trabalho... mas ninguém assinava... hoje eu tenho... vinte e dois ano de cartera... tô com quarenta e cinco... tenho vinte e dois ano de cartera assinada... por quê? porque você sai duma fazenda e entra na outra... ninguém assinava cartera... 360 hoje a lei... já tá obrigano qualquer lugá que você teje... a sua 
cartera seje assinada... toda/todo lugar... né? se você entrou hoje... amanhã a sua cartera tá assinada... já! (já tem como aposentar...) exatamente... se hoje... se você não tiver treze... quatorze ano de cartera assinada... dificilmente você vai consegui aposentá... se 365 você não tivé um padrinho pra te:... ajudá aposentá... dificilmente... se você tem vinte cinco... trinta ano de cartera... éh mais fácil pra você (aposentá)... porque você contribuiu cum INSS... éh... né? se você não contribui fica difícil... aposentá... mas é difícil... né? então... são as coisa que:...... hoje as vêis você preferi... as vêis...

370 ganhar MEnos num lugar... com a cartera assinada... que você vai segurá você e sua família... né? e aqui... você chega no Pantanal... ainda tem um monte de fazenda que num tem/tem pessoa aí que tem dez... doze ano que trabaia na fazenda e num existe cum carteira assinada... não tem ainda... né? por quê? porque eles num

375 liga... eles acha que aquilo ali pra eles éh uma felicidade... eles num pensam no amanhã... eles pensam o HOje... se ele comeu hoje... pra ele tá bom... ele não pensa no amanhã pra eles... né? eles acham que TOda vida eles vai manter e sobreviver no Pantanal... né? eles num vê a velhice deles... as vêis... tá chegando... eles 380 precisa dum lugar... melhor... se você trabaia vinte e cinco ano numa fazenda... num tem uma cartera assinada... como é que você vai ter o recurso pra saí do Pantanal pra comprá uma casa na cidade pra você morá? se o patrão não te der aquilo ali... -- éh por bondade -- você trabaiou vinte e cinco ano perdido... (e tem uns

385 que dão?) talvez dá... talvez dá... isso depende muito... as vêis você tá cum vinte e cinco ano que trabalha... você foi um excelente empregado... né? o patrão gosta de você barbaridade... cum vinte e cinco ano que você tá lá... você brigô... xingô o fazendero... você perdeu tudo os vinte e cinco ano... num éh mesmo? ele ficô bravo 390 com você... então... aqueles vinte e cinco ano de prazer... de... serviço prestado que você fez pra ele... ele não considera mais... ele considera a partir daquele momento que você xingô ele... (hum...) você tá entendeno? as vêis foi o quê? uma hora... as vêis meia hora de discussão... aqueles vinte e cinco anos já... já foi...

395 né? "ah... mais trabaiou vinte e cinco ano saiu e me xingo"... aí... num te dá nada... e as vêis tem muitos que fala "NÂO... nóis briguemo aquele dia... mais eu vou dá uma casinha pra ele" de seis... você tira um... que vai fazê isso pra você... então... se você tiVÉ a sua cartera assinada... você teria como... comprá su/sua 400 casinha... você tá entendeno? então... você perde muito sob isso aí... muito mesmo... (e a família... você constituiu como? em que 
lugar?) a minha famía... quando eu constitui ela... foi em oitenta e cinco... oitenta e cinco eu casei... casei em Aquidauana e trabaiava em... em .:.:cento e dezoito quilômetro na fazenda Paiaguás... cento 405 e dezoito quilômetro no Pantanal... na fazenda Paiaguás... aí nóis casemo... mudei pra lá... já num quis tê filho no primero ano... porque a dificuldade... eu num sei se vai sê bom... se num vai sê bom... e você com a muié... você sai de a pé... você chega... você tendo uma criança já é mais difícil... aí fiquemo um ano e oito mês

410 pra mim vê... também se dava bem... com patrão... (pra mim) não era mais só eu... aí eu já tinha uma muié pra me acompanhá... tá entendeno? eu sendo sozinho... eu vou lá... se num dé certo... em um mês eu vou embora... só que aí... eu chegava dentro da cidade eu tinha a casa dos meus pais... pra mim ficá... e eu casado... tinha

415 que tê a minha né? por muito bom que seja o sogro e a sogra... num é como você tá dentro da sua casa... então... já muda totalmente a diferença... né? muda e muda mesmo... aí é que eu... eu vim trabaiando... vim trabaiando... aí eu fui pro norte de Mato Grosso... lá pra lá de Coxim... pro Pantanal também... -- pra gente

420 podê/sempre eu pensei comigo... se você casou, você tem que tê casa... né? se você casou... é porque você saiu do poder do seu pai... né?-- aí eu fui pra lá... trabaiei mais de dois ano e meio lá no norte de Mato Grosso... ali perto de Rondonópolis... né? lugar BOM... já difícil pra locomove... nóis tinha... nóis tinha... são

425 trezentos éh::... quatrocentos e vinte quilômetro daqui lá.. pra nóis i vê meu pai e minha mãe... né? se nóis quisesse sai lá da fazenda... pra mim vê meu pai e minha mãe dentro de Aquidauana... são quatrocentos e vinte quilometro... né? então... pra você vê... tudo é difícil... tudo é difícil... tivemo dois filhos... a guria já fez dezenove e

430 o guri tem onze... onze ano... bom... aí eu tive essa guria com... em oitenta e cinco... aí dei um tempo... né? vamo pará... porque você fazê filho hoje é fácil... cuidar deles que é difícil... né? então... primeiro você vê se você tem condição de cuidar dos seus filho... aí sim... você faz o filho.... ele não pede para nasce... mas eles tem 435 que sê (espirrou)/então... pra você tê hoje cinco... seis... sete filho... num tá fácil... num tá fácil... é muito difícil... a guria tá no terceiro ano e o guri já tá na quinta... então... ele tem onze não... (estudam em Aquidauana?) NÂO... ela estuda no:.... no Taboco mesmo... no Taboco mesmo ela estuda aí e o guri já vai pra quinta série...

440 então... ela esse ano ela fecha o ensino médio... né? aí ela já vai prestá::: cursinho pra fazê o vestibular... aí ela vai segui o que ela... pretende sê né? mas por enquanto ela tá fechando o::: ensino 
médio do terceiro ano... agora.... esse ano ela... se ela não reprová ela... - - peço a Deus que não... né? que nunca reprovou - - ela 445 fecha o terceiro ano... eu já também fiz de tudo na minha vida foi... foi... fui até balconista ( ) pra tê os filhos estudano... porque lá no Pantanal é difícil escola... então... você não tem escola no Pantanal... né? se você tem um escola é até quarta série... aí da quarta série pra frente... você tem que saí... ou você deixa os filhos

450 sem estudá... ou... muda do Pantanal... eu mudei... mudei pra mim podê dá estudo pros meus filhos... eu já num tenho... né? meu estudo é pouco... então... pra sê uma família de tudo analfabeto... (riu) achei que:: num compensava né? então... pelo menos um da família tem que tê estudo... daí que eu vim:.. mudando... vim saindo

455 do centro do Pantanal... vim subindo mais pra frente... onde tinha até oitava série... aí onde tinha oitava série... se num tinha mais recurso pra mim... eu vinha pra cidade... éh:: eu trabaiava sozinho na fazenda... mandei minha família pra cidade... passando um MONte de dificuldade sozinho... pra manda a família pra cidade...

460 pra podê os filho estudar... né? aí eu trabaiava sozinho.... aí eu fui... aí eu fui enjoando de trabalha sozinho... aí que eu comecei a tra/pensa assim numa fazenda que tivesse condições de nóis morá junto... com a faMília estudano... tudo junto... aí... então... mais num é fácil... mas graças a Deus consegui a fazenda... que foi aí...

465 pertinho de:.: de Campo Grande... então tinha condução que levava até Campo Grande e trazia até a fazenda... aí nóis mudemo tudo junto... aí você fica em:.. harmonia com a família... né? que as vêis... aí você trabaiando no Pantanal... as vêis vinha em casa a cada quarenta e cinco dia... trinta dia... que as vêis na época que

470 chegava o fim do mês... deu vim pra casa... num tinha condução né? num tinha condução pra mim í... aí eu... num é o dia... você tá entendeno? ali num corre um ônibus... ali num tem um carro de linha... ali num tem nada... né? você fala "ah:... o fim do mês eu venho" "tá... então fim do mês você vem" aí quando chega o fim do

475 mês o patrão liga lá... "compra mais daí vinte e cinco dia mais pra frente" aí eu tenho que ficá lá... porque de a pé num tem como você vim... né? são duzentos... trezentos quilometros... aí... aí eu fui enjoando daquilo... aí eu falei "não, eu vou:... vou muda" aí eu mudei pra mais perto da cidade... onde eu vinha e voltava... porque 480 tem pelo menos uma... uma estrada... corre um ônibus... né? pra mim poder vim pra cá... mas mesmo assim a gente vai se enjoando... aí eu fui caçando um jeito de trabaia só onde tem escola... então... onde tivé escola... que cabe eu com a minha 
família... eu vo trabaia lá... se não tivé... eu mudo pra cidade... eu

485 mudo pra cidade... porque ali eu trabalho ali durante o dia e a noite to na minha casa... porque acho que uma família que:... trabalha um prum lado e outro pra outro éh::. dificilmente ela é feliz... dificilmente... tanto pro homem... quanto pra mulher num éh fácil... aí eu resolvi a subi a serra... falei "não... eu vou embora pra cima 490 porque... aqui pra baixo é difícil" (então, o senhor tem além desses sonhos que eu vi que o senhor já colocou aí... que... ter a sua casa, dos seus filhos estudar... o senhor ainda tem mais algum sonho que o senhor quer realizar?) tenho... é de formá meus filho.. (ah!) vou trabalhá pra podê formar (do jeito...) onde eles

495 qué chegar... talvez num... num realize o meu sonho mas tenho essa vontade... se minha filha quisé... "vou sê veterinária" eu queria éh tê condições de fazer ela sê o que ela qué... tá entendeno? isso é meu sonho... né? aonde você as vêis passa mais dificuldade... pra poder dá felicidade pros seus filhos... tá entendeno? EU... já tô no

500 fim da picada... né? mas queria dá:.... a felicidade pros meus filho... né? se amanhã ou dispois eles não vai recramá pra mim "ah... mas eu tinha vontade de sê isso e meu pai não deixô" daí... eu queria deixá eles formados... durante eu num formá eles... eu num tô sastifeito... eu num tô sastifeito... (o senhor tem algum tipo de

505 medo?) (risos) o maior medo da gente éh a própria vida... né? (risos) a própria vida da gente... a própria vida... porque o medo... eu acho que ele não existe... quem faz o medo é a gente mesmo... né? a gente mesmo que faz o medo... porque eu num vejo nada que dá medo... na fazenda não... na fazenda eu acho que nada dá

510 medo... o medo só existe na cidade... aonde você sai e você num sabe se você chega... né? na fazenda num existe esse tipo de medo... né? eu acho que... pra nóis aqui num existe medo... né? você pode tomá um susto... mas falá MEdo... medo mesmo... o quê que vai tê aqui pra nóis? nada... nada.... porque nóis num temo uma

515 área de bicho perigoso... nóis num temo uma área... de mata selvagem... onde a onça pode te ataca... nóis num temo aqui... né? de repente você vai/passa um bicho... você pode dá uma assustada... mas tudo em cima do normal.... agora na cidade grande... aí você tem que tê medo... ali sim.... ali o:.:. o perigo existe

520 na cidade... né? ali tem o perigo... pra nóis aqui não... pra nóis aqui nada dá medo... de jeito nenhum... (o senhor é feliz?) eu acho que eu sô... em cima do que nóis depende... eu sô... eu tenho a minha família né? sô feliz com ela... sô feliz com meus filho né? posso... queria dá mais felicidade... só que eu num tenho condições... né? 
525 nóis num temo condições de dá uma felicidade... as vêis pra família da gente conforme a gente qué... né? pra você tê uma felicidade... dá uma felicidade as vêis pruma família... um conforto de vida melhor... você tem que ganhá melhor e hoje em dia pra você ganhar melhor... num é qualquer lugar que... que as pessoa vai pagano pra

530 você... as vêis o que você merece né? as vêis você merece muito mais do que aquilo... mas ninguém te reconhece... se você num:..:: num... num buscá o que você qué hoje... ninguém reconhece o seu serviço... se pude baixá o seu ordenado eles baixa... mas levantá não... (risos) mas é a realidade... né? "ah... o fulano é bom... porque

535 eu trabalho com ele há cinco ano... ele é bom" Oia... aí você fala pra ele "eu vou embora" "mas porque cê vai embora?" "eu vou embora porque o ordenado tá poço" "então... você vai embora... porque aumentá pra você eu não vou aumenta" então... você num é bom... você tá entendeno? então... você num é bom... porque se você

540 fosse bom ele aumentaria seu ordenado e num deixava você saí... então... você é bom durante você tá trabaiano... a partir do momento que você não qué trabaia em cima do que eles qué... você tá dispensado... você tá entendeno? então... não existe pessoa boa... né? ah... a pessoa é boa... trabalhou lá há dez ano lá... a

545 pessoa é boa... se você pedir um aumento pra ele... ele vai arranjá outro que trabaia mai/MAIS barato que você... porque o custo de vida hoje tá muito duro e desempregado tem muito... se eu num quero outro qué... (o qui é a felicidade para o senhor?) eu acho que a felicidade pra mim éh:.: você vive bem... né? você vive bem...

550 você sê uma pessoa boa... né? se você num seje muito ingnorante com as pessoa... você tratá todo mundo bem... as pessoa te trata bem... acho que aí é a felicidade de você... então... toda vez que você recebe... você recebe bem... você chega numa casa... você é muito recebido... então... éh:.: a felicidade... porque a partir do

555 momento que você seja uma pessoa fechada... né? que não se dá com todo mundo... você:: éh::: dificilmente vai tê felicidade... você recebe uma pessoa alegre na sua casa né? aí... éh a felicidade da pessoa... eu vejo por aí. 
ANEXO 4 - DEPOIMENTO 
D2 - HISTÓRIA DE VIDA DO SR. J. Q.

Idade: 70 anos

Residência: Cidade de Aquidauana

Duração da fita: 50 min

Data: 02/10/2003

A gente morava no pantanal... pantaNAL alto ... não... pantanal... baixo... depois de muitos anos eu fui morá no pantanal baixo... então:: minha mãe morreu muito cedo... eu tinha de certo o quê... uns cinco... seis anos... eh:.: meu pai estraviou no mundo como diz o...eh...né? o caboclo... (ele) suMIU... ficou desorientado:.... (tossiu):..... então:.... até me emociona... sabe?...éh:... éh:.....aí... aí... a gente foi morá com a vó... minha vó era uma gaúcha MUlto trabalhadeira... MUlto dinâmica...juntô todo mundo num lugar só... aprendemos muita coisa com ela... ajudávamos ela fazer flores (sabe?)... pra podê ganhá o pão... (e) teve

10 muito ajutório... do Cel. Z. (esse povo antigo aqui) ajudou muito ela porque eles eram do Rio Grande... né?... então:... eles ajudaram muito a gente... aí... depois de muitos anos meu pai a/(casô) apareceu eh:... aí já apareceu com uma mulher...e essa mulher nos amparou... (porque)... os macho - - vamos dizê assim - - os guRl... fomos criado com o papai...

15 e trabalhando... desde dez anos... oito anos a gente trabalhô duro mesmo... fazia de tudo (na vida)... fomos casqueiro... naquela época tirava muita casca ...de madeira... de angico... pra vendê...... fazia contrato com a Noroeste... não sei com quem... curtume de São Paulo... né?... e a gente mandava pra lá... e aí ficamos muitos anos

20 trabalhando... mudamos pra Miranda-Estância... meu pai foi sê gerente na Miranda-Estância na época de Dom R. ... que era Companhia Inglesa... né?! a gente foi morá lá e lá a gente aprendeu de tudo... estudamo um pouco... eh:.: trabalhava... ajudante de bulicheiro... de loja... bolicheiro... naquela época chamava bulicho... então a gente era

25 ajudante de bulicho... e estudava e trabalhava no campo... era campero também.... aí ... passamos uns quatro... cinco anos... aí o meu pai saiu... saiu e foi trabalha com o genro dele que era o Dr. E. ... e a gente também trabalhando... e fomos mudá da... da fazenda Miranda-Estância para a Vazante... onde estivemos uns quatro anos também... fazia...

30 quase as mesmas coisa cuidava gado... rebanho... e domava muito... a gente domava naquele tempo diz que pra ganhá mais dinheiro... éh::... 
ganhava... oito rea/oito cruzeiro por animal que domava... né? ajudá salário... salário e ajudando o pai... que nóis nunca tivemo salário.... trabalhava muitos anos... até vinte anos eu trabalhei sem salário de

35 nada... ajudando o pai... ajudando (a turma)... aí mudamos pra fazenda ( )... mudamos pra fazenda Divisa... que ele comprou no pantanal lá do outro lado do Rio Negro e enchia demais... naquelas épocas... enchia MUlto... em cinqüenta e quatro mais ou menos... enchia demais... (nóis) levemos... uns sessenta dias pra saí daqui... de...de... da Vasante... pra

40 chegá nessa fazenda Divisa... e tinha que atravessá o Rio Negro... o rio Aquidauana e tudo tava cheio... então parava... dez dias... cinco dias esperá rio baixá ... córgo abaixá ... co... corixo... né? ah... lá é corixo... fazia... fazia:: estiva nas carreta... tudo com carreta de boi... não tinha... não andava carro... e então chegamo na fazenda Divisa e (fomos)

45 moramos lá uns Olto anos... mais ou menos... oito a dez anos... aí eu vim pro quartel... aí... do quartel aqui em Aquidauana... vim pra Aquidauana... servi o exército... éh:.: aí::: achei a dona $A$. ... namorei ela... e.. acabei casando... né?! e... aí a vida continuou... aí... daí já fui ser retireiro... já casei... já tinha mulhé... já podia ser retireiro... de

50 fazenda... fui... voltei pra Divisa... lá fiquei uns quatro... cinco meses... também era avião... avião ou a cavalo... aí viemos de avião pra fazenda São José... ele comprou a fazenda São José... e nós ... ficamos morando lá... eu como retireiro... Seu S. P. era o dono da São José... nessa época... (em) que o E. comprou... aí ficamos aguardando a

55 retirada de todos os objetos dele... né?... ficamos morando na fazenda... quando ele levou todo ga/du(essas) coisas eu fique de retireiro... tive uns três anos sozinho... só eu e a A. ... recebi um gado pra cuidar... um plantel de gadu Gír.. então... eu fazia tudo... eu era retireiro... era pião... era capataz... era tudo... fazia todo o serviço da fazenda... certo?... e o

60 meu tio era o gerente da fazenda... ele me deu uma égua velha e um burro aporriado e dez éguas pra mim adomá se eu quisesse andá a cavalo... bem a cavalo e eu domava e a dona A. me ajudava... ela.. segurava... eu montava... então nós só (tossiu).. a gente pedia a Deus pra ajudá pra não acontece nada... e aí eu morei lá... uns deis anos... na

65 fazenda São José... meus filhos nasceram todos lá... né... o/a M. ... a V. e o C. ... aí eu fui... comecei a enxergá e a ... querer mudar de vida... né?... aí eu/esse tio meu saiu da fazenda... (Pequi) aí o $\mathrm{E}$. me levou... pro Pequi... aí eu já fui ser capataz mais evoluído... né? mais... melhorado... ai passei a gerente... mas fazia tudo... gerente e capataz

70 naquele tempo e pião tudo era uma coisa só... trabalhava que só um condenado... né?... a gente trabalhava pra mostrá serviço... e tinha ambição de querer se gente... hoje em dia é difícil... né?... pião ninguém qué se gente... qué se/qué ganhá do patrão... qué por o patrão na justiça eh:.:. .... eh não... não qué nada... ele qué só isso... só prejudicá a quem 
75 dá pra ele a mão que mata a fome dos filho dele também... né?... que... eu sempre (digo) que o melhor emprego é de fazenda... o cara ... que se... se ele souber se tive ambição de ter alguma coisa... ele tem... porque é só ele economizá... ganhá ele ganha bem... coMlda ele tem... todo mês o patrão leva... carne ele tem na fazenda... ele não vai pra

80 frente porque ele não quer... moradia... água... luz... não paga nada... ( ) infelizmente... a nossa justiça é contra isso porque... eles põem você na justiça... né? (no Ministério) e você sempre é prejudicado... mas é um... negócio muito desagradável... - - e assim foi - - hoje... aí eu comprei uma fazendinha... comprei... antes disso eu tive um amigo que foi meu

85 segundo pai... chamava-se I. (T.)... esse homem começou a freqüentar a fazenda Pequi... arrendou/o Dr. E. arrendava gado pra ele a partir lucro e ele me dava muita orientação... ele era um senhor de Lavínia e tinha fazenda em Dourados... homem bom... caboclo... caboclo bom... ele começou a vida também... como se... serraria e foi adquirindo e tal e 90 ficou MUITO bem de vida... tinha fazenda... tinha dois avião... e aí (enfim)... tinha muita coisa... ele era muito bom.... ele me orientou... e que me ensinou também muita coisas... formação de PASTO... foi MEU professor... eh.:.: (tossiu) arrendei pra ele... nessa época... o E. ... que era meu cunhado... me deu invernada como deu pra todos os peões da

95 fazenda... também - - conseguido por mim - - cada pião tinha seu lote de gado... tinha ... teve pião que tinha até trezentas reses... eu era privilegiado cheguei a ter quinhentas... então eu dei pra esse I. T. arrendado... né?... ele me/levou pra/não sei pra onde... ele levou/arrendei o gado pra ele.. ele levou... e sempre ele me incentivava 100 “J. compra uma terra pra você" aí eu... por intermédio dele... ele me ajudando... eu comprei essa fazendinha... ele me levou de avião... falou "J. eu vou de avião... não tem jeito de eu ir por terra... vou... eu vou de avião... eu desço aqui e te levo... você escolhe uma fazenda pra você comprá por aí"... aí eu es...escolhi não ... num gosto de tá pulando de 105 galho... né? ele falou "(vamo) pode comprá que é boa né?" eu comprei... com sacrifício... porque:... eu não tinha capital... o único capital que eu tinha era essas quinhentas vacas com ele arrendada... aí ele falô "compra que eu... avalizo... eu vou nas costas" e adquiri essa fazendinha que eu tenho... e passô a chamar Repressa a minha 110 fazenda... aí botei o nome de fazenda Repressa nela... porque a primeira coisa que eu fiz nela foi uma... uma barragem de concreto porque ela era muito seca... ela tinha córrego... mas era seco... o córgo só enchia... num período assim... vamos dizer... de seis... sete meses no ano... aí eu fiz uma barragem... fiz um poço e aí... enfim fui fazendo as 115 coisas... fui formando e ela graças a Deus... com o ajutório de ... Deus e do meu filho... ela tá formada... né? eu tenho lá umas -- é pequena... fazendinha de novecentas hectares -- eu tenho umas setecentas 
hectares formadas de pasto... e vendi meu gado pra comprá... esta casa... o que eu tinha de sobra comprei a casa que eu moro... e com a 120 dificuldade de tudo fui tocando a fazenda... dei cem hectare pro vizinho que era dono da indústria... pra derrubá pra mim podê formá... prepara a terra... também éh:.: forçada pelo... C. meu filho... ele que sugeriu essa... esse meio... que nóis não tínhamos meio de ...diNHElro... né?! ... não tinha JEITO... então tinha que fazer qualquer coisa... achá um 125 meio... e o meio foi esse... eu lutando pro C. estudá... mas ele não queria de jeito nenhum... mandei ele pra São Paulo... pra todo lado... no Objetivo... eu era muito amigo/eu comprava boi pro Objetivo... J. C. (D. G.) que é dono do Objetivo... é meu amigo... ele era sobrinho do I. T. esse senhor ( ) e o O. era o geren/gerente do Objetivo... o Dr. O. ... ele 130 ... ele foi muito bom pra mim... mas o $\mathrm{C}$. não teve jeito de... de estudar... veio embora pra cá... eh... aqui eu ajudei ele a comprar uns tratores e foi começá a formá pasto pros outros... cem hectares... né?... assim... com grade... etc e tal... aí:: eu achava que não tava bem... que ele tinha que ser gerente... capataz de alguma faZENda... e nesse meio tempo eu

135 adquiri também umas tropas e comecei a viaJÁ... comitiva... éh:: eu achei que ia dá dinheiro... mas não dá... dá só pra comê... comitiva não dá dinheiro... ela dá léh um trabalho muito cansativo... muito sacrificado... né? a senhora já pensô você viajá aí sessenta... setenta dias no lombo do burro i comendo aquela comida... passando mau 140 tempo... chuva... é gostoso... é bom... é divertido que você vai cada dia num lugar... mas é sacrificoso -- quem num tem opinião num vai -- eu botei esse menino pra judiá dele pra vê se ele ia estuDÁ... eu larguei ele daqui... ele era novo ainda ele tava com os seus quatorze anu... botei ele -- ele era de opinião ele -- era um tempo frio (mês de maio lá em)

145 Maracajú o... o velho que tava cum/na comitiva com ele... ligô pra mim escondido dele..."seu J. vem buscá o C. ... ele tá mal... tá todo rachado... os lábio... o rosto dele" (disse) "tá bom... eu vô dá um jeito" aí peguei um irmão meu que tinha carro i fui atrás dele truce... ele num queria vim aí eu truce ele... mas éh... o negócio num é fácil... a vida éh

150 sacrificada... é gostosa... éh boa... a melhor/o melhor lugar que eu acho de fazenda é Pantanal... Pantanal... eu sô pantaneiro... gosto demais do Pantanal -- até sempre falo pra eles se eu tivesse jeito eu compraria uma fazenda no Pantanal (num é) venderia a minha aqui em cima que... aqui você forma... é melhor pra criá mais... engordá bem... mas você 155 tem qui viver limpando se você num limpa acaba sua fazenda e hoje a manutenção é muito cara -- eh o pantanal num precisa de nada você vive lá... éh:: só saber viver... a minha num é no Pantanal eu comprei essa fazenda aqui em cima... ela é começo do Pantanal... é cumecinho... é bem cumecinho mesmo... ela é aqui na beira do (Agaxi) 160 né? beira do (Agaxi)... o (Agaxi) é cumeço do Pantanal... (o senhor... a 
sua experiência primeira de trabalho é dentro...) eu me criei no Pantanal... eu sô pantaneiro nato... eu morei muitos ano no Pantanal... toda vida fui do Pantanal... todas as fazendas... Fazenda Divisa... Fazenda São José... Rio Negro... meu pai foi capataz na Fazenda Rio 165 Negro muitos anos... eu... morei ainda minha mãe era viva tava cum meus quatro anos quando eles eram capataz na fazenda Rio Negro... do seu O. ... seu O. R. ... esqueço o nome do pai do seu O.... éh.... o seu T. R. e o outro irmão dele esqueço... então ele era muito bom e muito amigo... o pai foi um homem muito campeiro... muito laçador e disposto

170 ele não tinha tempo ruim... era baguazeiro... gostava mesmo de trabalha e o C. puxô ele... esse menino meu o C. gosta mais... de tá nu... mexendo com essas coisas éh... pra ele num tem coisa melhor... assim também como eu gosto... eu adoro essas coisas... num faço mais - - eu tô com setenta ano né? - - num faço mais coisas porque::... a gente tem

175 que se guardá um pouquinho né... se não você vai e a coisa fica... (eh... a convivência... como é no Pantanal?) muito boa... o pantaneiro é um povo muito acolhedor... muito bom... você chega numa fazenda no Pantanal você tem tudo... era assim né? era assim/num sei hoje porque tá intrando muita gente de fora - - num é um pantaneiro - - ele num

180 conhece a dificuldade que tem o Pantanal... né? eles querem sê ruim... num qué deixa você posá... às vezes você chega numa fazenda que não é pantaneiro ele... - - não são todos - - têm alguns que não qué que pose com uma boiada... certo? não tê oferece um aconchego bom... né? você já comeu? quantas vezes você chega num pantaneiro ele...

185 primeira coisa que ele fala "você já comeu?" é desse jeito... e esse povo não... é deferente... ele ... se ele pudé vende ele vende pra você... QUANDO acontece de quere vende, tem muitos que fala "ah... é difícil trazê mantimento aqui pra fazenda... sai caro" não sei o quê... tal ( ) mas nu mais é uma... região muito boa.... ( ) depois que... que eu morei... que

190 eu moro aqui na Aquidauana que eu meio que parei de mexer um pouco com comitiva... eu tive que procurá uns meio pra mim ajudá a sustentação... né? que só da minha fazendinha num dava porque ela é pequena... a renda é curta... se eu fosse viver só dela... eu teria que vender ela pra mim sobreviver... né? porque ela é pequena e não tinha

195 acesso nessas épocas... agora hoje tem... né? e o que eu tinha de dinheiro gastei pra comprá ela... gastei pra comprá minha casa... enfim... até eu adquiri novamente pra forra o que/o que saiu... éh... o negócio num é fácil... e é só eu pra trabalhá... né? os filhos... as mulher casaram todas... o C. que me ajudava muito casou também... foi tomá conta de

200 fazenda... graças a Deus hoje ele tá bem... né? toma conta aí da Fazenda Caimã... éh... parece que é bem quisto lá na fazenda... parece não... é bem quisto porque o patrão dele cresceu bastante com as administração dele... né? em matéria de fazenda... gado cresceu muito... 
as fazendas todas formada... éh:..... vai levando... já tem uns princípios

205 bom... né? ele já comprou uma fazendinha... e vai indo... a senhora dele muito boa... (muito) trabalhadeira... (a família está sempre reunida?) sempre... sempre reunida... e eu fico meio chateado com eles... quando eles começam a... a querê brigá um com o outro né? eu acho que a família tem que ser unida né? tem que ser unida pra podê vence...

210 porque se não extravia um do outro num dá... e como eu tava te falando... quando o meu pai extraviô que minha mãe morreu... a gente extraviô que só filhote de ema... né? a ema quando .... quando desova que sai assim tem cinqüenta... cem filhote... né? aí... aí vai crescendo... vai extraviando tudo... quando você assusta sobra só o casal... o resto

215 (risos) o que bicho num comeu... duas que sobro... alguma -- mas sempre extraviado -- esparrama nu mundo né? é desse jeito... ( ) graças a Deus... eu sô feliz... que tenho meus filhos todos criado... né? vivo bem... graças a Deus... tenho ainda saúde pra trabalha (tá)... trabalho... o que eu posso fazê... até eu fico inquieto... quando eu tenho que... eu

220 tô à toa... não sei fica à toa... éh:.... eu quero... quero agir... quero/quero saí... enfim... éh... mexe o doce... né? como falam... tem que mexe o doce senão não vai... é hoje eu tô trabalhando com o L. ... é um senhor de São Paulo... L. N. N. muito bom... é por intermédio do (H. de A.) ele que me indicô esse senhor... aliás... ele indicô (os) eu... pra ele... e ele

225 pra mim... ele me procurou e a gente se introsô... que eu olhava a fazenda do $\mathrm{H}$. e passava na fazenda dele... desse seu L. e... aí coincidiu da gente se encontrá e eu fiquei trabalhando... ele não me chama de... de empregado... ele cha/fala que eu sô sócio dele... né? pra me leva mais pra frente... né?... pra (risos)... é pra me cativar de certo... né? é

230 porque... salário pequeno num...num dianta nada... a gente/eu trabaio demais... eu... tudo o que eu pego eu quero fazê e vencê... eu não fico apalpando... eu quero... quero mostrá serviço... até hoje eu ainda faço assim... eu não sei esconde da/das coisas... eu quero mostrá serviço né? e tudo o que eu faço... eu faço com amor... eu tando mun/(é)eu não

235 posso muntá a cavalo... eu sô proibido do médico... que eu tenho problema... mui/espinha quebrada e um mundo de coisa... né? coluna e enfim (até é o... é o...)/tudo... tenho três ou quatro operações e... mas mesmo assim... num... num tem tempo ruim pra mim... eu tandu muntado num cavalo... eu tô satisfeito... éh:.: considero isso a

240 felicidade... eu acho que a felicidade da gente... é vive bem... né? tê lugar pra você na velhice... de... ser amparado pelo menos tê uma casa... tê a família junto... num é? éh... o quê eu sempre falo pros meus filhos... "olha vocês hoje... vocês tão me/me agradam porque eu ainda posso fazê alguma coisa... eu não sei se quando eu ficá mais velho...

245 vocês vão fazê a mesma coisa comigo"... tenho medo disso acontecer... né? mas sô feliz porque todos eles... parece que me querem bem... né? 
e... eu ajudo o que eu posso eles... a M. -- por exemplo -- tem fazenda lá no (Mato Grosso) no Pantanal.... "oh... pai o senhor num vai lá" "(ah) minha filha tô trabalhando... não posso saí ainda... né?" e... vô tocando...

250 graças a Deus a gente vive bem... (onde moram os seus filhos?) todos vivem aqui éh... as duas mulher e o filho o C. ... ० C. é meio estouradão... mas é muito bom... estouradão assim... porque éh... éh... a maneira de ser... né? ele é caboclo... trabalha desde criança e você pra cê... você dá conta do recado... você tem que... não pode ser muito

255 fininho não... você tem que ser meio grosso mesmo... porque senão você... éh... éh:.... senão você apalpa e não vai.... (esta é a vida que o senhor sempre sonhou... sempre quis?) é a vida que sempre quis... porque eu não tive outro meio... né?... aprendi assim e assim eu vivo... e passei pro meu filho... né? meus filhos .... não tem outro meio... não tem

260 outro jeito... já tô... que que eu vô quere mais hoje... né? já tô com a vida terminando... setenta ano... que que eu espero disso... acho que nada... ( ) mas num tem dúvida que... a gente aprendeu a viver... tá aprendendo... continua aprendendo... porque tudo... cada dia tem uma coisa diferente... né? porque cada pessoa tem uma maneira de pensá... 265 e uma coisa pra... te ensiná... né? tem muito sabidão aí... que fala "ah... eu sei tudo" porque ganhô tudo de mão beijada... né? ou herdou de alguém... eu quero vê o caboclo começá du nada... né? e fazê alguma coisa... esse qui é (importante)... ( ) num tem mais ( ) por exemplo... a gente.... naquelas época que enchia Pantanal... né? a gente morava du

270 lado de lá do... do rio negro... então você pra vim na cidade... ou era avião... que era muito difícil naquela época... você num tinha contato... num tinha um telefone... num tinha um rádio... num tinha um nada... se você via um avião passa loNGE... você saia correndo... você precisando das coisas... você abanava com pano branco... né? pra vê se o avião

275 enxergava... pra desce ali pra te dá um socorro... uma coisa... era muito difícil... e ... aí depois com tempo... a gente já conversô com os pilotos pra eles sempre dá uma... uma... passar (em frente) em cima... se a gente quisesse alguma coisa... fazia esse sinal que eu tô falando... com lenço branco... (pedia ajuda?)... exato... é porque era raro avião 280 naquela época... era um ou dois avião só que tinha aqui ou intão o A. P. que foi um homem que era ... comprador efetivo da região pantaneira naquelas épocas... seu $A$. $P$. foi um homem também dinâmico... um homem muito bom... a gente trabalhô com ele... puxei muito boi pra ele também... esse homem era muito (bem) tinha um avião... de vez em 285 quando... raro... RARO... éh às vezes assim... cinco... seis meses ele passava uma vez... e a gente não vinha na cidade como vêm hoje... todo dia tá aqui... era num ano... um ano e pouco lá na fazenda... você num vinha na cidade... né? então... no/no caso de precisão era diferente... tô dizendo assim a vida... você passa lá um ano... um ano e 
290 dois meses... três... quatro... nove meses... era a média que você ... ficava na fazenda... não vinha.... então (no caso) numa precisão de vim... na... na cidade ... a gente surtia de carreta antes de enche vinha né? antes de encher... vinha com as duas carretas aqui na cidade... enchia as carretas de mantimento que você ia passar cinco... seis... sete 295 meses... com a quirera... cinco... seis... oito sacos de arroz... três... quatro de farinha... quatro... cinco de macarrão... cinco de feijão... ia indo... enfim você fazia o sortimento... esse negócio de temperinho... cebola... alho... esse você comia lá... cheiro verde... esse da horta que você plantava... mas num tinha... cebola... num vai durá? num dura...

300 né? num durava... ela dura aí quinze... vinte... um mês no máximo... aí apodrece... então num tinha/o tempero nosso era o tempero de casa de fazenda... cansei de... de fazê isso com o velho meu pai... a gente vinha... ele era o cacique... era $0 . .$. o patrão do negócio... né? então... a gente vinha com ele... fazia o bota fora dele até um ponto determinado...

305 assim que não tinha perigo mais pra frente... vinha... sempre era eu... eu era o mais velho dos irmão... né? eu vinha... eu ou o outro irmão ou um peão bom... fazia bota fora dele... atravessá aqueles curixo... aquelas vasantes... nadando... bola à pé e tal... atravessá o rio negro... a barra... largava ele aqui na Costa Rica... ele vinha pra Aquidauana... né? no

310 caso de precisão... aí... ele largava o animal dele... em qualquer lugar do retirinho... -- por exemplo -- era um ponto de referência... aí... depois a gente pegava o animal... ou ele ia de condução ou chegava até Aquidauana de a cavalo... né? se ali já... aí nu retirinho sempre já tinha mais facilidade... ali já... a condução de vez enquando já vinha... o

315 senhor S. P. tinha sempre um carro... ele era muito amigo... ele era primo irmão do meu pai... sabe? eles gostavam demais do meu pai... é gado por exemplo... você precisa de mata um gado no frigorífico aqui... você ... tando cheio... num tando cheio... tinha que vim... então... era uma... um dos sustos que a gente sempre passava... você nadando com

320 o gado... aquilo é um perigo... nadando... né? o rio negro quando enche ele emenda com o aquidauana e vem até aqui na... na... na Costa Rica... aquilo é um mar só de água... e nada de tê curixo... nada... a gente vinha/fazia pelota das... das mala... pra num... num... num rodá... fazia aquela pelota... amarrava na garupa... trazia ela... dava um jeito de

325 trazê... pra num se molhá todo... até a roupa né? enrolava num plástico... numa capa... num negócio e vinha nadando... deixava um pouco do pelego... vinha só com um peleguinho... éh... éh era dificultoso... não era fácil não... (e era bom?) mas ah... num tem dúvida... aquilo pra nóis era uma farra... era um negócio gostoso... você

330 fazia aquilo com prazer... né? com prazer... éh:: ... ganhava 5000 mil réis por mês (risos) é... era mil réis... né? naquelas épocas... então... e hoje você pra achá esse tipo de gente... peão... você tem que pegá os velhão 
ainda... e alguns novo que ainda aprendeu... ainda... né? que tá fazendo essas coisas... mas é muito difícil... mas é gostoso demais... muito 335 bom... é um/éh uma felicidade você tá mexendo com aquilo né? aqueles negócios... aquilo... éh... éh:...... depois você conta no galpão... hora que você vai tomá mate de madrugada ou então de noite... depois da janta... a pessoa tá desinciliando o cavalo... e tal... tá contando as histórias... "poxa...você viu aquela hora que afundo... fulano saiu lá na frente... né?

340 aquele boi que ia rodando... se viu o J. saiu nele lá e ... pegô o boi... fez o boi voltá na/no gado" enfim... é muito gostoso... é uma felicidade a gente mexe assim com gente prática e gente boa... né? quando você pega uma turminha ruim... é duro... você trabalha dobrado... eu sempre falo... quando eu era mais novo... eu falei "eu trabalho por três peão...

345 pode deixá por mim... que dou conta... de três" (risos)... é então... é desse jeito... é. 
ANEXO 5 - DEPOIMENTO 
D3 - HISTÓRIA DE VIDA DO SR. R. O.

Idade; 45 anos

Residência: Fazenda Santa Emilia - Pantanal

Duração da gravação: 50 min

Data: 18/06/2004

Meu nome é R. O. né? tenho quarenta e cinco anos... sô criado aqui no Pantanal... então... nasci na Nhecolândia... me criei... (não) me criei quase lá né? aí meus pais mudô pra cidade... aí nós fomos pra cidade.... aí meu pai foi trabalha de charretero... aí foi começando a vida e nóis/e nóis estudava... até o primeiro... segundo anos... éh... tinha o primeiro ano A né? é... e o (segundo)/estudei muito poço... eu só escrevo o meu nome... mas eu conheço muita letra .... eu não sei é juntá... é formá as palavras... você sabe? então... eu/daí nóis fomos para cidade e fiquemo pra lá... o meu pai trabalhando de charretero e ... ele só tinha um lado da

10 perna dele... ele quebrou a perna ali na fazenda Jurumi... ele tinha dezenove anu... mas nem... trabalhando nu campo... um touro trompo na perna dele.... e quebrô... mas num tinha nem nóis ainda... num tinha ficado com mãe... nada...num tinha se ajuntado (risos)... aí...depois que se ajuntaram que ele ... (éh) somos entre sete filho...mais já perdimu

15 dois irmão... os mais velho nós já perdimus... (um nós távamos inda aqui)... e duas mulher e... (deixa eu vê quem mais) J. ... M. ... M. ... Z. e eu... eh as mulhé... que é $D$. e $D$. ... eles foram criado tudo na fazenda também... mas o patrão que criou... deu tudo pra eles... eles morava com a patroa.... (é Pantanal) na... eles foram criados aqui na... na

20 fazenda Barranco... Barranco não... éh:.: Porto Ciriaco... é desse R. também... (Seu S.) aí...depois eu formei a minha família... até já não me lembro mais (risos)... quando... eu sei quando eu fiquei com a minha mulhé nóis amiguemo... né? ela tinha quinze anos... eu tinha dezenove anos... lá na Caimã...- - era Miranda-Estância antigamente - - lá nóis

25 fiquemo por lá... eh se ajuntemo eh fomo mora junto... fiquemo QUAtro anos ... éh::: ajuntado depois de quatro anos nóis casemo... aí depois que nóis casemo ... aí ... não deu mais certo (fico ao contrário)... nóis tivemo ... trêis filhos... dois guri tão com a mãe deles ( ) lá pro lado de Aquidauana pra lá ... ou:.: pra Campo Grande ... pra lá de Campo

30 Grande ....trabalha em fazenda... ela é cuzinhera né? agora o marido trabalha em fazenda também como campeiro (como diz o outro)... faz tempo já que não vejo meus filhos... só via o mais velho que ele tinha/(de vez em quando tava) aí na cidade agora num ta... tá pra fazenda... tá cum a mãe dele (tá) então sempre que ele ia/ que eu ia daí 
35 da fazenda... trabalhava aqui na... fazenda que éh do (M.) R. sempre ele tava por lá... (eu encontrava)... ele ia lá ... sabia que eu tava lá... in:.:: (então) ia lá... aí nóis encontrava... mas os outros eu não via mais ... tá cuns três anu que não vejo eles ... mas já conversei pelo telefone cum eles... ( ) telefone... éh:.: que agora eu perdi o número do telefone (risos)

40 extraviô o número do telefone e não tive mais contato com eles... mas tão na fazenda.... aí não casei de novo... não (depois dessa)... ah:.: não deu mais certo... então... (eh:.: fico igual a tal da) guaiaca velha... escondendo... perdido por aí... dentro do brete... é um... um/éh::: mesmo que um porco (cachaço)... um bicho macho né? que vive/ele fica

45 sempre sozinho né? ele não fica misturado no meio dos porco... nem nada... éh:.: se sente assim/éh sozinho... mas vivo minha vida tranqüilo graças a Deus... trabalhando... a minha profissão é trabalhá no campo... é lavrador né? na carteira minha (é) assinado como lavrador... mas eu faço tudo quanto que é serviço... eu mexo com trator ... dirijo a

50 caminhonete... também eu dirijo... mas num tem coisa assim né? tem sempre mais é campo... é com lida de gado né? AGORA que eu vim pra cá que... eu tô mexendo com o negócio de turismo e... acho que tô indo bem né? (vai dando bem)... eu acho que eu tô tratando bem as pessoas que vem né? eu sei recebe eles... sei cunversá cum eles... eh::: vamo

55 pelo campo aí... eles vão me perguntando... eh:.:. e e o que eu posso eu vô informando pra eles falando né?! ... "e o nome daquela ave lá?" "éh arara"... "e aquele... que passarinho é aquele?" "é tal passarinho" (bichos também)... éh:.: qui ... só num... num conheço assim pelo nome... eu conheço pelo o nome de/quando eu conheci pelo aquele

60 nome né? éh::: mas assim... como assim (da coisa aqui) eu sei tudinho o nome deles. (conte-me o dia-a-dia de seu trabalho do senhor, como o senhor começa, que hora que levanta, que o senhor faz até anoitecer?) então... eu levanto cedo... tomo meu mate aqui... naquele fogãozinho ali... cedo só eu... e Deus né?! perante a Deus... aí vô pro

65 manguero tiro meu leite... aí vô trata da tropa... dá ração pra tropa... aí eu pégo o meu animal que eu vô sai nele... aí pégo vô amurcinha... quebra torto, que éh::: uma comida. é o de manhã... é o chá que eles falam.... é comida de sal... se nóis comê um:.: um chá aí Deus me livre (risos)... (pelas) dez horas já tá de barriga lá nas costa... aí eu saio pro

70 campo... aí vô pará rodeo no gado... vê se tem alguma rês abichada... se tem alguma rês doente... então... esse é meu serviço... daí de lá venho... venho ajudá a turma por aqui... que às vezes não tem mais serviço pra mim fazê... senão eu vô... casquiá um animal... fazê um jaravi no animal... casquiá o animal é a pata dele... se pega e levanta a

75 mão dele... limpa por dentro... e aí tem ... um troquês... aí corta o casco do animal.. aí tem ali/tá até lá... ah::: a grosa... aí já grosa bem::: dexa bem certinho... e o jaravi éh:.: o rabo do animal... então cê vai tirá aquele 
mundo de né? mundo de cabelo que fica... é mesma coisa que cortá cabelo... (risos) faz tudo isso... faz isso só quando cresce... é mesma

80 coisa do cabelo... é a mesma... é a mesma coisa da unha nossa... quando cresce nóis tem que cortá porque senão ela vai ficando suja né? éh... fica aquela ( )... tem gente que... não luta com o nosso serviço aqui... como no meu serviço aqui... éh:..... mexe por aqui... e se qualquer coisinha... mexe com uma graxa... a unha já fica na merda... já suja por

85 baixo né? então aqui quando teve uma reunião com nóis aí... então né? tem que te/andá bem limpo né? aqui eu não posso andá muito limpo por que eu mexo cum/cedo vaca veia tá cagando ne mim... pisando bosta... não posso aí né? eu não posso saí de lá tomá banho... troca de roupa... porque que eu vô/como é que eu vô güentá pagá lavadeira... trinta reais

90 por mês... porque eu mando... eu gosto de... que as minha coisa seja bem limpinha né? mando lavá... éh pago... lavadeira... (gosto) tudo passadinho... agora... comê eu como aí no... no ... hotel... éh! gosto dessa vida... porque na cidade num é... eu não güento ficá na cidade... porque na cidade tem que tê dinheiro né? e eu quando võ pra cidade...

95 eu tenho que ta... eu tenho que tê o meu dinheiro... acabô o meu dinheiro/acabô eu também já? éh::: (porque)...gasta (com um mundo de coisa) a gente vai faze/eu paro na casa de um irmão meu... e lá eu tenho que fazê compra... as vez dá dinheiro pra ele (porque) ele também trabalha né?... então eu ajudo (na casa dele)... então pra mim... eu vô na

100 cidade eu paro lá dois... três dia e vô imbora... todo mês eu vô né? aqui a vida é mais tranqüila... dorme tranqüilo... na cidade a gente não dorme muito tranqüilo não? trabalha mui/trabalhei na cidade não gostei... aqui éh/eu ando no campo... vê criação... é parte que eu adoro mais... mexer com os animais... amansá bem mansinho eles né? amansá os animais...

105 quando cheguei aqui essa tropa era tudo novo... era MANsinho de... de lombo... tem uns que qué pulá... mas ( ) só que...é que não sobra dinheiro né? e quando eu... - - então como nóis tava falando negócio de casamento - - depois que eu separei da minha mulher... eu tinha que/eu não dava pensão pros meus filho... mas eu fazia crediário pra eles né?

110 comprava ropa... tirava no/coisa prá pagar por mês... porque tirá dinheiro pra paga tudo... três criança pra vesti aí e carçá num é fácil né? pagá mercado pra eles... e sempre que encontrava com a gente qué dinheiro... eles não qué nem sabe se tem ou não... da donde que vai tirá... mas qué ... éh::.: agora não... graças a Deus tão tudo trabalhando...

115 a menina casô também... já tão tudo adulto... um tá com/o mais velho tá com vinte e um anos...(o seu convívio com a vizinhança aqui da fazenda é bom?) bom... bom... tudo são meus amigo... são tudinho... num tenho... rixa com ninguém por aqui né? garanto que eu chegá numa fazenda dessa aqui... a gente é bem recebido... qualquer fazenda que eu trabalhei... eu chegá eu sô bem recebido... porque nunca briguei com 
ninguém né? nunca saí de mal com ninguém... então se num vai dá certo aquele um/negócio se pega pede a conta e vai embora... pra num ficá intrigando com os outros... vai embora... então... briga num dá camisa pra ninguém... então a gente faz isso aí... bom no meu pensar... 125 tem uns que não... tem... uns que...: num qué nem saber... briga... faz 0 pisero na fazenda... aqui é tudo muito bom... bom... tudo mundo trata um cum o outro brincando... num... num... manhece ninguém brabo com ninguém.... desde a hora que a gente se levanta cedo aqui um brincando com o outro... tirando sarro e vai indo... é até de noite... eles

130 vão fazê o serviço deles ali... eu pego vô fazê o meu... as vezes eles vão me ajudá também no campo... eles me ajudam... as vezes tá apertado aí eu tenho que curá uma rês aí... sozinho é ruim da gente curá... esses dia tive que curá uma rês sozinho... porque eles num pudiam me ajudá e ela tava bichada e... tive que laçá ela sozinho e curá.... só que se não

135 tiver prática num... num... faiz esse aí... (o senhor tem algum medo?) medo a gente tem medo... eu tenho medo assim de/é uma coisa que é - como se fala éh - - é de assombração eu tenho medo também... eu nunca vi assombração... assim não... mas eu acredito... eu já vi o tal de lubisomem... eu encontrei cum ele... isso eu era guri... era gurizão...

140 porque... nóis ia pro baile - - antigamente polícia corria atráis de nóis no baile - - então eu cheguei numa fazenda... trabaiava aqui perto de Rio Verde... aí fui falei pra mãe "vô pro baile" "quê se vai fazê guri?" "ah... vô lá mãe... vó dá uma olhada no baile... ( ) vô arrumá uma namorada... né? gosto de dança" aí fui pra lá... aí nóis fomos entre lote de gurizada...

145 foi dois irmão meu e... e um colega nosso... e cheguemo lá... daí... era uma casa de uma muierada lá... e lá num podia ficá de menor de jeito nenhum... então ficava um sondando - - é tempo da patrulha né? do quartel - - que ela que escurraçava nóis e a polícia... aí chegô a patrulha nóis currimo na casa da... da... da dona lá do baile... mas nóis num

150 conhecia a dona direito... nóis fiquemo escondido embaixo da mesa e a patrulha fazendo a revista por lá achou nóis lá embaixo da mesa... ah... já saiu pega num pega.. nóis era... naquele tempo era magrinho curria ( ) aí desci passei um córgo que até chama até... córgo João Guia... aí ele não pôde com nóis ele não quis molhá a botina dele... ele me largô ali...

155 mas ele ia pega num pega na coisa da minha camisa... eu sentia a mão dele passá (risos) eu falei se chegá de roda na frente desse homem (ele vai) ( ) aí passei o córgo ele largou de mim... foi logo que tava formando a nova Aquidauana, num tinha casa nenhuma na chegada daqui pra lá... a senhora conhece ali a nova Aquidauana né? num tinha nenhuma... era 160 até um... quando ia com boiada... então saia ali fizeram um boiadero ia saí lá na boiadera mesmo éh... então eu... o luar tava claro... eu extraviei dus companheiro... falei 'se eu volta pra lá essa turma vai me pegá ainda... eu vô embora pra casa" aí eu ia indo na estrada e de longe eu 
vi... tava o luar claro... vi aquele tareco preto que vem vindo (eu falei 165 “ih:.: ai..ai..ai..") já pra tráis... já era uma metade grande pra mim vortá né? falei "pra mim vortá pra tráis num dá" lá vai eu pra frente... aí eu parei uma distância... parei fiquei meio de juelho... de olhá ele... vô vê que bicho que vem vindo aí... e ele veio vindo... mas ele é bem feio mesmo... aquele bicho tá loco... ele chegô uma dist/acho que ele nem

170 me viu direito... porque eu tava/ele de certo vinha de cabeça baixa... sei lá eu... que vem... vem molengão... andando... tudo mole... mole... e eu falei... "daqui eu arranco... eu passo perto desse bicho e ele não vai vê que eu vô correndo daqui pra lá... né? ele vai pensá que/creio que passo perto dele" daqui eu arranquei meus Deus do céu... passei correndo 175 muito duro perto desse bicho... e ele é um bichão curtão assim e alto assim... pel:.: (pele) é um preto pel/ele é peludo... ele é um bicho preto... que a oreia dele... ele vai mexendo até... e a mão... e os cutuvelo dele que é... é um bicho feio demais... cheguei é muito assustado lá... lá na chácara... em casa... mas aqui eu dormo sozinho... mas num penso em

180 nada... penso em Deus... benzo meu corpo e deito e... dormo tranqüilo... sô feliz... bem feliz... graças a Deus... até... até agora tô bem feliz aqui... é que tando bem de saúde.... a felicidade que... que eu acho é eu tando bom de saúde e trabalhando... esse aí é minha felicidade... se eu ficá doente meu Deus do céu... então esse já aí... esse aí... já... já fui

185 quebrado umas três veiz... quebrei quando era criança... quebrei aqui trabalhando na... na Olho D'água... na fazenda aqui... era foi dono dessa terra aqui... dono da Santa Maria... trabalhei aqui três anos na... na Olho D’água... então... então... é minha felicidade é eu tê saúde e boas amizades... né? como... como eu... eu me sinto bem aqui porque desde 190 que eu cheguei aqui acho que todo mundo gostou de mim... éh... éh... porque... pelo jeito de eu tratá eles... eu... eu... num chego muito... timidez cum eles... num faço ( ) num respondo pra eles... cum/num faço isso... então o que eles falá pra mim... pra mim tá tudo bem... éh:.: éh::: isso aí que to/porque... se eu sô um ruim... um cara... um funcionário

195 ruim... então eu se eu i pra quela outra fazenda ali... eles vão ligá pra cá... tirá a saber o quê... o quê que eu era... o quê que eu sô... se eu sô um peão bom... se eu sô um peão ruim... as veiz o peão é bom... mas... ele é... ele é ruim né? então aí/dali aquele carinha já num tem (as veiz)... então... pra mim é importante... pra mim é importante... importante pra

200 fazenda né? éh... eu comecei a mexe com o negócio de turismo aí... i é importante pra fazenda né?! ... e é importante pra mim também porque... que eu fico mexendo cum eles e eu quero que a pessoa então... ele sai... ele sai daqui contente... sai sastisfeito... né? nóis trata bem eles... eu sô... BEM importante aqui na coisa... porque... pelo tipo que a turma

205 fala pra mim né? que eu quando cheguei aqui a tropa era tudo bagunçada... já tem... já tem aí... já até criança mesmo anda no cavalo 
aí que era... era um cavalo brabo né? pulava... mas é porque eles provocavam o cavalo pra faze/então se provoca ele pula mesmo... eles acustumam... eles vai acostumando cum aquela que a gente dão um

210 jeito de lidá com ele... ele sai aí... ele vai pastando cum o turista... o turista fica... "oh:.: deixa ele... coitado deixa ele pasta" (risos)... então é importante éh::: éh... éh importante tê paciência pra mim... que o animal também é burro... né? se ele fosse inteligente também... que tem animal que ele sabe... tem animal que ele é delicado... você sabe o que é

215 delicado? É a mesma coisa que uma pessoa delicada... ele num qué...tratamento ruim... éh:.: num qué... tem um cavalo que eu encilho aí... um todo dia... aquele eu num ponho turista porque ele... ele já é um cavalo véio e num tem jeito de tira/se a gente grita cum ele... daí meu Deus do céu já... pode... já... já contrariou ele... ele já num qué dexá pô

220 mais o freio nele... i vira um trem... se dexá ele até põe a mão na cabeça da gente... tudo isso ele qué fazê... então tem que tratá ele com carinho... eu pus o nome dele de "moda"... eu... eu apriquei uma injeção nele... apelido dele... nome dele de "moda" - - que ele saiu uma ferida brava - - eh pra nóis aqui no Pantanal... é ferida da moda... aí eu pus o

225 nome de "moda" nele... (e com os patrões como é o seu relacionamento?) aqui eu conversei... eu não converso quase com eles... sabe... eles chegam aí e eu fico por aqui... até ele falô com o rapaiz aí... que eu sô muito quieto... né? falei "mas claro... eu tô no meu lugar... eu não posso tá indo lá... né?" I pricurá ele por aí e conversar o

230 quê? então... não... eu converso assim com o nosso superior aqui... né? só com o gerente... é com ele... né? porque ele conversa com eles... né? então a gente tem que saber o lugar da gente... como peão... e nóis... eu sei o meu lugar... então... é difícil... aí... esses dias que ele cunversou comigo ( ) "é oh... (...) faz esse serviço aqui pra mim" faço né? tô aqui

235 pra fazê o serviço... fala pra ele... aí eu converso com eles... aí tinha... tinha algum que é teimoso qué que faiz... aí tem que fazê... né? nem que dá mal... mas tem que fazê... porque... aqui às vezes escuta... aqui faiz... até agora (só trata) agora... num:.: falaram nada sobre isso aí... o serviço que eles manda eu fazê é serviço certo.... né? aí é certo... então

240 num tem de eu falá nada pra eles... "não... eu num vô fazê ou vamo fazê diferente né?"... então... éh isso aí... que é bem importante pra gente isso aí... aí... combiná... porque se... se a gente vai fazê o que eles mandam você fazê... um serviço... então o peão já num qué fazê aquele serviço... porque num qué trabalha... né? ele qué... ele qué sê um cara...

245 ruim... então ele num qué fazê aquele... ele não qué sê mandado... eu nunca achei ruim... até uma criança se for um superior nosso... manda nóis aí eu atendo ele... porque ele tá mandando em nóis... ele manda fazê um serviço aí nóis vamo fazê... ué? porque ele tá na gerência... né? ele tá comandando (tudo aí)... então a gente tem que sê assim... tem 
250 gente que já num gosta disso aí... porque às vezes sai/aqui como... aqui é vários... entra um sai... sai aquele... chega outro... outro gerente né? e agora vai... vai vim um gerente mesmo... agora eu num conheço o homem... às vezes a gente num se dá com aquela pessoa... então... às vezes ele num se dá com a gente... por causa disso que eu saí de lá...

255 da... da... Caimã... (num dá nada) num adianta criá caso.... então... vai embora... vai... tem muitas... éh... muitas fazendas pra trabalha... nunca fartô serviço pra mim... sempre eu trato do jeito de/vô pra/às vezes o patrão fala assim "oh::: tal dia eu quero que se tá na fazenda' tar dia tô lá... só se num ti/num achar uma condução... um... ou marcá um horário

260 comigo... 'tar hora te pego" eh... ele pode chegá... éh... atrasado... mas ele não espera eu não... a primeira vez que eu saí da... da... da MirandaEstância... que eu/da Caimã... teve média aí que eu parei... que num combinava mesmo.... tava cum minha mulher lá... e ela que... ela trabalhava... cuidava da... da sede... né? então o patrão era muito

265 nojento... então ele num queria que... se a gente falasse alguma coisa... ele falava "não... isso num dá certo"... então... então eu falei..."então o senhor pega o quê... as coisas do senhor... a fazenda é do senhor... e eu num vô cuidá da terra do senhor desse jeito não... aí nóis num vai combiná então... o senhor mi acerta minha conta que eu vô imbora" levei

270 um mês... ( ) trabalhei um mês... nunca tinha trabalhado assim... trabalhei um mês numa fazenda... mesma coisa que tivesse trabalhado um ano perto dele... Deus me livre.... em outros lugares eu fui pra outra fazenda aí trabalhei um ano e nove meses... aí o fazendero... bom patrão... bom MESmo... aí ele vendeu a fazenda... aí eu saí... saí da/aí

275 fui pra lá pra uma chácra dele... fiquei lá... ele ficou enrolando naquele tempo em que o Collor entrô meteu a mão no dinheiro dele... aí ele num comprou mais fazenda e até hoje ele não comprou mais fazenda dele de novo e ele fico escoiendo... escoiendo... porque naquele tempo o juro era bom... o dinheiro era bom... né? o juro caía quê... era tempo do

280 Sarney... parece... era o Sarney... então ele achô que... quando ele assustô o Collor meteu a mão lá i... limpô o dinheiro dele comprá fazenda.... aí saí de lá vim pra/fiquei morando em Aquidauana em casa alugada... aí fui viajá... aí desci cum gado na estrada mas num gostei disso aí também não... porque eu não adaptei com esse serviço de 285 viagem... que a gente pega muito companheiro ruim... se passa num... num... num ... numa cidadezinha... num... como fala... numa cidade aí... às vezes... o condutor compra uma pinga... ele já pega outra pinga aí... já provoca a gente... então isso num gostei... né? isso pra mim num adaptei... aqui vô fazê quatro mês... vim agora há pouco... eu vim em

290 três mesmo... eu vim com a... a R. ... senhora conhece a R.? a R. que eu vim...ela é diarista aqui... a gente veio pegá uns porco aí... eu fique uns quatro dia diaristando com ela aqui... aí... aí que surgiu essa vaga 
pra mim aqui... né? aí eu fiquei aqui... aí o patrão chegô e o N. falô com ele sobre mim... né? aí ele pegô eu... pra trabalha... então eu falei... 295 vamo indo... vô experimentá... vô vê se... vê como que vai... se num dé certo... a gente vai embora... né? aí a $\mathrm{R}$. voltô de novo... achô eu aqui (risos) a gente já foi trabalha junto de novo... 
ANEXO 6 - DEPOIMENTO 


\section{D4 - HISTÓRIA DE VIDA DO SR. A.}

Idade; 53 anos

Residência: Fazenda Santa Emilia - Pantanal

Duração da gravação: 50 min

Data: 19/06/2004

Éh:... eu vô contá que eu sô o A., né? tenho cinqüenta e três anos... eu fui... nasci e me criei no Pantanal... i:.. desde pequeno eu... passei a:: começá estudá... logo que eu me entendi por gente...né? comecei estudá... aí eu num levei a sério o estudo... meus pai me mandô... pra... pra fazenda... me entregô prum tio meu... que era pra mim aprender o trabalho de dia-a-dia no campo... fui aprendê puxá enxada... fui aprendê também... roçá com foice... éh:: arrancá toco com enxadão... pá ( ) antigamente num existia máquina de estera... num existia trator... essas coisa... era na mão mesmo que a gente (destocava) campo aí... pra

10 formá pasto né? então... eu fui aprendê fazê esse tipo de trabalho porque eu num queria estudo... éh... o objetivo era... trabalhá assim... eu nunca me importei pra estudo... depois por/dos meus pais... eu comecei a estudá mais... mais a culpa foi minha mesmo né? porque eu queria aprender trabalhá e aprender... né? então aí eu comecei com

15 ferramenta... aí passei muntá a cavalo... meu tio era muito rígido então... (hoje) a primera vêis num (toco)... muntei... caí... ele me deu um (laçaço) fez eu muntá de novo - - que era rígido antigamente... a coisa era diferente mesmo... do que vê hoje... né?- - mais então... amuntei... aí foi ino... após uma semana já comecei pará em cima do lombo do animal...

20 foi ino... foi ino... foi ino... que eu gostei... né? e aí eu comecei na lida de campo... que foi ino e foi ( )... aí eu fui... pra... Nhecolândia/que $0 . .$. finado R./lá eu cabei de me criá... lá com eles... né? que eles me adoravam muito... porque... toda vida eu fui o:.. um menino assim... bem educado né? eh::. eu fui criado junto cum eles... lá na lida de campo...

25 único serviço que eu sabia fazê era puxá enxada... foice... machado... fazê cerca... fazê manguero... essas coisa... antes deu casá... eu sabia fazê... né? aí... então fui trabalhano... até... servi o quartel... no quartel eu fui convidado pelo/um cidadão... que ele era major do exército... ele... fui convidado pelo ( ) que ele ia ser transferido pru Rio de Janeiro...

30 então ele... ele gostou demais que eu era (ordenância) dele né? no quartel... aí eu fui convidado pra í com ele pra lá... que ele ia me dá tudo... roupa... carçado... alimentação... quarto... eu ia ficá como se fosse um filho dele né? então eu... num quis... eu falei "eu vô voltá pru Pantanal... que ali é meu lugar" e retornei pru Pantanal depois do 
35 exército... dei baixa e continuei a vida no campo de novo... de campero... aí levei uma (rodada) se quebrei tudo... quase morri... foi/fiquei vinte e quatro hora desacordado... essa é uma das dificuldade e o perigo que a/o campero passa... igual... tem o Seu $R$. aqui... que trabalha conosco aqui... que toma conta do gado... então ele éh:.. o

40 trab... o trabalho dele é arriscado... que no momento que ele tá correndo atrás duma (vaca) ele pode levá uma rodada... sozinho... se quebrá ou enganchá no (arreio) sair dipindurado sozinho... aí vai... vai a morte... né? í::. aí depois... eu sarei... voltei de novo a trabalhá... nos primeiro dia que eu comecei de novo a trabalha... levei otra rodada de novo... aí eu

45 falei "bom... essa chega pra mim" aí eu peguei e vendi minha traia de arreio... vendi tudo... e fui trabalhá... fazê cerca... tirá poste... abandonei a profissão de campero... aí... foi quando eu conheci essa minha esposa... que eu vô fazê trinta ano de casado né? éh:.. aí o meu sogro - casei... aí meu sogro me levô pra Campo Grande... queu num tinha

50 profissão ainda - - (ele falô)/que meu sogro era mestre de obra em Campo Grande... ele foi me ensiná trabalhá de pedrero... aprendi... graças a Deus... né? agradeço a ele... né? aprendi a trabalhá de pedrero... fiquei... oito ano dentro de Campo Grande... morano... abandonei a fazenda... só que eu num esquecia... sabe porquê? a gente

55 se cria aqui... num tem jeito de você saí daqui e falá "eu nunca mais vô vorta" aí... saí de lá... voltei pra Aquidauana... fui aprendê trabalha cum maquinário... voltei pru Pantanal trabalhá... e tô até hoje... só que aí já passei a trabalha com maquinário... já era pedrero... né? já... já tinha profissão boa... já né? já era otra pessoa... já... só que o estudo mesmo 60 nunca me importei... com ele né? ih:.. aí fui trabalhano... com maquinário... fui ino... aí... larguei de maquinário... fui pra:... Fazenda Rio Negro - - que hoje lá é uma pousada... né?- - fui pra lá de pedrero... aí passei pra empresa pra trabalhá de... guia turismo... pra aprende... né? aí lá trabalhei dois anos de guia turístico lá... ih:.:. aí fui convidado aqui

65 na pousada... pra vim trabalhá também como guia turismo... vim pra cá... tô hoje com dois anos também... in:: o que eu tenho pra falá é que eu num desprezo o Pantanal em (hipótese) nenhuma... porque eu tenho minha casa na cidade mas eu num desprezo o Pantanal... de jeito nenhum... porque aqui eu moro... convivo com a minha esposa... tenho

70 uma convivência boa... nunca briguei com a minha esposa... nunca tivemo discussão... tenho cinco filhos... éh:: desses... quatro já casados... tem a filha que é a caçula... que tá com dezesseis anos e tá estudano... na cidade... a otra minha filha... ih:.. meus genros... tudo... estimo eles que são trabalhador também... inclusive um tá aqui que é o

75 D. ... né? éh... o D. é meu genro eh aquela que trabalha junto com aquela baxinha... aquela pessoa... éh... aquela otra éh a... éh a minha filha... então... eu vivo muito contente aqui dentro da pousada... e fora os 
risco... também que eu passei antes de... (disso) passei muito risco com onça... né? éh:.: viajando à noite... cavalo pulá comigo... me derrubá... e 80 eu ficá de a pé no meio de onça... passá aquele/e então eu... pra... pra... pra onde eu cheguei hoje... eu passei por muita dificuldade dentro do Pantanal... que antigamente era muito difícil... pra... pru senhores vê... antigamente não existia condução... a condução nossa no Pantanal era carreta de boi que era (cangado)... do Pantanal a Aquidauana nóis

85 gastava uma semana viajando.... éh:: naquele batidão... devagazinho... então era uma semana de viagem pra ir já... ia base de:: oito... dez carreta em (cordoadas)... ia fazê a compra... pra... passá o ano.... era compra de ano... então... eles gastava semana enjoava de andá em cima da carreta ía de a pé... burro de carga... ou ( ) aí montava de

90 novo... í:... só água naquele mundo... num existia trator... o primero trator que existiu... dentro du Pantanal foi o trator du O. R. um tratorzinho piqueno... du tamanho desse que nóis temo aí... foi o primero trator que nóis vimo no Pantanal... pra nóis foi um... ( )... agora... né? nóis já temo condução aqui no Pantanal... né? a gente gostô muito...

95 né? então... foi... éh:.: essa aí que... veio a chegá até hoje o (doto)... aquele sofrimento que a gente passô... sofrimento:.:: assim no modo de dizê que era difícil... né? mais só que:.. também era gostoso porque a gente aprendia muito... que hoje... do jeito que eu tô... eu posso falá... que eu conheço o Pantanal... porque eu nasci e me criei dentro dele e 100 sei conviver com vários fazendero... que são grande amigo meu - - fui gerente de fazenda... fui capataz de campo - - então... de tudo eu já exprementei na minha vida... a fazenda que eu trabalhei foi a::. a fazenda do:: finado do R.... que é onde me criei... né? aí eu trabalhei na:.: na Rio Negro... era fazenda de pecuária ainda... eh:..:. trabalhei 105 também no Paiaguás... também... éh:: duas fazenda lá... tomando conta de (chiqueiro)... trabalhei também pra lá de Cáceres perto da divida da Bolívia... éh:: tomando conta de fazenda também... eh::. aqui perto de Campo Grande... entre Corguinho e:.. Rochedo... eu tomei conta duma fazenda do senhor (D.) L. de R. ... aí no mesmo tempo peguei a otra

110 fazenda dele... ele me entregô também duas fazenda pra mim gerenciá num tempo só... que tem o motorista que ía andá comigo percorrendo as duas... então... eu sô conhecedô nessa parte tudinha... graças a Deus... eu num me arrependo nem um poquinho de sê um pantanero legitimo né? e hoje aqui... ( ) eu trabalhano como guia e responsável pelas... 115 pelos maquinários e carro... né? então... o meu dia-a-dia já clareia eu já tô pensando de dá uma revisão no... no carro... pra podê fazê o passeio... revisão nos barcos também... pra tá tudo em ordem na hora que hóspede chega... tá tudo em dia... então... a gente tem que mexê cedo porque a hora que chega o horário de fazê os passeio... os barco 120 já tá tudo ok... já tá tudo checado... e os carro mesma coisa e os 
motores (estacionário) também... sempre tô funcionano eles... que é pra... na emergência tá tudo em dia... então... são as... as responsabilidade que eu tenho... que eu uso aqui dentro da empresa e com grande carinho... éh:: o que eu sinto do... daqui do Pantanal

125 nosso... queu... queu gosto muito de convivê no dia-a-dia aqui dentro do Pantanal... porque é um lugar gostoso... é um ar puro que a gente respira todos os dias... não é igual um ar da cidade... que ar da cidade já éh uma poluição... né? então aqui eu me sinto muito bem aqui dentro do Pantanal... por causa que a gente foi criado aqui dentro... então... éh:.:.

130 o dia-a-dia com a... com a gerência também queu hoje graças a Deus... nóis tamo muito feliz também com o gerente que nóis temo aqui... com a esposa dele que é a dona T. também... que tá muito feliz junto com eles... e espero que... a gerência vai longe... né? eh:... a gente encara 0 Pantanal assim... no dia-a-dia... cada dia... a gente qué mostrá pros 135 cidadões... que vêm aqui... a gente qué mostrá MAis animais e qué explicá a mais sobre madeira... sobre pranta... sobre... animais... ave... a gente qué expricá tudo esse pros hóspedes que vêm aqui... porque a gente qué sabê a definição dele... né? cada hóspede perguntava pra mim assim "A. que madeira que é aquela lá?" eu sei falá "aquela lá é 140 uma arueira... aquela é uma piúva... aquela lá é um... é uma... pimentera" então... a gente sabe... decifrá as madeira né? e as ave também... a gente sabe decifrá tudinho... outra coisa éh:: éh que aqui o::. o::. a água principalmente - - na cidade - - o pessoal fala assim "é porque você num toma água dos curixu porque (...) tá um perigo de dá 145 um:::. uma febre amarela... dá um::: uma diarréia... alguma coisa" mais é por engano... por engano... porque eu fui criado tomano água de lagoa... né? fui criado... nunca tive... éh:...perante/antes deu í pro exército... nunca senti nem dor de cabeça... nunca... e os remédio no Pantanal sempre é raízes... né? tem a vassorinha... a vassorinha é boa pra:::

150 machucadura... u.:.: (gervão) também... é uma pranta também medicinal também...é boa também pra:: pra ( ) machucadura também... ou aquele capim amargoso também... u::: queima ele e tira aquela cinza dele... se cortô o pé... na perna... põe aquela cinza em cima... amarra... ele é também contra... pra ficá sangrano... é também ele estanca sangue e

155 tem...certo tipo... também pra tosse... né? pra tosse... forte mesmo... é a raiz de:.: ( ) com:.: caraguatá... que é a raiz do jatobá... então é bom até pra::.. pra (pontada) pneumonia também... e a pena de angola também que é propriado pra (pontada) pneumonia também... então... remédio daqui do::: do... do Pantanal mesmo tem VÁrios tipo de remédio... tem 160 remédio depurativo pru sangue também que é (cancorosa)... né? tem vários tipo de remédio aqui no Pantanal nosso... que:.. assim... as vêis no momento... a gente esquece os nome dele... né? (mas o senhor toda vida... sobreviveu, tratando...) toda vida... sempre... porque no 
Pantanal era difícil... né? então as vêis falava "ah! tem o fulano lá... que 165 ele sabe que... que raiz que é bom”.. então a gente ia lá... atrás do:: daquele cidadão que já é mais antigo né? ia lá ele arrumava aquela... aquela garrafada de raiz e entregava... falava "daqui uma semana você pode vir aqui... que você tá são" eh era... certinho... (Certo?) certo... num existia vacina aqui antigamente... num existia isso... era só remédio

170 de mato mesmo... dor de cabeça... essas coisa... num tinha negócio de::: pastilhinha pra tomá... porque tô com dor de cabeça vô tomá um remédio.... não... não existia... era o remédio do mato mesmo... queu pra dor de cabeça - - por exemplo - - tá forte... faz um chá daquela... de:.: fedegoso... fedegoso.... bateu aquilo já... já beleza... então são essas...-

175 - já éh:.... sobre éh... assombração eu ouvi falá muito... já ouvi... muitas pessoa que correro de assombração... latão rolando atrás... couro fazeno baruio... fogo levantano... fogo... pé de arvre caino em outro lugar... só que eu nunca vi... nunca.. eu... andava à noite, viajano... até (pudia dizê) a gente fala que queria vê e era doido pra vê essas coisa... 180 o fogo que levanta... mais nunca conseguia... num sei se é porque a gente é muito confiante a Deus... num sei... pode sê isso também... né? porque nada de... dessas coisa... aparece pra gente - - e... o mais... do... a gente... os pantanero mesmo... (a senhora vê), tem muitos conhecido meu... que hoje ainda trabalha no Pantanal... e eles tão... tem mais 185 saúde do que eu... que eu já passei pela cidade... já comecei negócio de vacina... essas coisa... e conheço gente do Pantanal aí que nunca tomou uma injeção... e num sente uma dor de cabeça... (o que o senhor mais aprecia aqui no... no Pantanal?) aqui... o que eu mais aprecio no Pantanal aqui éh::. vê as paisagem florida e::. convivê 190 com/assim, vendo os bicho... dia-a-dia... veno... veno onça pintada... veno jaguatirica... veno lobinho... veno tudo... então... isso aí que eu aprecio dentro do Pantanal... e:... a devastação também que éh... o pantanero é contra isso também... né? e todos que vêm lá da serra... ( ) vêm de lá... igual aqui o nosso vizinho...que também são uns bom 195 vizinho... né? mais só que já veio... broqueando já tudo nosso Pantanal... matano bicho... porque um correntão daquele mata muito bicho né? éh:.: éh igual... o pessoal que tão desmatano... né?- - por exemplo - - se entra por exemplo um outro fazendero... daqui dos fundo vamo supô... também da serra... qué dizê que aí... aqui a nossa posada

200 aqui... vai ficá num miolo só de mata e o resto desmatado e nóis sendo prejudicado... prejudicado... a...através professora... pelo... pelo seguinte... pelo nosso correntoso mesmo... aí já vem a cinza... a dequada... que já nóis somo bem fraco de peixe... essas coisa... piranha aqui... então... esse ( ) já vai começá escorrê pra dentro do rio e vai

205 acabá com o restinho dos peixe que tem dentro do rio... e.:... a mata também... vai ficá muito pouco prus bicho e eles vão fugi e procurá um 
lugá mais distante e nóis aqui vamo sê prejudicado... porque eles num vão ficá numa área pequena só... éh isso aí... (o senhor pretende mudar de vida? tem algum outro objetivo... futuro... sonho?) óia

210 professora... oh... oh:... u sonho que eu tenho/ah... ah num se/éh.:. que nóis trabalhamo de guia turismo... o sonho que a gente já tá realizano um pedacinho dele... é a música...e eu tenho o sonho ainda deu subi algum dia na vida através da música... porque Deus quiSÉ... eu tenho esse sonho... (e a relação com os vizinhos, como é aqui?) óia

215 professora... aqui a gente... a relação entre os companheiro aqui... nóis somo mesma coisa que... que uma... uma família... somo bem/todo dia nóis arecebe os companheiro... cassuano... brincano... respeitano um ao outro né? respeitano o serviço de cada um... eu sei que é um... um meio de convivência... um entre uma família né? que aqui nóis somo uma

220 família... nóis somo companhero... né? somo uma família mesmo... isso aí que... eu... o C.... nóis tamo com cinco ano de conhecimento... nóis nunca troquemo uma palavra mal... isso aí é muito importante né? que nóis somo... dois irmão de música... ih:... nóis pretende í até o fim da vida... com a música... se Deus quisé... né? e o resto dos companhero 225 também... pra começá... o D. é genro né? já é da família né? a:.. tem a dona $\mathrm{N}$. também que é uma pessoa excelente... que é a cozinhera... né? e tem o L. também... que a gente conhece ele agora pouco mais é um menino muito legal... bom companhero... né? O R. também... que o $\mathrm{R}$. ele é primo-irmão meu né? então a convivência também já éh família

230 já... né? então... O D. que entrô agora também dona (T.) também são umas pessoas maravilhosa... aqui é tudo em harmonia aqui... graças a Deus... né? éh::.. o que eu sinto (o senhor tem algum medo?) éh:.. em relação da saúde... de algum dia... eu num... num poder mais exercê aquele trabalho que eu faço... ah::: ah - - por exemplo - - cantá algum

235 dia... que Deus me livre... eu peço a Deus que nunca aconteça isso de dá um pobrema nas vóis... num podê saí mais uma vóis assim... esse aí... é só esse o medo que eu... que eu sinto.... sô muito feliz professora... muito feliz mesmo... trabalho aqui tudo trabalho que eu faço aqui... eu faço cum carinho... ih:.. através dos carinho... também

240 que eu sinto pelo... pelos... pelos patrão sente pela gente também... a gente sente por eles também... a gente pretende cada vêis fazê o serviço mais melhor ainda que é pra agradá mais nosso patrão... né? ih... os professores também que vêm... as professoras que vêm aqui também...é... todas elas e todos eles também (aqui) adoram... DImais os

245 professores da Universidade e tanto como professores também... professor também de Brasília... nosso visitante também... a gente adora todos os visitantes... que (são) da Argentina aqui... então - - porque meu pai é argentino - - éh:...... ( ) felicidade pra mim... éh:: quando eu tô atendeno um grupo bão... um grupo especial... igual veio... o grupo 
250 aqui... num é por tá na presença deles aqui... é o grupo da... da Argentina...o grupo da Universidade junto... com o grupo da Argentina... são pra mim... esse aí éh:: éh demais né? são esse aí... sinalizado por aí mesmo né? é bom demais ( ) -- que eu tava viajano... éh:.:: sozinho... no estradão... até eu vinha de Aquidauana pra Fazenda Iguaçu... que

255 fica pra cá... aí eu ía cruzando dentro do picadão... picadão que a gente fala... é uma... estrada dentro do/da mata sabe? então eu vinha a cavalo e tava muito escuro e relampiano pra chove... aí no relampiado assim... eu vi que uma onça tava sentada no meio da estrada e o cavalo refugô... e eu tava sem espera/cavalo manso... ele refugô e me jogô... aí eu caí...

260 ainda bem que o cavalo era manso chegô logo adiante ele paro... né? aí eu no escuro lá... foi até que eu achei o cavalo... que tava soprano... fui lá peguei ele de novo... e daí eu cheguei... consegui chegá na fazenda... aí os pessoal lá vieram no otro dia vê ali... ela me seguiu até no portão da fazenda... a onça... até na chegada da fazenda... ela me seguiu... (a

265 onça era grande?) $\operatorname{sim} . . . \operatorname{sim} . .$. era grande... era... éh:.. não... não... não via... ( ) mais depois via a batida... a pegada... e... aqui no correntoso também... eu escapei de ser pego... por três... o casal e o filhote... eu ia desceno sozinho de barco... in::... aí o barco subiu em cima dum toco... eu desci dentro d'água... ergui o barco e quando eu joguei ela rosnou...

270 pertinho de mim... tava a base duns dez metro longe de mim... daí... se eu continuasse... num/ela ia pulá ni mim e ía me pegá por causa que... 0 rio tava muito estreitinho e tava raso... a água tava aqui assim...( ) é uma onça... é pintada... era o casal... casal e um filhote... então... aí eu quase eu pensei... eu vô voltá... de vorta... porque ela vai me pega... quando

275 eu olhei assim ela tinha saído... aí eu escondi atrás da borda do barco... fiquei escondido... abaxado... in::: o filhote veio direto no barco e cherô a borda do barco e eu escondido do otro lado... aí veio a mãe e pai também ali... cherô o barco e eu escondido atráis... eu... falei "hoje daqui eu num... hoje eu tô morto... né?" então... são os perigo que eu já passei

280 no Pantanal... foi esses dois... a cavalo e essa do barco... daqui do correntoso... ( ) num tem aquele... o perigo que (vaga) os funcionário... né? os patrão chega na fazenda... fica por ali... dali a poquinho já vai embora... né? e os funcionário têm que fazê o serviço do dia-a-dia... pra podê mantê obrigação todo dia... né? antigamente tinha os patrão que

285 acompanhava também na ferramenta junto... né? mais era muito difícil... éh:.:. no meio... no... no tempo que eu me lembro... foi uns dois... três patrão só que pegava também junto com a gente na enxada... no machado... na foice... era junto... né? então... qué dizê que eles também... esses que pegam junto... qué dizê que eles tão... tão

290 arriscado também né? de sê picado por uma cobra... pelo um... um inseto ( )... uma onça pulá neles por detráis... né? qué dizê que éh:.. só que num é todos... né? ( ) em cima do barco... dentro do rio... quando 
eles veio aqui... olhano no barco... né? um jacaré... que eu fui (levá) ele (bocanhô)... bocanhô só a espuma... quase que pegô a minha mão... 295 não... num chegô a pegá... pegô a espuma que tava na mão.... éh:.... foi única vêis... é (risos) foi a única vêis... éh:.: o jacaré ali num é assim::: de atacá... esse... ele foi porque a gente era acostumado... pegá piranha e dá pra ele... então ele acho que... aquela espuma era uma piranha... que eu tava dando pra ele... né? por isso que ele bocanhô... que ele - - a

300 gente acostumô dá de comê pra ele ali... né?- - mais num é que ele VEio ataca... né? ele veio pensando que era... alguma comida pra ele... né? então foi o motivo... que ele bocanhô... ( ) tá veno aquele que tá fazeno a cerca ali... que tá de chapéu grande de palha? é o meu filho... que tá fazeno cerca... ele tá de empreitero do dotô $\mathrm{E}$. aí... então ele mesmo

305 quando ele tá em casa... assim... ô pai... conta aí umas estória aí do... do tempo antigo aí pra nóis aí... pai... aí cumeço a contá pra eles... estória... como foi... a vida... como que eu levei... o mundo... que eu... perdi meus pais... eu tava cum... tava cum seis mêis de nascido... ah::.... o... essa estória é meia triste... né? que meu pai matô a minha mãe e

310 suicidô no mesmo... na mesma hora... é... ( ) sim... sim... daí eu fiquei cum... aí eu fiquei triste... cum meus avô... (é só o senhor, ou tinha mais irmãos?) tinha mais o... tem um irmão e uma irmã... a minha irmã... num conheço ela... porque nunca mais eu encontrei cum ela... num sei se ela é viva... (separaram vocês?) éh... éh... o meu irmão...

315 mora em Aquidauana... in:... então eu fiquei... criei cum meus avô... que eles me registraro como filho... né? ih:.: mais graças a Deus... fui bem criado... bem educado por eles... né? só que era feróis por causa que:.: antigamente... os... os antigo era bruto né? era em cima da... da regra... num podia saí fora de jeito nenhum... tinha que:.. se mandasse... fala

320 "você vai lá no bulixo e vorta rapidão... dez minuto... pra você í lá e vortá" se passasse... já... entrava no reio... fui criado assim... mais só que agradeço porque se num/se eles num fizesse assim comigo... que... que será de mim? porque eu era bruto... né? eu era levado... nem o colégio guentô comigo... eu só queria brigá... queria... né? (e os seus

325 filhos... você criou nesse ritmo?) não... meus filho eu já criei assim... éh::. contando pra eles a educação "meus filho... tem que sê assim... assim... assim" - - só que eles - - nunca surrei eles... nunca judiei deles... eles criaram assim... eu dano... assim... expricações... dano conselho... então... eles chegô onde eles tão hoje... os dois são pedreiro... um é

330 carpinteiro... pedrero e fais cerca também... o otro é pedrero e marcenero... né? o otro trabalha no Indubrasil... lá em Campo Grande... os dois é casado... ih:.. as filha também tão/que uma mora em Saloba... pra Miranda e a otra tá aqui... trabalha junto... e a caçula tá junto com a otra lá também... então... o:... ensinamento meu prus meus filhos foi 335 isso... né? você num fais tal coisa que isso num presta... 
companherismo... ajuntamento... isso num leva a ninguém... ( ) tem que te muita paciência... né? então a gente - eu... adoro demais isso aqui... (cinqüenta e três anos, e o senhor está aprendendo a ler) éh... no momento... tô com cinqüenta e trêis ano... que a gente achô uma 340 pessoa que interessô nos ensiná... eu e o C. tamo... tamo na/pegano... teno aula... né? e a dona T. é uma pessoa que... ela tem muita paciência in:.. e tem... e ensina aquilo com carinho pra gente né? só a gente procurá... aprendê... né? a gente procurá aprendê e graças a Deus hoje a gente já tá leno... escreveno um poquinho... devagazinho nóis tamo... 345 né? pra quem num sabia nada... hoje a gente já... já vamo falá que nóis já ganhamo o escritório já... né? Graças a Deus... 